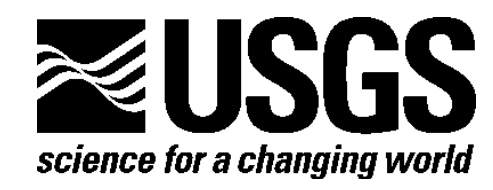

\title{
Seismic Hazard of American Samoa and Neighboring South Pacific Islands-Data, Methods, Parameters, and Results
}

By Mark D. Petersen, Stephen C. Harmsen, Kenneth S. Rukstales, Charles S. Mueller, Daniel E. McNamara, Nicolas Luco, and Melanie Walling

Open-File Report 2012-1087

U.S. Department of the Interior

U.S. Geological Survey 


\section{U.S. Department of the Interior \\ KEN SALAZAR, Secretary}

\section{U.S. Geological Survey \\ Marcia K. McNutt, Director}

U.S. Geological Survey, Reston, Virginia: 2012

For product and ordering information:

World Wide Web: http://www.usgs.gov/pubprod

Telephone: 1-888-ASK-USGS

For more information on the USGS—-the Federal source for science about the Earth, its natural and living resources, natural hazards, and the environment:

World Wide Web: http://www.usgs.gov

Telephone: 1-888-ASK-USGS

Suggested citation:

Petersen, M.D., Harmsen, S.C., Rukstales, K.S., Mueller, C.S., McNamara, D.E., Luco, Nicolas, and Walling, Melanie, 2012, Seismic hazard of American Samoa and neighboring South Pacific Islands-Methods, data, parameters, and results: U.S. Geological Survey Open-File Report 2012-1087, 98 p.

Any use of trade, product, or firm names is for descriptive purposes only and does not imply endorsement by the U.S. Government.

Although this report is in the public domain, permission must be secured from the individual copyright owners to reproduce any copyrighted material contained within this report. 


\section{Contents}

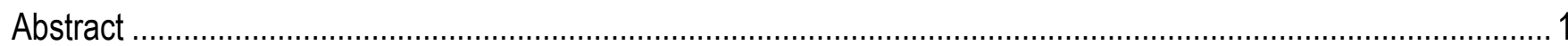

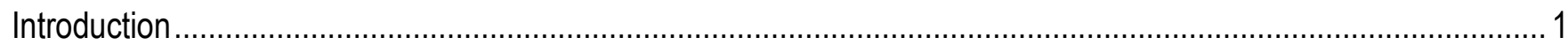

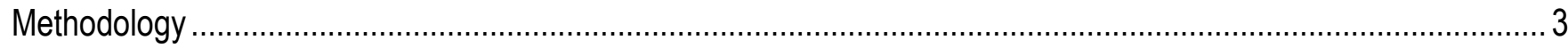

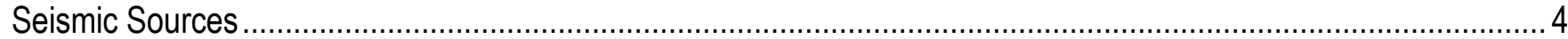

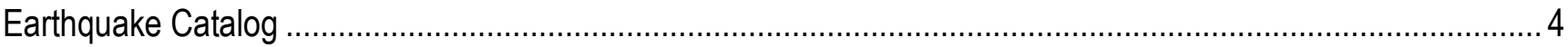

Gridded-Seismicity Background Models ........................................................................................... 5

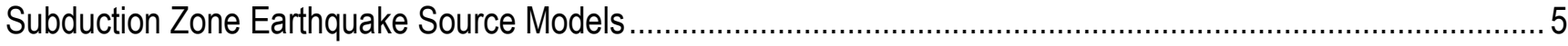

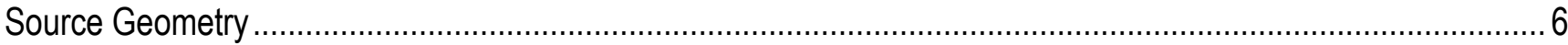

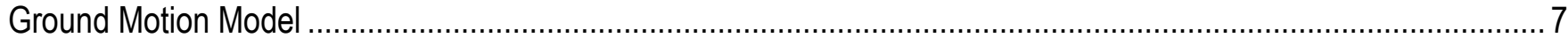

Summary of Current Ground Motion Prediction Equations ……………………………………....................

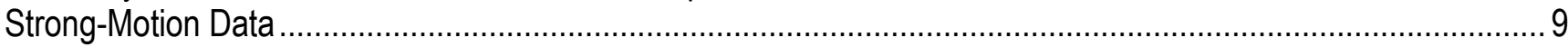

Analysis of Ground Motion Prediction Equations .................................................................................... 11

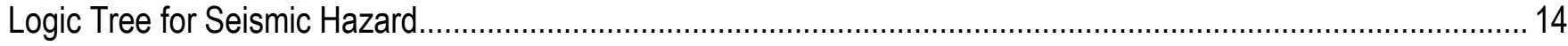

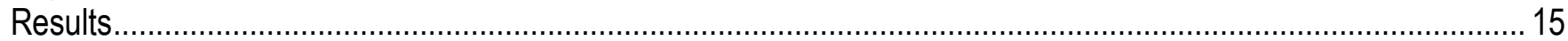

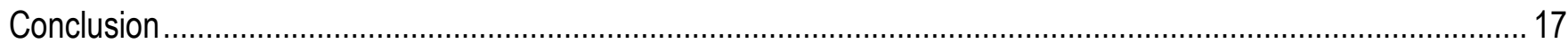

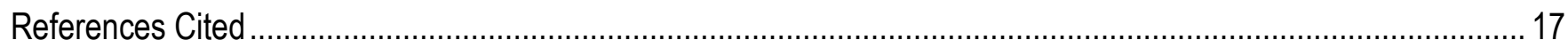

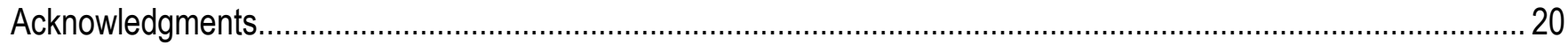

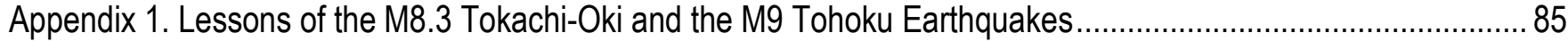

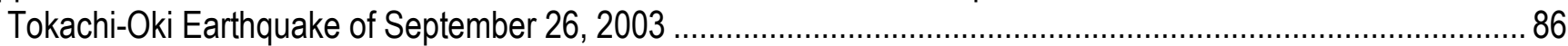

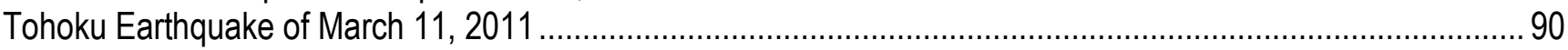

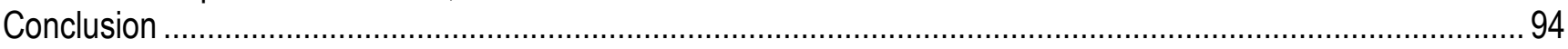

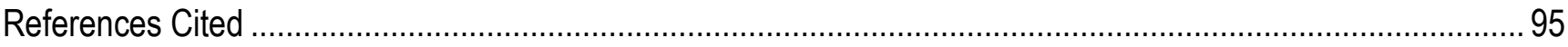

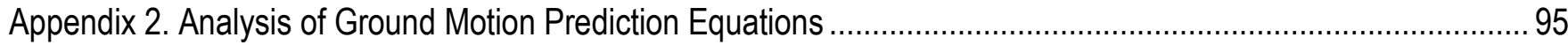

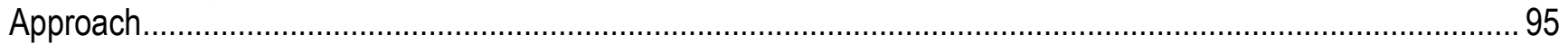

\section{Figures}

1. Map showing faults and large earthquakes $M \geq 7$ since 1900 , depth contours of subducing slab and plate tectonic features and slip rates

2. Map showing $M \geq 5$ earthquakes since 1964 , color-coded by depth and cross sections across the Tonga and New Hebrides (Vanuatu) subducting slabs......................................................................... 22

3. Focal mechanisms from Global Centroid-Moment Tensor Project Bathymetry from GMT ........................... 23

4. Magnitude-frequency plot showing annual rates of earthquakes in the catalog 1900-2010 and 1964-2010 (not declustered) and the declustered catalog.....

5. Magnitude-frequency plot showing cumulative number of earthquakes exceeding each magnitude for different depth levels.

6. Magnitude-frequency distribution for the primary shallow-source models ( $0-50 \mathrm{~km}$ depth) showing the cumulative number of earthquakes exceeding each magnitude ......................................................... 26

7. Magnitude-frequency plot for New Hebrides region showing fits to the observed data for $M \geq$ 7 events since 1900 .

等

8. Magnitude-frequency plot showing the fit to the observed Tonga earthquake data $M>7$ since $1900 \ldots \ldots \ldots . . .28$

9. Map showing location of sources used in constructing the seismic hazard maps ......................................... 29 
10. Plot showing four 1-Hertz Spectral acceleration ground motion prediction equations for M 6.5 and $M 7.5$ earthquakes on the $A$ interface and the $B$ intraplate sources.

11. Plot showing four $5 \mathrm{~Hz}$ Spectral acceleration ground motion prediction equations for $\mathrm{M} 6.5$ and $\mathrm{M} 7.5$ earthquakes on the $A$ interface and the $B$ intraplate sources.

12. Comparison of the Atkinson and Boore (2003) global, Youngs and others (1997), and Zhao and others (2006) intraplate 5-Hertz (Hz) (lower plot) and interface 1- $\mathrm{Hz}$ (upper plot) spectral accelerations.

13. Plot showing three Spectral acceleration ground motion prediction equations (A. $1 \mathrm{Hertz}(\mathrm{Hz})$, B. $5 \mathrm{~Hz}$ ) for an M 7.5 intraplate earthquake as a function of depth.

14. Ground motion prediction equations showing spectral acceleration at 1 second (sec) (1 Hertz ( $\mathrm{Hz})$ ) and $0.2 \mathrm{~s}(5 \mathrm{~Hz})$ spectral acceleration for distances up to $200 \mathrm{~km}$ for the Zhao crustal equations, Zhao intraplate, and NGA-Boore and Atkinson (2008) crustal models.

15. Ground motion prediction equations showing spectral acceleration at 1 second (sec) (1 Hertz ( $\mathrm{Hz})$ ) and $0.2 \mathrm{~s}(5 \mathrm{~Hz})$ spectral acceleration for distances up to $200 \mathrm{~km}$ for the Zhao crustal equations, Zhao intraplate, and NGA-Boore and Atkinson (2008) crustal models.

16. Map showing earthquakes $M>6$ and recording stations used in determining weights applied for the ground motion prediction equations

17. Graph showing the Zhao and others 2006 intraslab ground motion model with Pacific strong motion data for $A, 1 \mathrm{~Hz}$ Spectral acceleration and $B$, Peak horizontal ground acceleration

18. Magnitude distribution versus $A$ distance and $B$ depth. Red circles represent interface events and blue squares represent intraslab events. 38

19. PGA residuals at each station in natural log units. Station Numbers: 1 is ADK, 2 is AFI, 3 is DAV, 4 is GUMO, 5 is HNR, 6 is PET, 7 is RAO, and 8 is TATO

20. Five Hertz residuals at each strong motion station based on natural log units. Station numbers are as follows: 1 is ADK, 2 is AFI, 3 is DAV, 4 is GUMO, 5 is HNR, 6 is PET, 7 is RAO, and 8 is TATO ....

21. One Hertz residuals at each station based on natural log units. Station numbers are as follows: 1 is ADK, 2 is AFI, 3 is DAV, 4 is GUMO, 5 is HNR, 6 is PET, 7 is RAO, and 8 is TATO

22. $A$, correlated residual PGA versus moment magnitude; $B$, uncorrelated or single station residual PGA versus moment magnitude; $C$, uncorrelated or single station residual $5 \mathrm{Hertz}(\mathrm{Hz})$ versus moment magnitude; $D$, uncorrelated or single station residual $1 \mathrm{~Hz}$ versus moment magnitude

23. Average single station residuals versus moment magnitude for $A, P G A ; B, 5 \mathrm{~Hz}$; and $C, 1 \mathrm{~Hz}$.

24. Single station residuals as a function of distance for $A, P G A$ and average single station residuals versus distance for $B, P G A ; C, 5 \mathrm{~Hz}$; and $D, 1 \mathrm{~Hz}$

25. Logic tree for subduction-fault sources. Parameters in this table include some aleatory variability as well as depicted epistemic uncertainty.

26. Seismic hazard contributed by the Tonga and New Hebrides subduction zones 1 Hertz spectral acceleration for 2 percent probability of exceedance in 50 years on a uniform firm rock site condition. Focal mechanisms derived for $\mathrm{M} \geq 7$.

27. Background hazard maps for 5 Hertz Spectral Acceleration 2 percent probability of exceedance in 50 years on firm rock site condition for earthquake sources with depths $A, 0-50$ kilometers $(\mathrm{km})$;

B, 50-100 km; C, 100-200 km; D, 200-750 km.

28. Background hazard maps for 1 Hertz Spectral Acceleration 2 percent probability of exceedance in 50 years on firm rock site condition for earthquake sources with depths $A, 0-50$ kilometers $(\mathrm{km})$; $B, 50-100 \mathrm{~km} ;$ C, 100-200 km; and D, 200-750 km.

29. Hazard map with all sources for 1 -second Spectral Acceleration 10 percent probability of exceedance

in 50 years on firm rock site condition.

30. Hazard map with all sources for 1-Hertz Spectral Acceleration 2-percent probability of exceedance in 50 years on firm rock site condition. 
31. Hazard map with all sources for 5-Hertz Spectral Acceleration 10 percent probability of exceedance in 50 years on firm rock site condition.

32. Hazard map with all sources for 5 -Hertz Spectral Acceleration 2 percent probability of exceedance in 50 years on firm rock site condition.

33. Hazard map with all sources for Peak Horizontal Ground Acceleration with a 10 percent probability of exceedance in 50 years on firm rock site condition

34. Hazard map with all sources for Peak Horizontal Ground Acceleration with a 2 percent probability of exceedance in 50 years on firm rock site condition

35. Deaggregation plots of a site at Pago Pago, American Samoa for 1 second (sec) $(1 \mathrm{Hertz}(\mathrm{Hz}))$ and $0.2 \mathrm{~s}(5 \mathrm{~Hz})$ spectral accelerations.

36. Deaggregation plots of a site at Nuku'alofa, Tonga for 1 second $(\mathrm{sec})(1 \mathrm{Hertz}(\mathrm{Hz}))$ and $0.2 \mathrm{~s}(5 \mathrm{~Hz})$ spectral accelerations

37. Deaggregation plots of a site at Suva, Fiji for 1 second $(\mathrm{sec})(1 \mathrm{Hertz}(\mathrm{Hz}))$ and $0.2 \mathrm{~s}(5 \mathrm{~Hz})$ spectral accelerations

38. Deaggregation plots of a site at Port Vila, Vanuatu for 1 second $(\mathrm{sec})(1 \mathrm{Hertz}(\mathrm{Hz}))$ and $0.2 \mathrm{~s}(5 \mathrm{~Hz})$ spectral accelerations 66

\section{Tables}

1. b-values, maximum magnitudes, and rates of earthquakes applied in the hazard model .........................6 67

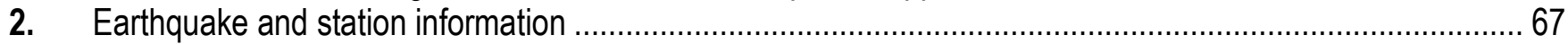

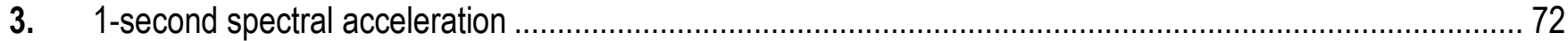

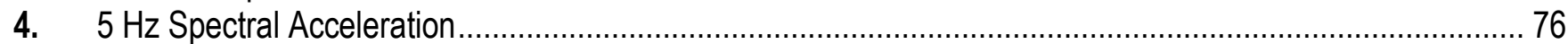

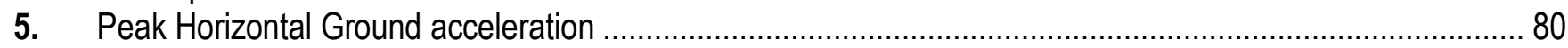

6. Systematic Offset of the Zhao and others (2006) equation for Pacific region data .................................. 84

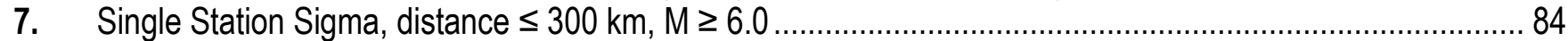

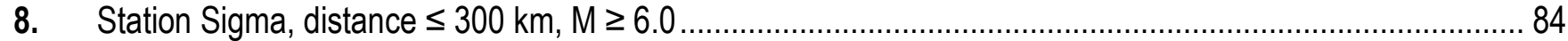

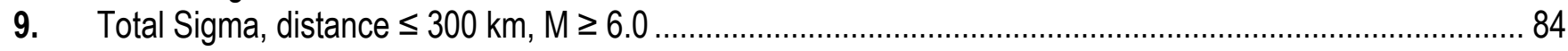




\title{
Seismic Ground Shaking Hazard for American Samoa and Neighboring South Pacific Islands-Data, Methods, Parameters, and Results
}

By Mark D. Petersen, Stephen C. Harmsen, Kenneth S. Rukstales, Charles S. Mueller, Daniel E. McNamara, Nicolas Luco, and Melanie Walling

\begin{abstract}
American Samoa and the neighboring islands of the South Pacific lie near active tectonic-plate boundaries that host many large earthquakes which can result in strong earthquake shaking and tsunamis. To mitigate earthquake risks from future ground shaking, the Federal Emergency Management Agency requested that the U.S. Geological Survey prepare seismic hazard maps that can be applied in building-design criteria. This Open-File Report describes the data, methods, and parameters used to calculate the seismic shaking hazard as well as the output hazard maps, curves, and deaggregation (disaggregation) information needed for building design. Spectral acceleration hazard for 1 Hertz having a 2-percent probability of exceedance on a firm rock site condition (Vs30=760 meters per second) is 0.12 acceleration of gravity ( 1 second, 1 Hertz) and 0.32 acceleration of gravity (0.2 seconds, 5 Hertz) on American Samoa, 0.72 acceleration of gravity (1 Hertz) and 2.54 acceleration of gravity ( 5 Hertz) on Tonga, 0.15 acceleration of gravity (1 Hertz) and 0.55 acceleration of gravity (5 Hertz) on Fiji, and 0.89 acceleration of gravity $(1 \mathrm{Hertz})$ and 2.77 acceleration of gravity $(5 \mathrm{Hertz})$ on the Vanuatu Islands.
\end{abstract}

\section{Introduction}

American Samoa and the adjacent South Pacific islands are located in a region where complex tectonic interactions produce frequent earthquakes on subduction interfaces; within subducting slabs; along the outer rise region of subducting slabs; as well as on numerous fractures, spreading centers, and shear zones distributed across the region. Many of the islands along the Samoa archipelago were formed between 28 and less than 2 million years ago as the Pacific plate moved westward across a stationary hotspot, creating a 485-kilometer $(\mathrm{km})$ long chain of shield volcano islands, seamounts, and atolls (Thornberry-Ehrlich, 2008). High seismicity and geodetic strain-rate observations manifest the current rapid deformation rates across the region (fig. 1; Pelletier and others, 1998; Bird, 2003). These high strains result in frequent large earthquakes; since 1900, $242 \mathrm{M}$ greater than or equal to 7 earthquakes have been recorded, or an average rate of more than two large earthquakes per year.

While most of the historical damage has been caused by earthquake-induced tsunamis, ground motions occasionally reach a level that results in building, contents, or infrastructure damage (for example, 2010 M 7.5 Vanuatu earthquake). This report focuses on shaking hazard, but the source models developed here can also be applied to developing future tsunami, liquefaction, and landslidehazard assessments. For more information on the September 29, 2009 tsunami, we refer the reader to a USGS report by Jaffe and others (2010) on the tsunami inundation limits and a report by the UK 
Earthquake Engineering Field Investigation Team (2010) on resulting damage and loss. Understanding the potential ground-shaking hazard can be useful in mitigating the effects through thoughtful public land-use policy; effective disaster mitigation and response plans; and efficient engineering design standards for buildings, bridges, highways, utilities, etc. These analyses can be used to develop resilient buildings and infrastructure in a cost-effective manner that can save lives and financial resources.

Earthquake shaking models are developed by using historic seismicity data to model earthquake sources as well as by using ground-motion prediction equations (GMPEs, also known as attenuation relations) that describe ground shaking from earthquakes with different magnitudes, styles of faulting, and distances from the earthquake. In this report, we describe the development of seismic source models that are based on historical seismicity rates (obtained from an earthquake catalog) and fault maps. Large subduction interface earthquakes contribute most to the seismic hazard at nearby sites and are welldefined by the seismicity patterns and size distribution of historic earthquakes. However, other earthquake sources can contribute significantly to the seismic hazard, especially at sites located well away from the subduction zones. Most of these other sources are not well known, so we construct "background source models" to account for earthquakes that occur randomly on unmodeled faults (for example, deep earthquakes, spreading centers, and outer-rise earthquakes where the slab cracks due to bending stresses).

To calculate hazard from each of the seismic sources, we consider published GMPEs that relate ground-shaking levels from different sizes and styles of earthquakes (Youngs and others, 1997; Atkinson and Boore, 2003; Zhao and others, 2006; Boore and Atkinson, 2008; Campbell and Bozorgnia, 2008; Chiou and Youngs, 2008). Ground-motion models estimate shaking from earthquakes on the subduction interfaces (interface equations), from deep earthquakes that are thought to be caused by bending stresses as the slab bends downward to descend beneath the adjacent tectonic plate (intraslab or in-slab equations), and shallow crustal earthquakes. We weight the subduction-related models based on how well they fit regional strong-shaking data we collected from seismic stations located across the Pacific Ocean region. This step ensures that the shaking models we apply are appropriate for this region of the South Pacific. We assume that the future shallow crustal earthquakes in this region will have similar ground motions compared to those described in shallow crustal ground motion equations developed for Japan and global earthquakes.

In this report, we describe the development of hazard and design maps that will be provided to building-code committees for their analysis of American Samoa design procedures. The USGS has developed hazard maps over the past 35 years (yr) (for example, Frankel and others, 2002; and Petersen and others, 2008) that are applied in seismic provisions of building codes (for example, Building Seismic Safety Council, 2009). These methodologies are mostly applied in developing this hazard analysis; however, some modifications have been made to account for regional South Pacific tectonics and oceanic terrain. For example, we consider a different weighting of GMPEs and include a shallow crustal model that was not included in the USGS hazard maps. In addition, we incorporate magnitudefrequency distributions based entirely on historic seismicity data since this region is so rich in earthquakes. The study region was expanded beyond American Samoa to include other South Pacific islands because in the past years only a few small-scale seismic hazard maps have been pieced together to make regional maps of this region (for example, the Global Seismic Hazard Assessment Program, GSHAP; Giardini and others, 1999) and because our results show that earthquakes across this area have similar source and ground-shaking characteristics. In this report, we compare our results to the global GSHAP model and a recently developed probabilistic seismic hazard model for Vanuatu (Suckale and Grünthal, 2009). 


\section{Methodology}

For this hazard analysis, we apply the methodology that was used in developing the National Seismic Hazard Maps for the Conterminous United States (Frankel and others, 2002; Petersen and others, 2008). Probabilistic hazard is calculated using three models: (1) random seismic background source models (gridded), (2) subduction zone fault source models, and (3) earthquake ground-shaking models. An earthquake catalog is used to define the random seismic sources and to estimate the rate of large earthquakes on the subduction-zone sources. The resulting random seismic background model accounts for the observation that larger earthquakes occur at or near clusters of previous smaller earthquakes (Frankel, 1995), while the subduction model is based on historic seismicity rates and a geophysically derived 3D geometry of the fault.

The earthquake catalog is constructed by merging regional catalogs developed by different institutions. Duplicate events and manmade events are deleted because seismic hazard models require a declustered earthquake catalog of independent events (foreshocks and aftershocks removed) for calculation of Poissonian (time-independent) earthquake rates. The earthquake rates are sensitive to completeness levels for the catalog; we do not want the results to be biased by network inadequacies. Once we have complete catalog representations, we can calculate regional a- and b-values (defining the activity rate and slope of the magnitude frequency distribution, from Gutenberg and Richter, 1944) by using a maximum likelihood method (Weichert, 1980).

The earthquake catalog is then used to develop random seismic source models that characterize the hazard from earthquakes between about M5.0 and some maximum magnitude determined from paleoseismic information, historical seismicity, or global analogs. Random seismicity-derived background sources account for two types of earthquakes: those that occur off known faults, and moderate-size earthquakes that are not modeled explicitly on faults. Regional zones allow for local variability in seismicity characteristics or plate tectonics and are used to incorporate alternative models of the b-value or maximum magnitude (Mmax). The seismicity from the earthquake catalog $\mathrm{M}$ greater than or equal to 4 is smoothed and gridded using a two-dimensional Gaussian smoothing operator (Frankel, 1995) from which earthquake rates $\left(10^{\mathrm{a}}\right.$ values from the Gutenberg and Richter relationship) are calculated. Next, we calculate the hazard from these gridded-seismicity background sources by applying a truncated-exponential, Gutenberg-Richter magnitude-frequency distribution (Gutenberg and Richter, 1944) using the b-values calculated for each of the zones. Earthquakes smaller than M 6.0 are characterized as point sources at the center of each cell, whereas larger earthquakes are assumed to occur on hypothetical finite vertical or dipping faults centered on the source grid cell. To calculate lengths from a particular magnitude, we precalculate average distances from virtual faults with strike directions uniformly distributed from 0 to $180^{\circ}$ (appendixes B and C in Petersen and others, 2008). The average-distance calculation ensures that no receiver is assigned a biased distance based on an arbitrary draw from a random-number generator. The virtual fault length is based on a subduction-zone earthquake rupture length versus magnitude regression performed by Geomatrix Consultants (1995). The formula is: rupture length $=10^{(\mathrm{M}-4.94) / 1.39}$.

The subduction zone source model is built assuming that future earthquake rates on subduction interface sources will be similar to the past observed seismicity rates. Earthquake-recurrence rates and geometry for subduction faults are based on geologic measurements, geodesy strain rates, and seismicity characteristics. An important consideration in the hazard analysis is estimating the size and frequency of earthquakes that can rupture along the subduction interfaces of the Tonga and New Hebrides zones. We estimate the $a-$ and $b$-values of the magnitude-frequency equation by fitting a Gutenberg-Richter distribution to the historic seismicity. Alternative source models are then constructed for estimating the epistemic uncertainty in the maximum magnitude that is capable of occurring in the zone. This 
epistemic uncertainty is described using a logic-tree analysis that characterizes alternative input models and their weights at each decision point in the analysis. Aleatory variability is considered directly in the seismic hazard code and accounts for random variability in the locations and magnitudes of earthquakes along the subduction zones. Typically, a given parameter in the analysis contains both epistemic uncertainty and aleatory variability components.

The GMPEs relate the source characteristics of the earthquake and propagation path of the seismic waves to the ground motion at a site. The predicted ground motion is typically quantified in terms of a median value and measure of uncertainty, which is a function of magnitude, distance, style of faulting, and other factors. These models assume a lognormal probability density function (aleatory variability) of peak horizontal ground acceleration (or spectral accelerations) that is integrated in the analysis to obtain the probability of exceedance of a particular ground-motion level. In this hazard model, we calculate ground motions from subduction interface sources that are up to 1,000 kilometers $(\mathrm{km})$ from the source and intraslab and shallow crustal earthquake that are up to $200 \mathrm{~km}$ (epicentral distance) from the site. We apply the subduction interface models to account for large (greater than M 7) shallow earthquakes (less than $50 \mathrm{~km}$ depth) on the subducting fault plane and intraslab equations to characterize all other earthquakes. The ground motion alternative models are accounted for in a logic tree framework to account for epistemic uncertainty.

\section{Seismic Sources}

Our seismic source model is composed of two subduction source models with 3D geometry and background source models for different depth layers, tectonic regimes, and maximum magnitudes. Both of these models depend on the earthquake catalog that we produce for this paper. We are not aware of slip-rate data or paleoseismic studies for faults on these South Pacific islands. Therefore, the earthquakes on subduction zone faults and background seismicity are modeled using historic seismicity. This hazard model assumes that earthquakes will continue at the same rate and size distribution as observed over the past century.

\section{Earthquake Catalog}

A new seismicity catalog was compiled for this project from three global source catalogs. The Engdahl and Villaseñor (2002) catalog (EVC) includes earthquakes greater than about magnitude 6.5 since 1900 and about magnitude 5.5 since 1964. A second catalog (PDE) was downloaded from the USGS Earthquake Hazards Program website and includes earthquakes from 1973 through December, 2010 (http://earthquake.usgs.gov/earthquakes/eqarchives/epic/epic_rect.php, "Rectangular Area Search," accessed January 6, 2011). A third catalog (ISC) was downloaded from the International Seismological Centre website and includes earthquakes from 1907 through May, 2008 (http://www.isc.ac.uk/search/bulletin/rectang.html, "On-line Bulletin, Rectangular Selection," accessed July 26, 2010). The three source catalogs were reformatted, concatenated, and sorted chronologically. Moment magnitudes $\left(\mathrm{M}_{\mathrm{w}}\right)$ were either selected directly from original source catalogs or converted from other magnitude types using published relations that account for saturation and other scaling effects; we use Sipkin (2003) to convert body-wave magnitude $\left(\mathrm{m}_{\mathrm{b}}\right)$ to moment magnitude $\left(\mathrm{M}_{\mathrm{w}}\right)$ and bilinear or trilinear approximations to the curves plotted by Utsu (2002) for surface wave magnitude $\left(\mathrm{M}_{\mathrm{s}}\right)$ and local magnitude $\left(\mathrm{M}_{\mathrm{L}}\right)$. Duplicate catalog entries were identified and deleted using the preference order: Engdahl and Villasenor (2002) catalog greater than Preliminary Determiniation of Epicenter catalog, PDE, greater than International Seismic Centre catalog, ISC. For the hazard analysis, foreshocks and aftershocks were identified and deleted using the declustering methodology of Gardner and Knopoff 
(1974). No special declustering treatment was applied for great earthquakes. The Gardner and Knopoff technique only considers earthquakes up to M 8, using a maximum 94-km-radius circular aftershock window. Even though this window is circular, the algorithm deletes aftershocks of aftershocks and will naturally eliminate more earthquakes along the trend of the fault.

The earthquake catalog is shown in figure 2 for earthquakes with $\mathrm{M}$ greater than or equal to 5 color coded by depth. Cross sections show the dips and depths of earthquakes in the Benioff zone. Earthquakes extend down several hundred kilometers along both subducting slabs. Figure 3 shows the moment tensors of the Global Centroid-Moment Tensor Project. Strike-slip, reverse, and normal fault earthquake mechanisms are distributed across the region. The normal fault earthquakes off both trenches are thought to be associated with bending stresses in the outer rise.

Figure 4 shows the annual rate of earthquakes with M greater than 4.0 since 1900 and 1964 as well as the declustered catalogs from the same periods. The earthquakes follow a Gutenberg-Richter magnitude-frequency distribution (Gutenberg and Richter, 1944) between M 5 and the upper magnitudes; for earthquakes with magnitudes less than M 5, the curve bends over — this suggests an incomplete catalog. Therefore, we use M 5.0 since 1964 as our completeness cutoff for the earthquake catalog. Most of the declustering occurs for earthquakes less than M 7. The rates calculated for the 1900 and 1964 catalogs are similar for events greater than M 6.5.

\section{Gridded-Seismicity Background Models}

We use the declustered catalog as the basis for the background source model. The $\mathrm{M}$ greater than or equal to 4 earthquakes since 1964 are smoothed using a $50 \mathrm{~km}$ smoothing kernel and $10^{\mathrm{a}}$ values (which sets the earthquake rate in the Gutenberg and Richter, 1944 relationship) are calculated at grid points spaced 0.1 degree apart in longitude and latitude. We calculate the Gutenberg and Richter bvalues based on the 1900-2010 and 1964-2010 catalogs for several regions and depth intervals (figs. 5 and 6). With one exception, the calculated b-values are generally close to 1.0 for the background and outer rise zones, but we use the calculated b-values in this hazard analysis (table 1). The primary outlier in this b-value analysis is associated with the zone overlying the upper $50 \mathrm{~km}$ of the New Hebrides subduction zone, where the $\mathrm{b}$ value is about 0.58 . We use the calculated $\mathrm{a}$ - and $\mathrm{b}$-values to produce $\mathrm{a}$ magnitude-frequency distribution from M 5.0 to Mmax. The seismicity analysis of Sukale and Grünthal (2009) indicates a b-value of 0.71 , which is also lower than observed for most similar tectonic environments. Sukale and Grünthal used a different declustering algorithm and different completeness times, and these differences would account for some of the differences between their b-value calculations and ours.

\section{Subduction Zone Earthquake Source Models}

Subduction-interface earthquakes $\mathrm{M}$ greater than or equal to 7 are modeled as rupturing from $10 \mathrm{~km}$ down to $50 \mathrm{~km}$ depth. Deeper earthquakes on the Wadati-Benioff zone are modeled using a Gutenberg and Richter (1944) magnitude-frequency distribution with the smoothed rate of earthquakes and a calculated b-value. Figure 7 shows a magnitude-frequency plot of the 32 shallow $\mathrm{M}$ greater than or equal to 7 earthquakes associated with the New Hebrides zone. The b-value of 0.58 that was calculated from the $\mathrm{M}$ greater than or equal to 4 earthquakes does not fit the rates of the larger earthquakes. Analysis of figure 7 indicates that a b-value of 1.0 better predicts earthquakes $\mathrm{M}$ greater than or equal to 7 events in the model. Figure 8 shows a magnitude-frequency plot of the $22 \mathrm{M}$ greater than or equal to 7 earthquakes associated with the Tonga subduction zone. The b-value calculated for $\mathrm{M}$ greater than or equal to 4 earthquakes in this region is consistent with the b-values calculated from $\mathrm{M}$ greater than or equal to 7 earthquakes within the Tonga zone, so we use the calculated b-value of 
0.87 for the entire range of earthquakes from M 5.0 to 7.0. The slip rate varies along the strike of the New Hebrides and Tonga subduction zones, so we considered whether or not to allow for variable rates of $\mathrm{M}$ greater than or equal to 7 events. Figure 1 shows $M$ greater than or equal to 7 earthquakes, and the observed rate of earthquakes does not appear to be correlated with the slip-rate variability. For example, of the $32 \mathrm{M}$ greater than or equal to 7 events along the New Hebrides zone, 17 events occurred along the northern half of the zone and 15 along the southern half of the zone, even though the slip rate varies significantly along the strike. Of the $22 \mathrm{M}$ greater than or equal to 7 earthquakes along the Tonga zone, 12 events occurred in the northern half and 12 events in the southern half of the zone, even though slip rates displayed in figure 1 in the northern portion of the zone are more than double slip rates in the southern portion of the zone. Moreover, the seismicity appears to be located uniformly along the length of these zones, although the Tonga zone exhibits less uniformity and contains two clusters of large earthquakes. Therefore, for this assessment, we assume that the seismicity rate does not vary along the strike of the subduction zone and is consistent with the historic rate of earthquakes along the entire zone.

Earthquakes occurring prior to modern seismic instrumentation were sometimes recorded from written observations of tsunamis or earthquake effects. Okal and others (2004) suggest that three large earthquakes in the early twentieth century on the Tonga-Kermadec arc system were thought to have maximum magnitudes between 8.4 and 8.7. They suggest that more recent moment estimates of these events led to the perception that maximum magnitude for earthquakes on this subduction zone would have moment of $2.5 \times 10^{28}$ dyne-centimeter, which is consistent with a lower Mw 8.2 earthquake. Okal and others (2004) interpreted regional tsunami data from the November 17, 1865, earthquake as originating from a large earthquake on the Tonga-Kermadec arc system with moment of $4 \times 10^{28}$, which is consistent with Mw 8.4. This evidence in combination with the December, 2004 M 9.1 earthquake on the Sumatra subduction zone and the March 11, 2011, M 9.0 Tohoku-Oki earthquake near Sendai on the Japan subduction zone (both events were greater in size than anticipated) were influential in assessing the alternative maximum magnitude models that we applied to these subduction zones. We have assigned a weight of $1 / 2$ to the model in which these earthquakes occur with magnitude up to 8.5 and have assigned a weight of $1 / 2$ to the model in which these earthquakes are capable of rupturing in earthquakes up to magnitude 9.0 on the subduction interface. For all other zones, we typically have considered the largest historic magnitude with an additional 0 to 0.2 magnitude units to account for the possibility that we have not observed the largest potential earthquake during the past century. Table 1 shows the parameters applied in our model, including the largest observed earthquakes in each zone as well as the maximum magnitudes applied in the model.

\section{Source Geometry}

Figure 9 shows the source zones considered for our model. We separated out 6 zones in the model: (1) Tonga subduction interface, (2) New Hebrides subduction interface, (3) Tonga outer rise, (4) New Hebrides outer rise, (5) the Fiji zone that encompasses much of the back-arc spreading and fracture zones in the Fiji platform, and (6) all the other areas not considered in the previous zones. The geometry of the Tonga and New Hebrides subduction-interface models is based on the Slab 1.0 model of Hayes and others (2011) which applies bathymetry, seismicity, and reflection-profile data to constrain the 3D non-planar geometry of subduction zones from the trenches through the base of the seismogenic layer. We define the interface zones as the seismicity contained within the region above the $10 \mathrm{~km}$ to $50 \mathrm{~km}$ depth contours indicated by the Slab 1.0 model. It is clear that some of the seismicity included above this depth interval is not located on the interface but may have ruptured within the slab. It would be helpful in the future to define a 3D zone or analyze the focal mechanisms to better differentiate the interface and intraslab earthquakes. The outer-rise zone parameters were based on the location of 
abundant normal fault earthquakes on the leading edge of the subducting slab, in the region where the slab bends due to frictional resistance as the tectonic plate descends. The ends of the outer-rise zones are defined at the end of the mapped subduction zones of Pelletier and others (1998) and Bird (2003) (fig. 1 of this report). The northern boundary of the Tonga zone was defined along a lineament of seismicity that extends southwest across the map. Seismicity is much sparser to the north of that zone. The Fiji zone outlines the Fiji platform which can be observed in the bathymetry data and is defined by many of the geologic structures shown by Pelletier and others (1998) and Bird (2003).

\section{Ground Motion Model}

In this section we describe newly processed strong-motion data for large earthquakes across the Pacific basin and GMPEs that are used in assessing the ground motions across Southeast Asia. The strong-motion data are used to compare the different GMPEs and determine a weighting scheme for the hazard analysis. The GMPEs examined in this analysis were the Youngs and others (1997) (also known as the Geomatrix Consultants, 1997), the Atkinson and Boore (2003), and the Zhao and others (2006) for subduction zone and deep earthquakes, and the Boore and Atkinson (2008), Campbell and Bozorgnia (2008), and Chiou and Youngs (2008), and Zhao and others (2006) for shallow crustal equations. These equations were used in developing the U.S. National Seismic Hazard Maps (Petersen and others, 2008).

\section{Summary of Current Ground Motion Prediction Equations}

Youngs and others (1997) used a global subduction data set containing 350 horizontalcomponent response spectra compiled for earthquakes through 1989; this data set was compiled by adding data to a version of the subduction database compiled by Crouse (1991). Youngs and others (1997) developed their attenuation relationship for subduction zone interface and intraslab earthquakes of moment magnitude M 5 and greater and for distances of 10 to $500 \mathrm{~km}$. In addition, they simulated ground motions from large interface earthquakes to determine the appropriateness of their model for moment magnitude and distance between the site and the rupture $\left(\mathrm{R}_{\text {rup }}\right)$ that were not well represented in their data set. Specifically, they simulated earthquakes with $\mathrm{Mw}$ greater than 8 for interface earthquakes and $R_{\text {rup }}$ less than $30 \mathrm{~km}$, as well as distances greater than $300 \mathrm{~km}$, for both interface and intraslab earthquakes and provide regression coefficients for rock and soil site classes. They assume that average velocity properties of the rock ground motions included in their analysis is similar to a National Earthquake Hazards Reduction Program (NEHRP) soil catalogory A (characterized by shear wave velocity in the upper 30 meters $(\mathrm{m})$ that is greater than $5000 \mathrm{feet} / \mathrm{second}(\mathrm{ft} / \mathrm{sec})$ or 1500 meters per second $(\mathrm{m} / \mathrm{sec}$ ) but that it is close to a NEHRP B category (characterized by shear wave velocity in the upper $30 \mathrm{~m}$ between $2,500 \mathrm{ft} / \mathrm{sec}$ or $760 \mathrm{~m} / \mathrm{sec}$ and $5,000 \mathrm{ft} / \mathrm{sec}$.

Atkinson and Boore (2003) used a global subduction data set containing 1,200 horizontalcomponent spectra compiled for earthquakes through 2001. This data set was developed by combining the original subduction database from Crouse (1991), the updated subduction database from Youngs and others (1997), and additional events from Cascade, Japan, Mexico, and Central America. They also updated metadata in the database that may have been incorrect or missing. To check the validity of combining regional data sets into a global data set, Atkinson and Boore (2003) investigated whether there were systematic differences in ground motions from different regions. They found that the Cascade region of the northwest United States and southwest Canada and the area surrounding Japan showed regional variations. However, the average residuals for other regions were not significantly different from zero. Atkinson and Boore (2003) suggested that the regional differences seen in Japan 
and the Cascade region were attributable to regional differences in the depth of the typical soil profiles of the two regions. Consequently, Atkinson and Boore (2003) developed a global attenuation relationship and provided regional correction factors for the Cascade and Japan regions. Atkinson and Boore (2003) concluded that there were limitations on the applicability of global relations to any specific region and that the applicability of global relations to any region could be improved by using average residuals as regional-correction factors. The global attenuation relationship and the regional correction factors were optimized for the magnitude and distance range of engineering interest by limiting the final regression to data that fell into specific magnitude-distance range bins. The performance of the equations at larger distances than those used in the regression was checked by examining plots of the residuals and was found, with a few exceptions, to have a mean near zero in the important distance range within $100 \mathrm{~km}$ of the fault. The regression equations of Atkinson and Boore (2003) are given for site classes of rock (NEHRP B) or soil (NEHRP C, D, and E).

Zhao and others (2006) used a global data set containing 4,726 horizontal-component spectra. Records from the Japan region made up the majority at 4,518 records. In this data set, 1,285 records were from crustal events, 1,508 were from interface events, and 1,725 were from intraslab events. Twelve records from regions outside Japan were added to their database of Japanese interplate events to fill in for missing magnitude-distance ranges, while no records from regions outside of Japan were added to the intraslab database. Unlike Youngs and others (1997) and Atkinson and Boore (2003), Zhao and others (2006) did not publish or distribute their final database to the user and research community (citing data ownership-privacy issues) and thus, the following inferences were made by examining the figures provided in their paper (Zhao and others, 2006). Figure 1 of Zhao and others (2006) shows magnitude, focal depth, and source-distribution plots of their data set. These plots show the distance distribution for the interface events ranging between 30 and $300 \mathrm{~km}$ with most recordings occurring at distances greater than $50 \mathrm{~km}$, and for intraslab events between 40 and $300 \mathrm{~km}$ with most occurring at distances greater than $60 \mathrm{~km}$. The magnitude distribution varies between Mw 5 and 8, with most earthquakes having magnitudes less than 6.0. The focal-depth distribution for the interface events ranges fairly evenly between 15 and $50 \mathrm{~km}$. The intraslab events have distances that are distributed less evenly between 20 and $125 \mathrm{~km}$, with most events occurring between 45 and $80 \mathrm{~km}$. Zhao and others (2006) consider four site classes: SC I, II, III, and IV, which they claim are similar to rock, hard soil, medium soil, and soft soil, respectively. They consider the average shear wave velocity of the SC I category (rock) to be about $700 \mathrm{~m} / \mathrm{sec}$. Zhao and others (2006) state that the intraslab equations should not be used for depths less than about $40 \mathrm{~km}$, since there is little data to constrain these equations in this distance range. We considered using the Zhao and others (2006) intraslab equations for shallow crustal earthquakes, but felt that this would not be recommended by the authors of the ground-motion model. Instead we apply the Zhao and others (2006) crustal and next generation attenuation relations described below.

The Next Generation Attenuation (NGA) project developed ground-motion models for shallow crustal earthquakes in active crustal margins. This research effort involved (1) developing a consistent database of 3,551 recorded ground motions from 173 earthquakes as well as background information on processing and parameters that define the earthquake source, path, and site conditions of the strong motion record; and (2) developing five independent ground-motion models by developer teams that interacted through workshops and working meetings (Power and others, 2008). The USGS National Seismic Hazard Maps applied three equations of Boore and Atkinson (2008), Campbell and Bozorgnia (2008), and Chiou and Youngs (2008) based on working group discussions (Petersen and others, 2008). These ground-motion-prediction equations were developed for peak ground acceleration, peak ground velocity., and 5-percent damped spectral accelerations in the period range of 0 to $10 \mathrm{sec}$; the equations 
included models for strike-slip, reverse, and normal earthquake mechanisms; they considered ground motions for magnitude 5 to 8.5 earthquakes; they developed models for distance ranges of 0 to $200 \mathrm{~km}$; and they used shear wave velocity in the upper $30 \mathrm{~m}$ (Vs30) site classifications.

Figures 10 through 13 show primary features of the subduction zone and intraslab (deep) GMPEs and illustrate how ground motions decay as a function of distance, magnitude, mechanism of earthquake, and depth. These figures show the spectral accelerations for 1 hertz $(\mathrm{Hz})$ and $5 \mathrm{~Hz}$ for interface and intraplate earthquakes. Results indicate that amplitudes from intraplate (intraslab) events are larger near the source but decay faster with distance than ground motions from interplate events for similar sizes and distances. Intraslab earthquake ground motions for M 7.5 are greater than the ground motions from similar size events occurring on the plate interface at distances less than $100 \mathrm{~km}$, for both $1 \mathrm{~Hz}$ and $5 \mathrm{~Hz}$ spectral-acceleration models.

Each ground-motion model for intraslab earthquakes has terms that allow for increased ground motion with depth; however, estimates of the ground shaking are not well constrained for depths below $200 \mathrm{~km}$, and this data was not typically considered in developing the prediction equations. Atkinson and Boore (2003) and Zhao and others (2006) recommend that the ground motions should not continue to increase for earthquakes with depths greater than $100 \mathrm{~km}$ or $125 \mathrm{~km}$, respectively. Therefore, we limited the intraslab ground motions obtained from the Atkinson and Boore (2003) equations from continually increasing for depths below $100 \mathrm{~km}$. Similarly, we have limited the intraslab ground motions obtained from the other two equations from growing at depths below $125 \mathrm{~km}$. Figure 13 shows how these ground motions vary with the earthquake depth. For an M 7.5 earthquake, the ground motions are typically lower for deep earthquakes out to about $50 \mathrm{~km}$ (epicentral distance) than for shallower earthquakes. However, at larger epicentral distances, the curves cross over, and deep earthquakes can generate similar or larger ground motions than shallower earthquakes. Future studies should focus on ground motions from earthquakes with depths deeper than $200 \mathrm{~km}$ since these data not well constrained.

Figures 14 and 15 show comparisons between the shallow crustal sources and comparisons of the crustal, intraslab, and subduction-interface ground-motion models. Figure 14 shows comparisons of the Zhao and others (2006) and one of the Next Generation Attenuation ( NGA) equations developed by Boore and Atkinson (2008). In general the Boore and others model is lower than the Zhao models for M 7 to 8 but is a little higher for M 6 earthquakes at 1 and 0.2 second spectral acceleration ground motions. Figure 15 shows that crustal earthquakes are similar to interface earthquake ground motions out to 200 $\mathrm{km}$ distances while the intraslab models predict higher ground motions at shorter distances.

For this analysis we present seismic hazard maps for shear wave velocity in the upper $30 \mathrm{~m}$ (Vs30) of 760 meters per second (m/s), which is the soil condition applied in the building codes. We use the rock equations for each of the GMPE's. We recommend that future efforts are put into collecting Vs30 data at seismic recording stations and that ground motion models are developed that include a Vs30 term. This would bring down the uncertainty associated with these ground motions.

\section{Strong-Motion Data}

Spectral ground motions were measured from over ten years (1995-2007) of strong and weak motions of earthquakes located less than $1,000 \mathrm{~km}$ from nine permanent United States Geological Survey (USGS) Global Seismographic Network (GSN) stations near Pacific Rim subduction zones (table 2). The strong motion instrumentation of the GSN consists of a Quanterra Q330HR digitizer and three-component piSensor Accelerometer and real-time communications. Ground-motion sensors and communication-system electronics are housed underground in large waterproof vaults in order to achieve good coupling and to protect equipment from damage due to excessive moisture (detailed station information can be found online: http://earthquake.usgs.gov/monitoring/operations/.) For 
example, the vault at the Samoa station(with the code IU.AFI, fig.16 and .able 2) is a small concrete block building set into the ground with the roof at ground level and the concrete floor on solid Pleistocene Salani Volcanics basalt bedrock. Seismometers sit on piers that are not isolated from the vault floor. Station site resonance was estimated with Nakamura's method that calculates the horizontal component to vertical component ratio (H/V) method using 248 earthquakes recorded at the Samoa GSN station (McNamara and others, 2009). The mean H/V estimate at IU.AFI displays no significant resonance. We do not have direct measurement of Vs30 at any of our stations. Broadband seismometers of the GSN record 40 samples per second, and strong motion instruments record 100 samples per second.

Figure 16 shows the earthquakes and GSN strong-motion stations that recorded M 6.0 to M 8.1 earthquakes at distances between 47 and $973 \mathrm{~km}$. Figure 17 shows graphs of the strong-motion data recorded at these stations, along with the Zhao and others (2006) rock intraslab equation for $1 \mathrm{~Hz}$ spectral acceleration and peak horizontal ground acceleration. While the data are similar to the prediction equations for peak horizontal ground acceleration (PGA), the data recorded at 1-Hertz are typically a little higher than the Zhao and others (2006) equation. However, it is important to point out that the data have very large scatter about the GMPE. We examined the residuals of the data as a function of magnitude and distance to determine the weighting of the GMPEs. This is described in the next section.

Figure 18 shows the magnitude, distance, and depth distribution of GSN data that we considered. We analyzed 73 moment tensors to assess intraslab and interface earthquakes; our analysis indicated that 62 of the records were from intraslab and 11 were from interface earthquakes. More than half of the interface earthquakes were from earthquakes in Alaska. Magnitudes are plotted as a function of distance and depth for interface and intraslab events.

During November, 2009, the USGS deployed five portable strong-motion seismometers (Reftek Mems seismometers, Reftek RT-130 digitizers) with the goal of recording aftershocks of the 29 September, 2009, M 8.0 Samoan earthquake. Continuous seismic data and corresponding metadata for all stations were retrieved from the online archives of the USGS Albuquerque Seismological Laboratory (ASL) Data Collection Center (DCC). All waveform data from both portable and permanent seismic stations used in this study are archived and available for download from the Incorporated Research Institutions for Seismology (IRIS) Data Management Center (DMC; http://www.iris.edu/data/). In our preliminary analysis of these shaking data, we could not distinguish between interface and outer rise ground motions (McNamara and others, 2009).

In analyzing the GSN records, the time-series window was chosen to include all energy from crustal P-waves $(\mathrm{Pg})$ to later-arriving upper mantle S-waves $(\mathrm{Sn})$ and surface waves (window bounded by seismic velocity of 9 kilometers per second $(\mathrm{km} / \mathrm{s})$ to $2 \mathrm{~km} / \mathrm{s}$ from the earthquake origin time). Origin times and magnitudes used in this study were obtained from USGS Preliminary Determination of Epicenters (PDE. Additional data processing to obtain absolute ground acceleration included deconvolution of the instrument response transfer function from the demeaned and tapered time series. Finally, the response spectral estimates were measured using the 100 samples per second threecomponent acceleration time series in the frequency band, 0.33 to $20 \mathrm{~Hz}$. All waveforms were visually inspected for quality and accuracy. We calculated the geometric mean of the horizontal components for each earthquake station for use in this analysis. We calculated spectral acceleration as described in McGuire (2004). 


\section{Analysis of Ground Motion Prediction Equations}

We evaluated three ground GMPEs (Youngs and others, 1997; Atkinson and Boore, 2003; and Zhao and others, 2006) to determine how well they fit the ground-motion data we collected in the Pacific Arc Island region. We also compare the equations to some large earthquakes that occurred near Japan (appendix 1). The purpose of this evaluation was to assist in GMPE selection and weighting for this hazard analysis. Two performance measures were considered. The first evaluation assessed how well each GMPE modeled the magnitude and distance dependence of the ground-motion amplitudes. The second examined if the GMPE systematically over- or under-predicted the ground-motion amplitude. Table 2 shows the earthquake parameters and recording station information. Tables 3-5 show the observed ground motions and the ground motions predicted spectral accelerations of 1 Hertz (Hz) (1-second (sec) period) and $5 \mathrm{~Hz}(0.2$-sec period) and peak horizontal ground accelerations

For this analysis, we restricted the data to events with rupture distances less than $300 \mathrm{~km}$; this was the approximate cutoff distance of the three GMPEs considered. This reduced the data set to 73 horizontal-component response spectra for the geometric mean recorded by eight stations (table 2). Six stations (ADK, AFI, GUMO, RAO, HNR and TATO) had six or more recordings; two stations (DAV and PET) had only one record. Of the eight stations, AFI recorded the greatest number of events: 17 (fig. 16). In general, our results do not indicate any particular region of the circum-Pacific varying systematically. However, strong motion data recorded at station RAO (near the Kermadec trench) were considerably higher than the predicted values. Additional examination of strong motion records from RAO did not lead us to exclude these recordings. However, written descriptions of station RAO indicate that it is located near the edge of a small island with a 200 -foot cliff. Therefore, it is possible that these records include topographic amplifications.

Because of the sparse station distribution, no earthquake is recorded at more than one station. Some stations recorded more earthquakes than others, which could lead to a bias in the statistical analysis. Therefore, we take the station characteristics (including site response) and the number of recordings at each station into account in analyzing the residuals. We do not have direct shear wave velocity in the upper $30 \mathrm{~m}$ (Vs30) measurements at any of the stations; however, most of the stations are located on volcanic islands, so it is probable that many of these sites are located on rock or rock which is overlain by a thin layer of alluvium. In this analysis, we remove these average site effects based on the comparison with the GMPEs for rock, which we assume is close to $760 \mathrm{~m} / \mathrm{s} \mathrm{Vs} 30$. The station effects are removed as described below and in Appendix 2. This analysis would be much more robust if we had direct Vs30 measurements at each station.

We use a random-effects regression model that solves for regression-model parameters and the systematic offset of the station terms (site effects) using a maximum likelihood approach (Appendix 2). We applied the regression model of Abrahamson and Youngs (1992), which is equivalent to a twostaged regression analysis (Brillinger and Preisler, 1985; Joyner and Boore, 1993). This approach assumes that if there are two or more observations at a single station, then these observations are correlated through site effects. If there are many recordings at a single station, then the random-effects model computes a station term that is approximately equal to the average total residual at each station and represents the overall site effect. If there is only one or a few observations, then the random-effects model computes a station term that is based on a combination of the station term variance and a global random variance based on the entire data set.

The random-effects regression was performed on the residuals obtained by subtracting the GMPE predicted ground motion (as a function of magnitude, distance, site, etc.) from the observed ground motion. The residuals were fit to the following linear model that is similar to the Lin and others (2011) approach: 


$$
\operatorname{Resid}=y-\bar{y}=C_{1}+\eta_{i}+\zeta_{i j}
$$

Where:

$y$ is the data,

$\bar{y}$ is the GMPE,

$C_{1}$ is a constant term that accounts for the differences in the model and the regional data set and could

be considered as a regional source term,

$\eta_{i}$ is the inter-event term and in our case acts as the station term because we use a sparse data set comprised of earthquakes that are recorded only at a single station,

$\zeta_{i j}$ is the intra-event term that represents the remaining residual or 'left-over' term after the residuals have been fit to Equation 1,

$i$ is the station index, and

$j$ is the source index.

The constant term is a systematic offset of the data and essentially accounts for regional differences that exist between the ground motion of the data set and the predicted GMPEs. This term was added to the random-effects model to accommodate any overall systematic differences between the empirical data and the model estimate. We use this term in our analysis to account for a regional shift in the median ground motion for our logic tree uncertainty analysis. The station term accounts for the station-to-station differences, most likely explained by the site effects at the station. The "left-over term," herein described as "single-station residuals," accounts for all other un-captured effects that contribute to the ground motion variability, such as path effects and aleatory variability.

In analyzing ground motion residuals for GMPE performance, the analysis should be done using the uncorrelated residuals and not the correlated residuals. In this study, this requirement for uncorrelated residuals implies that we should remove the contribution to the ground motion from site effects and constant offset before analyzing the residuals for unevenly sampled data. If correlated residuals were used, results from this analysis would be biased towards the individual source, path, and site effects of the events, paths and stations that were sampled the most.

Figures 19-21 show examples of how we remove the station correlations from the total residuals for PGA, $5 \mathrm{~Hz}$, and $1 \mathrm{~Hz}$, respectively. For example, Figure 19A shows the average total residual at each station. Figure $19 B$ shows the station term. Figure $19 C$ shows the average single-station residual at each station which has the station term and constant offset removed (uncorrelated). This effectively removes the site effect based on the average station bias. Figures 20 and 21 show the same details but for $5 \mathrm{~Hz}$ and $1 \mathrm{~Hz}$, respectively. This concept is more fully explained in appendix 2.

To understand the residual trends, we plotted the single-station residuals as a function of magnitude; single-station residuals are the residuals with the systematic offset and station terms removed. This is demonstrated by comparing figure $22 A$ and $B$. Figure $22 A$ shows the total uncorrected PGA residuals for moment magnitude. Figure $22 B$ displays the uncorrelated single-station residual terms; correlations from station effects and systematic offset of the data have been removed. The dispersion of the residuals is noticeably larger in figure $22 \mathrm{~A}$ than in figure $22 \mathrm{~B}$. The single-station residuals versus moment magnitude are seen in figure $22 B, C$, and $D$ for PGA, $5 \mathrm{~Hz}$, and $1 \mathrm{~Hz}$ respectively, in which the blue squares, green triangles and red dots represent the Atkinson and Boore (2003), Zhao and others (2006) and the Youngs and others (1997) model residuals, respectively. The positive residual trend (negative slope of the blue squares) seen in figure $22 \mathrm{~A}$ from the Atkinson and Boore (2003) model illustrates that their global model under-predicts ground motions at the smaller magnitudes and over-predicts at the larger magnitudes. The Zhao and others (2006) residuals appear to 
be centered close to zero for M less than 7.4. All of the models over-predict ground motions for large magnitudes.

It is interesting to note that the GMPEs shown in figure 22 over-predict the ground motions for earthquakes near M 7.9. There are four earthquakes with $\mathrm{M}$ of about 7.9; these earthquakes are recorded at stations between 40 and $300 \mathrm{~km}$ in the Aleutians (1996, 2003), Samoa (2009), and Solomon Islands (2007). The earthquakes are shallow and include both interface and outer rise earthquakes. We do not have a good explanation for this bias at large earthquakes. However, it could be related to the small number of large earthquake data available for developing the models. To analyze these residuals, we first examined the rate of amplitude decay (as a function of both magnitude and distance) for PGA and spectral frequencies $5 \mathrm{~Hz}$ and $1 \mathrm{~Hz}$.

We model trends by calculating the average single station residual and the standard deviation within different magnitude bins; these average residuals are plotted in figures $23 \mathrm{a}, \mathrm{b}$, and c for PGA, 5 $\mathrm{Hz}$, and $1 \mathrm{~Hz}$, respectively. For $\mathrm{M}_{\mathrm{w}}$ less than 7.4, the average residual was estimated with 10 or more points. For $\mathrm{M}_{\mathrm{w}}$ greater than 7.4, the average residuals were estimated using only two values and are not as well constrained. Figure 23 graphs show that the average residuals for all three GMPEs tend to center near zero for $\mathrm{M}$ less than 7.4, where the data is most abundant. The average residuals for larger earthquakes are significantly larger than for smaller earthquakes for all of the equations. We calculated the standard deviation for PGA data in these magnitude bins and found that the Zhao and others (2006) equation generally had lower sigmas compared to the other GMPEs, but this was not always the case.

In a similar manner, the overall rates of amplitude decay with rupture distance were explored by computing the average single-station residual for various distance bins. Figure $24 A$ shows all the singlestation residuals as a function of distance for PGA. Figures $24 B, C$, and $D$ show the average singlestation residuals binned by distance for PGA, $5 \mathrm{~Hz}$, and $1 \mathrm{~Hz}$, respectively. For rupture distances between 200 and $300 \mathrm{~km}$, the average residual was estimated using 10 points or more and is fairly well constrained. For distances ranging between $40 \mathrm{~km}$ and $200 \mathrm{~km}$, the number of points in each distance bin averaged between 1 and 5, and is not as well constrained. From inspection of figures $24 \mathrm{~b}$, c, and d, all of the equations over-predict ground motions at larger distances and under-predict for short distances less than $100 \mathrm{~km}$. The Geomatrix intraslab equation over-predicts more than the other GMPEs at distances beyond $300 \mathrm{~km}$ (fig. 11). The Zhao and others (2006) equations appear to us to be more compatible with the data over the entire range of distances than the other two equations.

Next, we investigated if a systematic difference existed between the ground motions of the data set and the global or regional GMPEs. Table 6 shows systematic offset for the data and the ground motion prediction equations. Several ground-motion experts have investigated the validity of using GMPEs to adequately represent any one region. Atkinson and Boore (2003) found systematic regional differences between the ground motions recorded in the Cascade and Japanese regions and found no conclusive regional differences in the Mexico, Peru, and Alaska regions. They explained that the regional differences they saw were attributable to the depth of the typical soil profiles of the Cascade and Japan regions and recommended correction factors to their model for these two regions. Abrahamson and others (2011) found that on average, the ground motions from different regions showed no systematic differences, except in the Cascade region. In a similar vein, we checked for average regional differences between the Samoa strong motion data set and each GMPE. If they exist, we checked if regional correction factors would be appropriate for estimating the ground motion of the Samoa Hazard. The regional differences were again investigated by performing the regression using the random effects model, including a constant term (regional offset term) that we added to the regression. Table 6 lists this data set constant term for the Zhao and others (2006) model at PGA and spectral frequencies, $5 \mathrm{~Hz}$ and $1 \mathrm{~Hz}$. The ground motions computed using the Geomatrix Consultants (1997) 
model had the largest offset from the Samoa data set, while the Zhao and others (2006) has the smallest. As in the Atkinson and Boore (2003) model, these terms may be used as regional correction factors to improve the GMPEs' estimates of the ground motions in the Pacific region.

The last measure we used to assess performance of each GMPE was to analyze the standard deviation of the residuals at PGA, 5Hz and $1 \mathrm{~Hz}$ for each model. Standard deviations for each model are recorded in table 7. The Geomatrix Consultants (1997) and Atkinson and Boore (2003) model have the largest standard deviations that range between 0.65 and 1.0. Many of these sigmas are larger than typical GMPEs for pga and $1 \mathrm{~Hz}$ and $5 \mathrm{~Hz}$ Spectral accelerations. The Zhao and others (2006) standard deviation at $1 \mathrm{~Hz}$ of 0.717 is within the range of typical GMPE sigma values.

Our analyses indicate that the Zhao and others (2006) GMPE captures the ground motion amplitude dependence on magnitude and distance better than the other models for this Pacific island region. In addition, the Zhao and others (2006) model appears to better fit the strong motion data from subduction data off the Japan coast (Appendix 1). Youngs and others (1997) shows a much smaller rate of decay in ground-motion amplitude with distance and Atkinson and Boore (2003) shows a much larger rate of decay in ground motion amplitude with moment magnitude than observed. In addition, each GMPE systematically over- or under-predicts the ground motion amplitudes at PGA and spectral frequencies at $5 \mathrm{~Hz}$ and $1 \mathrm{~Hz}$. The systematic shift is lowest for the Zhao and others (2006) equation and this offset is shown in table 6. This suggests that the ground motions within the Pacific Arc Island region may be different than other regions; however, a larger and more complete database is needed to confirm this. The epistemic uncertainty concerning whether regional differences exist or not is incorporated in the seismic hazard analysis as a branch option of the logic tree. However, because of the sparse nature of the data set we compiled, we have given this option lower weight. The average overprediction by the GMPEs can be used as regional correction factors that may better predict the ground motions of the Samoa region. Tables 7-9 show the single station sigma, station sigma, and total sigma for each of the three evaluated ground motion prediction equations. Using these data we decided to use only the Zhao and others (2006) equations for interface and intraslab earthquakes. We applied the correction factors shown in Table 6 for the Zhao and others (2006) equations to account for epistemic uncertainty in this analysis. We only use the Zhao and others model to capture the magnitude and distance dependence of the ground motions because it fits this limited data set best. The rock model of Zhao and others (2006) is probably more similar to the Vs30 of $760 \mathrm{~m} / \mathrm{s}$ that is required in the NEHRP building codes.

The Zhao and others (2006) model is run using the rock site condition for both interface and intraslab earthquakes. Zhao and others (2006) indicate that their rock equation is consistent with a Vs30 of about $700 \mathrm{~m} / \mathrm{s}$ which is similar to the Vs30 of $760 \mathrm{~m} / \mathrm{s}$ required by the building codes in the United States. We only apply the interface models for earthquakes near or on the interface, and we apply the intraslab model for all other earthquakes in the model (table 1). In developing the hazard model we decided to use the continental crustal earthquake equations (for example, Next Generation Attenuation Relation (NGA); see Petersen and others 2008 for further details) and the Zhao and others (2006) shallow crustal ground motion model.

\section{Logic Tree for Seismic Hazard}

The final logic tree that we used for this hazard analysis is shown in figure 25. Branches of the logic tree are shown for magnitude uncertainty and ground motion models. As discussed in the sourcemodel section, we considered earthquakes with a maximum magnitude of 8.5 or 9.0. This decision does not make a large impact on the ground motions, with the M 9.0 model being higher by about 5 percent to 10 percent. The implied slip rate from our model with maximum magnitude of 8.5 is about 4.5 
centimeters per year (cm/yr) for the New Hebrides and about $2.5 \mathrm{~cm} / \mathrm{yr}$ for the Tonga Subduction Zone. The rate for the model with maximum magnitude of 9.0 is about $9.5 \mathrm{~cm} / \mathrm{yr}$ for the New Hebrides Subduction Zone and about $5 \mathrm{~cm} / \mathrm{yr}$ for the Tonga Subduction Zone. These implied slip rates account for less than half of the total slip rates shown in figure 1 . Therefore, it is probable that a significant portion of the overall slip rate is occurring aseismically. For the ground-motion models, we assigned weights as described above based on the residual analysis. Alternative weights were assigned for ground-motion models from earthquakes with depths down to $200 \mathrm{~km}$ and for earthquakes located at greater depths based on the residual analysis. We found that ground motions for earthquakes between 10 $\mathrm{km}$ and $200 \mathrm{~km}$ depth had similar characteristics.

For this hazard assessment, we apply zero weights to the Atkinson and Boore (2003) and Geomatrix Consultants (1997) equations. However, we use the variability in the mean of all of these published equations to estimate epistemic uncertainty. This epistemic variability between the three published GMPEs in the distance range that contains most of the strong motion data (between $100 \mathrm{~km}$ and $500 \mathrm{~km}$ ) is about 25 to 50 percent (figs. 10 and 11). The uncertainty is larger for large magnitude (M 9) earthquakes at distances greater than $200 \mathrm{~km}$. We assumed a constant 25 percent epistemic uncertainty for the Zhao equation to account for modeling the ground motions. This epistemic uncertainty could be modeled as a function of magnitude and distance in the future.

Most of the weight (70 percent) is applied to the Zhao and others (2006) intraslab equation based on our analyses described earlier that shows a good correspondence between the data and GMPE. However, we also defined a regional model by using the constant term (shift or offset) that we calculated from the random effects model to account for a small bias. This shift is defined in Table 6 and is a function of the ground motion parameter (that is, PGA, $5 \mathrm{~Hz}$, or $1 \mathrm{~Hz}$ ), but is most significant for $1 \mathrm{~Hz}$. We considered that this regional model did not utilize as much data as applied in the Zhao and others (2006) equations. Therefore, we assigned smaller weight (30 percent) for the possibility that there are regional differences. This regional model is only applied to the intraslab equations. We apply 100 percent of the weight to the Zhao and others (2006) interface equation because our regional data set only contained 11 geometric mean records (9 after distance was limited to $200 \mathrm{~km}$ ) for interface earthquakes and most of these records were from Alaska and not the Samoa region. The Zhao and others (2006) intraslab and interface equations capture the magnitude and distance dependence and seem to have a functional form that is more consistent with our data set.

For shallow crustal earthquakes, we apply the Zhao and others (2006) crustal equation with a depth of $10 \mathrm{~km}$ with half weight and the average of the three NGA equations of Boore and Atkinson (2008), Campbell and Bozorgnia (2008), and Chiou and Youngs (2008) with a depth of $10 \mathrm{~km}$ with appropriate faulting types (normal, strike-slip, and reverse mechanisms).

\section{Results}

The relative contributions of each source to the overall ground-motion hazard is displayed in figures 26 to 28 for $1 \mathrm{sec}(1 \mathrm{~Hz})$ and $0.2 \mathrm{sec}(5 \mathrm{~Hz})$ spectral accelerations. Ground motions caused by earthquakes on the Wadati-Benioff zone dominate the hazard (fig. 26) and fall off with distance from the plate interface. Figure 26 also shows the global moment tensors and ground motions for a 2 percent probability of exceedance in $50 \mathrm{yr}$ on a uniform firm rock site condition. Ground motions can exceed 1 $\mathrm{g}$ for $1 \mathrm{~Hz}$ spectral acceleration over the two subduction zones. Figures 27 and 28 shows the hazard contributions from earthquakes at different depth intervals. Ground-motion hazard is highest for the seismicity less than $100 \mathrm{~km}$ and ground motions decrease with increasing depth beyond $100 \mathrm{~km}$. It is important to point out that the ground motions associated with deep earthquakes have not been studied well. Future work and data may help us better constrain and understand this shaking from deep 
earthquakes that has caused light damage over broad areas (for example, 1994 M 8.2 Bolivia earthquake, this earthquake was $642 \mathrm{~km}$ deep and caused limited damage).

Spectral accelerations at $1 \mathrm{~Hz}$ and $5 \mathrm{~Hz}$ and peak horizontal ground-motion hazard maps (with 5percent damping) for this South Pacific region at 10 percent and 2 percent probabilities of exceedance in $50 \mathrm{yr}$ on a uniform firm rock site condition are shown in figures 29 through 34 . For assessment of sitespecific hazard, it is critical that further studies should consider local faulting (we did not include any crustal faults in this analysis) and ground-motion amplification (we only consider a firm rock site condition). These hazard maps were only produced for a single Vs30 $=760 \mathrm{~m} / \mathrm{s}$ site condition, so these hazard values need to be modified for appropriate site effects. The map shows some bubbles of hazard near American Samoa that are caused by M 5 earthquakes. We examined the data and note that one of these earthquakes had M 5.2 and a normal mechanism.

The GSHAP model for this region shows 10 percent probability of exceedance in 50 yr groundshaking hazard for unspecified site conditions. This model was developed by cobbling together past regional hazard assessments and site-specific studies for dams and mines (McCue, 1999). McCue (1999) indicates that reasonable design coefficients are $0.2 \mathrm{~g}$ for Western Samoa and $0.15 \mathrm{~g}$ for American Samoa, but it is unclear which site condition or return periods McCue considers. McCue indicates that Fiji has experienced damaging earthquakes and that the hazard is comparable to many parts of Australia, which the GSHAP map indicates has low to moderate hazard-less than about $0.16 \mathrm{~g}$. They also suggest that peak horizontal ground motions across the region are high (4.0 meters per second squared $\left(\mathrm{m} / \mathrm{s}^{2}\right)$, or about $\left.0.4 \mathrm{~g}\right)$ near the subduction zones and moderate $\left(0.8\right.$ to $1.6 \mathrm{~m} / \mathrm{s}^{2}$ or about $\left.0.1 \mathrm{~g}\right)$ near New Caledonia for this 475-yr return period. Our 10 percent probability of exceedance in the $50 \mathrm{yr}$ model is consistent with the lower peak ground acceleration hazard values showing about $0.13 \mathrm{~g}$ near Samoa and $0.1 \mathrm{~g}$ in southern New Caledonia for a similar return period on a firm rock site condition $(\mathrm{Vs} 30=760 \mathrm{~m} / \mathrm{s})$. However, our hazard maps for 10 percent probability of exceedance in $50 \mathrm{yr}$ on firm rock site condition for Fiji indicate about $0.15 \mathrm{~g}$ peak ground acceleration, which is a little higher than the GSHAP maps indicate for hazard across Australia. Along the subduction zones, our peak ground acceleration hazard values are higher than the GSHAP model, which shows ground motions considerably greater than $0.4 \mathrm{~g}$. These differences could relate to our use of different ground-motion models or that we have misinterpreted the site conditions of the GSHAP model. For example, in early versions of this model, we used the Zhao and others (2006) intraslab to characterize shallow crustal earthquakes rather than the crustal models we selected in the final model. This ground-motion-model modification resulted in decreased ground motion from about 15 percent to 40 percent in the 2 percent probability of exceedance in $50 \mathrm{yr}$ ground motions compared with the final models. Other model choices could result in higher ground motions estimates since these models are so sensitive in the seismic hazard results.

The probabilistic seismic hazard model for Vanuatu developed by Suckale and Grünthal (2009) provides lower estimates of hazard than the model presented here. The Suckale and Grünthal (2009) model for peak ground acceleration on stiff soil at Port Vila, Vanuatu, is about $0.7 \mathrm{~g}$ for a 10-percent probability of exceedance in 50-yr level. If we assume that the stiff soil is consistent with a shear wave velocity in the upper $30 \mathrm{~m}$ (Vs30) of $360 \mathrm{~m} / \mathrm{s}$, then we would calculate a PGA hazard of $0.9 \mathrm{~g}$ which, is about 30 percent higher than the calculated hazard of Suckale and Grünthal (2009). Comparison of the $0.2 \mathrm{~s}$ - and 1-s spectral accelerations under these same assumptions of soil amplification also indicate that our values are significantly higher than the model developed by Suckale and Grünthal (2009). Again, the difference between our models could be related to the different suite of attenuation relations we apply, different b-values, different completeness times, or that we have misinterpreted their soil- 
classification scheme. We also use a higher maximum magnitude for the New Hebrides subduction zone than was applied in their hazard assessment.

Figures 35 to 38 show disaggregation plots that describe the primary contributors to the hazard along with the modal magnitude, distance, and epsilon (difference of the calculated ground motion from the median ground motion) that contributes most to the hazard. For the Pago Pago, American Samoa site, M 7.0 to 7.4 earthquakes at distances about $70 \mathrm{~km}$ on the Tonga outer rise are most important to the hazard at return periods from 10 to $10,000 \mathrm{yr}$ (fig. 35). However, large subduction interface earthquakes with magnitudes of about M 8.4 at large distances of $280 \mathrm{~km}$ are also significant, especially at $1 \mathrm{~s}$ spectral acceleration. For the site in Nuku'alofa, Tonga, the M 7.5 earthquakes at distances less than 110 $\mathrm{km}$ (located on the shallow Fiji platform) contribute most to the hazard, but the large subduction interface and Wadati-Benioff earthquakes are also significant, especially at $0.2 \mathrm{~s}$ spectral acceleration (fig. 36). At the Suva, Fiji site, the Fiji platform and Wadati-Benioff earthquakes with magnitudes about M 8.0 and distances close to $100 \mathrm{~km}$ dominate the seismic hazard for both $1 \mathrm{~s}$ and $0.2 \mathrm{~s}$ spectral accelerations (fig. 37). For the Port Vila, Vanuatu site, several sources contribute to the hazard, including the New Hebrides interface and shallow Fiji platform earthquakes (fig. 38). A broad range of magnitudes from M 6.3 to 8.7 are important contributors with modal distances for the earthquakes that contribute most to the hazard range from $30 \mathrm{~km}$ to $114 \mathrm{~km}$. For most of these sites, the high rates of earthquakes included in the source model lead to differences between the calculated and median ground motions (epsilon in deaggregation plots) that are greater than the median value. Large aleatory variability in the ground-motion models tends to increase the hazard across the region, since this is a very seismically active region and thus has epsilon values higher than the median.

These maps are being considered for inclusion in the International Building Code (2012 edition) for ground-motion design in American Samoa.

\section{Conclusion}

The hazard across American Samoa and the adjacent South Pacific islands varies significantly. Spectral acceleration hazard for $1 \mathrm{~Hz}$, having a 2-percent probability of exceedance on a firm rock site, condition $(\mathrm{Vs} 30=760 \mathrm{~m} / \mathrm{s})$ is $0.12 \mathrm{~g}(1 \mathrm{~Hz})$ and $0.32 \mathrm{~g}(5 \mathrm{~Hz})$ at a site on American Samoa, $0.72 \mathrm{~g}$ $(1 \mathrm{~Hz})$ and $2.5 \mathrm{~g}(5 \mathrm{~Hz})$ at a site on Tonga, $0.15 \mathrm{~g}(1 \mathrm{~Hz})$ and $0.55 \mathrm{~g}(5 \mathrm{~Hz})$ at a site on Fiji, and $0.89 \mathrm{~g}$ $(1 \mathrm{~Hz})$ and $2.8 \mathrm{~g}(5 \mathrm{~Hz})$ at a site on the Vanuatu Islands. If the site is located on something other than firm rock, it is important to amplify the hazard by a factor consistent with the soil or rock located at the site. The NEHRP has developed factors for this purpose (for example, Petersen and others, 2008). We recommend that more detailed, site-specific studies be completed for important structures.

\section{References Cited}

Abrahamson, N.A., and Youngs, R.R., 1992, A stable algorithm for regression analyses using the random effects model: Bulletin of the Seismological Society of America, v. 82, p. 505-510.

Atkinson G.M., and Boore, D.M., 2003, Empirical ground-motion relations for subduction-zone earthquakes and their application to Cascadia and other regions, Bulletin of the Seismological Society of America, v. 96, p 1703-1729.

Bird, P., 2003, An updated digital model of plate boundaries: Geochemistry Geophysics Geosystems, v 4, p. 1-52.

Boore, D.M., and Atkinson, G.M., 2008, Ground-motion prediction equations for the average horizontal component of PGA, PGV, and 5\% damped PSA at spectral periods between $0.01 \mathrm{~s}$ and 10s: Earthquake Spectra, v. 24, p. 99-138. 
Brillinger, D.R., and H.K. Preisler, 1985, Further analysis of the Joyner-Boore attenuation data: Bulletin of the Seismological Society of America, v. 75, p. 611-614.

Building Seismic Safety Council, 2009, NEHRP recommended seismic provisions for new buildings and other structures, FEMA P-750: Washington, D.C., Federal Emergency Management Agency (FEMA).

Campbell, K.W., and Bozorgnia, Y., 2008, NGA ground motion model for the geometric mean horizontal component of PGA, PGV, PGD and 5\% damped linear elastic response spectra for periods ranging from 0.01 to 10s: Earthquake Spectra, v. 24, p. 139-172.

Chiou, B.-J, and Youngs, R.R., 2008, An NGA model for the average horizontal component of peak ground motion and response spectra: Earthquake Spectra, v. 24, p 173-216.

Crouse, C., 1991, Ground-motion attenuation equations for Cascadia subduction zone earthquakes: Earthquake Spectra, v. 7, p 201-236.

The UK Earthquake Engineering Field Investigation Team, 2010, The South Pacific Islands earthquake and tsunami of $20^{\text {th }}$ September 2009: London, U.K., The Institute of Structural Engineers, 67 p., accessed at http://www.istructe.org/knowledge/EEFIT/Pages/reports.aspx,

Engdahl, E.R., and Villaseñor, A., 2002, Global seismicity-1900-1999, chap. 41 of Lee, W.H.K., Kanamori, H., Jennings, P.C., and Kisslinger, C., eds., International handbook of earthquake and engineering seismology, Part A: Amsterdam, Academic Press, p. 665-690.

Frankel, A.D., Petersen, M.D., Mueller, C.S., Haller, K.M., Wheeler, R.L., Leyendecker, E.V., Wesson, R.L., Harmsen, S.C., Cramer, C.H., Perkins, D.M., Rukstales, K.S., 2002, Documentation for the 2002 update of the National Seismic Hazard Maps: U.S. Geological Survey Open-File Report 02-420, 33 p. (Also available at http://pubs.usgs.gov/of/2002/ofr-02-420/.)

Frankel, A., 1995, Mapping seismic hazard in the Central and Eastern United States: Seismological Research Letters, v. 66, p. 8-21.

Gardner, J.K., and Knopoff, L., 1974, Is the sequence of earthquakes in southern California, with aftershocks removed, Poissonian?, Bulletin of the Seismological Society of America, v. 64, p. 13631367.

Geomatrix Consultants, 1995, Seismic design mapping state of Oregon: Oakland, Calif., Geomatrix Consultants, prepared for Oregon Dept. of Transportation, Transportation Building, Salem, Oreg., Section 3, $17 \mathrm{p}$.

Giardini, D., 1999, The global seismic hazard assessment program (GSHAP) -1992-1999: Annali di Geofisica, v. 42, p. 957-974.

Gutenberg, B., and Richter, C.F., 1944, Frequency of earthquakes in California: Bulletin of the Seismological Society of America, v. 34, p. 185-188.

Hayes, G.C., Wald, D.J., and Johnson, R. L., 2011, Introducing Slab1.0, a three-dimensional model of global subduction zone geometries, accessed June 21, 2012 at http://earthquake.usgs.gov/research/data/slab/.

Jaffe, B.E., Gelfenbaum, Guy, Buckley, M.L., Watt, Steve, Apotsos, Alex, Stevens, A.W., and Richmond, B.M., 2010, The limit of inundation of the September 29, 2009, tsunami on Tutuila, American Samoa: U.S. Geological Survey Open-File Report 2010-1018, 27 p., scale 1:222,200.

Joyner, W.B., and Boore, D.M., 1993, Methods for regression analysis of strong-motion data: Bulletin of the Seismological Society of America, v. 83, p. 469-487.

Lin, P., Chou, B., Abrahamson, N., Walling, M., Lee, C., Cheng, C., 2011, Repeatable source, site, and path effects on the standard deviation for empirical ground-motion prediction models: Bulletin of the Seismological Society of America, v. 101, p. 2281-2295. 
McCue, K., 1999, Seismic hazard mapping in Australia, the southwest Pacific and southeast Asia: Annali di Geofisica, v. 42, p. 1191-1198.

McGuire, R.K., 2004, Seismic hazard and risk analysis: Oakland, Calif., Earthquake Engineering Research Institute, EERI Monograph MNO-10, $221 \mathrm{p}$.

McNamara, D.E., Petersen, M.D., Meremonte, M.E., Fox, J., Leeds, A., 2009, Ground motions from the 29 September 2009 Samoa M 8.0 earthquake and aftershocks, in American Geophysical Union Fall Meeting, San Francisco, Calif., December 14-18, 2009, Proceedings: Washington, D.C., American Geophysical Union, accessed accessed June 21, 2012 at

http://adsabs.harvard.edu/abs/2009AGUFM.U21D..02M.

Okal, E.A., Borreo, J., and Synolakis, C.E., 2004, The earthquake and tsunami of 1865 November 17-Evidence for far-field tsunami hazard from Tonga: Geophysical Journal International, v. 157, p. 164-174.

Petersen, M.D, Frankel, A.D, Harmsen, S.C., Mueller, C.S., Haller, K.M., Wheeler, R.L., Wesson, R.L., Zeng, Y., Boyd, O.S., Perkins, D.M., Luco, N., Field, E.H., Wills, C.J., and Rukstales K.S., 2008, Documentation for the 2008 update of the United States National Seismic Hazard Maps: U.S. Geological Survey Open-File Report 2008-1128, 60 p, 11 appendixes. (Also available at http://pubs.usgs.gov/of/2008/1128/.)

Pelletier, B., Calmant, S., and Pillet, R., 1998, Current tectonics of the Tonga-New Hebrides region: Earth and Planetary Science Letters, v. 164, p. 263-276.

Power, M., Abrahamson, N., Bozorgnia, Y., Shantz, T., and Roblee, C., 2008, An overview of the NGA project: Earthquake Spectra, v. 24, p. 3-21.

Sipkin, S.A., 2003, A correction to body-wave magnitude mb based on moment magnitude Mw:

Seismological Research Letters, v. 74, p. 739-742.

Suckale, J., and G. Grünthal , 2009, Probabilistic seismic hazard assessment for Vanuatu: Bulletin of the Seismological Society of America, v. 99, p. 2108-2126.

Thronberry-Ehrlich, T., 2008, National Park of American Samoa-Geologic Resource Evaluation Report: Washington D.C., National Park Service, Natural Resource Report NPS/NRPC/GRD/NRR$2008 / 025$.

Utsu, T., 2002, Relationships between magnitude scales, in Lee, W.H.K., Kanamori, H., Jennings, P.C., and Kisslinger, C., eds., International handbook of earthquake and engineering seismology: Amsterdam, Academic Press, p. 733-746.

Wessel, P., and Smith, W.H.F., 2004, The Generic Mapping Tools (GMT) Version 4 Technical Reference and Cookbook: The Generic Mapping Tools, accessed June 21, 2012, at http://gmt.soest.hawaii.edu/.

Weichert, D.H., 1980, Estimation of the earthquake recurrence parameters for unequal observation periods for different magnitudes: Bulletin of the Seismological Society of America, v. 70, p. 1337-1356.

Youngs, R.R., Chiou, S.-J., Silva, W.J., and Humphrey, J.R., 1997, Strong ground motion attenuation relationships for subduction zone earthquakes: Seismological Research Letters, v. 68.

Zhao, J.X., Zhang, J., Asano, A., Ohno, Y., Oouchi, T., Takahashi, T., Ogawa, H., Iridura, K., Thio, H. K., Somerville, P.G., Fukushima, Y., and Fukushima, Y., 2006, Attenuation relations of strong ground motion in Japan using site classification based on predominant period: Bulletin of the Seismological Society of America, v. 96, p. 898-913. 


\section{Acknowledgments}

We thank Antonio Villisenor, Gavin Hayes, Emile Okale, George Choy, Art Frankel, and Kevin Furlong, for constructive discussions. We also thank Art Frankel and Morgan Moschetti for thoughtful reviews of the manuscript. This work was done to support the NEHRP Recommended Provisions for Seismic Regulations building codes for American Samoa. 


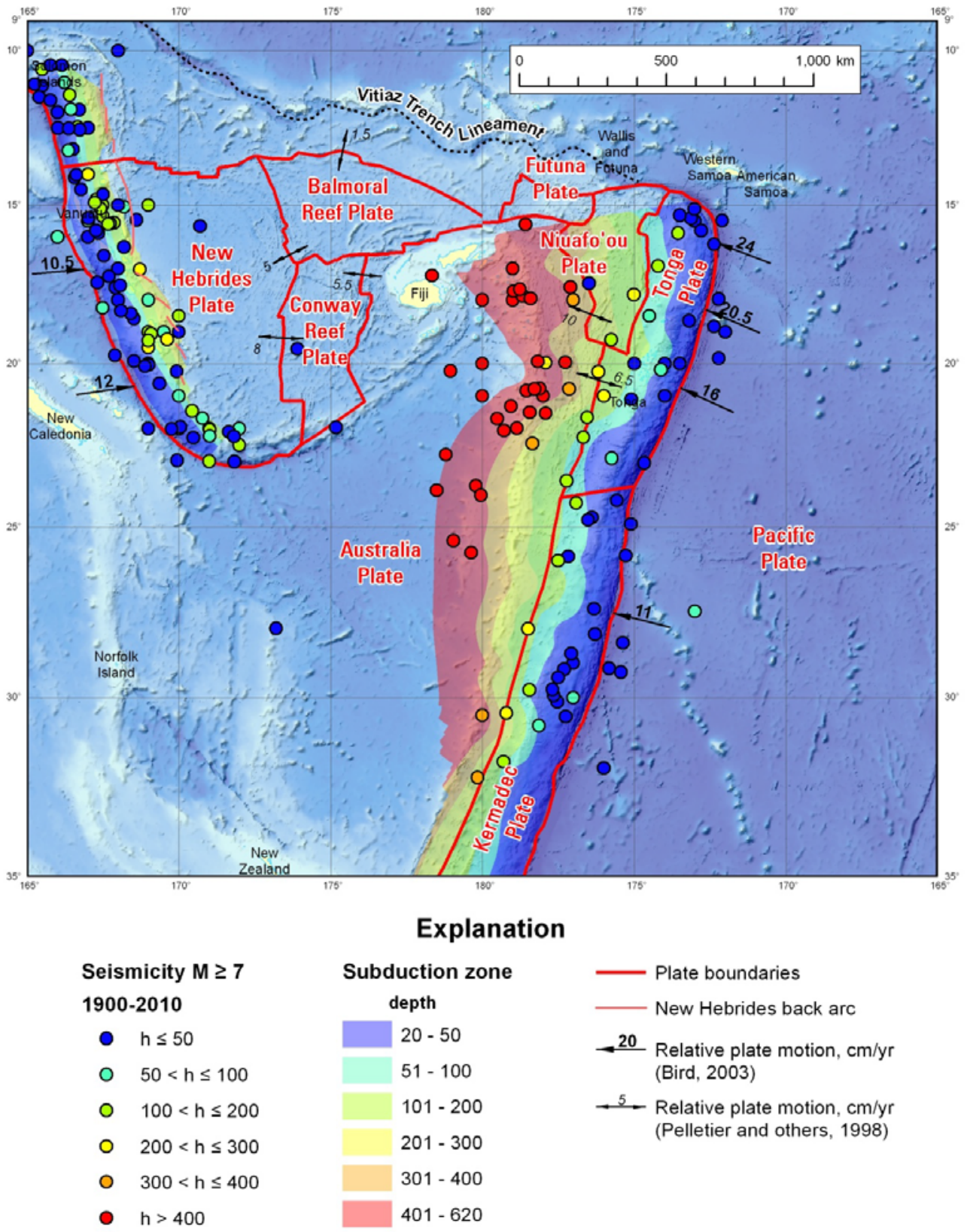

Figure 1. Map showing faults and large earthquakes $M \geq 7$ since 1900 , depth contours of subducing slab (Hayes and others, 2011) and plate tectonic features and slip rates (from Pelletier and others,1998; and Bird, 2003). ( $h$, depth of the earthquake in kilometers; $\mathrm{cm} / \mathrm{yr}$, centimeters per year) 


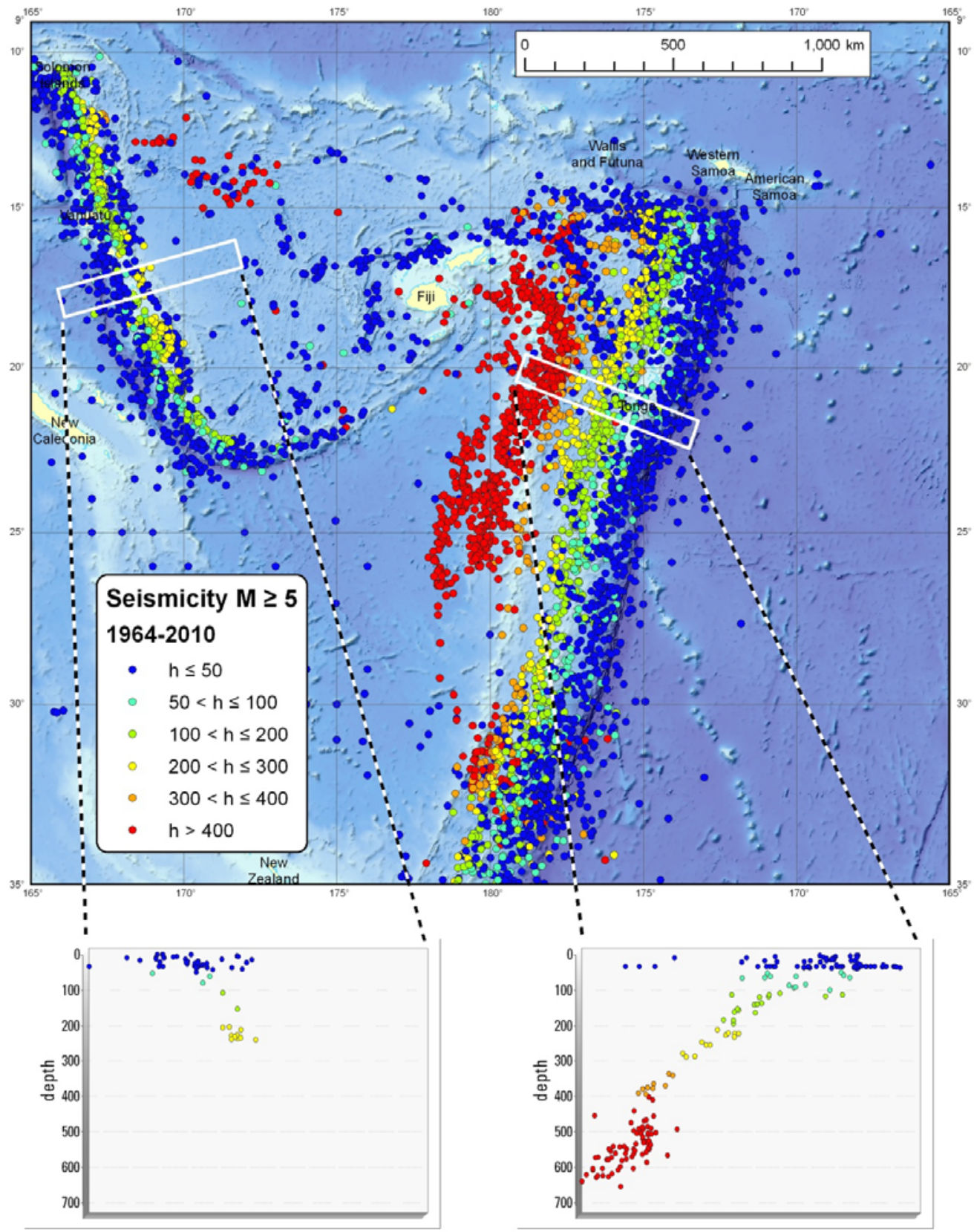

Figure 2. Map showing $M \geq 5$ earthquakes since 1964, color-coded by depth and cross sections across the Tonga and New Hebrides (Vanuatu) subducting slabs. ( $h$, depth of the earthquake in kilometers) 


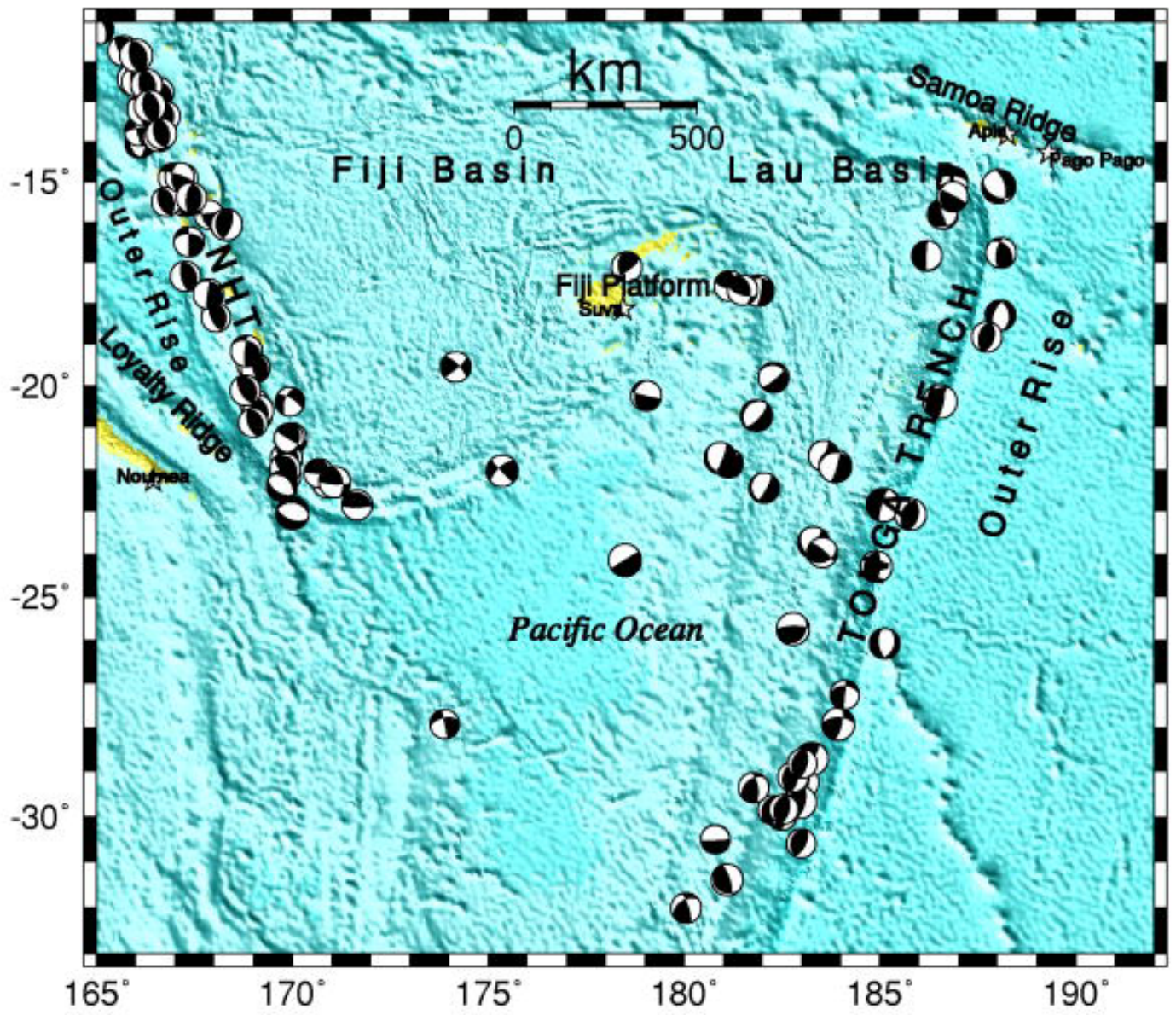

Figure 3. Focal mechanisms from Global Centroid-Moment Tensor Project (http://www.globalcmt.org/) Bathymetry from GMT (Wessel and Smith, 2004). (km, kilometers) 


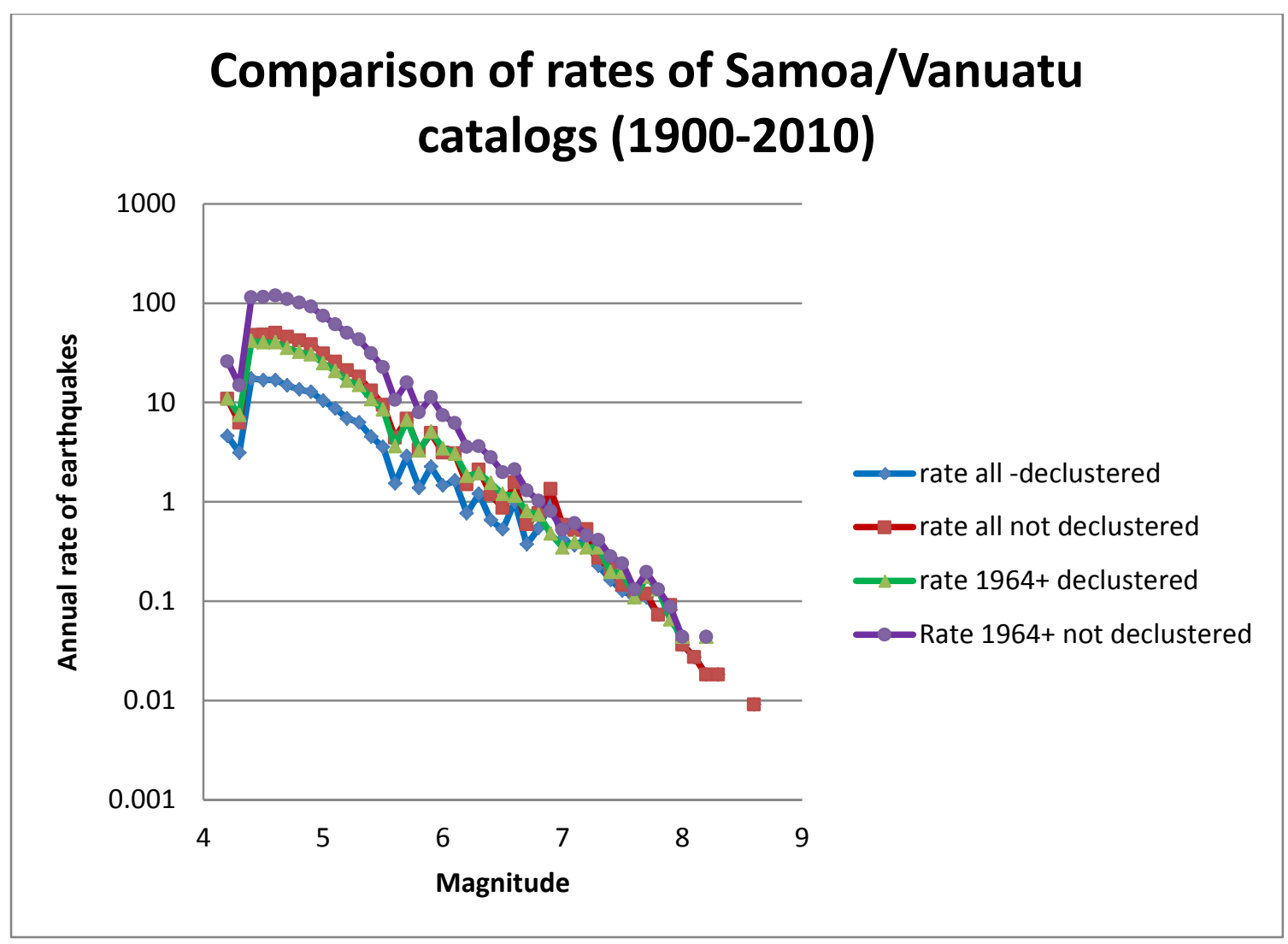

Figure 4. Magnitude-frequency plot showing annual rates of earthquakes in the catalog we developed in this paper for the time periods of 1900-2010 and 1964-2010. We use the full catalog of earthquakes and decluster the catalog to remove dependent events (not declustered). 


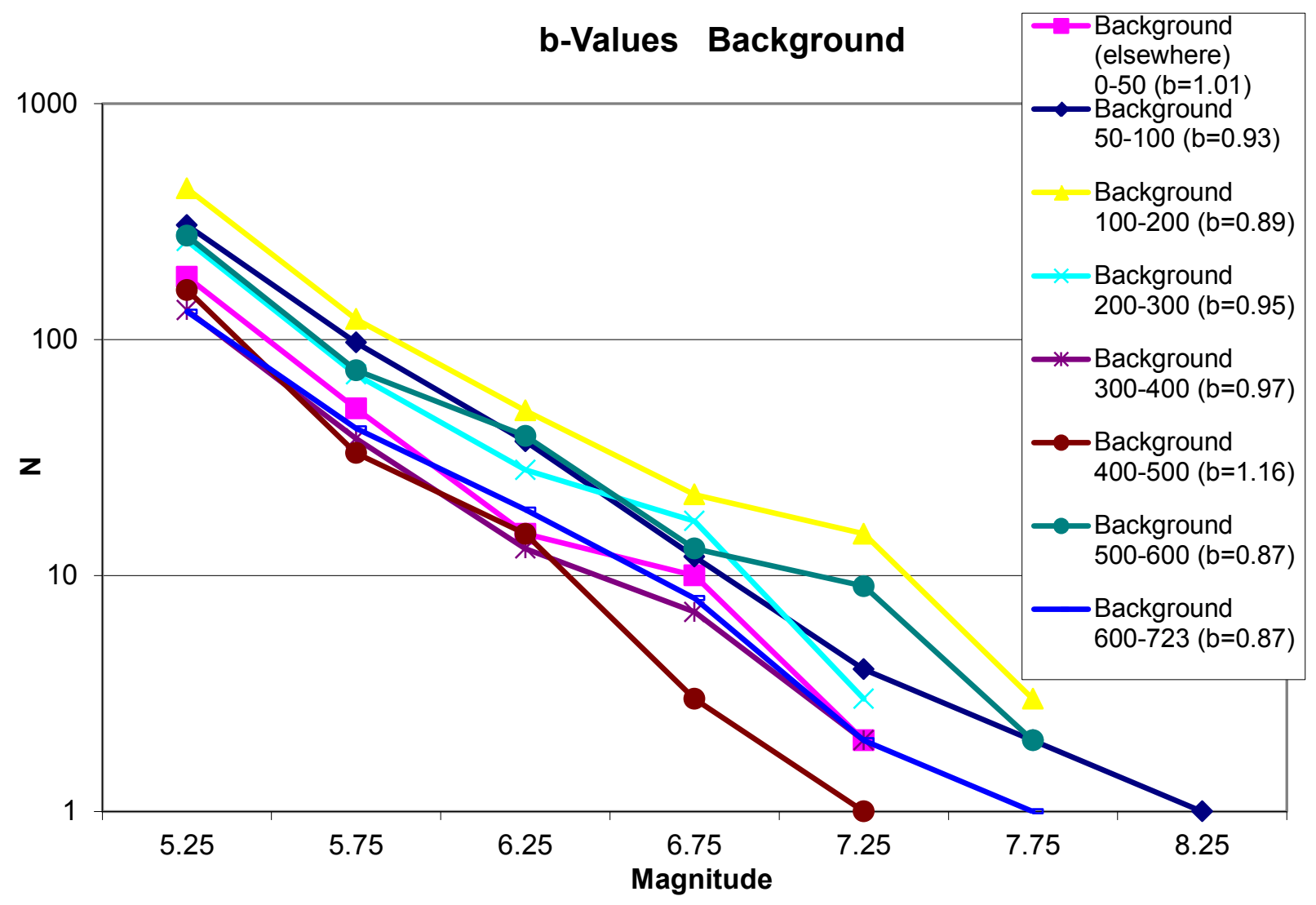

Figure 5. Magnitude-frequency plot showing cumulative number of earthquakes exceeding each magnitude for different depth levels (coded by color). 


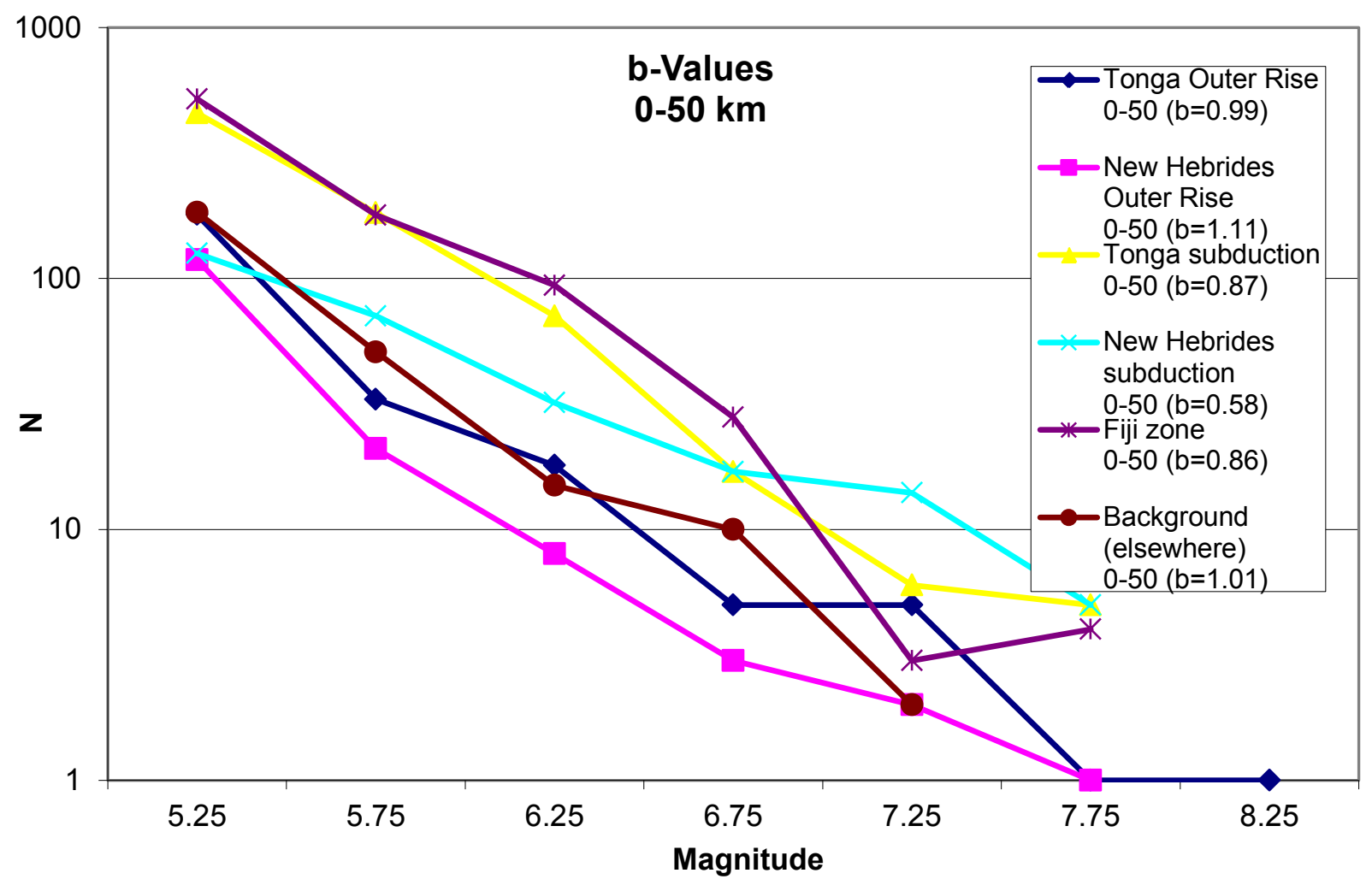

Figure 6. Magnitude-frequency distribution for the primary shallow-source models ( $0-50 \mathrm{~km}$ depth) showing the cumulative number of earthquakes exceeding each magnitude. (km, kilometers) 


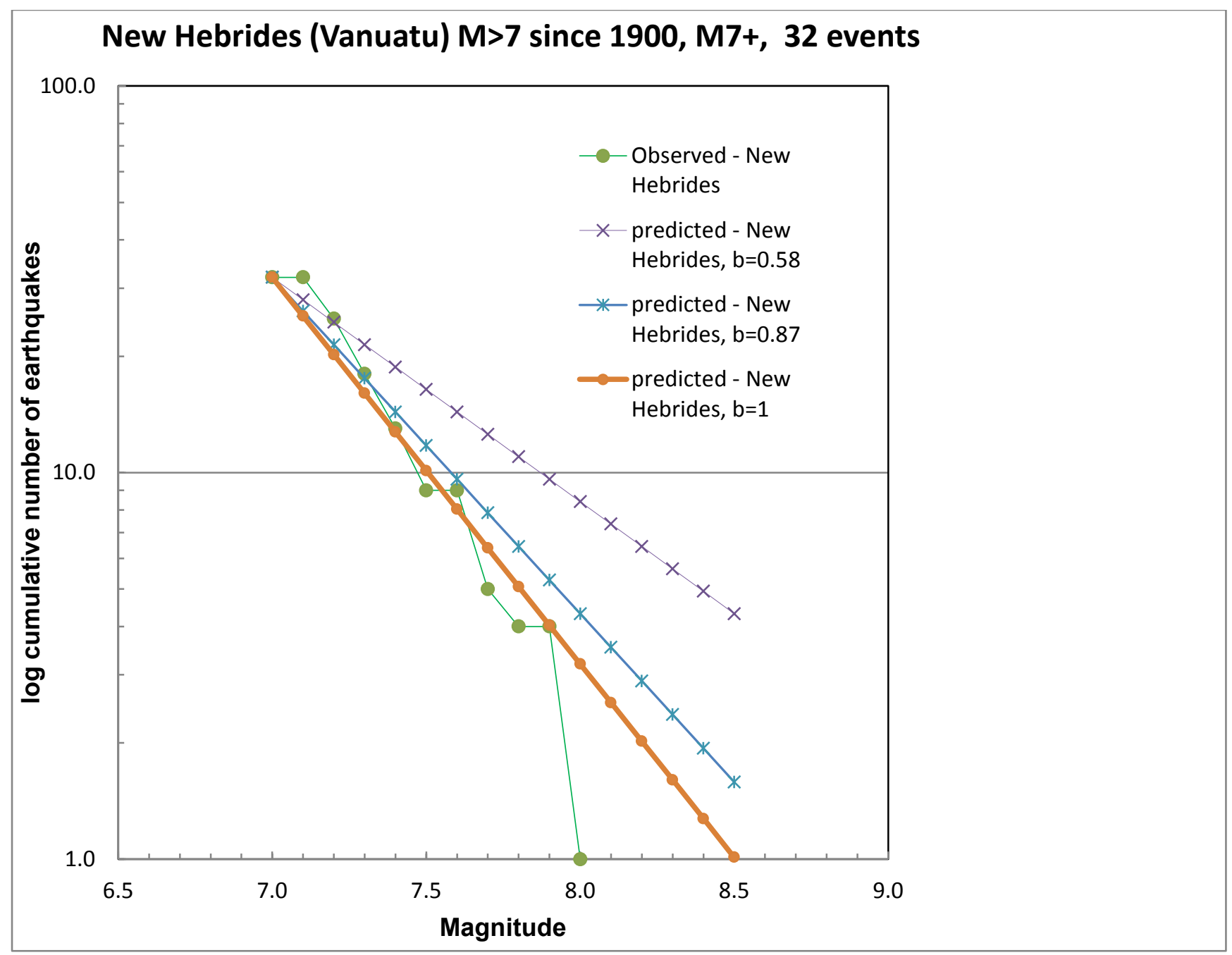

Figure 7. Magnitude-frequency plot for New Hebrides region showing fits to the observed data for $M \geq 7$ events since 1900. 


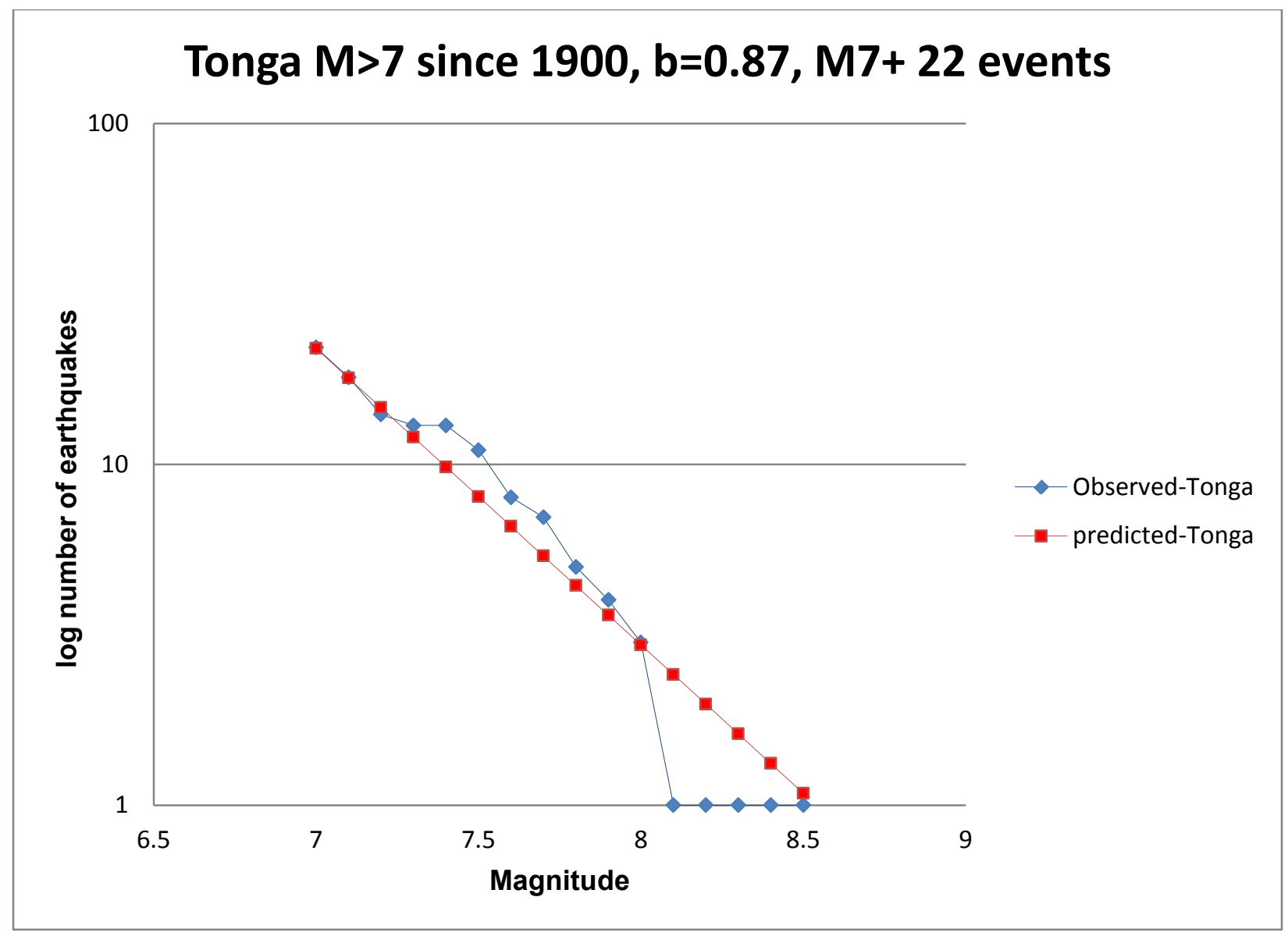

Figure 8. Magnitude-frequency plot showing the fit to the observed Tonga earthquake data $M>7$ since 1900. 


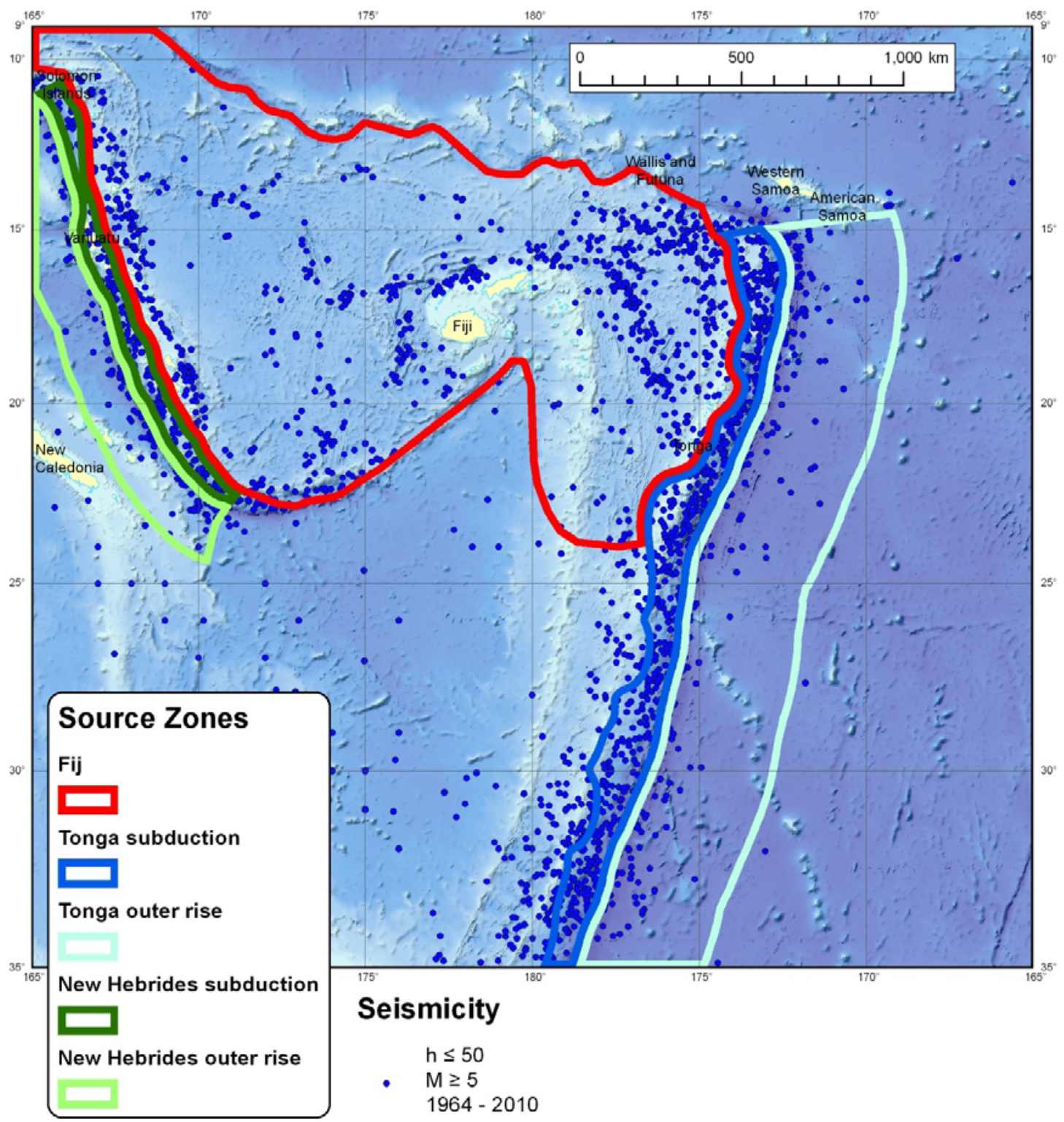

Figure 9. Map showing location of sources used in constructing the seismic hazard maps. ( $\mathrm{km}$, kilometers, $\mathrm{h}$, depth of the earthquake in kilometers) 

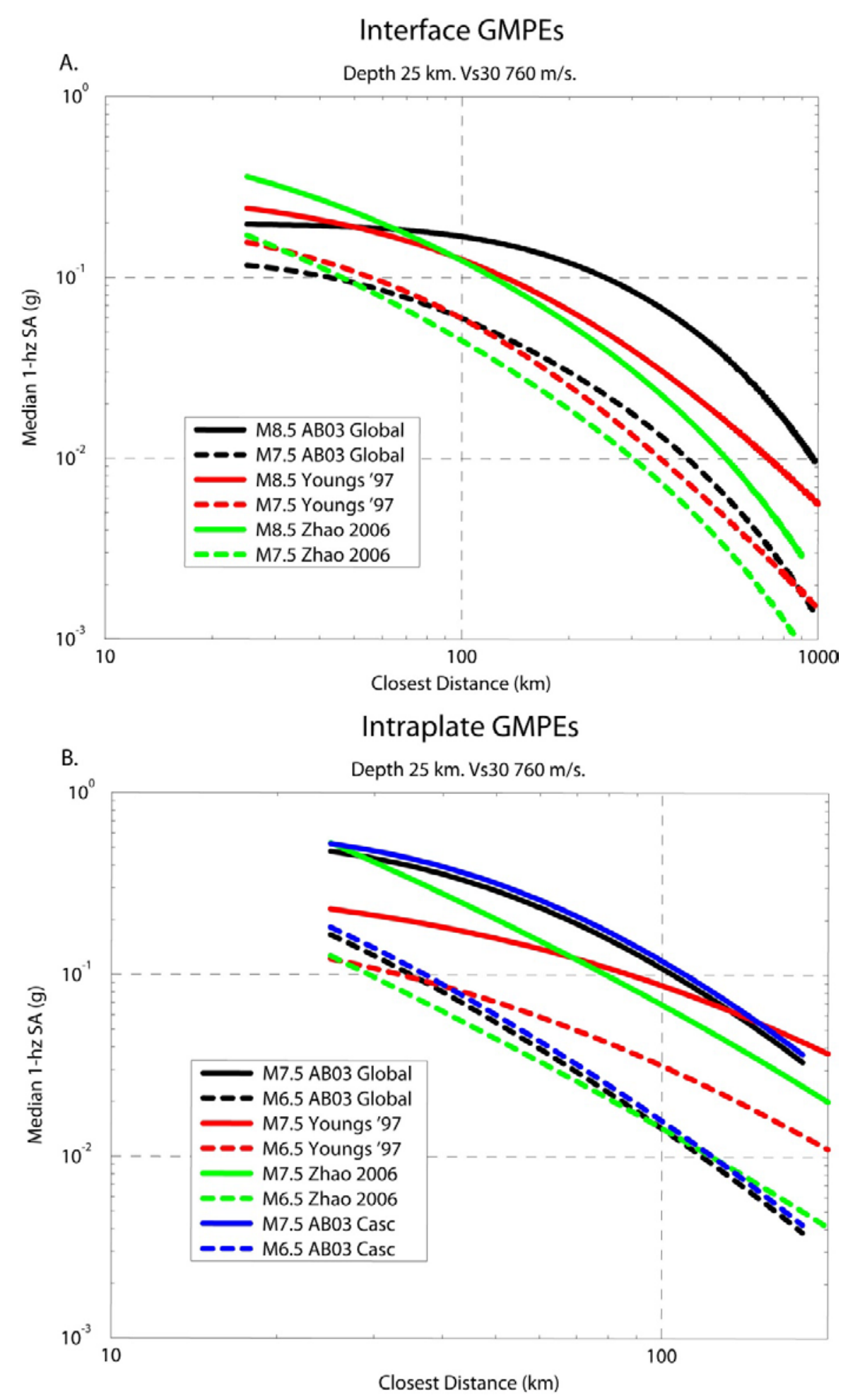

Figure 10. Plot showing four 1-Hertz Spectral acceleration (SA) ground motion prediction equations for $M 6.5$ and M 7.5 earthquakes on the $A$ interface and the $B$ intraplate sources. (GMPE, Ground Motion Prediction Equation; $\mathrm{km}$, kilometers; $\mathrm{m} / \mathrm{s}$, meters per second; $\mathrm{Vs} 30$, shear wave velocity in the upper 30 meters) 

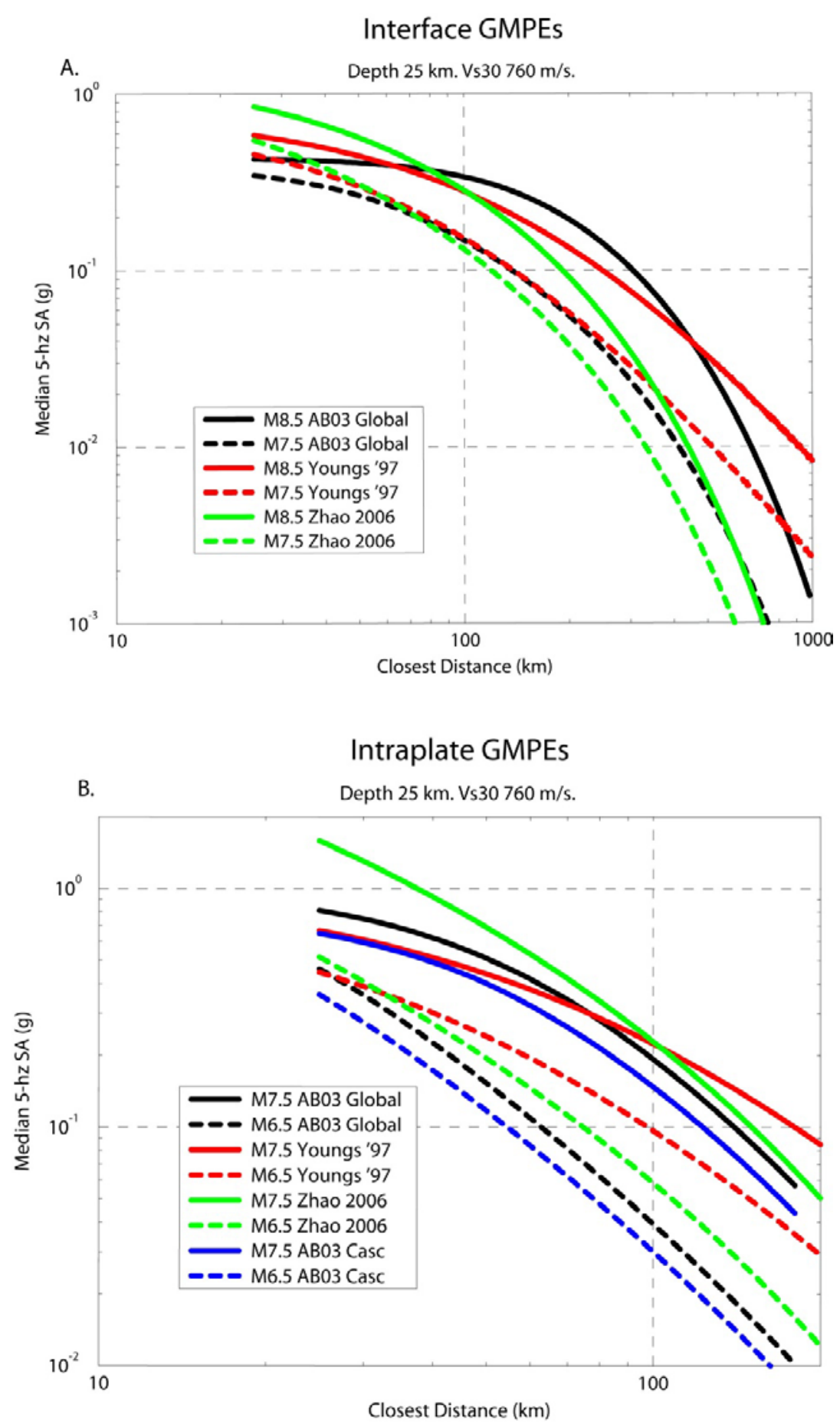

Figure 11. Plot showing four $5 \mathrm{~Hz}$ Spectral acceleration (SA) ground motion prediction equations for $\mathrm{M} 6.5$ and $\mathrm{M}$ 7.5 earthquakes on the $A$ interface and the $B$ intraplate sources. (GMPE, Ground Motion Prediction Equation; km, kilometers; $\mathrm{m} / \mathrm{s}$, meters per second; $\mathrm{Vs} 30$, shear wave velocity in the upper 30 meters) 


\section{Interface GMPEs}
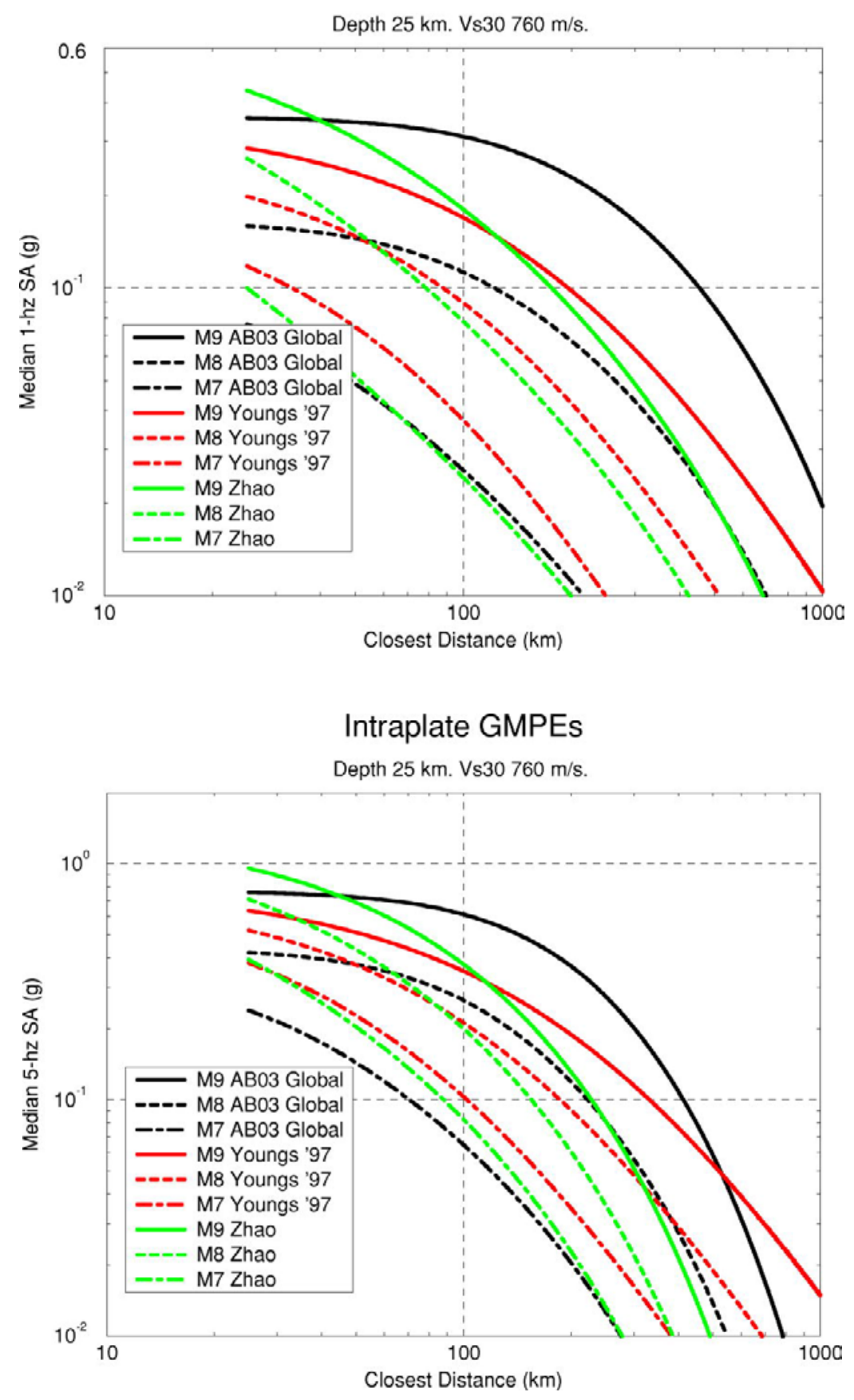

Figure 12. Comparison of the Atkinson and Boore (2003) global, Youngs and others (1997), and Zhao and others (2006) intraplate 5-Hertz (Hz) (lower plot) and interface 1-Hz (upper plot) spectral accelerations. (GMPE, Ground Motion Prediction Equation; km, kilometers; m/s, meters per second; Vs30, shear wave velocity in the upper 30 meters) 
Intraplate Source M7.5. Vary Depth

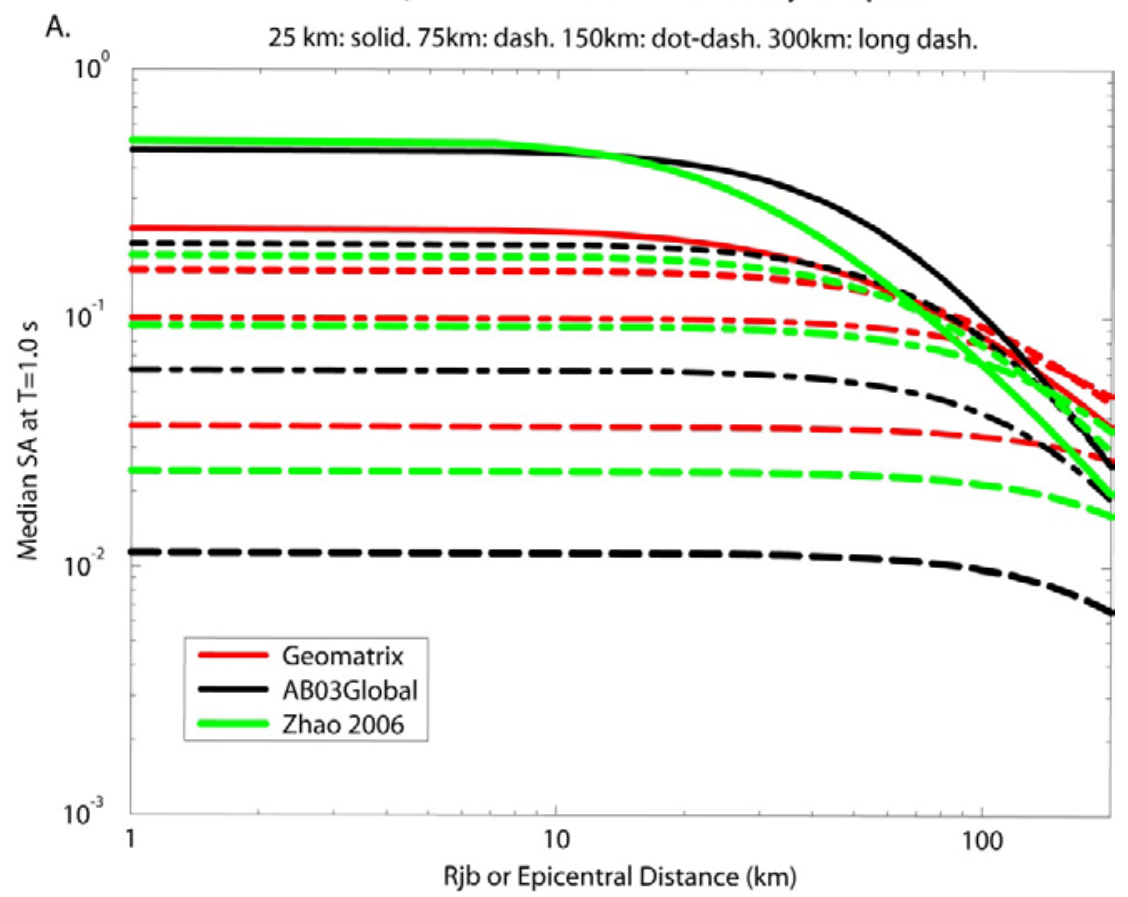

Intraplate Source M7.5. Vary Depth

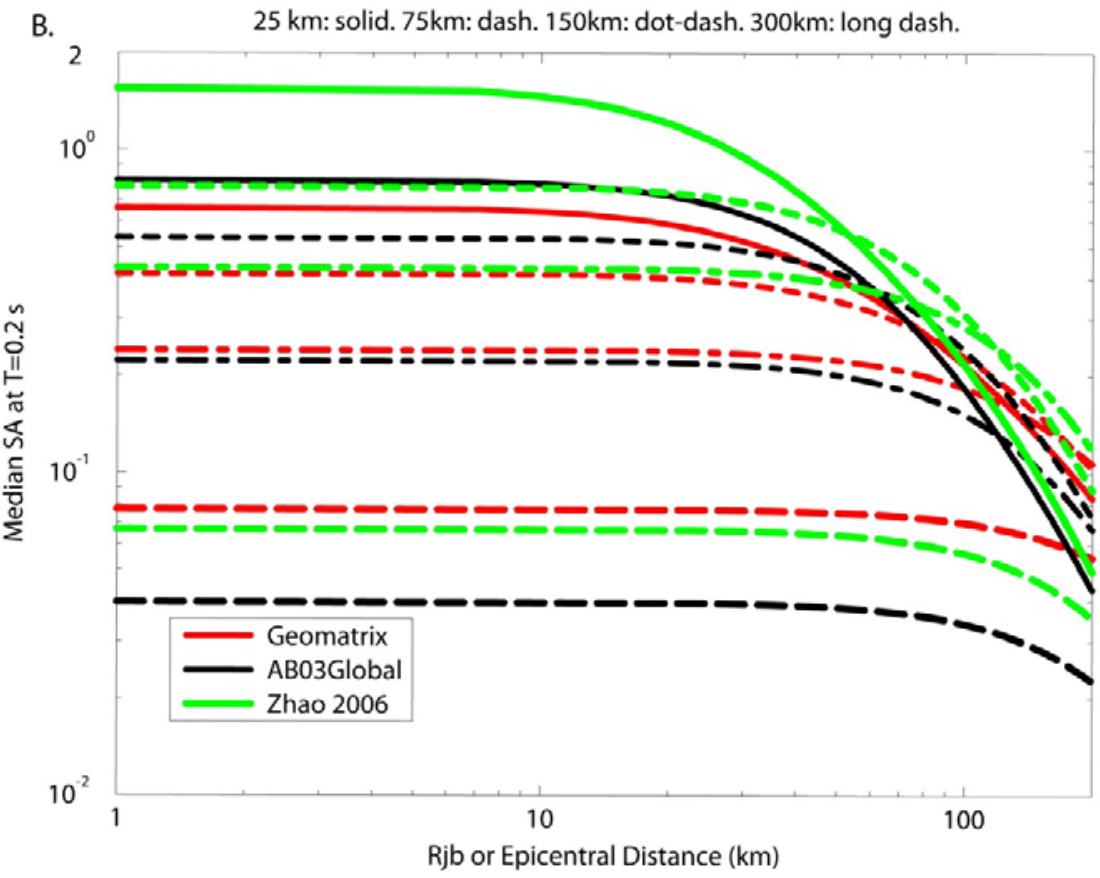

Figure 13. Plot showing three Spectral acceleration ground motion prediction equations (A. $1 \mathrm{Hertz}(\mathrm{Hz})$, B. $5 \mathrm{~Hz})$ for an M 7.5 intraplate earthquake as a function of depth. (km, kilometers; the vertical axis shows the median spectral acceleration for period ( $\mathrm{T})$ of 1.0 and 0.2 seconds) 

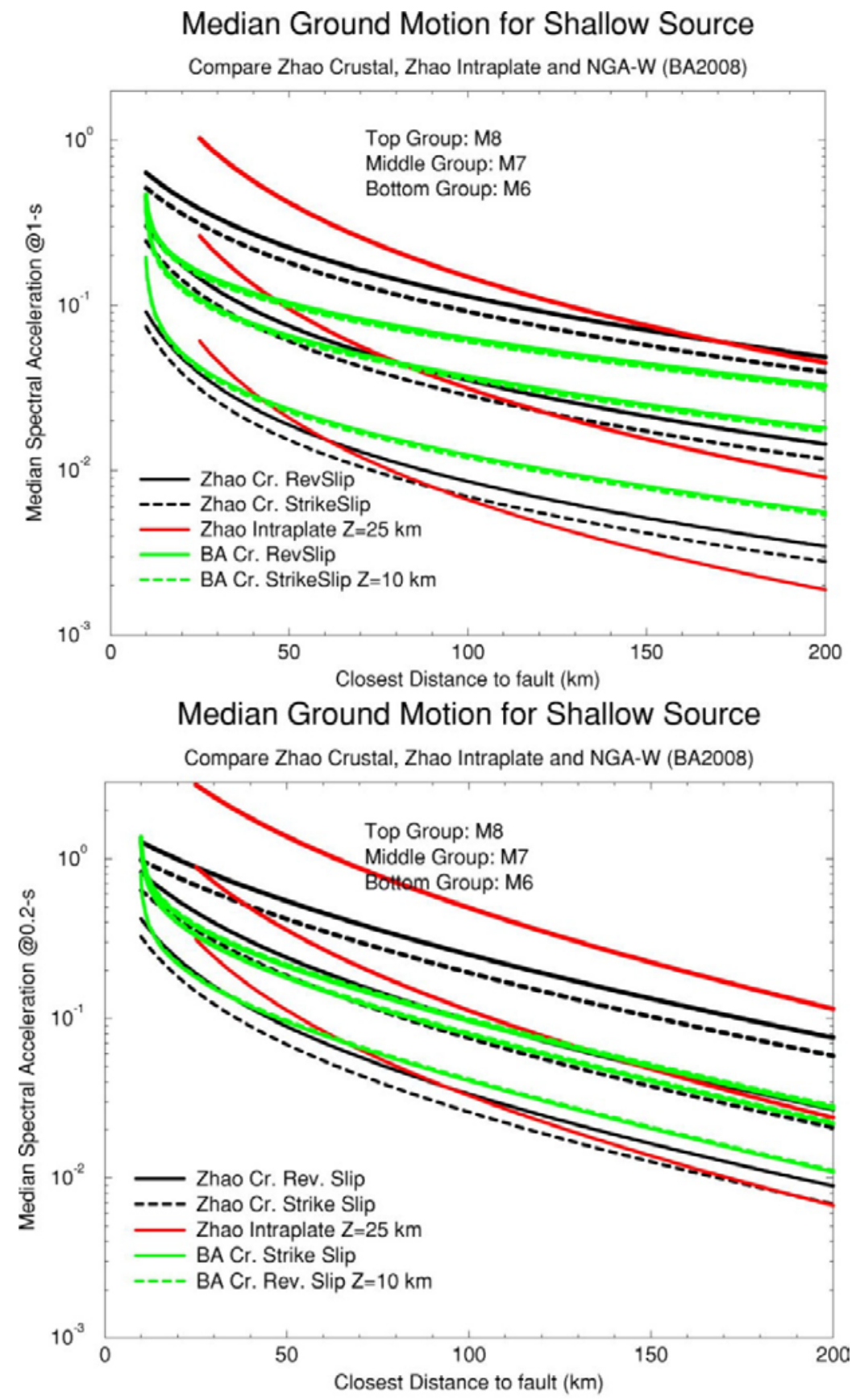

Figure 14. Ground motion prediction equations showing spectral acceleration at 1 second (sec) (1 Hertz $(\mathrm{Hz}))$ and $0.2 \mathrm{~s}(5 \mathrm{~Hz})$ spectral acceleration for distances up to $200 \mathrm{~km}$ for the Zhao crustal equations, Zhao intraplate, and NGA-Boore and Atkinson (2008) crustal models. (km, kilometers) 
Zhao et al. GMPE
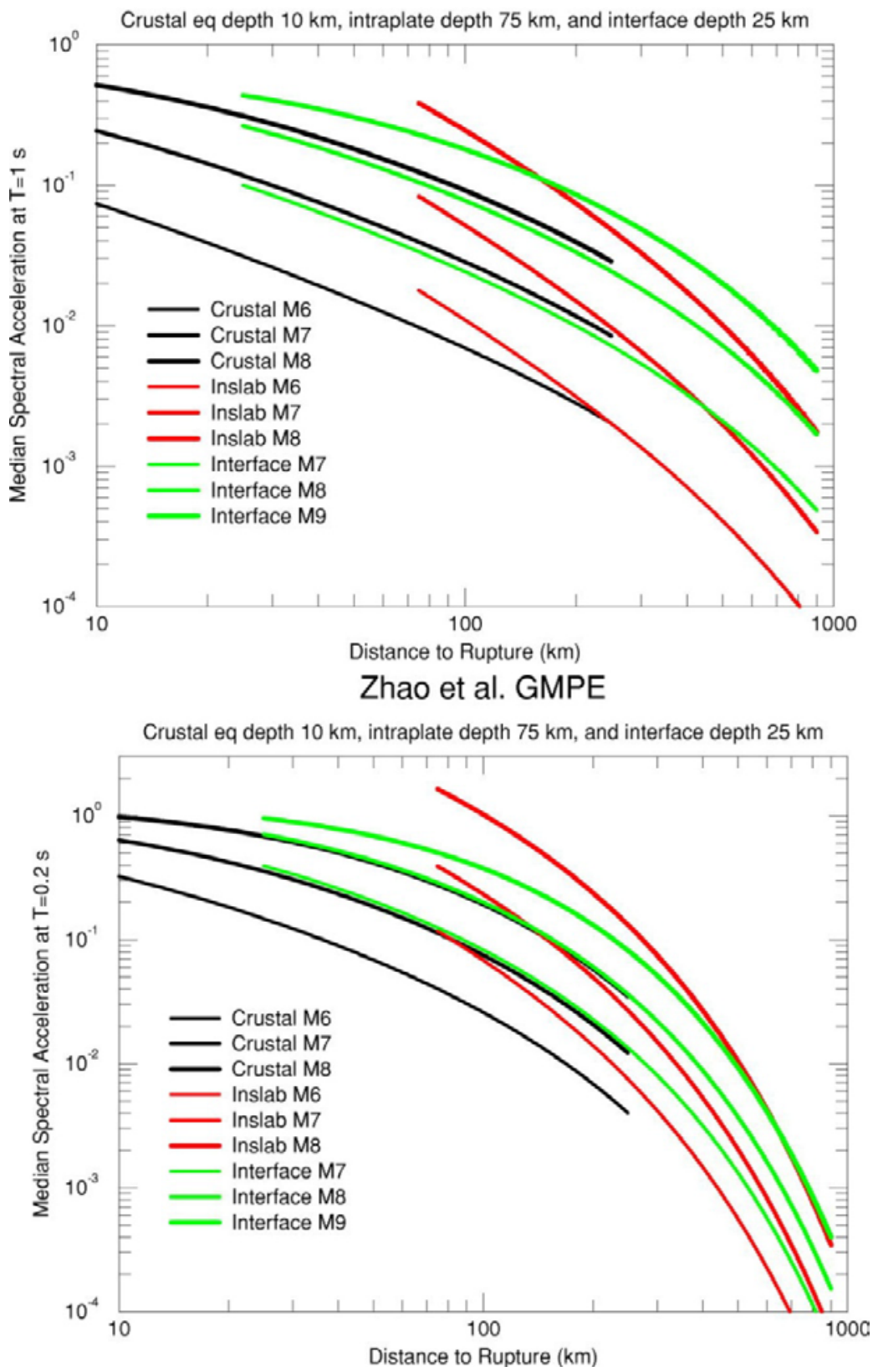

Figure 15. Ground motion prediction equations showing spectral acceleration at 1 second (sec) (1 Hertz $(\mathrm{Hz}))$ and $0.2 \mathrm{~s}(5 \mathrm{~Hz})$ spectral acceleration for distances up to $200 \mathrm{~km}$ for the Zhao crustal equations, Zhao intraplate, and NGA-Boore and Atkinson (2008) crustal models. (km, kilometers). The Zhao et al. GMPE represents the Zhao and others (2006) Ground motion prediction equation discussed in the text. 
Source and Receiver Locations

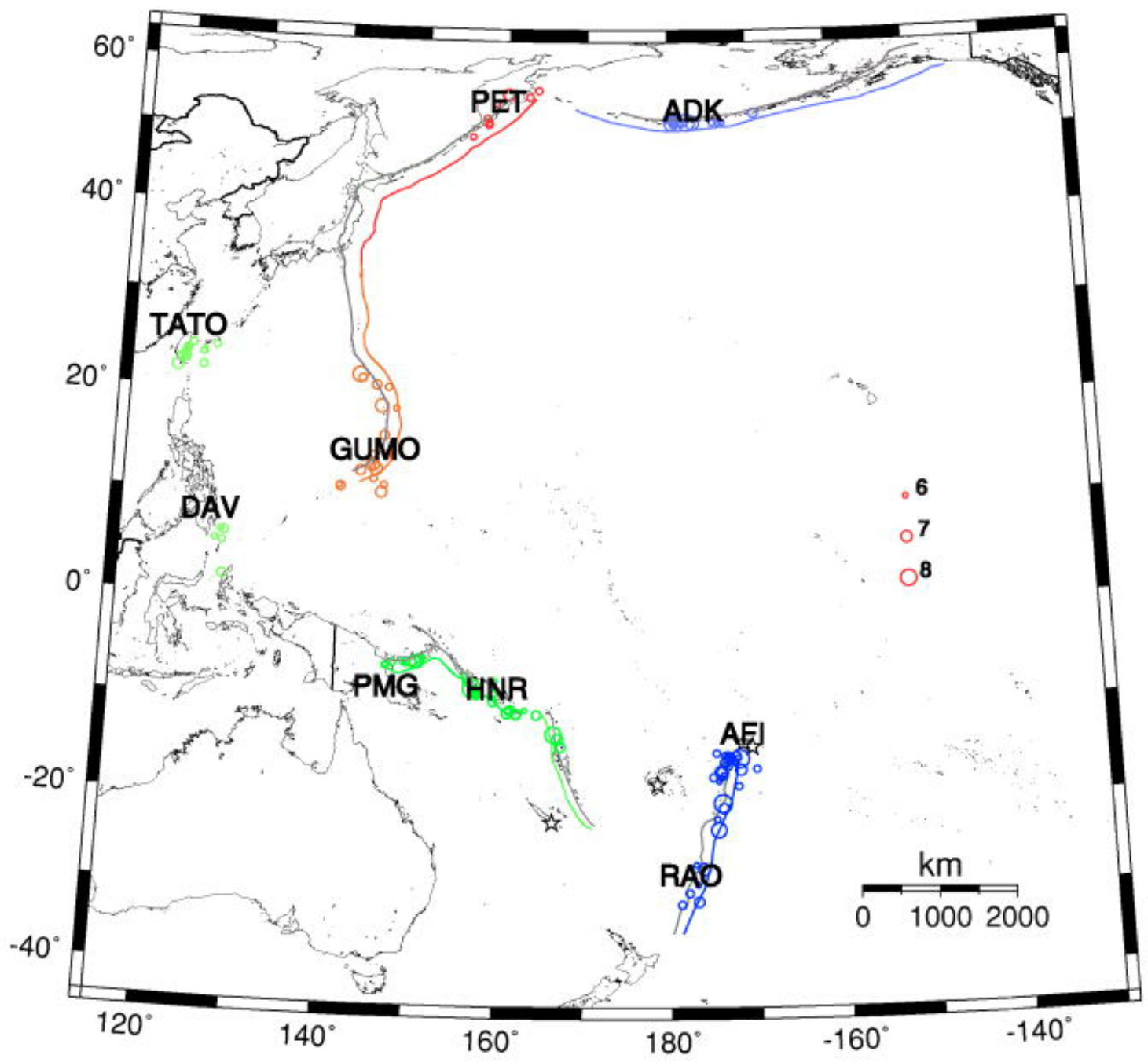

Figure 16. Map showing earthquakes $M>6$ and recording stations used in determining weights applied for the ground motion prediction equations. (km, kilometers) 
$A$

Zhao and others 1 Hertz spectral acceleration Depth=30 km, Vs30 $600 \mathrm{~m} / \mathrm{s}$

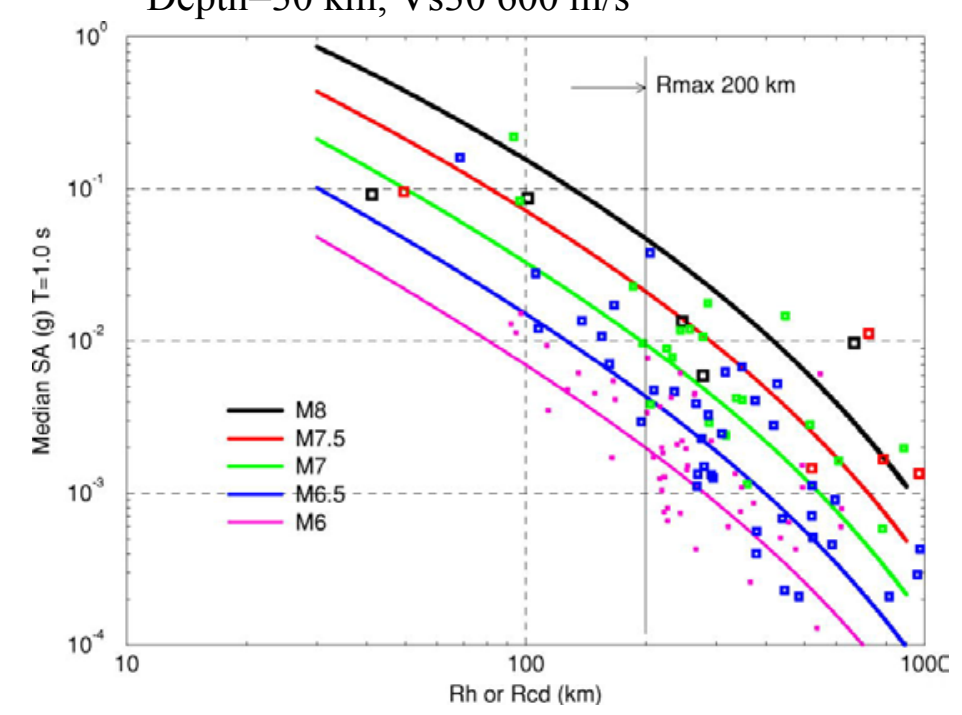

$B$

Zhao et al. Intraslab \& GDSN Data

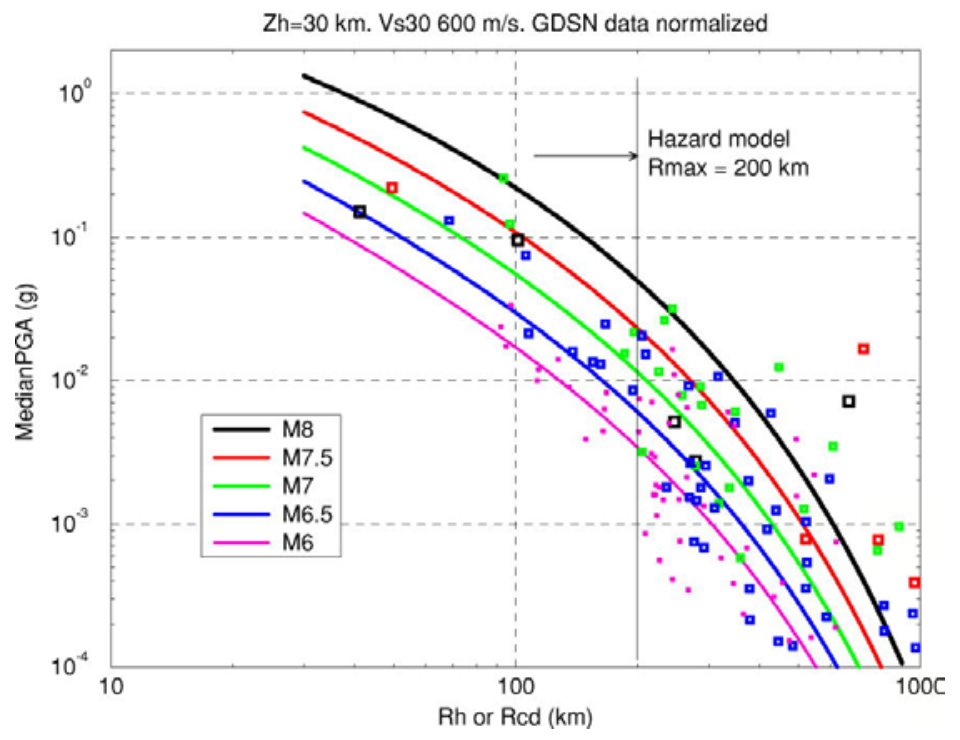

Figure 17. Graph showing the Zhao and others 2006 intraslab ground motion model with Pacific strong motion data for $A, 1 \mathrm{~Hz}$ Spectral acceleration (SA) and B, Peak horizontal ground acceleration (PGA). (GDSN, Global Digital Seismic Network; km, kilometers; $\mathrm{m} / \mathrm{s}$, meters per second). The Zhao et al. model represents the Zhao and others (2006) ground motion prediction equation. 

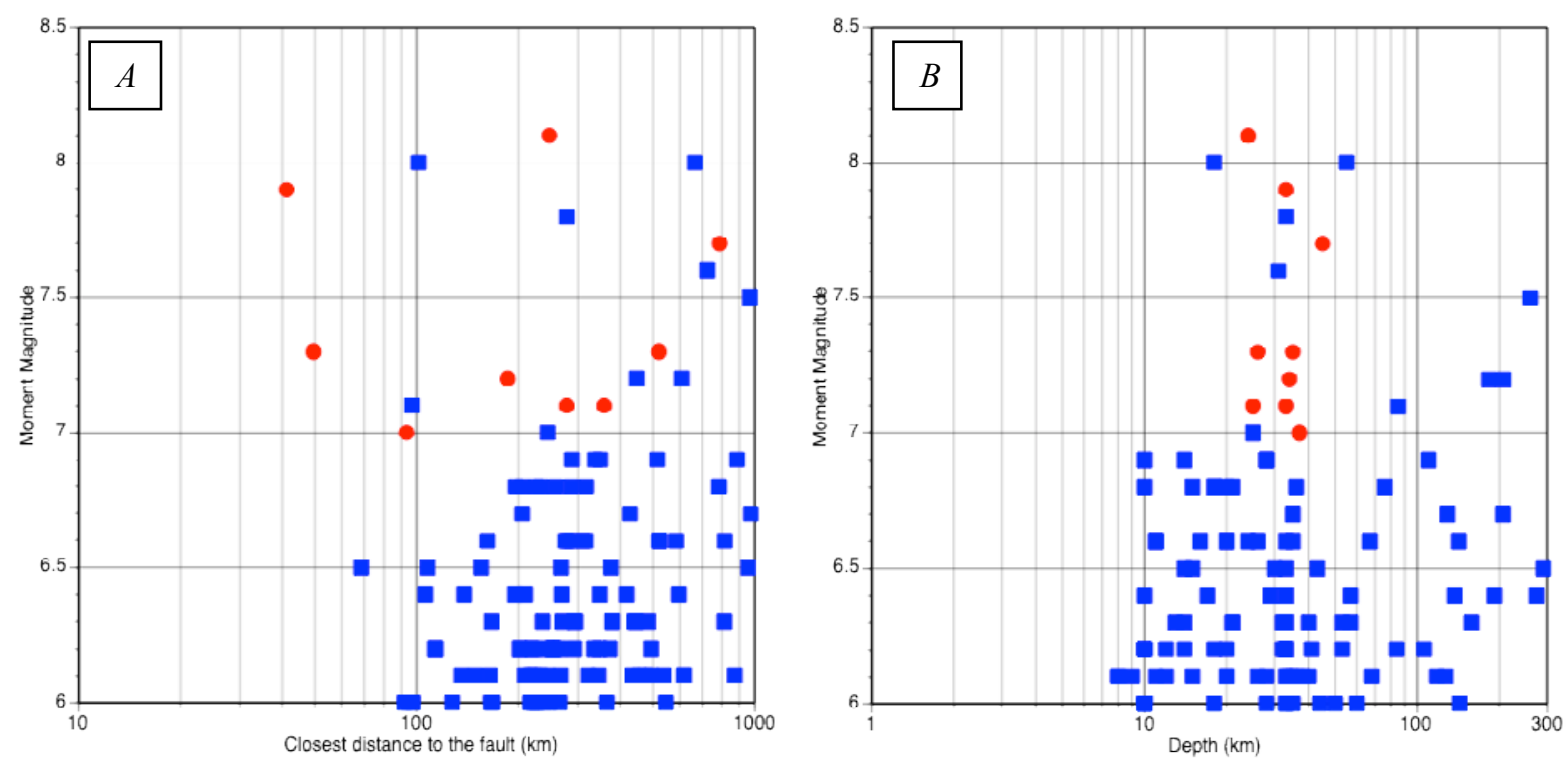

Figure 18. Magnitude distribution versus $A$ distance and $B$ depth. Red circles represent interface events and blue squares represent intraslab events. ( $\mathrm{km}$, kilometers) 

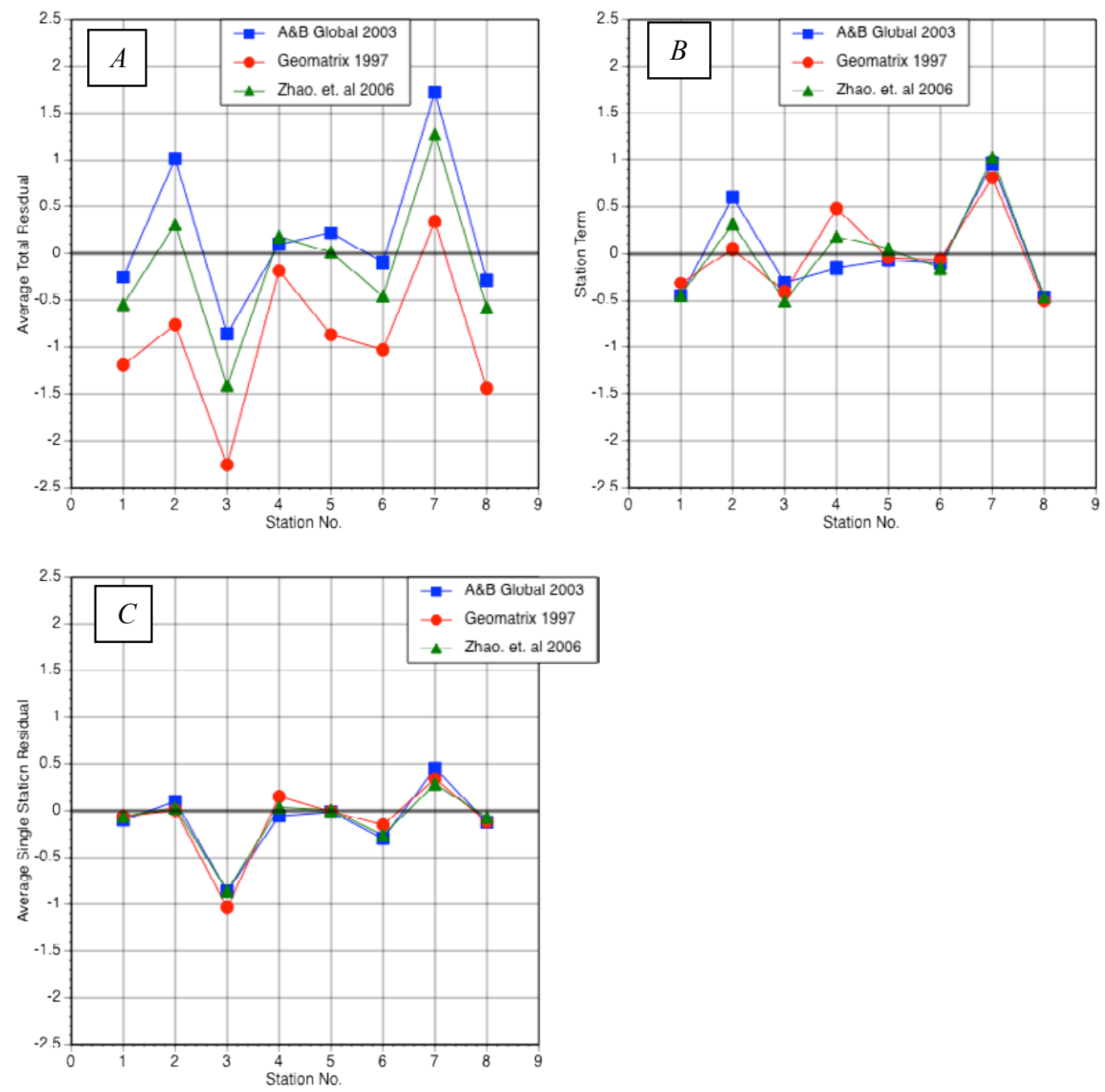

Figure 19. Peak horizontal Ground Acceleration (PGA) residuals at each station in natural log units. Station Numbers: 1 is ADK, 2 is AFI, 3 is DAV, 4 is GUMO, 5 is HNR, 6 is PET, 7 is RAO, and 8 is TATO. A, average total residual for each station; $B$, station term obtained by computing approximate mean residual between ground-motion data and GMPE at a given station; $C$, average single station residual at each station, obtained by subtracting the station term and systematic offset $\mathrm{C}_{1}$ from the total residual. (km, kilometers) 

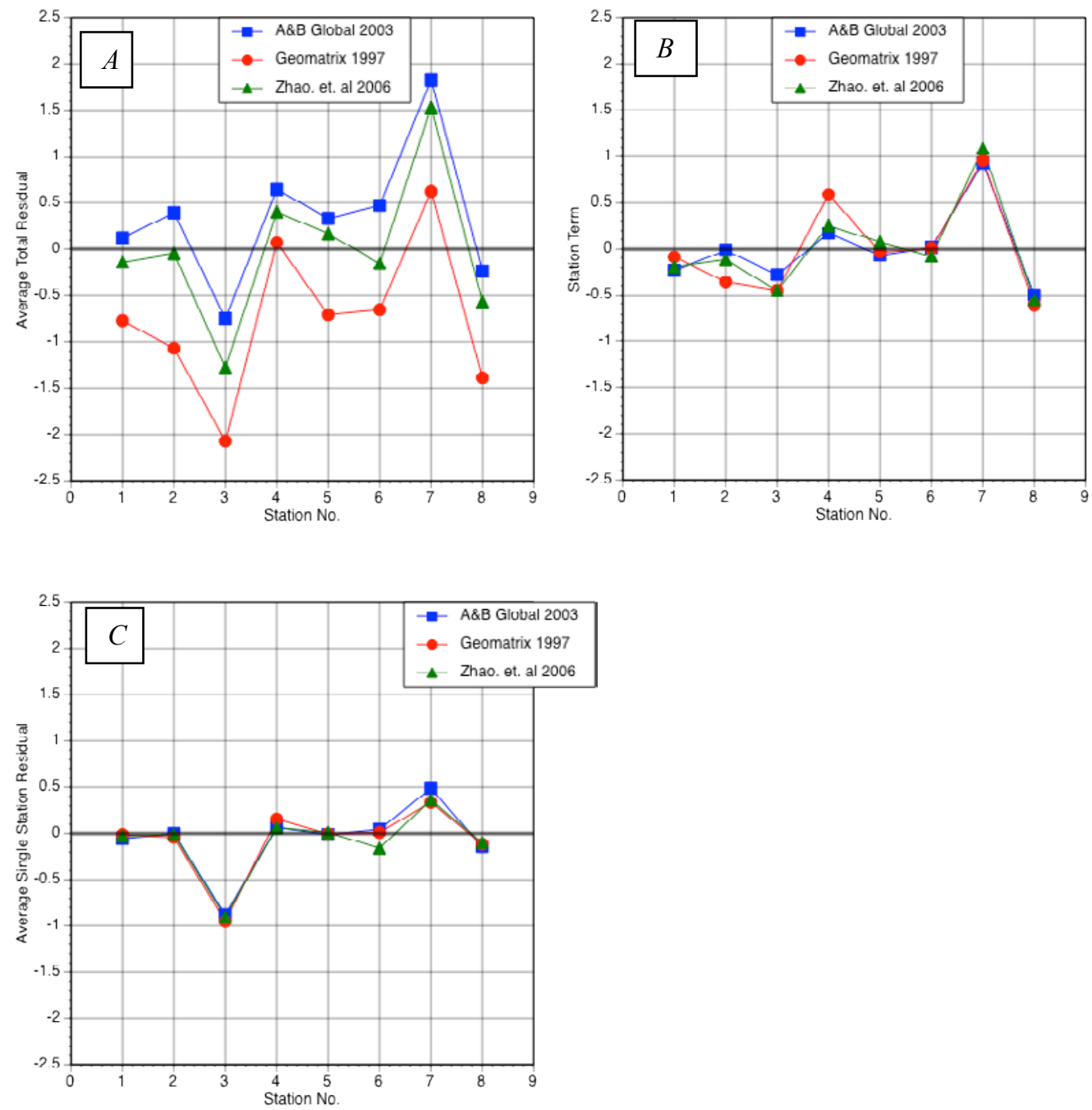

Figure 20. Five Hertz residuals at each strong motion station based on natural log units. Station numbers are as follows: 1 is ADK, 2 is AFI, 3 is DAV, 4 is GUMO, 5 is HNR, 6 is PET, 7 is RAO, and 8 is TATO. A, average total residual for each station; $B$, station term obtained by computing approximate mean residual between groundmotion data and GMPE at a given station; $C$, average single station residual at each station, obtained by subtracting the station term and systematic offset $\mathrm{C}_{1}$ from the total residual. 

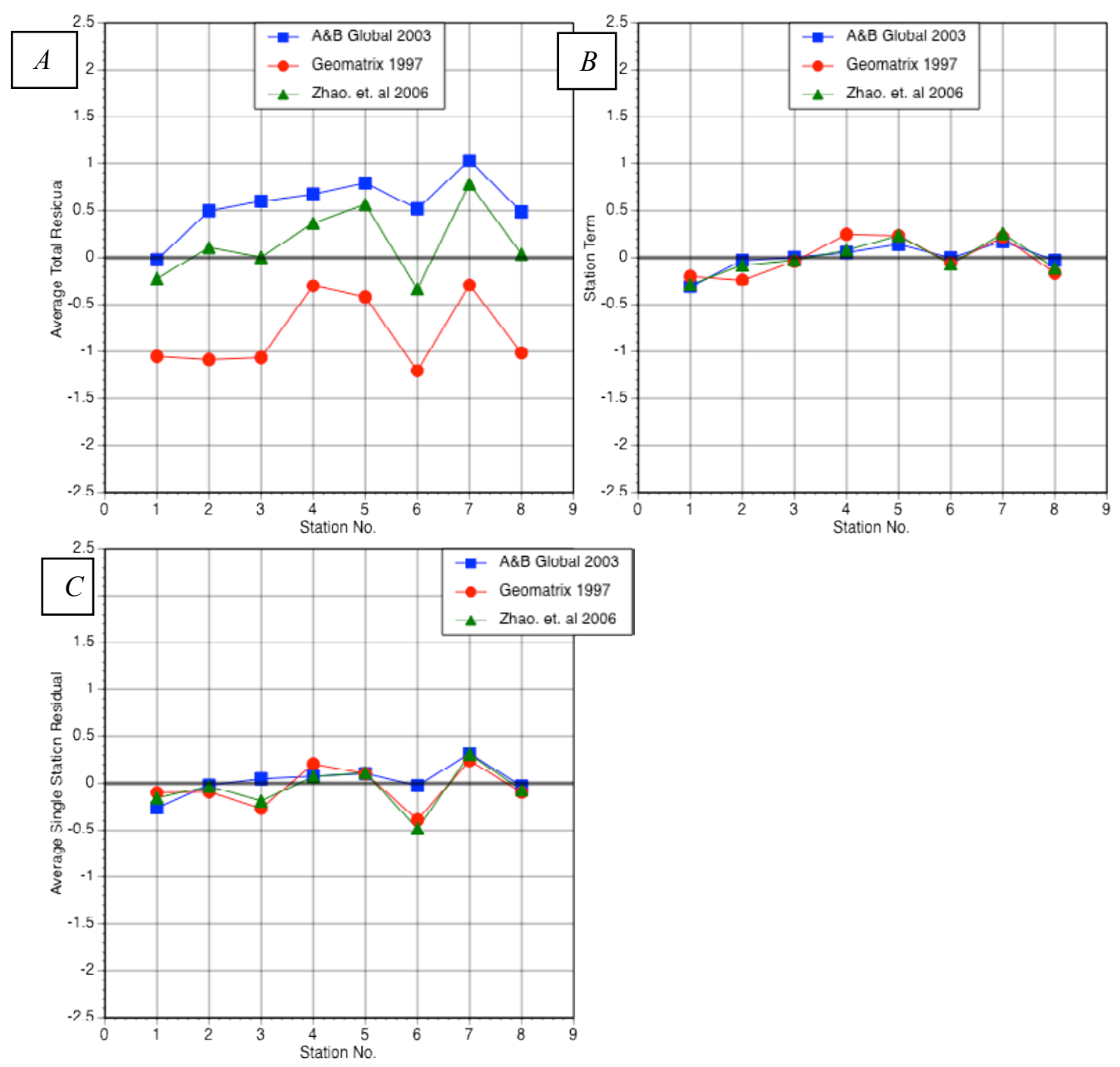

Figure 21. One Hertz residuals at each station based on natural log units. Station numbers are as follows: 1 is ADK, 2 is AFI, 3 is DAV, 4 is GUMO, 5 is HNR, 6 is PET, 7 is RAO, and 8 is TATO. $A$, average total residual for each station; $B$, station term obtained by computing approximate mean residual between ground-motion data and GMPE at a given station; $C$, average single station residual at each station, obtained by subtracting the station term and systematic offset $\mathrm{C}_{1}$ from the total residual. 

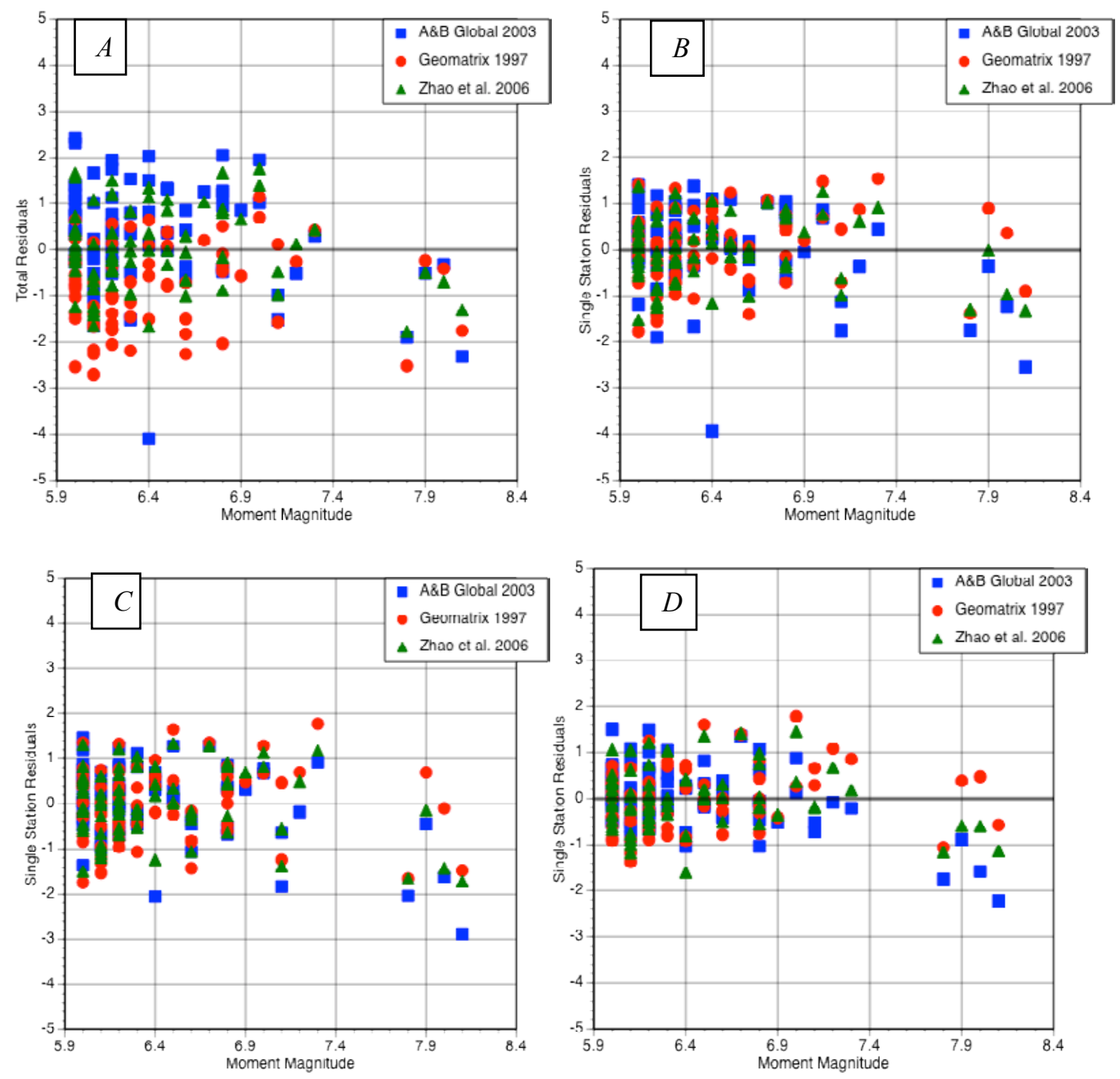

Figure 22. $A$, correlated residual Peak horizontal ground acceleration(PGA) versus moment magnitude; $B$, uncorrelated or single station residual PGA versus moment magnitude; $C$, uncorrelated or single station residual $5 \mathrm{Hertz}(\mathrm{Hz})$ versus moment magnitude; $D$, uncorrelated or single station residual $1 \mathrm{~Hz}$ versus moment magnitude. 

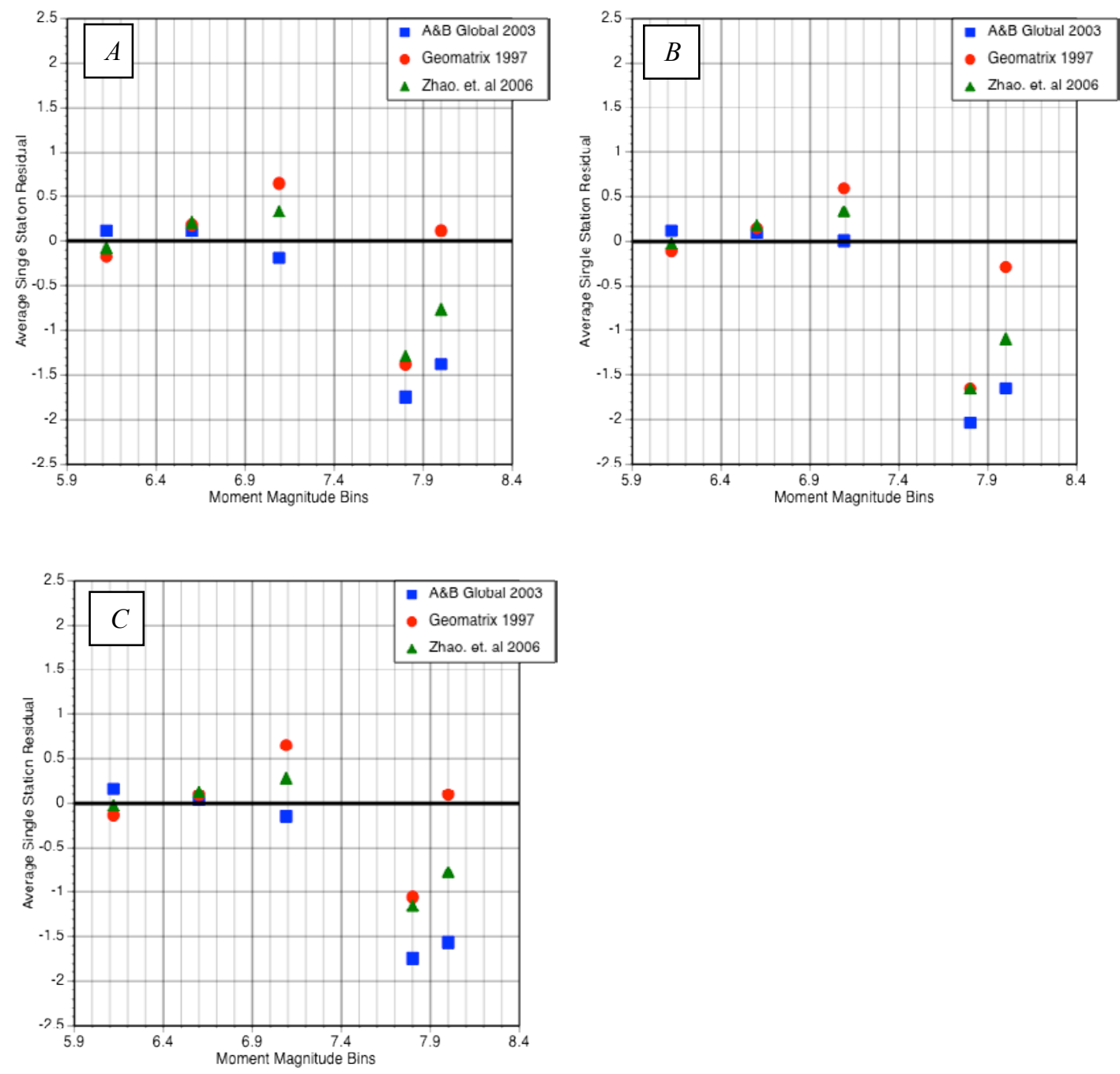

Figure 23. Average single station residuals versus moment magnitude for $A$, peak horizontal ground acceleration (PGA); $B, 5 \mathrm{~Hz}$; and C, $1 \mathrm{~Hz}$ spectral acceleration (SA). 

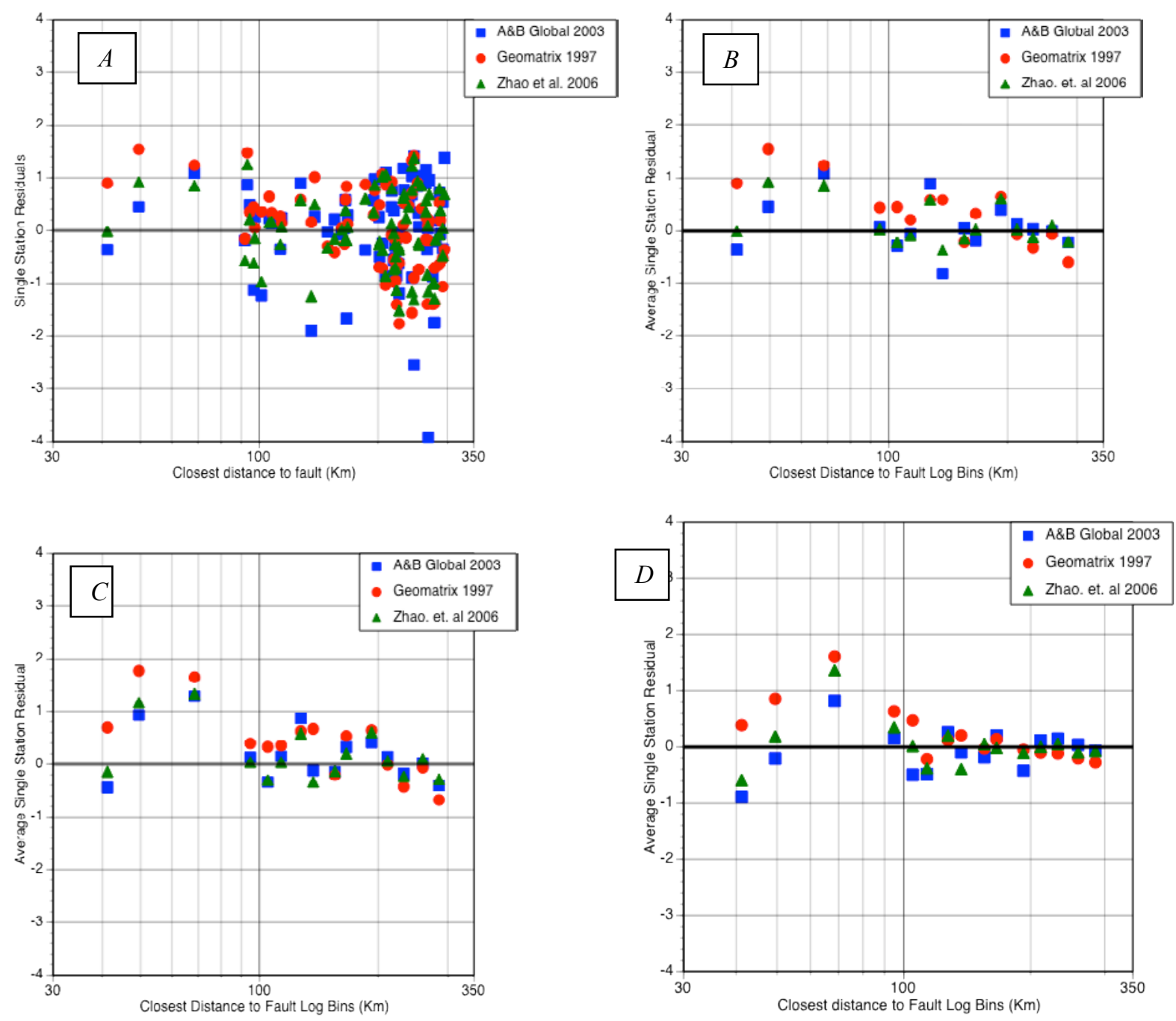

Figure 24. Single station residuals as a function of distance for $A$, peak horizontal ground acceleration (PGA) and average single station residuals versus distance for $B, P G A ; C, 5 \mathrm{~Hz}$; and $D, 1 \mathrm{~Hz}$ spectral acceleration (SA). (km, kilometer) 


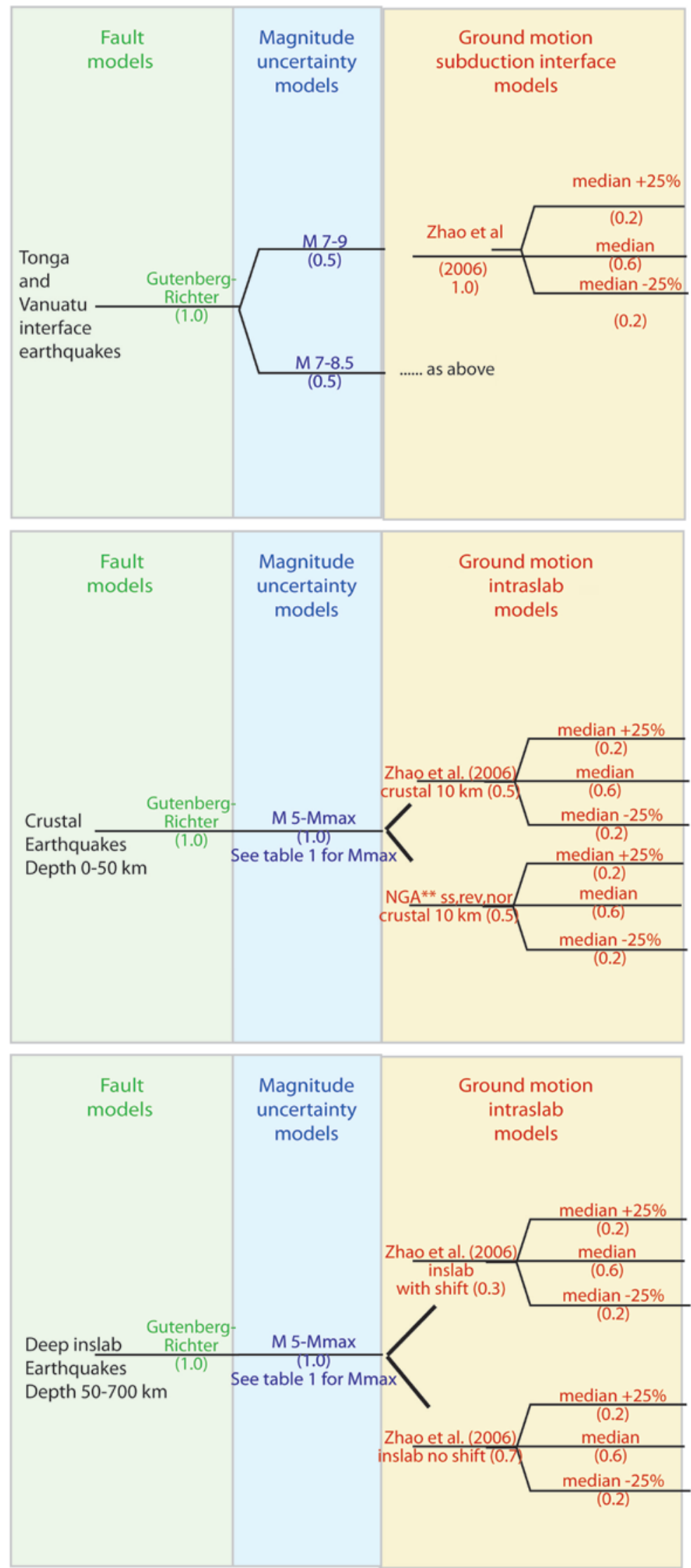

Figure 25. Logic tree for subduction-fault sources. Parameters in this table include some aleatory variability as well as depicted epistemic uncertainty. We treat aleatory variability in ground motion in the hazard code. The historic seismicity defines the Gutenberg- Richter magnitudefrequency distribution. NGA represents the Next Generation Attenuation Relations of Chiou and Youngs (2008), Campbell and Bozorgnia (2008), and Atkinson and Boore (2008). Each of the equations is weighted equally. In zones that include subduction zones, we use 30 percent strike-slip and 70 percent reverse in the groundmotion models. In all other zones, we use half strike-slip and half normal faulting mechanisms in the ground-motion models, based on the moment tensors shown in figures 3 and 24 . (km, kilometers; ss, strike-slip mechanism; rev, reverse mechanism; nor, normal mechanism) 


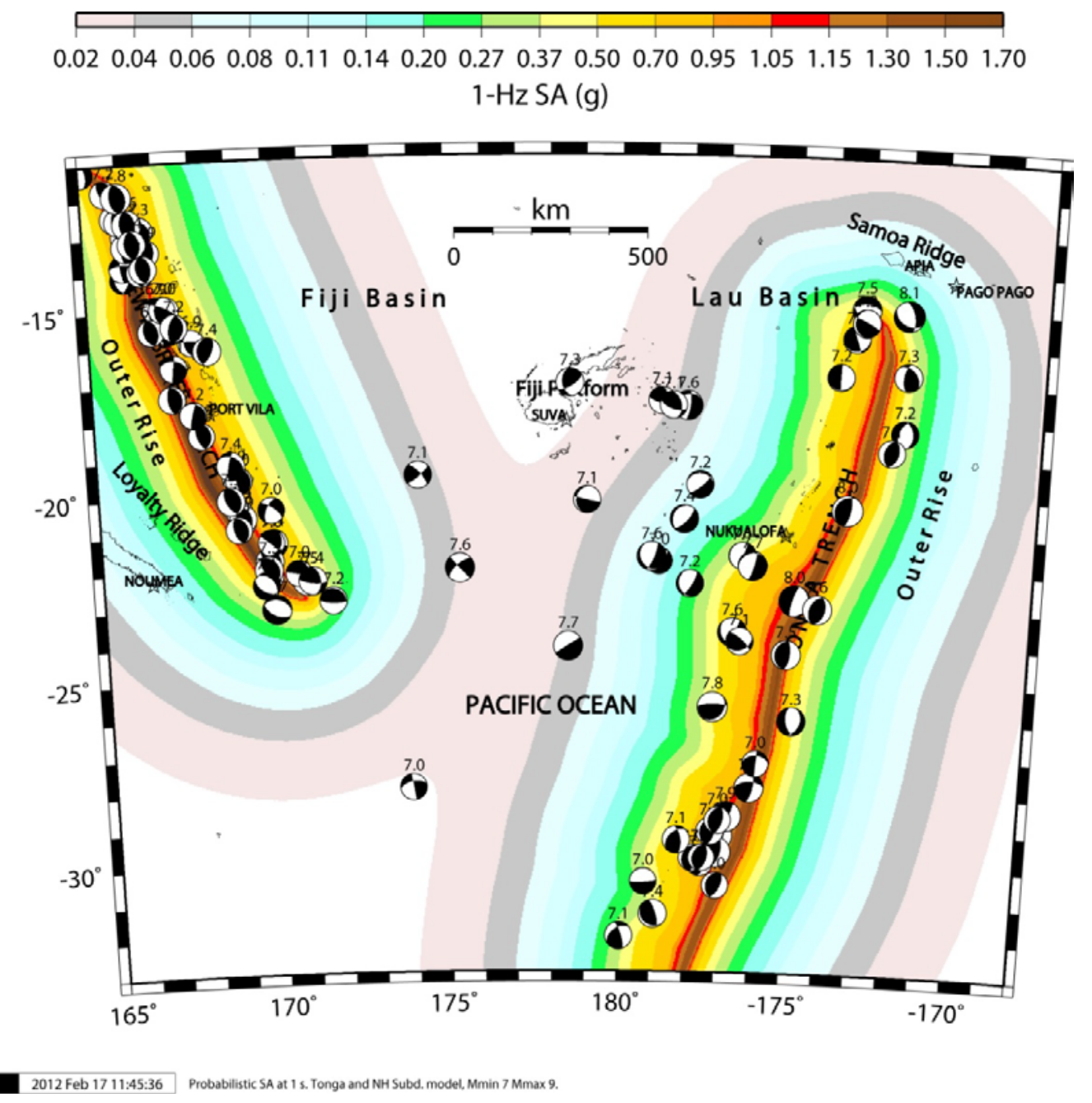

Figure 26. Seismic hazard contributed by the Tonga and New Hebrides subduction zones 1 Hertz spectral acceleration for 2 percent probability of exceedance in 50 years on a uniform firm rock site condition. Focal mechanisms derived for $M \geq 7$. Many of mechanisms correspond to non-subduction processes or intraslab processes. (Hz, hertz; SA, spectral acceleration; g, acceleration of gravity; km, kilometers ) 


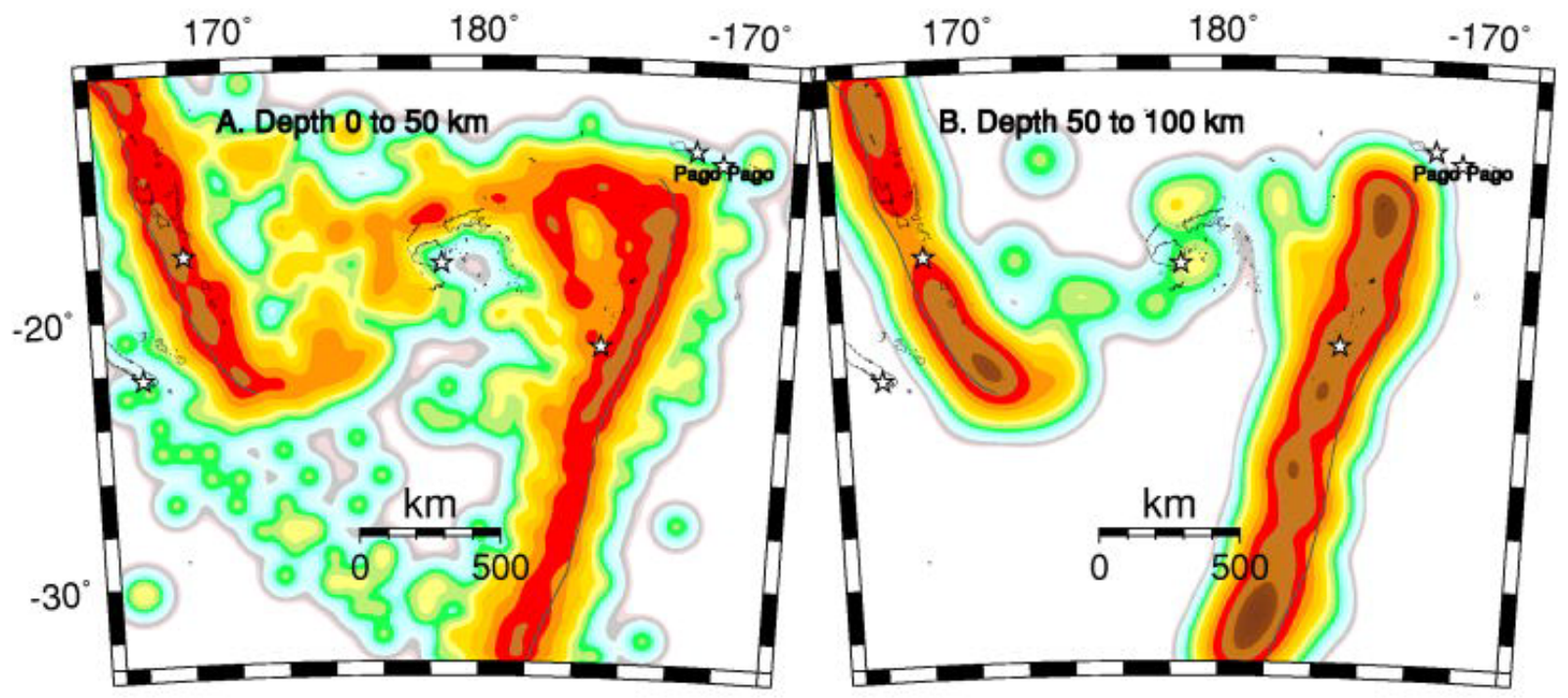

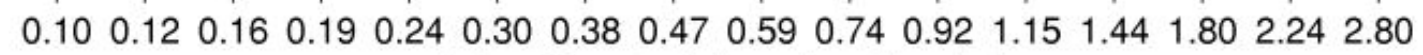

0.2-s Spectral Acceleration (g)

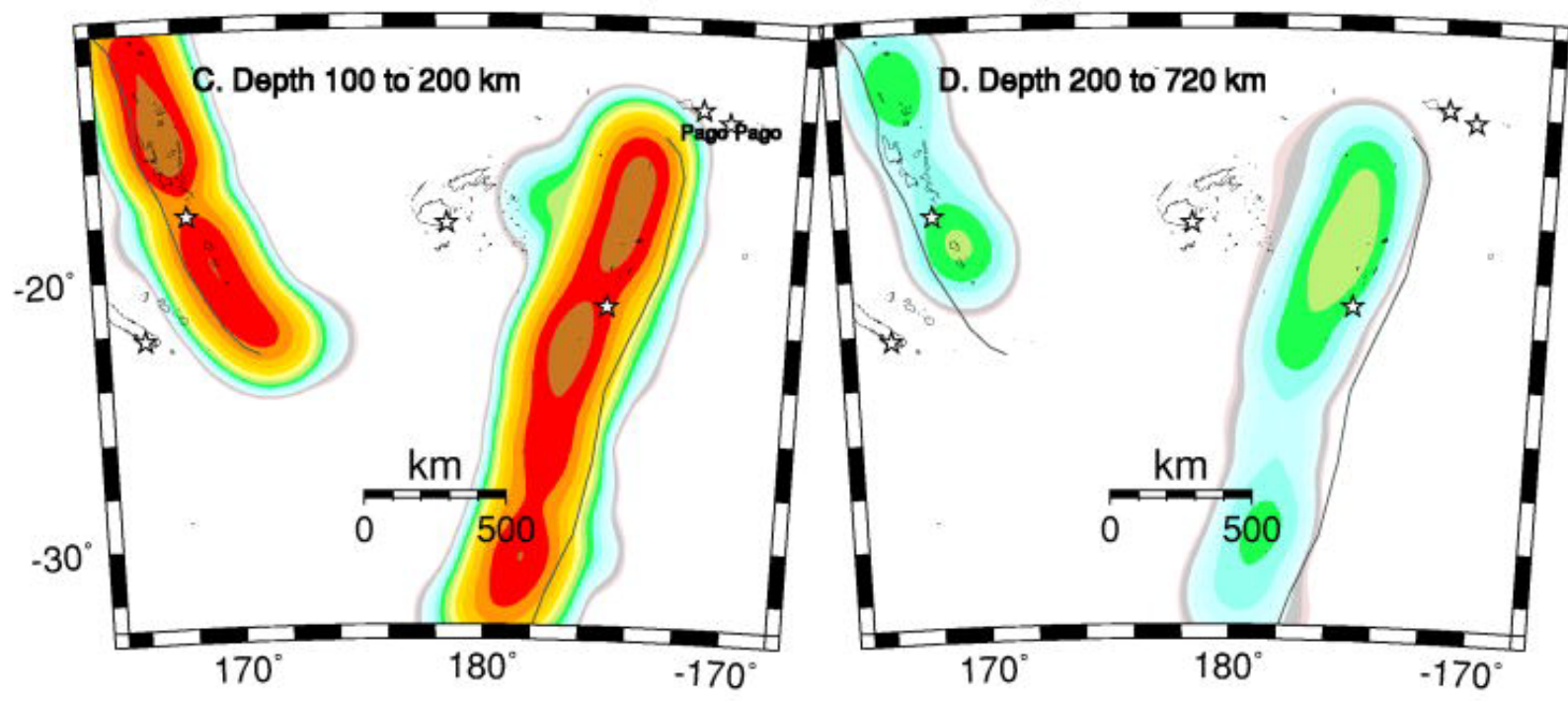

Figure 27. Background hazard maps for 5 Hertz Spectral Acceleration 2 percent probability of exceedance in 50 years on firm rock site condition for earthquake sources with depths $A, 0-50$ kilometers $(\mathrm{km}) ; B, 50-100 \mathrm{~km}$; C, $100-200 \mathrm{~km} ; D, 200-750 \mathrm{~km}$. 

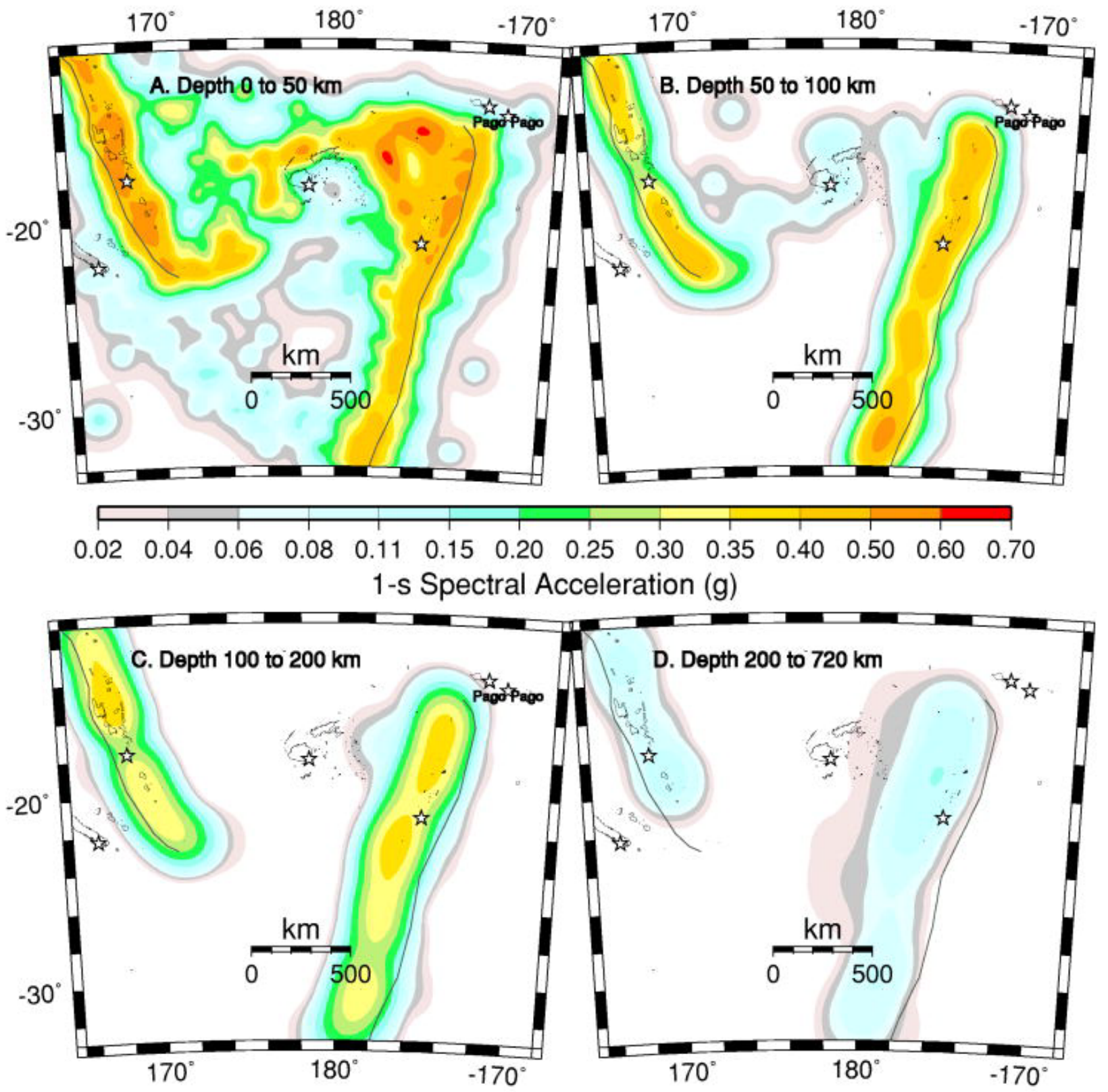

Figure 28. Background hazard maps for 1 Hertz Spectral Acceleration 2 percent probability of exceedance in 50 years on firm rock site condition for earthquake sources with depths $A, 0-50$ kilometers $(\mathrm{km}) ; B, 50-100 \mathrm{~km}$; C, 100-200 km; and D, 200-750 km. 
Seismic-Hazard Maps For American Samoa

Horizontal Spectral Response Acceleration for 1.0-Second Period

(5\% of Critical Damping)

With $10 \%$ Probability of Exceedance in 50 Years
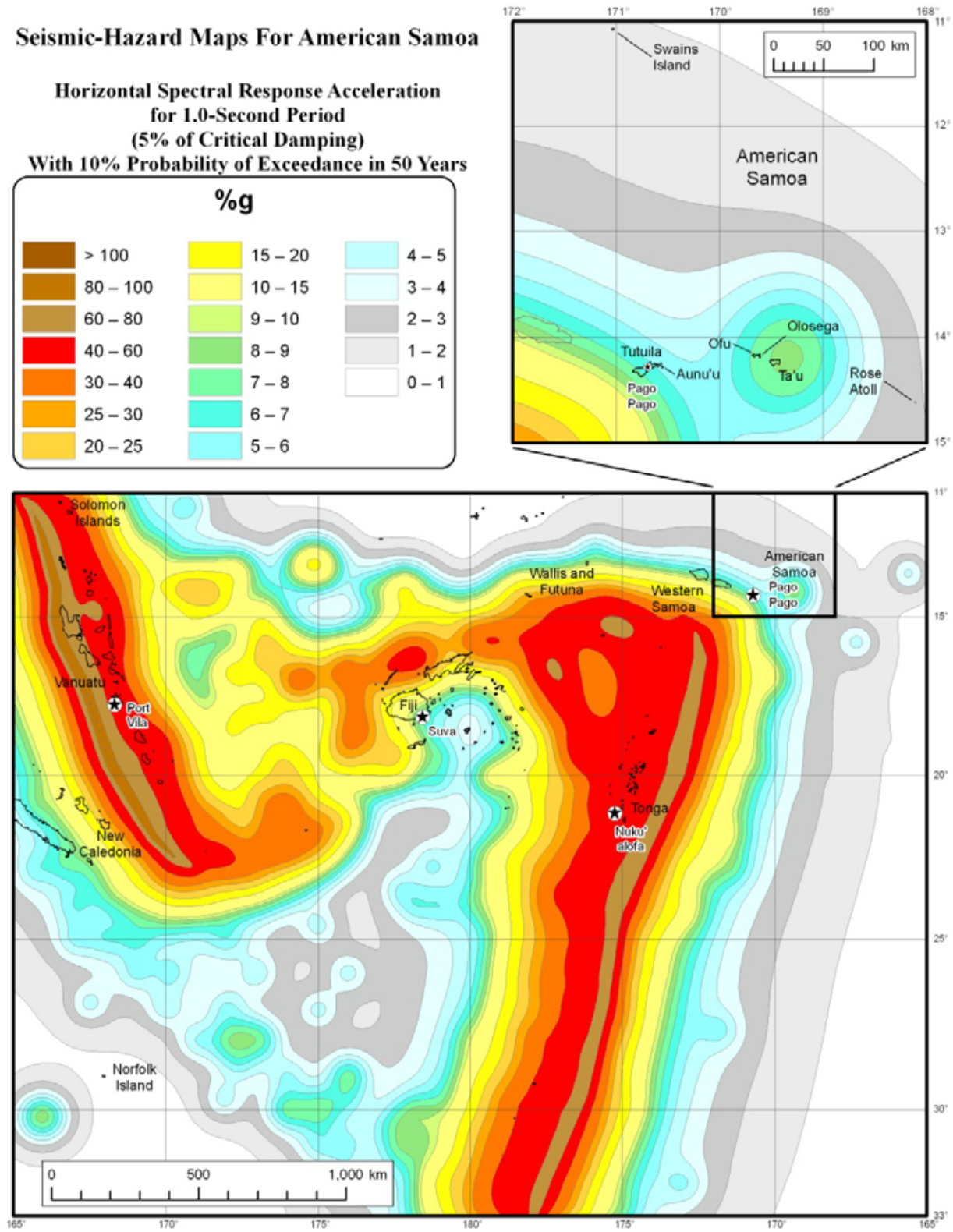

Figure 29. Hazard map with all sources for 1 -second Spectral Acceleration 10 percent probability of exceedance in 50 years on firm rock site condition. (\%g, percent of the acceleration of gravity; $\mathrm{km}$, kilometer) 


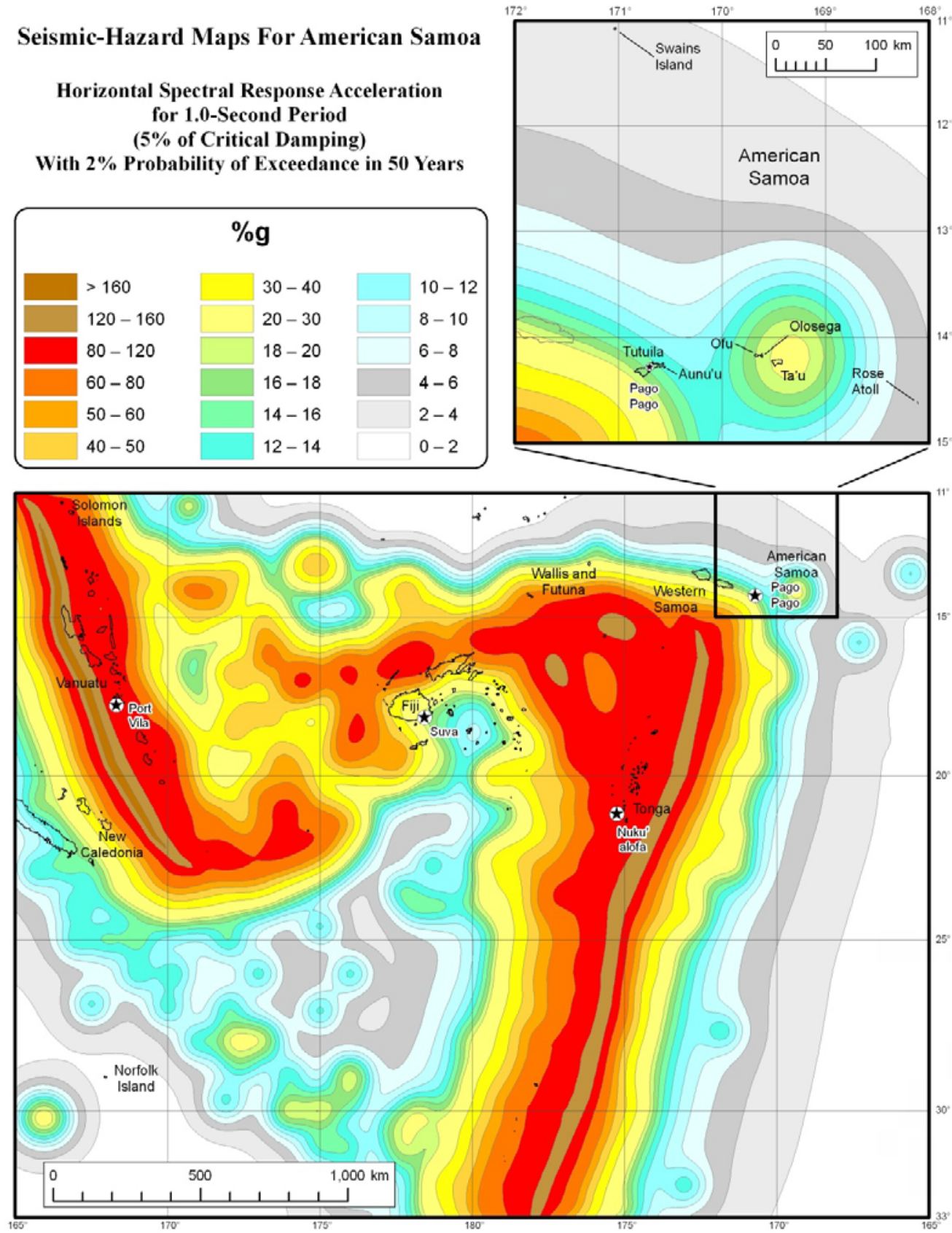

Figure 30. Hazard map with all sources for 1-Hertz Spectral Acceleration 2-percent probability of exceedance in 50 years on firm rock site condition. (\%g, percent of the acceleration of gravity; km, kilometer) 


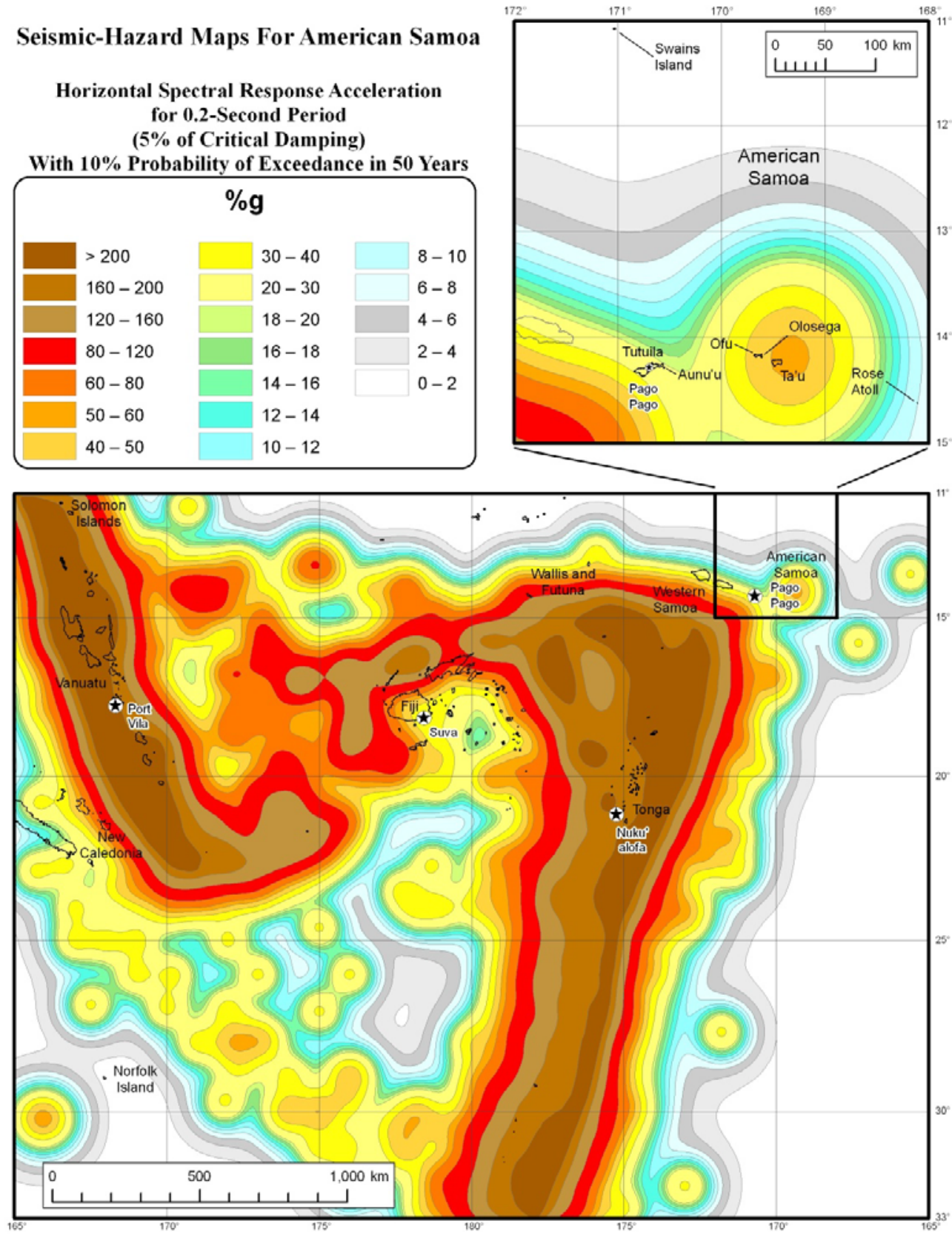

Figure 31. Hazard map with all sources for 5-Hertz Spectral Acceleration 10 percent probability of exceedance in 50 years on firm rock site condition. (\%g, percent of the acceleration of gravity; km, kilometer) 


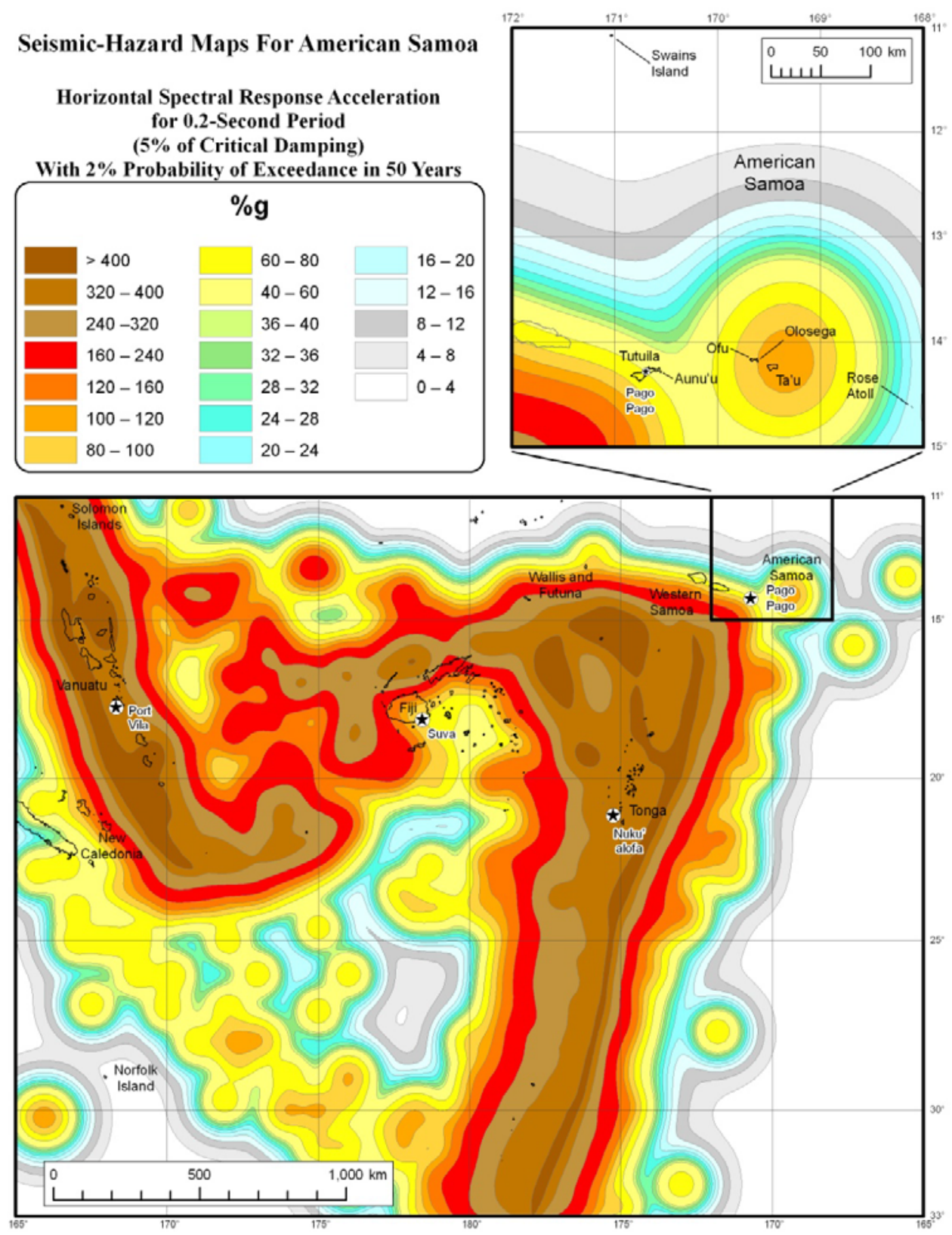

Figure 32. Hazard map with all sources for 5-Hertz Spectral Acceleration 2 percent probability of exceedance in 50 years on firm rock site condition. (\%g, percent of the acceleration of gravity; $\mathrm{km}$, kilometer) 

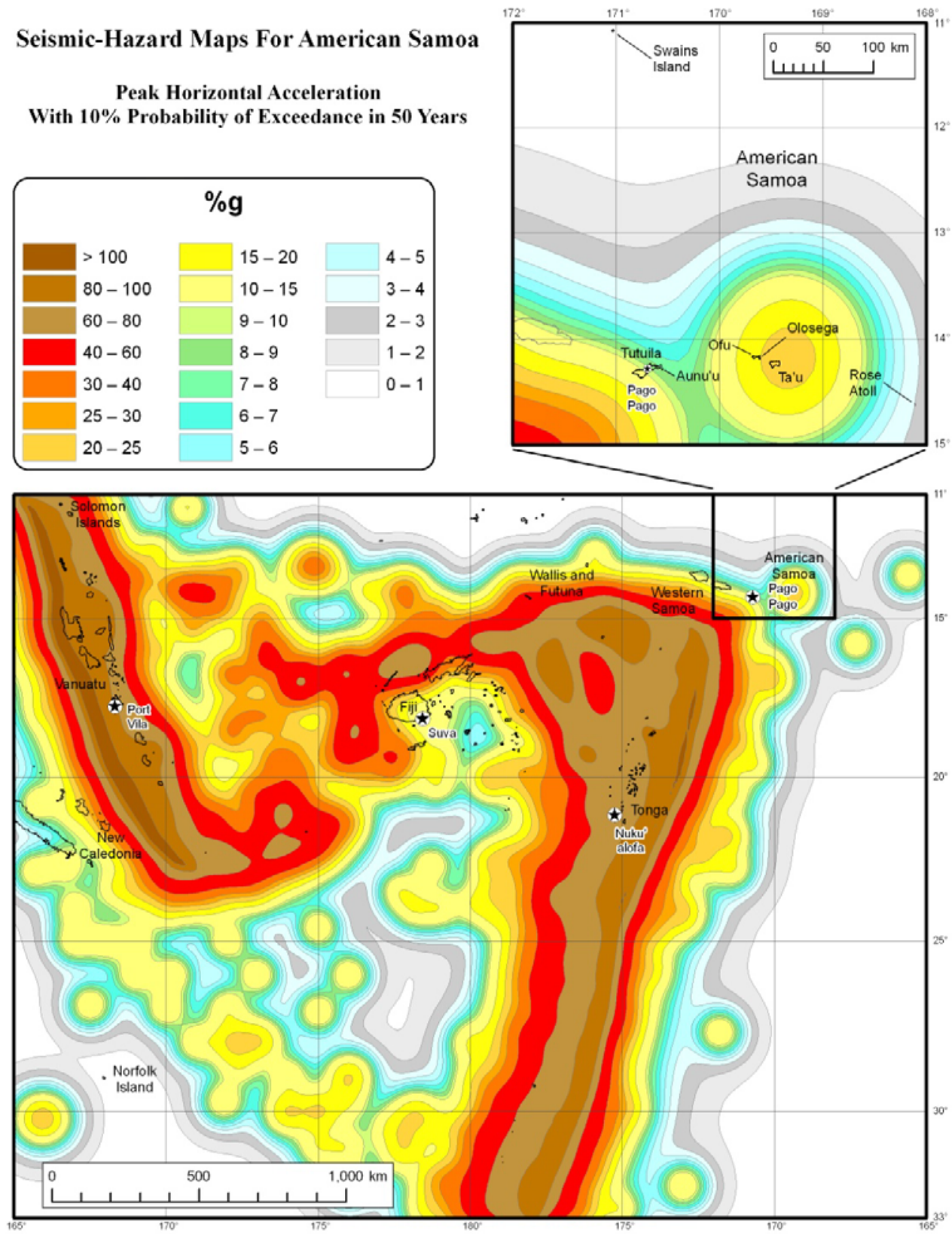

Figure 33. Hazard map with all sources for Peak Horizontal Ground Acceleration with a 10 percent probability of exceedance in 50 years on firm rock site condition. (\%g, percent of the acceleration of gravity; $\mathrm{km}$, kilometer) 


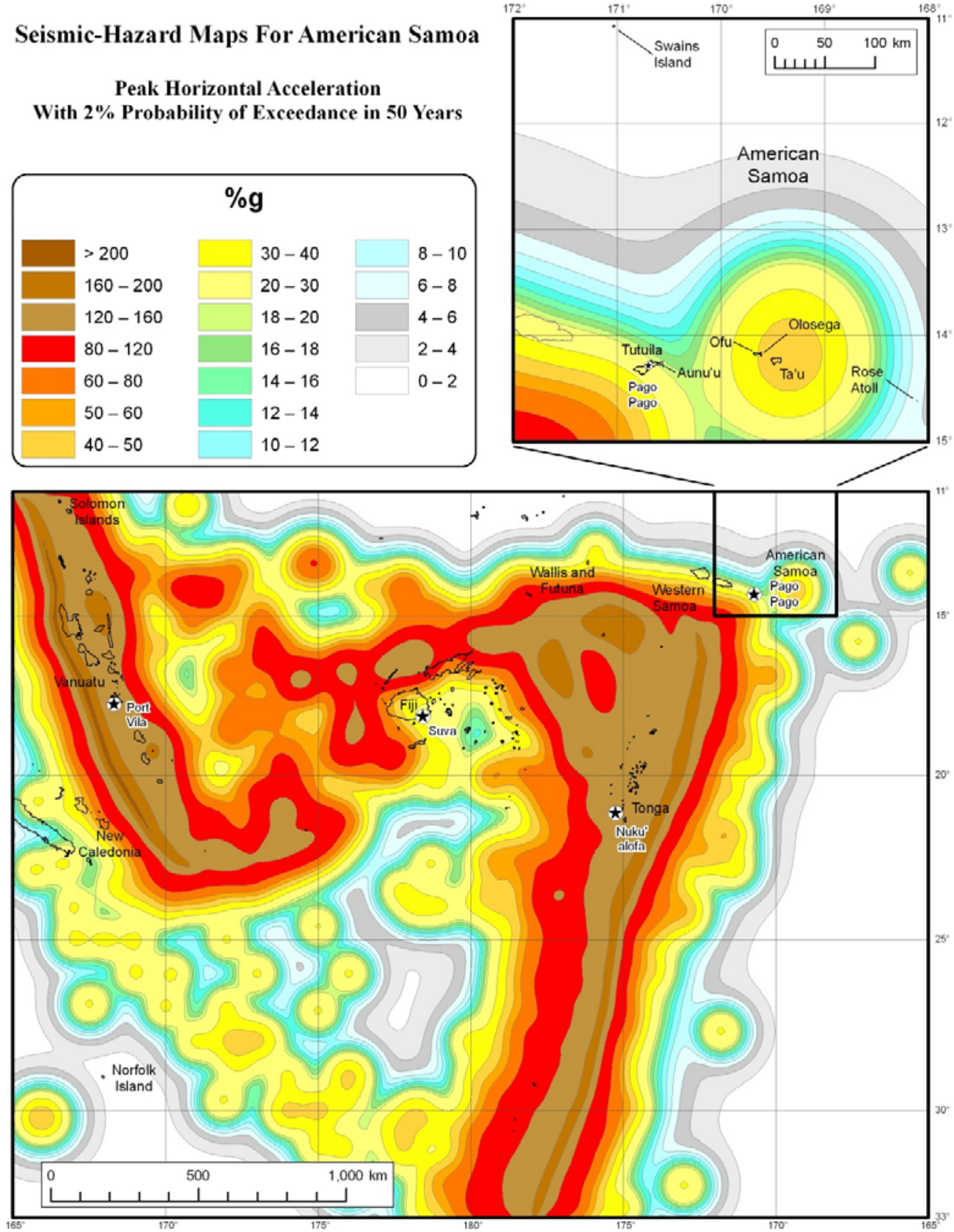

Figure 34. Hazard map with all sources for Peak Horizontal Ground Acceleration with a 2 percent probability of exceedance in 50 years on firm rock site condition. (\%g, percent of the acceleration of gravity; $\mathrm{km}$, kilometer) 
Pago Pago

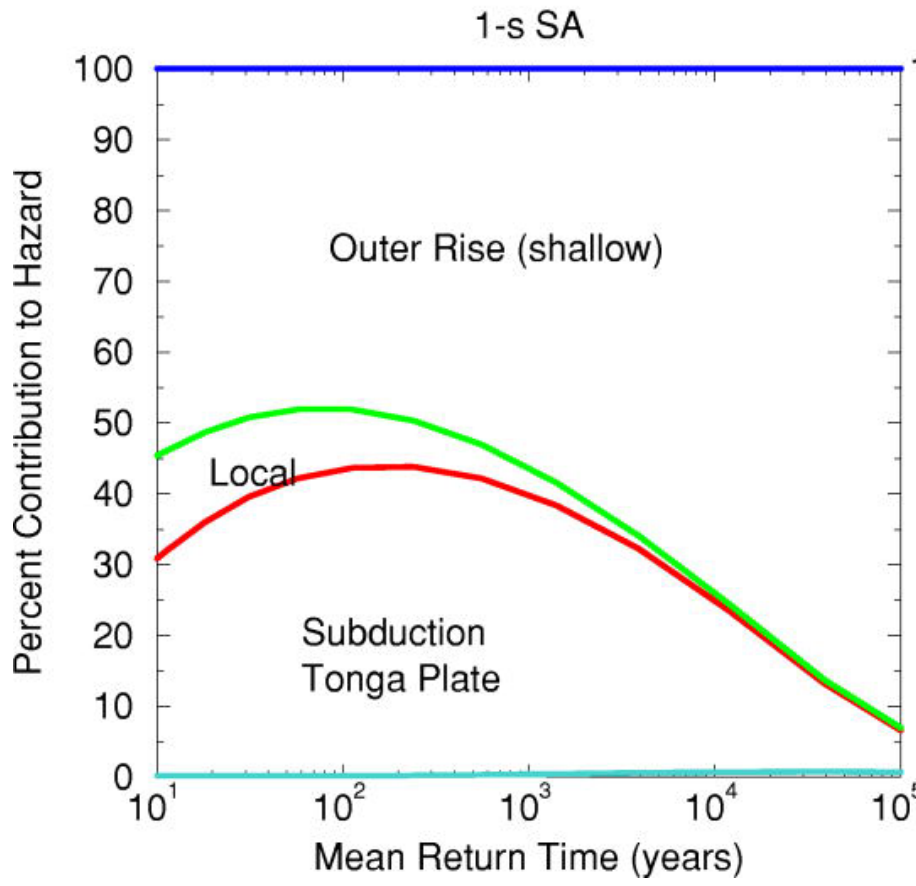

Pago Pago

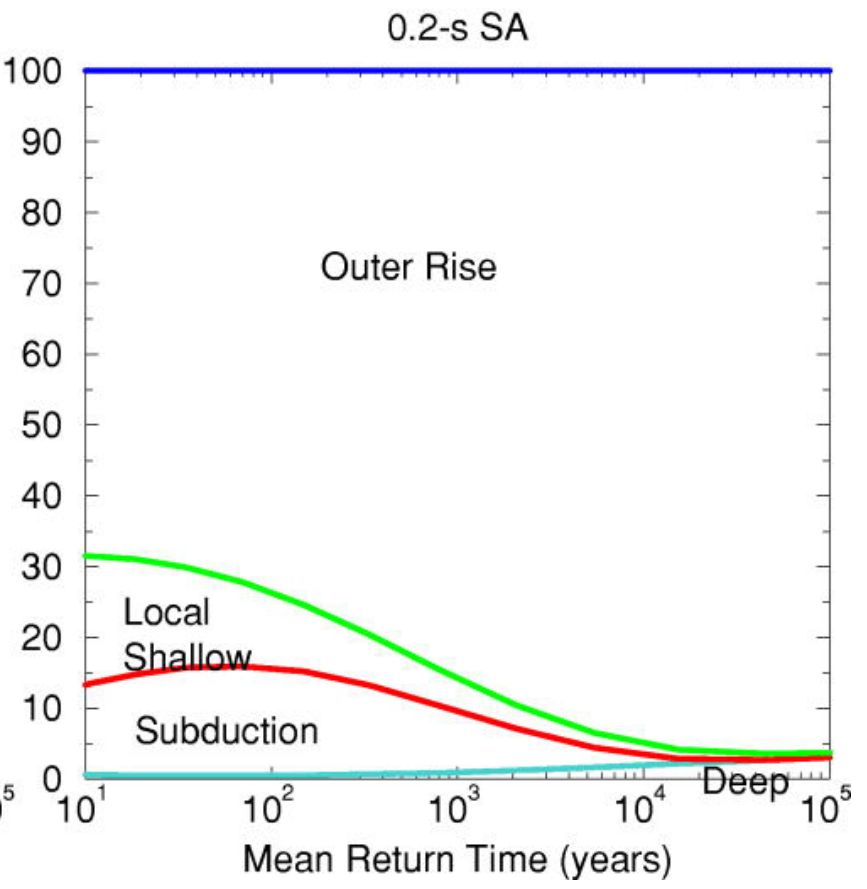

$B$ Pago_Pago $170.710^{\circ} \mathrm{W},-14.300^{\circ} \mathrm{N}$.

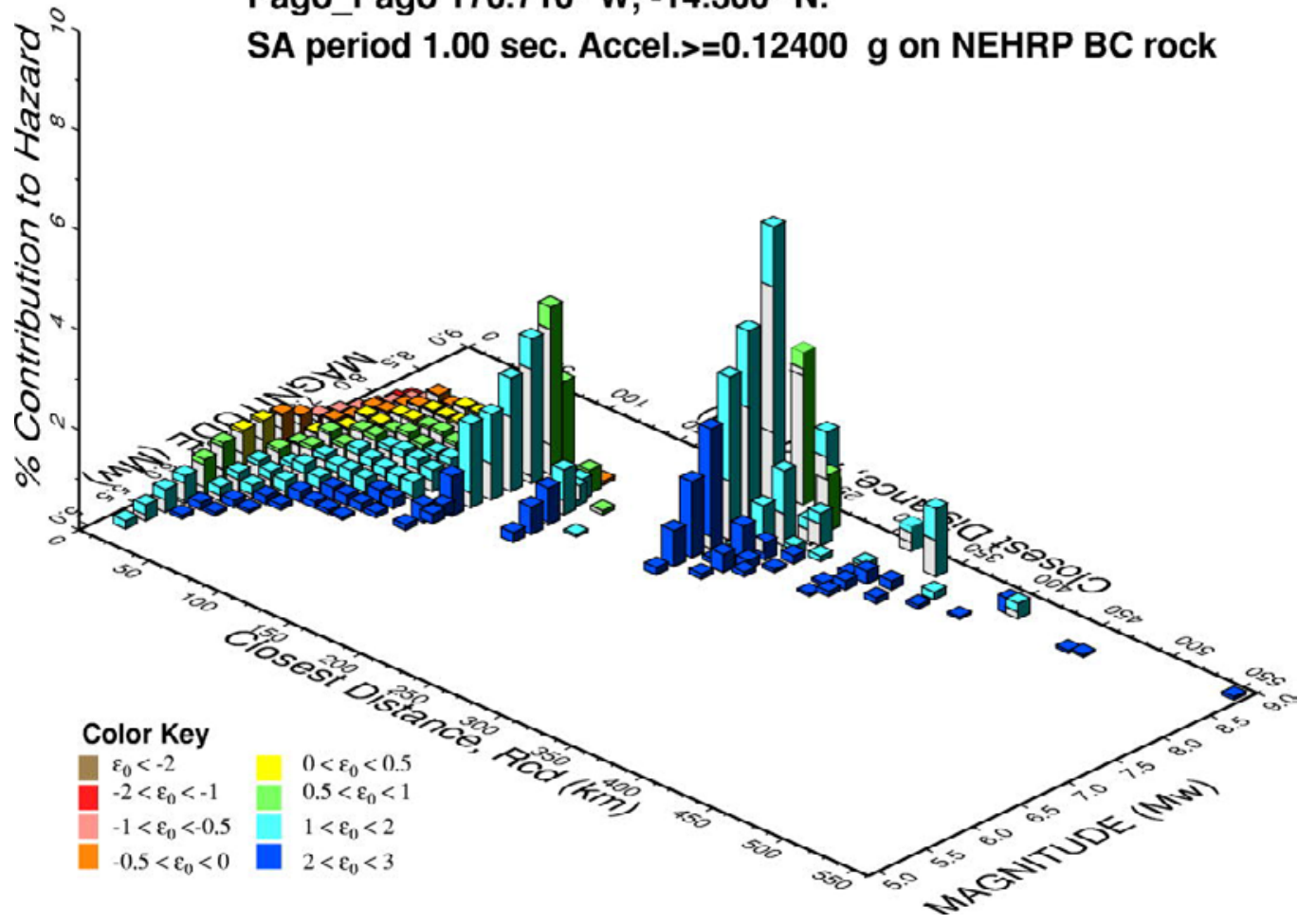



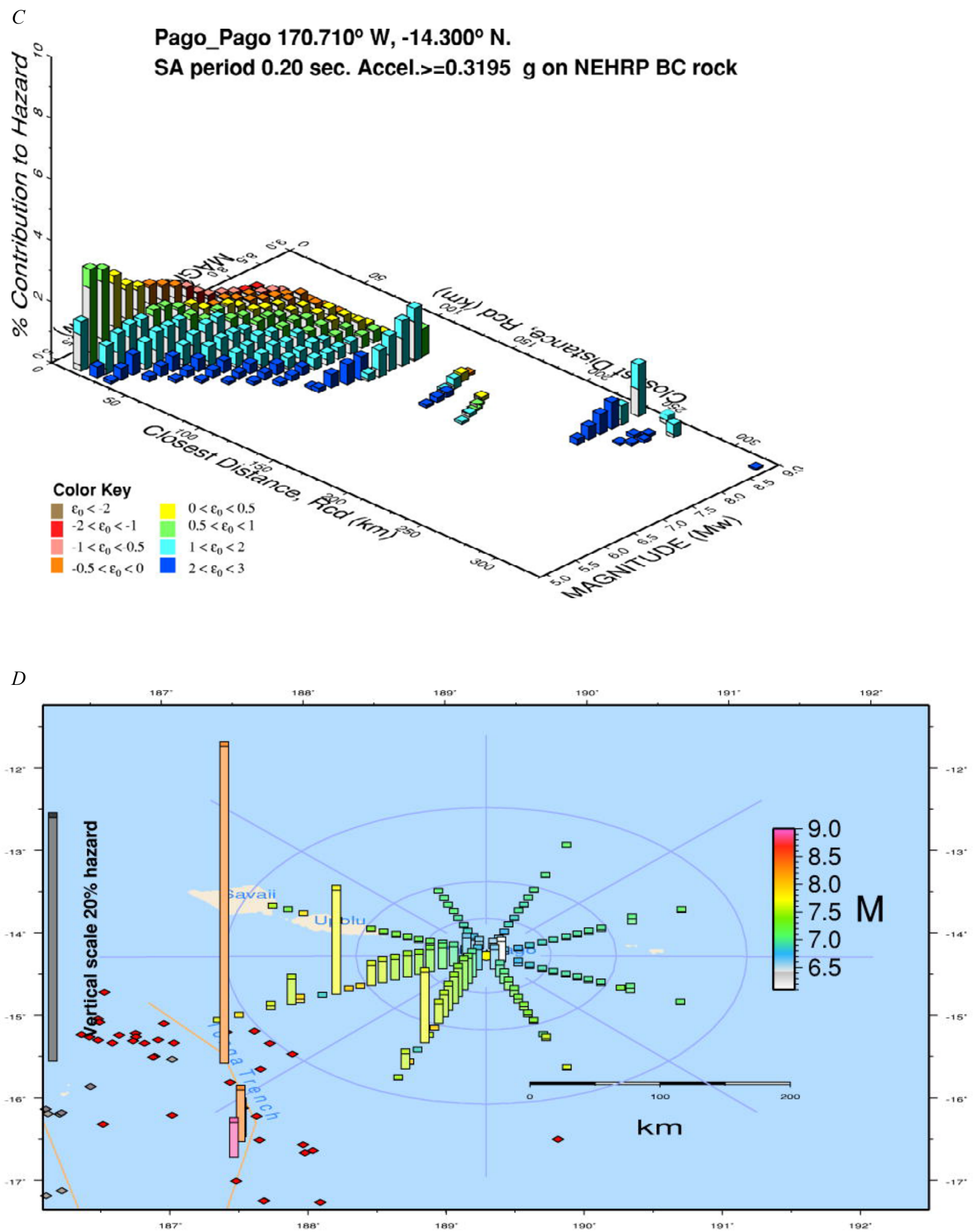


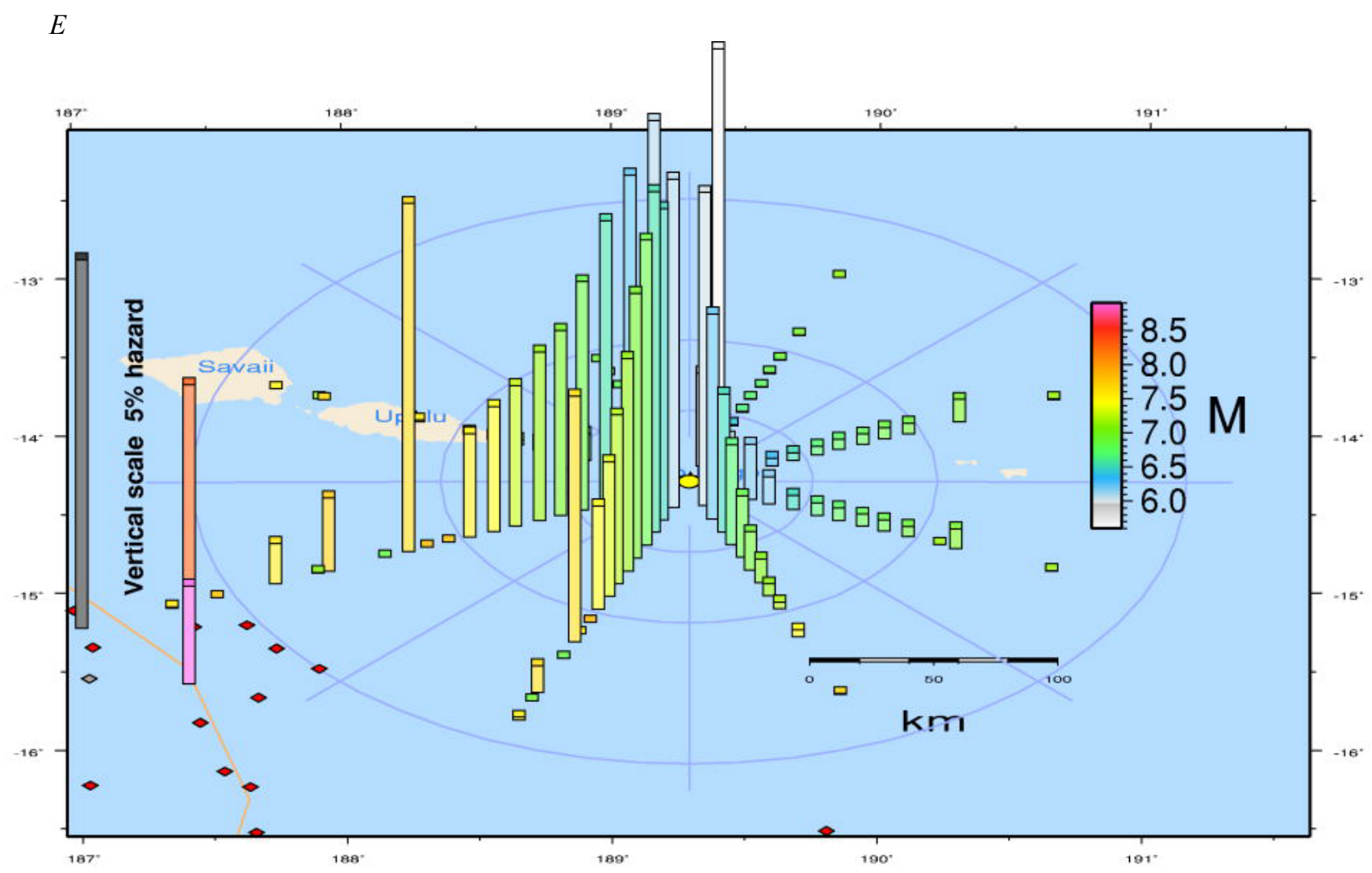

Figure 35. Deaggregation plots of a site at Pago Pago, American Samoa for 1 second (sec) (1 Hertz (Hz)) and $0.2 \mathrm{~s}(5 \mathrm{~Hz})$ spectral accelerations. $A$, Plot of percent contribution to hazard and mean return time in years, showing the relative contribution to the overall hazard for different return times. The area between the curves represents the contribution of that source to the overall hazard for $1 \mathrm{~s}$ and $0.2 \mathrm{~s} \mathrm{spectral} \mathrm{accelerations} \mathrm{at} \mathrm{Pago} \mathrm{Pago.} \mathrm{B,} \mathrm{Plot} 1 \mathrm{~s}$ $(1 \mathrm{~Hz})$ showing the magnitudes, distances, and epsilons for 2 percent probability of exceedance in 50 years that contribute most to the hazard. $C$, Plot $0.2 \mathrm{~s}(5 \mathrm{~Hz})$ showing the magnitudes, distances, and epsilons for 2 percent probability of exceedance in 50 years that contribute most to the hazard. $D$, Geographic deaggregations that show the contributions of earthquake sources on a map to the $1 \mathrm{~s}(1 \mathrm{~Hz})$ overall hazard. E, Geographic deaggregations that show the contributions of earthquake sources on a map to the $0.2 \mathrm{~s}(5 \mathrm{~Hz})$ overall hazard. (km, kilometers; $\mathrm{SA}$, Spectral Acceleration; sec, seconds; g, acceleration of gravity; Mw or M, Moment magnitude;) 

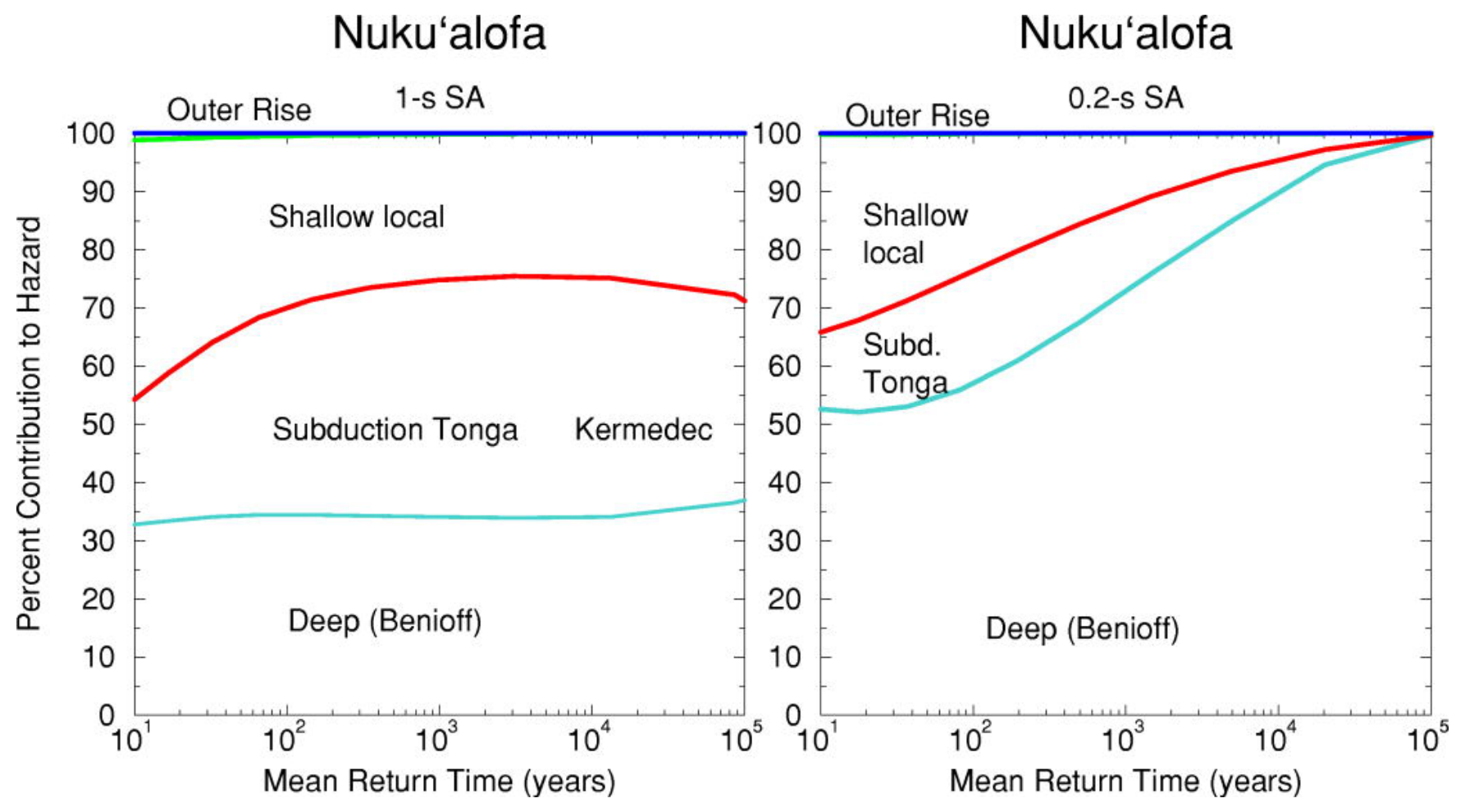

B

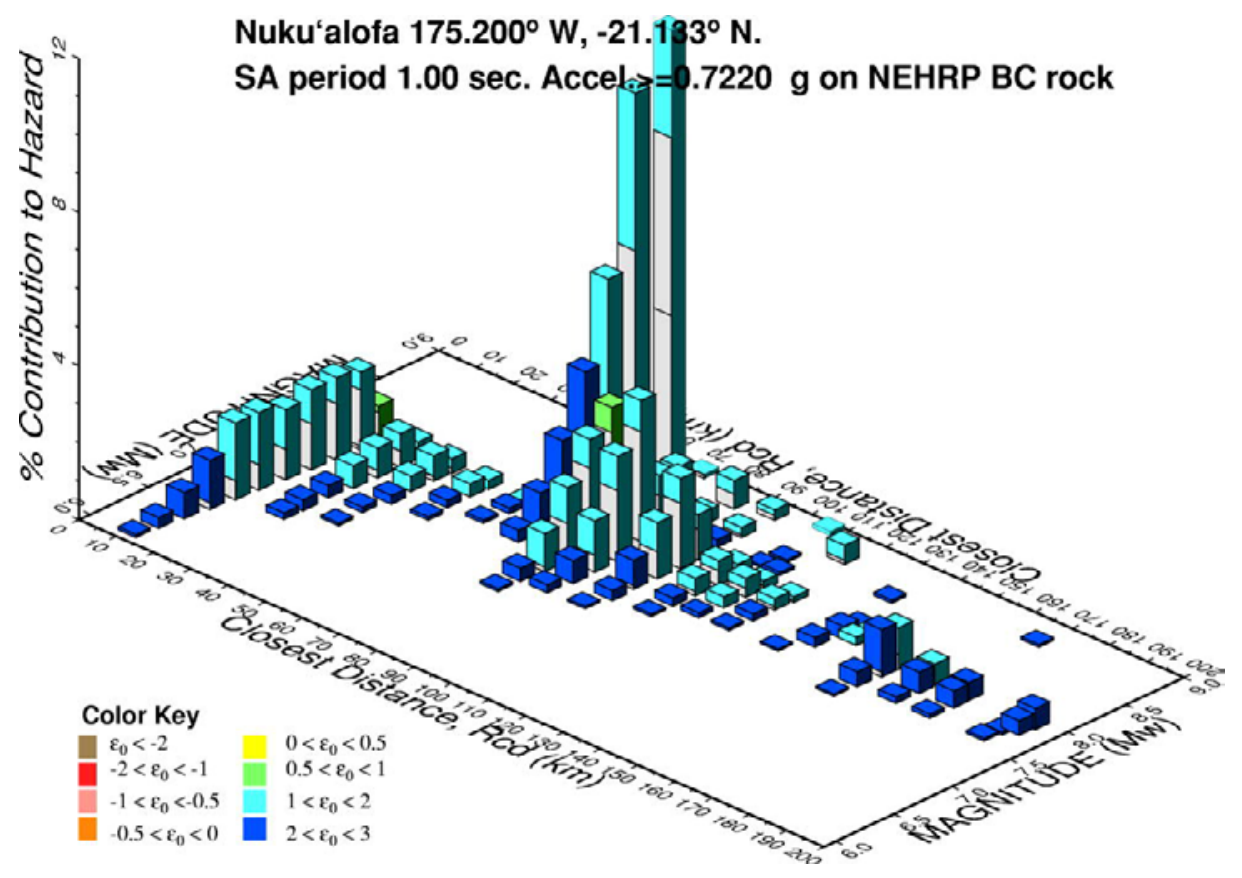



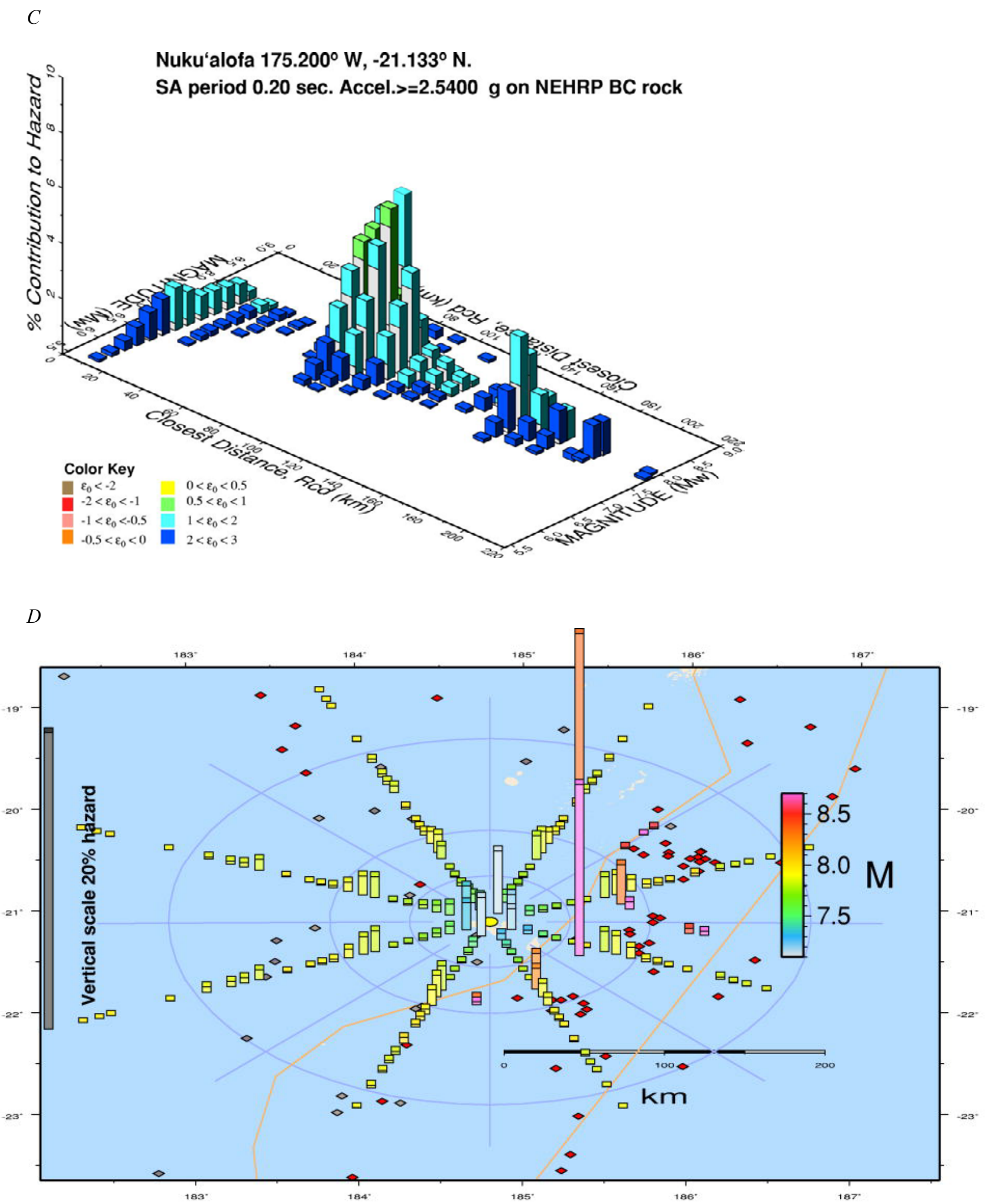


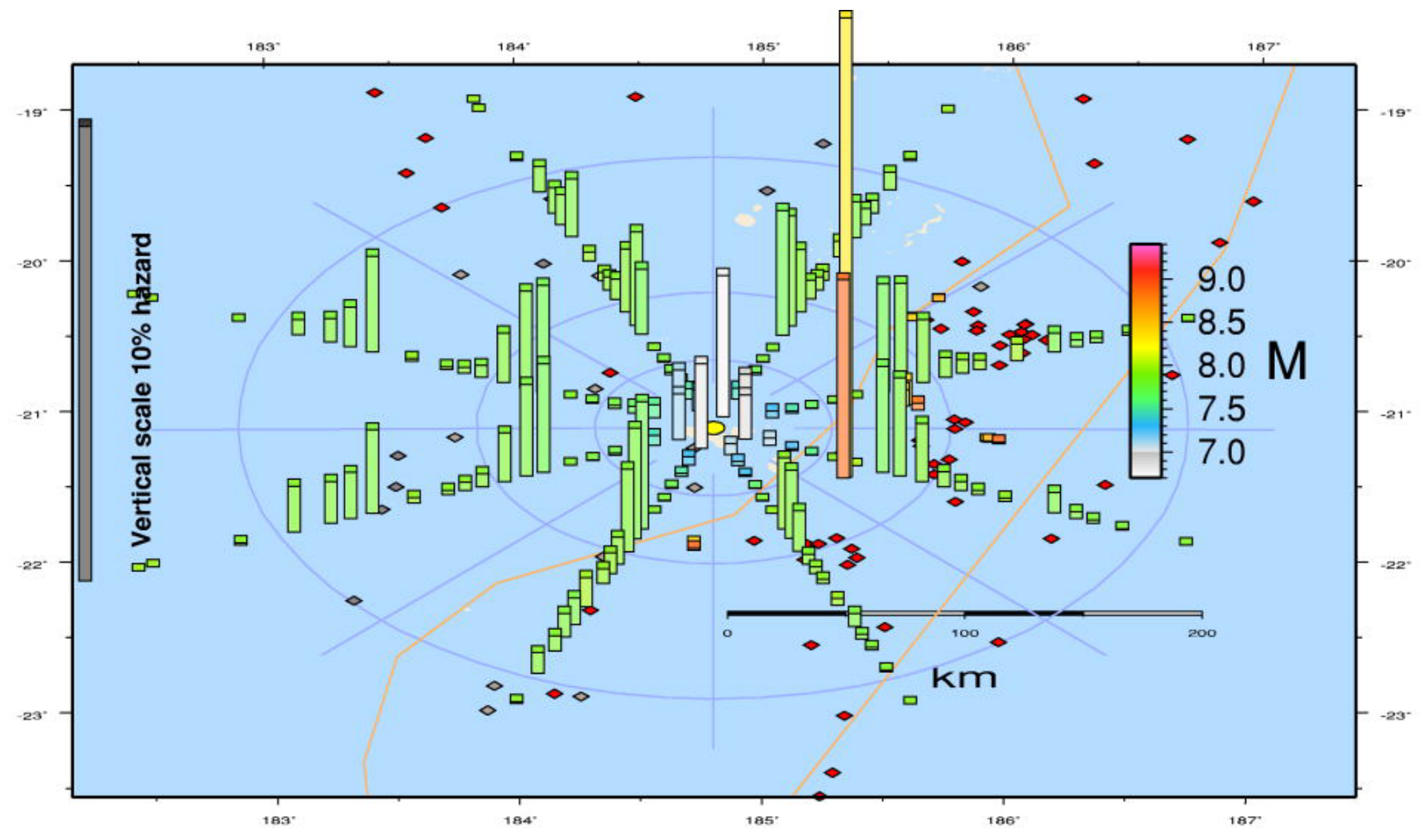

Figure 36. Deaggregation plots of a site at Nuku'alofa, Tonga for 1 second $(\mathrm{sec})(1 \mathrm{Hertz}(\mathrm{Hz}))$ and $0.2 \mathrm{~s}(5 \mathrm{~Hz})$ spectral accelerations. $A$, Plot of percent contribution to hazard and mean return time in years showing the relative contribution to the overall hazard for different return times. The area between the curves represents the contribution of that source to the overall hazard for 1 and $0.2 \mathrm{~s}$ spectral accelerations at Pago Pago. B, Plot 1 second $(1 \mathrm{~Hz})$ showing the magnitudes, distances, and epsilons for 2 percent probability of exceedance in 50 years that contribute most to the hazard. $C$, Plot $0.2 \mathrm{~s}(5 \mathrm{~Hz})$ showing the magnitudes, distances, and epsilons for 2-percent probability of exceedance in 50 years that contribute most to the hazard. $D$, Geographic deaggregations that show the contributions of earthquake sources on a map to the 1-s $(1 \mathrm{~Hz})$ overall hazard. E, Geographic deaggregations that show the contributions of earthquake sources on a map to the $0.2-\mathrm{s}(5 \mathrm{~Hz})$ overall hazard. (km, kilometers; $\mathrm{SA}$, spectral acceleration; sec, seconds; $\mathrm{g}$, define here; $\mathrm{M}$ and $\mathrm{Mw}$, both represent moment magnitude) 
Suva

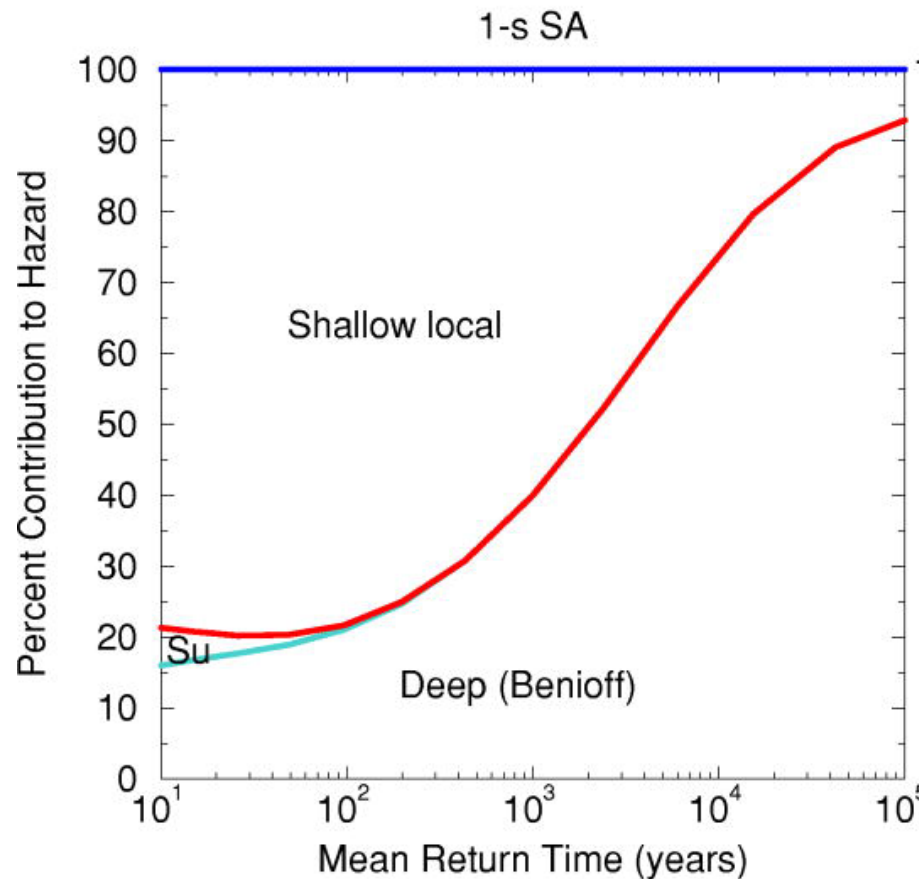

Suva

0.2-s SA

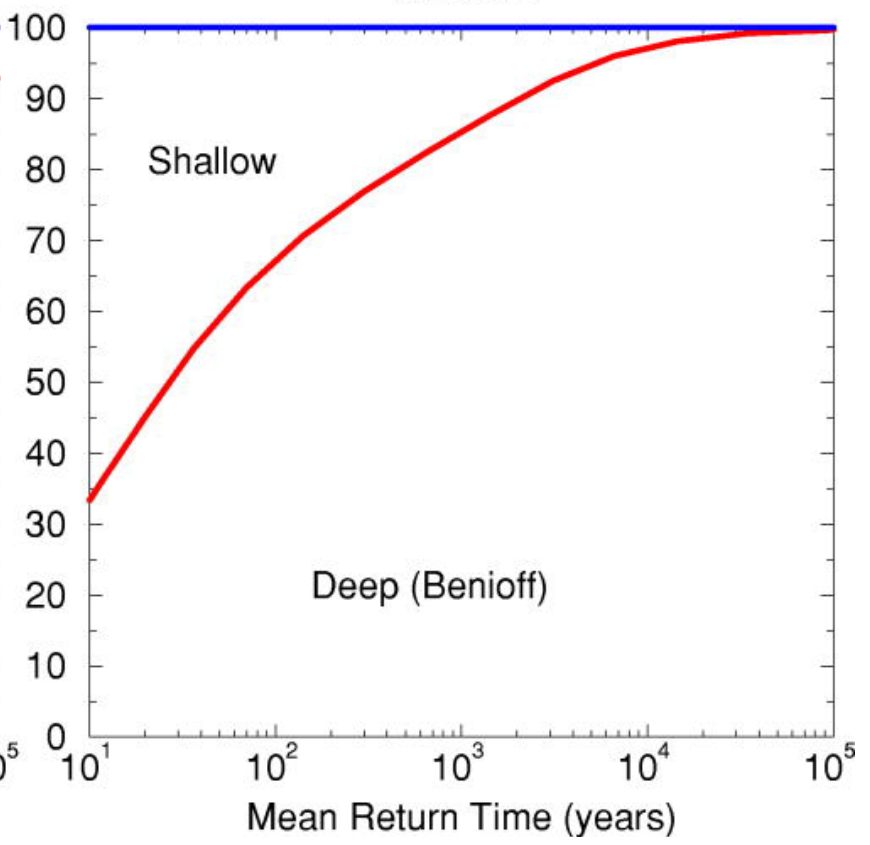

B

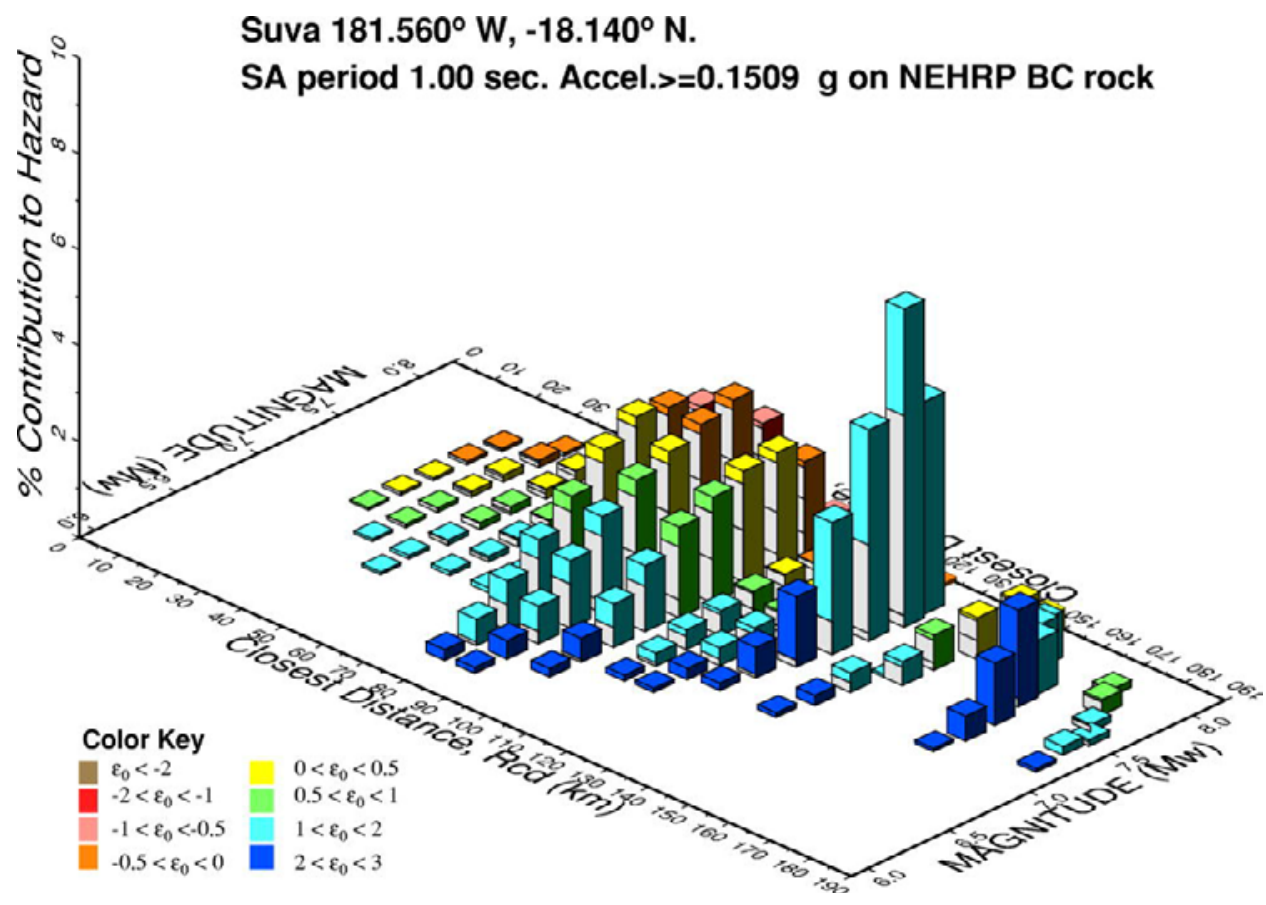




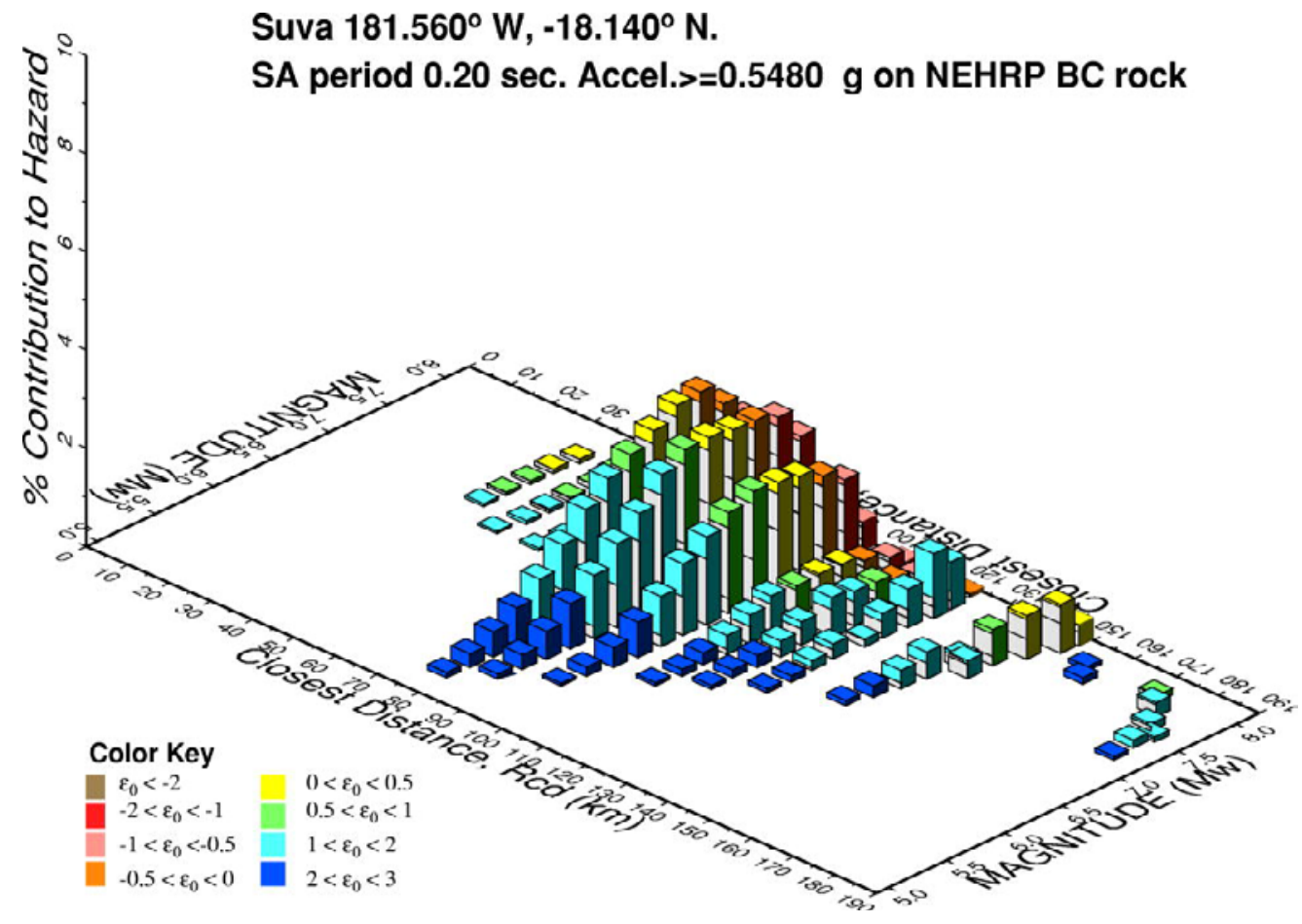

$D$

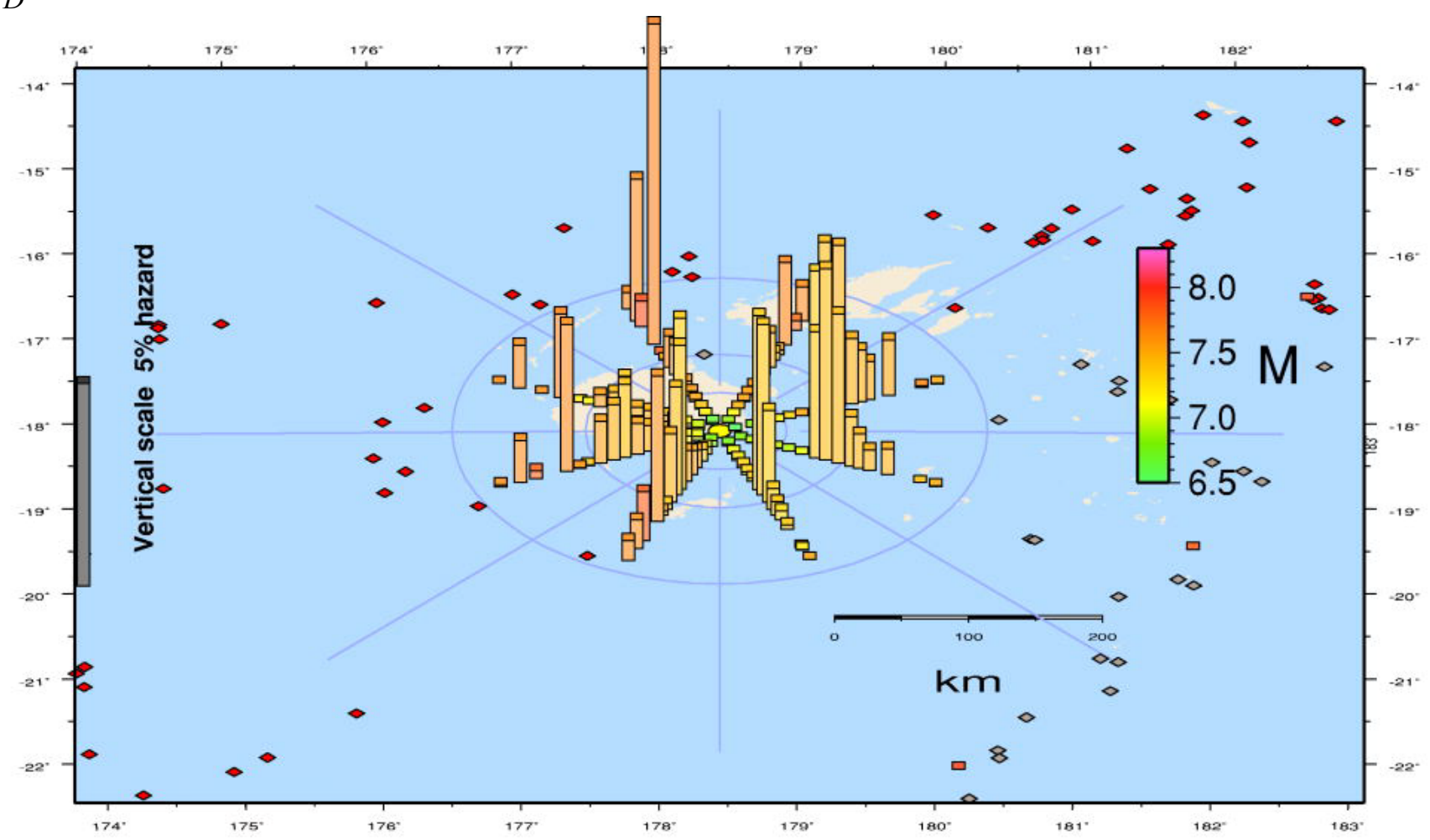




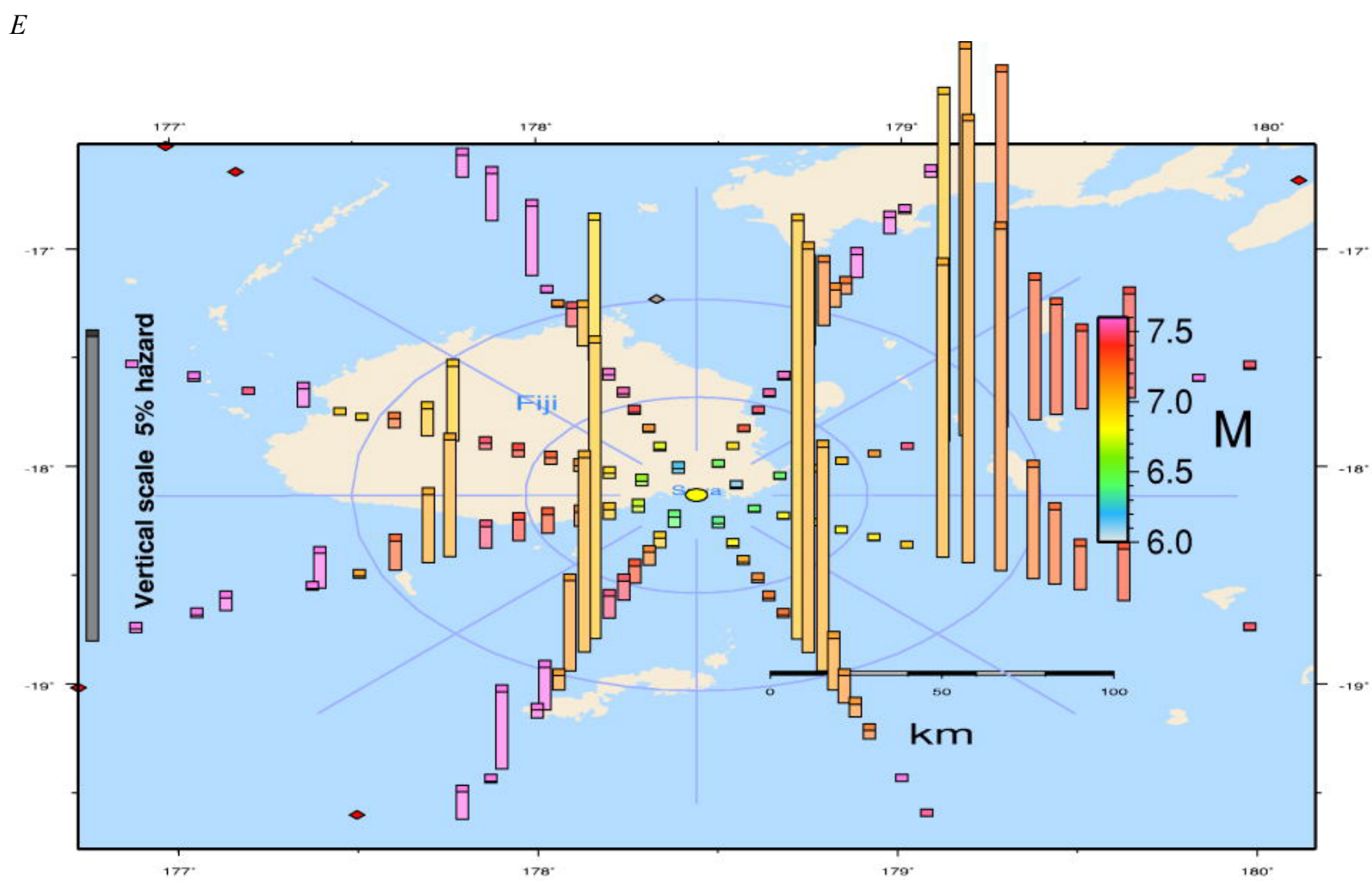

Figure 37. Deaggregation plots of a site at Suva, Fiji for $1 \mathrm{~second}(\mathrm{sec})(1 \mathrm{Hertz}(\mathrm{Hz}))$ and $0.2 \mathrm{~s}(5 \mathrm{~Hz})$ spectral accelerations. $A$, Plot of percent contribution to hazard and mean return time in years showing the relative contribution to the overall hazard for different return times. The area between the curves represents the contribution of that source to the overall hazard for 1 and $0.2 \mathrm{~s}$ spectral accelerations at Pago Pago. B, Plot 1 second $(1 \mathrm{~Hz})$ showing the magnitudes, distances, and epsilons for 2 percent probability of exceedance in 50 years that contribute most to the hazard. $C$, Plot $0.2 \mathrm{~s}(5 \mathrm{~Hz})$ showing the magnitudes, distances, and epsilons for 2 percent probability of exceedance in 50 years that contribute most to the hazard. $D$, Geographic deaggregations that show the contributions of earthquake sources on a map to the1-s $(1 \mathrm{~Hz})$ overall hazard. $E$, Geographic deaggregations that show the contributions of earthquake sources on a map to the $0.2-\mathrm{s}(5 \mathrm{~Hz})$ overall hazard. (km, kilometers; SA, spectral acceleration; sec, seconds; g, acceleration of gravity; Mw, and M, represent moment magnitude) 


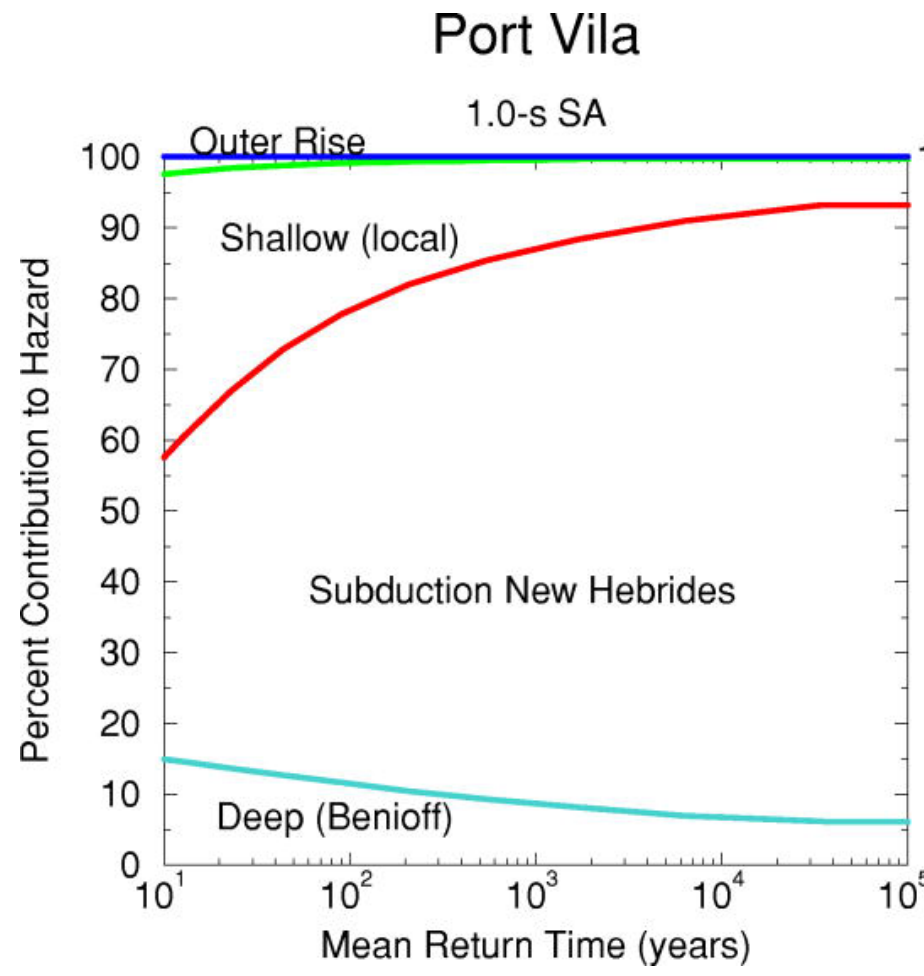

Port Vila

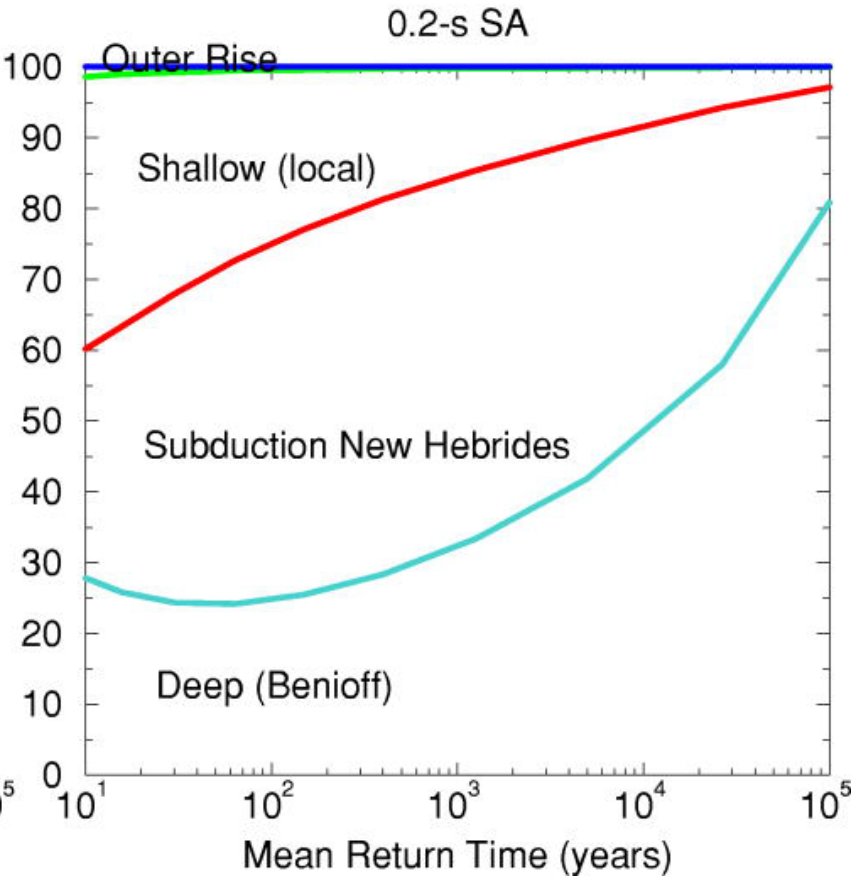

B

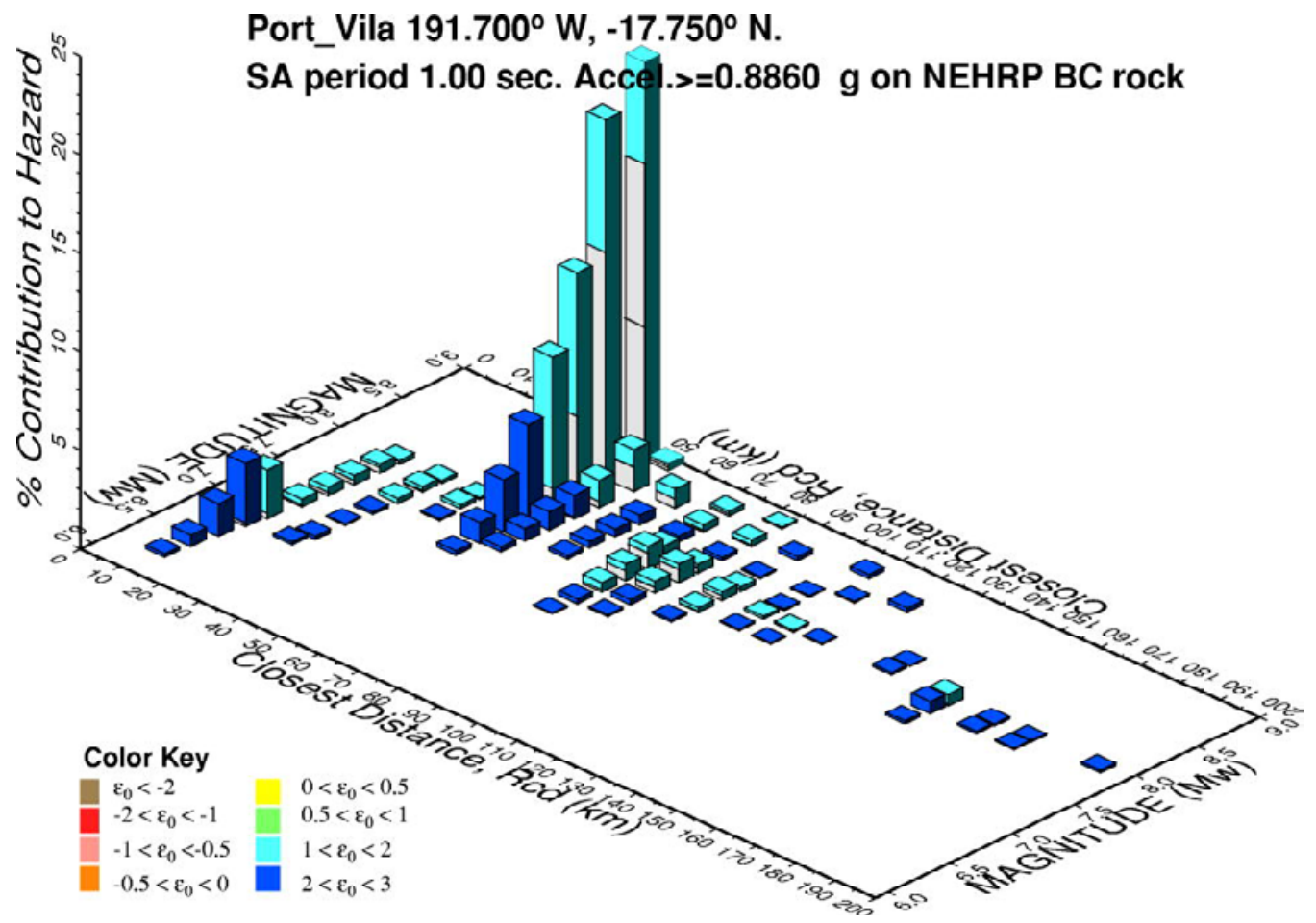



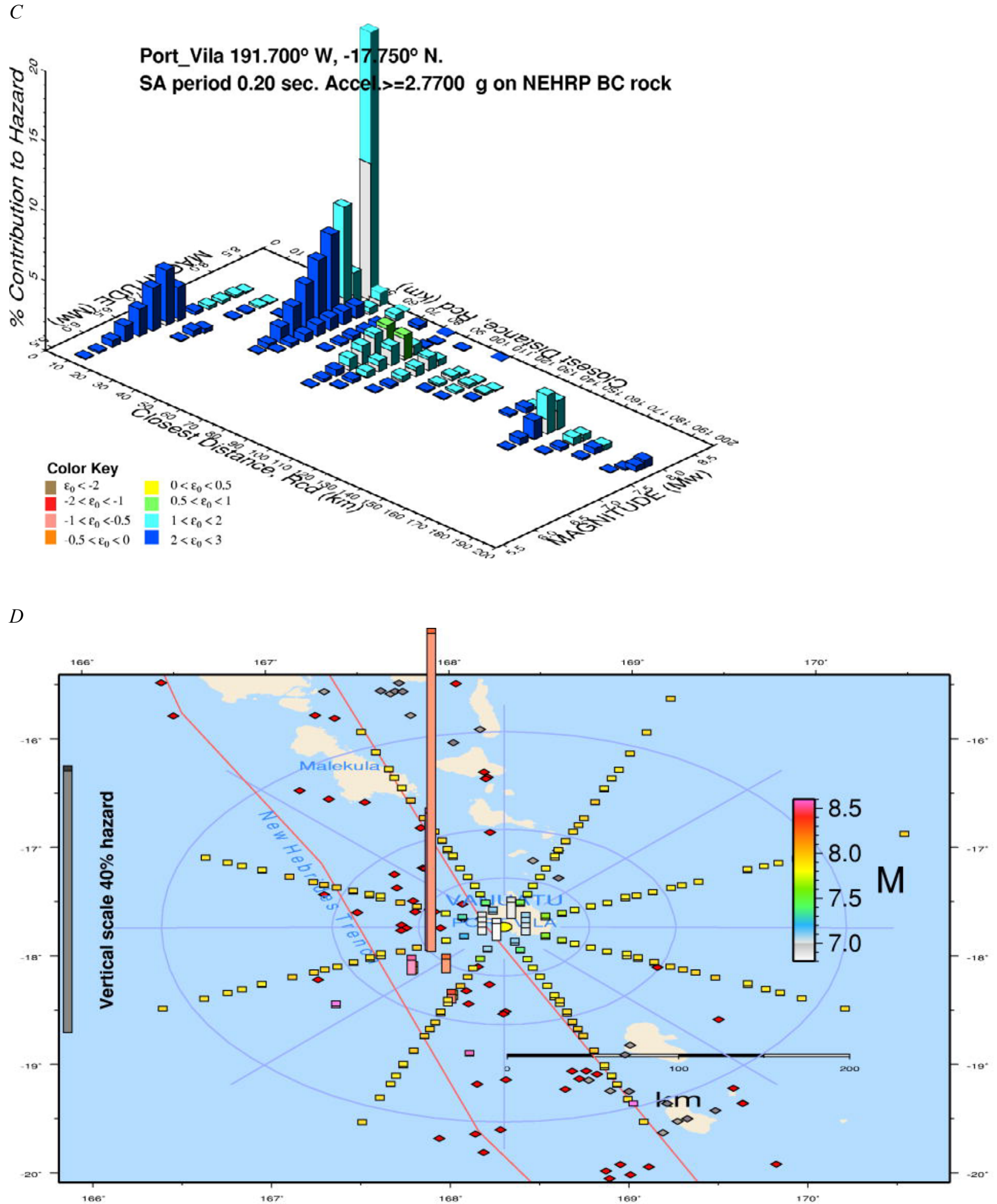


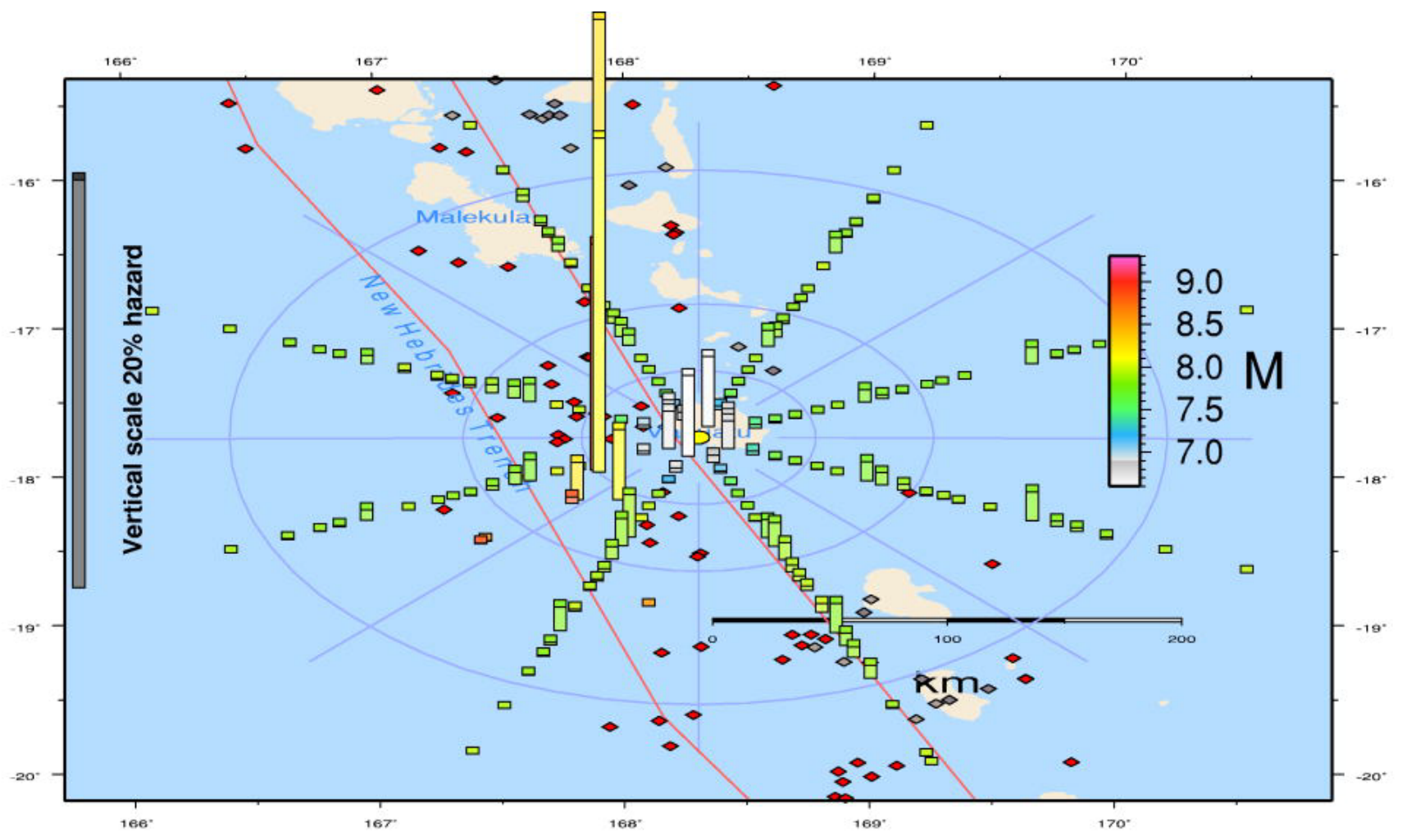

Figure 38. Deaggregation plots of a site at Port Vila, Vanuatu for 1 second (sec) (1 Hertz (Hz)) and $0.2 \mathrm{~s}(5 \mathrm{~Hz})$ spectral accelerations. $A$, Plot of percent contribution to hazard and mean return time in years showing the relative contribution to the overall hazard for different return times. The area between the curves represents the contribution of that source to the overall hazard for 1 and $0.2 \mathrm{~s}$ spectral accelerations at Pago Pago. B. Plot 1 second $(1 \mathrm{~Hz})$ showing the magnitudes, distances, and epsilons for 2 percent probability of exceedance in 50 years that contribute most to the hazard. $C$, Plot $0.2 \mathrm{~s}(5 \mathrm{~Hz})$ showing the magnitudes, distances, and epsilons for 2 percent probability of exceedance in 50 years that contribute most to the hazard. $D$, Geographic deaggregations that show the contributions of earthquake sources on a map to the1 $\mathrm{s}(1 \mathrm{~Hz})$ overall hazard. $E$, Geographic deaggregations that show the contributions of earthquake sources on a map to the $0.2 \mathrm{~s}(5 \mathrm{~Hz})$ overall hazard. (km, kilometers; SA, spectral acceleration; $\mathrm{g}$, acceleration of gravity; Mw, and M, represent moment magnitude) 
Table 1. b-values, maximum magnitudes, and rates of earthquakes applied in the hazard model. (NGA, Next Generation Attenuation Relations of Chiou and Youngs (2008), Campbell and Bozorgnia (2008), and Atkinson and Boore (2008); km, kilometers)

\begin{tabular}{|c|c|c|c|c|c|c|c|c|c|}
\hline Source Model (depth) & $\begin{array}{l}\text { Calculated } \\
\text { b-value }\end{array}$ & $\begin{array}{l}\text { b-value } \\
\text { standard } \\
\text { deviation }\end{array}$ & $\begin{array}{l}\text { Maximum } \\
\text { recorded } \\
\text { magnitude } \\
\text { since } 1900\end{array}$ & $\begin{array}{l}\text { Maximum } \\
\text { recorded } \\
\text { magnitude } \\
\text { since } 1964 \\
\end{array}$ & $\begin{array}{l}\text { Maximum } \\
\text { magnitude } \\
\quad \text { for } \\
\text { calculations }\end{array}$ & $\begin{array}{c}\text { Rate of } M \geq 7 \\
\text { since } 1900\end{array}$ & $\begin{array}{l}\text { Type of } \\
\text { source } \\
\text { S=smooth } \\
\text { F=fault }\end{array}$ & $\begin{array}{l}\text { Model source } \\
\text { depth }(\mathrm{km})\end{array}$ & $\begin{array}{l}\text { Ground motion } \\
\text { models }\end{array}$ \\
\hline Tonga Outer Rise $(0-50 \mathrm{~km})$ & 0.99 & 0.07 & 8.2 & $8.1\left(8.0^{*}\right)$ & 8.2 & & $\mathrm{~S}$ & 10 & $\begin{array}{l}\text { Crustal ZhaO and } \\
\text { NGA }\end{array}$ \\
\hline New Hebrides Outer Rise $(0-50 \mathrm{~km})$ & 1.11 & 0.10 & 7.7 & 7.7 & 8.2 & & $\mathrm{~S}$ & 10 & $\begin{array}{l}\text { Crustal Zhao and } \\
\text { NGA }\end{array}$ \\
\hline $\begin{array}{l}\text { Tonga Subduction Zone interface } \\
(0-50 \mathrm{~km})\end{array}$ & 0.87 & 0.03 & 8.5 & $7.9\left(8.0^{*}\right)$ & $\begin{array}{l}7.0 \text { (see } \\
\text { interface } \\
\text { zone } \\
\text { below) }\end{array}$ & & $\mathrm{S}$ & 10 & $\begin{array}{l}\text { Crustal Zhao and } \\
\text { NGA }\end{array}$ \\
\hline $\begin{array}{l}\text { New Hebrides Subduction Zone Interface } \\
(0-50 \mathrm{~km})\end{array}$ & 0.58 & 0.04 & 7.9 & 7.8 & $\begin{array}{l}7.0 \text { (see } \\
\text { interface } \\
\text { zone } \\
\text { below) }\end{array}$ & & $\mathrm{S}$ & 10 & $\begin{array}{l}\text { Crustal Zhao and } \\
\text { NGA }\end{array}$ \\
\hline Fiji zone $(0-50$ km) & 0.86 & 0.03 & 7.8 & 7.7 & 8.0 & & $\mathrm{~S}$ & 10 & $\begin{array}{l}\text { Crustal Zhao and } \\
\text { NGA }\end{array}$ \\
\hline Background (elsewhere; 0-50 km) & 1.01 & 0.07 & 7.1 & 7.1 & 7.3 & & $\mathrm{~S}$ & 10 & $\begin{array}{l}\text { Crustal Zhao and } \\
\text { NGA }\end{array}$ \\
\hline Background (50-100 km) & 0.93 & 0.05 & 8.2 & 8.1 & 8.2 & & $\mathrm{~S}$ & 75 & Intraslab \\
\hline Background (100-200 km) & 0.89 & 0.04 & 7.8 & 7.8 & 8.0 & & $\mathrm{~S}$ & 150 & Intraslab \\
\hline Background (200-300 km) & 0.95 & 0.05 & 7.9 & 7.1 & 8.0 & & $\mathrm{~S}$ & 250 & Intraslab \\
\hline Background (300-400 km) & 0.97 & 0.07 & 8.0 & 7.2 & 8.0 & & $\mathrm{~S}$ & 350 & Intraslab \\
\hline Background (400-500 km) & 1.16 & 0.09 & 7.5 & 7.3 & 8.0 & & $\mathrm{~S}$ & 450 & Intraslab \\
\hline Background (500-600 km) & 0.87 & 0.05 & 7.8 & 7.6 & 8.0 & & $\mathrm{~S}$ & 550 & Intraslab \\
\hline Background (600-723 km) & 0.87 & 0.07 & 7.7 & 7.7 & 8.0 & & $\mathrm{~S}$ & 650 & Intraslab \\
\hline $\begin{array}{l}\text { Tonga Subduction Zone Interface } \\
(0-50 \mathrm{~km}) \\
\text { M7-M9, 1900-2010 }\end{array}$ & $\begin{array}{c}0.87 \\
\text { (fixed)** }\end{array}$ & & 8.5 & $\begin{array}{c}7.9 \\
\left(8.0(\text { fixed })^{*}\right)\end{array}$ & $8.5,9.0$ & $\begin{array}{l}22 \text { events } \\
/ 110 \\
\text { years }\end{array}$ & $\mathrm{F}$ & $\begin{array}{l}\mathrm{H}=25, \text { top } \\
\text { of zone is } \\
10 \mathrm{~km}\end{array}$ & Inter-face \\
\hline $\begin{array}{l}\text { New Hebrides Subduction Zone Interface } \\
(0-50 \mathrm{~km}) \\
\text { M7-M9, 1900-2010 }\end{array}$ & $\begin{array}{c}1.0 \\
(\text { fixed)** }\end{array}$ & & 7.9 & 7.8 & $8.5,9.0$ & $\begin{array}{l}32 \text { events } \\
/ 110 \\
\text { years }\end{array}$ & $\mathrm{F}$ & $\begin{array}{l}\mathrm{H}=25 \text {, top } \\
\text { of zone is } \\
10 \mathrm{~km}\end{array}$ & Inter-face \\
\hline
\end{tabular}


Table 2. Earthquake and station information.

\begin{tabular}{|c|c|c|c|c|c|c|c|c|c|c|}
\hline $\begin{array}{l}\text { Earthquake origin } \\
\text { time }\end{array}$ & Magnitude & Latitude & Longitude & Strike & Depth & $\begin{array}{c}\text { Distance } \\
1\end{array}$ & $\begin{array}{c}\text { Distance } \\
2\end{array}$ & $\begin{array}{c}\text { Slab } \\
\text { (1=yes) }\end{array}$ & Station & Weight \\
\hline 19960819041916 & 6.0 & 51.45 & 181.63 & 80 & 33 & 131.2 & 127.3 & 1 & ADK. & 0.4203 \\
\hline 19990918212833 & 6.0 & 51.21 & 157.56 & 50 & 60 & 224.3 & 220.7 & 1 & PET. & .3193 \\
\hline 19991219004836 & 6.0 & 12.87 & 144.57 & 0 & 50 & 99.3 & 97.4 & 1 & GUMO & .4806 \\
\hline 20010201181930 & 6.0 & 51.44 & 182.2 & 80 & 33 & 97.1 & 94.6 & 1 & ADK. & .4876 \\
\hline 20021016141312 & 6.0 & -15.68 & 186.95 & 12 & 33 & 241.8 & 239.4 & 1 & AFI. & .3066 \\
\hline 20030610084030 & 6.0 & 23.52 & 121.63 & 20 & 44 & 167.4 & 165.5 & 1 & TATO & .3687 \\
\hline 20040414013305 & 6.0 & -17.85 & 185.44 & 12 & 143 & 548.1 & 546.1 & 1 & AFI. & .203 \\
\hline 20060430193318 & 6.0 & -15.52 & 186.9 & 12 & 10 & 228.6 & 226.4 & 1 & AFI. & .3153 \\
\hline 20060707072612 & 6.0 & -15.24 & 186.39 & 12 & 35 & 248.7 & 246.9 & 1 & AFI. & .3019 \\
\hline 20080728214047 & 6.0 & -10.58 & 163.1 & -60 & 10 & 368.9 & 365.1 & 1 & HNR. & .2483 \\
\hline 20090929175605 & 6.0 & -15.35 & 186.84 & 12 & 10 & 218.6 & 216.4 & 1 & AFI. & .3225 \\
\hline 20090929234503 & 6.0 & -15.83 & 187.45 & 12 & 10 & 228.6 & 226.5 & 1 & AFI. & .3152 \\
\hline 20091019224938 & 6.0 & -15.36 & 187.74 & 12 & 18 & 170.3 & 167.6 & 1 & AFI. & .3664 \\
\hline 20091128092117 & 6.0 & -29.22 & 182.98 & 12 & 28 & 93.4 & 92 & 1 & RAO. & .4946 \\
\hline 20100209010344 & 6.0 & -15.05 & 186.51 & 12 & 10 & 224.1 & 222 & 1 & AFI. & .3184 \\
\hline 20100804044620 & 6.0 & -26.92 & 182.76 & 12 & 18 & 266.9 & 264.9 & 1 & RAO. & .2914 \\
\hline 19980914231646 & 6.1 & 51.62 & 186.85 & 80 & 33 & 248.4 & 244 & 1 & ADK. & .3087 \\
\hline 20020128135028 & 6.1 & 49.38 & 155.59 & 50 & 33 & 460.2 & 455.8 & 1 & PET. & .2259 \\
\hline 20021126004815 & 6.1 & 51.47 & 186.46 & 80 & 20 & 223.7 & 219.4 & 1 & ADK. & .3256 \\
\hline 20050117105032 & 6.1 & 10.99 & 140.68 & 0 & 12 & 539.3 & 537.4 & 1 & GUMO & .208 \\
\hline 20050604145046 & 6.1 & -6.32 & 146.85 & 75 & 26 & 344.1 & 345.2 & 1 & PMG. & .2596 \\
\hline 20060401100219 & 6.1 & 22.87 & 121.28 & 20 & 9 & 234.1 & 231.8 & 1 & TATO & .3167 \\
\hline 20070402104917 & 6.1 & -7.22 & 156.24 & -60 & 34 & 478 & 474.5 & 1 & HNR. & .2214 \\
\hline 20070826123731 & 6.1 & -17.46 & 185.66 & 12 & 127 & 496.6 & 494.2 & 1 & AFI. & .2169 \\
\hline 20071006123849 & 6.1 & 18.73 & 147.15 & 0 & 20 & 619.7 & 618.6 & 1 & GUMO & .1939 \\
\hline 20080819163013 & 6.1 & -15.09 & 186.52 & 12 & 8 & 225.2 & 223.1 & 1 & AFI. & .3229 \\
\hline 20081102134842 & 6.1 & 51.55 & 185.63 & 80 & 36 & 168.8 & 164.5 & 1 & ADK. & .376 \\
\hline 20081121070534 & 6.1 & -8.95 & 159.55 & -60 & 118 & 136.7 & 135.5 & 1 & HNR. & .4143 \\
\hline 20090817101056 & 6.1 & 23.43 & 123.52 & 20 & 15 & 267.8 & 266.7 & 1 & TATO & .2953 \\
\hline 20091002010739 & 6.1 & -16.33 & 186.53 & 12 & 8 & 324.3 & 321.7 & 1 & AFI. & .2689 \\
\hline 20091003173606 & 6.1 & 23.63 & 121.45 & 20 & 28 & 151.9 & 148.9 & 1 & TATO & .3952 \\
\hline 20091128181020 & 6.1 & 5.33 & 126.29 & -15 & 38 & 211.8 & 208.9 & 1 & DAV. & .3337 \\
\hline 20100213023428 & 6.1 & -21.9 & 185.23 & 12 & 11 & 874.6 & 872.6 & 1 & RAO. & .1633 \\
\hline 20100421172029 & 6.1 & -15.27 & 186.78 & 12 & 35 & 218.9 & 216.8 & 1 & AFI. & .3275 \\
\hline 20100624053227 & 6.1 & -5.51 & 151.16 & 75 & 40 & 618.5 & 616.4 & 1 & PMG. & .1942 \\
\hline 20101123090106 & 6.1 & -5.96 & 148.97 & 75 & 68 & 435.3 & 434.9 & 1 & PMG. & .2312 \\
\hline 19961203125656 & 6.2 & -18.35 & 187.73 & 12 & 32 & 495.6 & 493.6 & 1 & AFI. & .2206 \\
\hline 20000421043517 & 6.2 & 51.42 & 181.86 & 80 & 33 & 118.3 & 113.9 & 1 & ADK. & .4593 \\
\hline
\end{tabular}


Table 2. Earthquake and station information.-Continued

\begin{tabular}{|c|c|c|c|c|c|c|c|c|c|c|}
\hline $\begin{array}{l}\text { Earthquake origin } \\
\text { time }\end{array}$ & Magnitude & Latitude & Longitude & Strike & Depth & $\begin{array}{c}\text { Distance } \\
1\end{array}$ & $\begin{array}{c}\text { Distance } \\
2\end{array}$ & $\begin{array}{c}\text { Slab } \\
(1=y e s)\end{array}$ & Station & Weight \\
\hline 20001219131147 & 6.2 & 11.77 & 144.76 & 0 & 33 & 204.3 & 201.3 & 1 & GUMO & .3454 \\
\hline 20011002004818 & 6.2 & -16.18 & 186.18 & 12 & 106 & 350.6 & 347.5 & 1 & AFI. & .2629 \\
\hline 20030317185547 & 6.2 & 51.29 & 177.97 & 80 & 33 & 379.1 & 372.5 & 1 & ADK. & .254 \\
\hline 20030328173147 & 6.2 & -15.32 & 186.49 & 12 & 41 & 247.4 & 244 & 1 & AFI. & .3138 \\
\hline 20030503050303 & 6.2 & -15.14 & 186.25 & 12 & 33 & 255 & 252 & 1 & AFI. & .3088 \\
\hline 20031007045528 & 6.2 & -16.53 & 189.81 & 12 & 10 & 336.6 & 334.7 & 1 & AFI. & .2679 \\
\hline 20040519070411 & 6.2 & 22.66 & 121.5 & 20 & 20 & 257 & 254.3 & 1 & TATO & .3074 \\
\hline 20040903190447 & 6.2 & -15.25 & 186.66 & 12 & 10 & 225.2 & 221.7 & 1 & AFI. & .3292 \\
\hline 20050518102706 & 6.2 & -15.32 & 186.76 & 12 & 10 & 221.9 & 219.1 & 1 & AFI. & .3312 \\
\hline 20070402120223 & 6.2 & -8.71 & 157.62 & -60 & 14 & 268.8 & 264.5 & 1 & HNR. & .3014 \\
\hline 20070402232023 & 6.2 & -8.62 & 157.39 & -60 & 18 & 295.8 & 291.9 & 1 & HNR. & .2869 \\
\hline 20070906175126 & 6.2 & 24.34 & 122.22 & 20 & 53 & 114.4 & 113.1 & 1 & TATO & .4609 \\
\hline 20080603162050 & 6.2 & -10.51 & 161.27 & -60 & 84 & 205.1 & 201.9 & 1 & HNR. & .345 \\
\hline 20100109055130 & 6.2 & -9.13 & 157.63 & -60 & 12 & 257.6 & 253.2 & 1 & HNR. & .308 \\
\hline 19950116181449 & 6.3 & 51.26 & 179.17 & 80 & 33 & 298.2 & 291.9 & 1 & ADK. & .2915 \\
\hline 20000126132650 & 6.3 & -17.27 & 186 & 12 & 33 & 443.5 & 439.9 & 1 & AFI. & .2375 \\
\hline 20010802234106 & 6.3 & 56.26 & 163.79 & 50 & 14 & 491.5 & 484 & 1 & PET. & .2264 \\
\hline 20031022114530 & 6.3 & -6.06 & 147.73 & 75 & 53 & 379.1 & 379 & 1 & PMG. & .2558 \\
\hline 20040109223531 & 6.3 & -6.07 & 149.4 & 75 & 57 & 448.1 & 445.6 & 1 & PMG. & .236 \\
\hline 20050202023025 & 6.3 & 14.08 & 144.71 & 0 & 158 & 167.9 & 166.5 & 1 & GUMO & .3859 \\
\hline 20060214152723 & 6.3 & 20.82 & 146.18 & 0 & 40 & 814.2 & 812.3 & 1 & GUMO & .1748 \\
\hline 20100207061000 & 6.3 & 23.49 & 123.61 & 20 & 21 & 271.5 & 269.8 & 1 & TATO & .3032 \\
\hline 20100304001851 & 6.3 & 22.92 & 120.79 & 20 & 21 & 239.3 & 235.6 & 1 & TATO & .3245 \\
\hline 20100710114332 & 6.3 & 11.14 & 146 & 0 & 13 & 297.7 & 294.8 & 1 & GUMO & .2901 \\
\hline 20101004132838 & 6.3 & 24.27 & 125.15 & 20 & 32 & 380.1 & 378.2 & 1 & TATO & .2561 \\
\hline 19991207212949 & 6.4 & -15.91 & 186.02 & 12 & 137 & 351.9 & 348.3 & 1 & AFI. & .2711 \\
\hline 20030314125412 & 6.4 & -17.42 & 184.82 & 12 & 274 & 599.8 & 595.9 & 1 & AFI. & .2073 \\
\hline 20030902182800 & 6.4 & -15.23 & 186.78 & 12 & 10 & 214.1 & 209.4 & 1 & AFI. & .3497 \\
\hline 20050122203017 & 6.4 & -7.73 & 159.48 & -60 & 29 & 198.2 & 195.1 & 1 & HNR. & .3623 \\
\hline 20051015155108 & 6.4 & 25.31 & 123.35 & 20 & 192 & 270.5 & 268.3 & 1 & TATO & .3089 \\
\hline 20070404063435 & 6.4 & -7.76 & 156.49 & -60 & 17 & 423.7 & 418.2 & 1 & HNR. & .2474 \\
\hline 20090118141148 & 6.4 & -30.2 & 182.05 & 12 & 33 & 110.9 & 106 & 1 & RAO. & .4915 \\
\hline 20091219130217 & 6.4 & 23.8 & 121.61 & 20 & 57 & 142.3 & 138.2 & 1 & TATO & .4304 \\
\hline 19960608231915 & 6.5 & 51.49 & 181.87 & 80 & 33 & 114.1 & 107.6 & 1 & ADK. & .4954 \\
\hline 20010703131042 & 6.5 & 21.64 & 142.98 & 0 & 290 & 959.5 & 955.9 & 1 & GUMO & .1662 \\
\hline 20020814135752 & 6.5 & 14.1 & 146.2 & 0 & 30 & 157.7 & 155.2 & 1 & GUMO & .4125 \\
\hline 20070816083928 & 6.5 & -9.83 & 159.46 & -60 & 15 & 70.7 & 68.5 & 1 & HNR. & .6209 \\
\hline 20090516005351 & 6.5 & -31.55 & 181.17 & 12 & 43 & 274.1 & 267.4 & 1 & RAO. & .3143 \\
\hline
\end{tabular}


Table 2. Earthquake and station information.-Continued

\begin{tabular}{|c|c|c|c|c|c|c|c|c|c|c|}
\hline $\begin{array}{c}\text { Earthquake origin } \\
\text { time }\end{array}$ & Magnitude & Latitude & Longitude & Strike & Depth & $\begin{array}{c}\text { Distance } \\
1\end{array}$ & $\begin{array}{c}\text { Distance } \\
2\end{array}$ & $\begin{array}{c}\text { Slab } \\
(1=y e s)\end{array}$ & Station & Weight \\
\hline 20100426025951 & 6.5 & 22.18 & 123.63 & 20 & 14 & 379 & 375.6 & 1 & TATO & .2652 \\
\hline 19971217043851 & 6.6 & 51.19 & 178.87 & 80 & 20 & 319.2 & 309.8 & 1 & ADK. & .2964 \\
\hline 19990128081005 & 6.6 & 52.89 & 190.88 & 80 & 67 & 532.3 & 521.7 & 1 & ADK. & .2284 \\
\hline 20021107151406 & 6.6 & 51.2 & 179.33 & 80 & 33 & 289.3 & 280.1 & 1 & ADK. & .3118 \\
\hline 20031125201946 & 6.6 & -5.58 & 150.88 & 75 & 35 & 591.5 & 585.2 & 1 & PMG. & .2157 \\
\hline 20050116201752 & 6.6 & 10.93 & 140.84 & 0 & 24 & 528.6 & 524.4 & 1 & GUMO & .2279 \\
\hline 20050205033425 & 6.6 & 16.01 & 145.87 & 0 & 142 & 321.6 & 316.3 & 1 & GUMO & .2934 \\
\hline 20070130213744 & 6.6 & 20.98 & 144.71 & 0 & 20 & 819 & 814.4 & 1 & GUMO & .1828 \\
\hline 20071127114958 & 6.6 & -10.95 & 162.15 & -60 & 16 & 294.5 & 286.5 & 1 & HNR. & .3083 \\
\hline 20080719092701 & 6.6 & -11.04 & 164.49 & -60 & 11 & 529.3 & 520.4 & 1 & HNR. & .2287 \\
\hline 20090830145132 & 6.6 & -15.22 & 187.43 & 12 & 11 & 168.6 & 161.9 & 1 & AFI. & .4101 \\
\hline 20100103214805 & 6.6 & -8.74 & 157.48 & -60 & 26 & 283 & 275.5 & 1 & HNR. & .3144 \\
\hline 20040125114311 & 6.7 & -16.83 & 185.8 & 12 & 129 & 435.1 & 427.6 & 1 & AFI. & .2562 \\
\hline 20050208144821 & 6.7 & -14.25 & 167.26 & -16 & 206 & 981 & 973.8 & 1 & HNR. & .1697 \\
\hline 20100626053019 & 6.7 & -10.63 & 161.45 & -60 & 35 & 214.5 & 205.1 & 1 & HNR. & .3698 \\
\hline 19960322032420 & 6.8 & 51.22 & 178.7 & 80 & 20 & 330.4 & 317.3 & 1 & ADK. & .3018 \\
\hline 20031210043811 & 6.8 & 23.04 & 121.36 & 20 & 10 & 215.2 & 205.3 & 1 & TATO & .3752 \\
\hline 20041008082753 & 6.8 & -10.95 & 162.16 & -60 & 36 & 297.4 & 286.2 & 1 & HNR. & .3178 \\
\hline 20080509215129 & 6.8 & 12.52 & 143.18 & 0 & 76 & 231.2 & 225.6 & 1 & GUMO & .3579 \\
\hline 20081209062359 & 6.8 & -31.23 & 183.08 & 12 & 18 & 241.3 & 233 & 1 & RAO. & .3522 \\
\hline 20091124124715 & 6.8 & -20.71 & 185.96 & 12 & 18 & 791.1 & 782.8 & 1 & AFI. & .1921 \\
\hline 20091124124716 & 6.8 & -20.71 & 185.96 & 12 & 18 & 785.6 & 782.8 & 1 & AFI. & .1921 \\
\hline 20100105121532 & 6.8 & -9.02 & 157.55 & -60 & 15 & 267.8 & 257.5 & 1 & HNR. & .335 \\
\hline 20100411094025 & 6.8 & -10.88 & 161.12 & -60 & 21 & 206 & 196.3 & 1 & HNR. & .3837 \\
\hline 20060928062209 & 6.9 & -16.59 & 187.97 & 12 & 28 & 299.9 & 287.9 & 1 & AFI. & .3215 \\
\hline 20061226123413 & 6.9 & 21.97 & 120.49 & 20 & 10 & 348.8 & 336.7 & 1 & TATO & .2973 \\
\hline 20070930020830 & 6.9 & 10.45 & 145.72 & 0 & 14 & 360.1 & 349 & 1 & GUMO & .292 \\
\hline 20080908185206 & 6.9 & -13.5 & 166.97 & -16 & 110 & 895.8 & 886.1 & 1 & HNR. & .1832 \\
\hline 20100718130409 & 6.9 & -5.97 & 150.43 & 75 & 28 & 525.4 & 515 & 1 & PMG. & .2404 \\
\hline 20011012150216 & 7.0 & 12.69 & 144.98 & 0 & 37 & 106.9 & 93.3 & 0 & GUMO & .5728 \\
\hline 20090218215345 & 7.0 & -27.42 & 183.67 & 12 & 25 & 257.4 & 243.9 & 1 & RAO. & .3543 \\
\hline 20020426160607 & 7.1 & 13.09 & 144.62 & 0 & 85 & 104.8 & 96.8 & 1 & GUMO & .5706 \\
\hline 20030317163617 & 7.1 & 51.27 & 177.98 & 80 & 33 & 379.1 & 358.5 & 0 & ADK. & .2964 \\
\hline 20100103223627 & 7.1 & -8.8 & 157.35 & -60 & 25 & 295.2 & 277.8 & 0 & HNR. & .3367 \\
\hline 20000108164720 & 7.2 & -16.92 & 185.75 & 12 & 183 & 464.3 & 447.4 & 1 & AFI. & .2691 \\
\hline 20071031033015 & 7.2 & 18.9 & 145.39 & 0 & 207 & 625.7 & 608.4 & 1 & GUMO & .2308 \\
\hline 20071219093027 & 7.2 & 51.36 & 180.49 & 80 & 34 & 207.8 & 185.8 & 0 & ADK. & .4176 \\
\hline 19960610152456 & 7.3 & 51.48 & 183.15 & 80 & 26 & 53.5 & 49.5 & 0 & ADK. & .8205 \\
\hline
\end{tabular}


Table 2. Earthquake and station information.-Continued

\begin{tabular}{ccccccccccc}
\hline $\begin{array}{c}\text { Earthquake origin } \\
\text { time }\end{array}$ & Magnitude & Latitude & Longitude & Strike & Depth & $\begin{array}{c}\text { Distance } \\
\mathbf{1}\end{array}$ & $\begin{array}{c}\text { Distance } \\
\mathbf{2}\end{array}$ & $\begin{array}{c}\text { Slab } \\
\text { (1=yes) }\end{array}$ & Station & Weight \\
\hline 20100718133459 & 7.3 & -5.93 & 150.59 & 75 & 35 & 541.4 & 520.4 & 0 & PMG. & .253 \\
\hline 20070928133857 & 7.5 & 22.01 & 142.67 & 0 & 260 & 995.9 & 966.8 & 1 & GUMO & .1907 \\
\hline 20090319181740 & 7.6 & -23.04 & 185.34 & 12 & 31 & 762.6 & 723.9 & 1 & RAO. & .2233 \\
\hline 20091007220314 & 7.7 & -13.01 & 166.51 & -16 & 45 & 820 & 786.7 & 0 & HNR. & .217 \\
\hline 20031117064306 & 7.8 & 51.15 & 178.65 & 80 & 33 & 336.9 & 278.2 & 1 & ADK. & .3697 \\
\hline 19960610040335 & 7.9 & 51.56 & 182.37 & 80 & 33 & 81.6 & 41.2 & 0 & ADK. & .9735 \\
\hline 20060503152640 & 8.0 & -20.19 & 185.88 & 12 & 55 & 741.7 & 665.1 & 1 & AFI. & .2452 \\
\hline 20070401203958 & 8.1 & -8.47 & 157.04 & -60 & 24 & 338.4 & 246.8 & 0 & HNR. & .4076 \\
\hline 20090929174810 & 8.0 & -15.49 & 187.9 & 12 & 18 & 179.1 & 101.3 & 1 & AFI. & .6284 \\
\hline
\end{tabular}


Table 3. 1-second spectral acceleration.

\begin{tabular}{|c|c|c|c|c|c|}
\hline Earthquake origin time & Observed & AB-Cascadia & AB-Global & Geomatrix & $\begin{array}{l}\text { Zhao and others } \\
(2006)\end{array}$ \\
\hline 19960819041916 & $5.40 \mathrm{E}-03$ & $3.60 \mathrm{E}-03$ & $3.27 \mathrm{E}-03$ & $1.24 \mathrm{E}-02$ & $4.72 \mathrm{E}-03$ \\
\hline 19990918212833 & $1.58 \mathrm{E}-03$ & $1.04 \mathrm{E}-03$ & $9.41 \mathrm{E}-04$ & $5.28 \mathrm{E}-03$ & $2.21 \mathrm{E}-03$ \\
\hline 19991219004836 & $1.29 \mathrm{E}-02$ & $6.79 \mathrm{E}-03$ & $6.17 \mathrm{E}-03$ & $1.81 \mathrm{E}-02$ & 8.93E-03 \\
\hline 20010201181930 & $1.24 \mathrm{E}-02$ & $6.86 \mathrm{E}-03$ & $6.24 \mathrm{E}-03$ & $1.88 \mathrm{E}-02$ & 7.91E-03 \\
\hline 20021016141312 & $2.32 \mathrm{E}-03$ & $7.70 \mathrm{E}-04$ & $7.00 \mathrm{E}-04$ & $4.61 \mathrm{E}-03$ & $1.43 \mathrm{E}-03$ \\
\hline 20030610084030 & $5.02 \mathrm{E}-03$ & $2.03 \mathrm{E}-03$ & $1.84 \mathrm{E}-03$ & 8.37E-03 & $3.27 \mathrm{E}-03$ \\
\hline 20040414013305 & $3.33 \mathrm{E}-03$ & $7.51 \mathrm{E}-05$ & $6.83 \mathrm{E}-05$ & $1.07 \mathrm{E}-03$ & $5.31 \mathrm{E}-04$ \\
\hline 20060430193318 & 7.49E-04 & 8.34E-04 & $7.58 \mathrm{E}-04$ & $5.06 \mathrm{E}-03$ & $1.27 \mathrm{E}-03$ \\
\hline 20060707072612 & $2.29 \mathrm{E}-03$ & 7.12E-04 & $6.48 \mathrm{E}-04$ & $4.38 \mathrm{E}-03$ & $1.37 \mathrm{E}-03$ \\
\hline 20080728214047 & $2.39 \mathrm{E}-04$ & 2.09E-04 & $1.90 \mathrm{E}-04$ & $2.23 \mathrm{E}-03$ & 4.56E-04 \\
\hline 20090929175605 & $1.37 \mathrm{E}-03$ & $9.39 \mathrm{E}-04$ & $8.54 \mathrm{E}-04$ & $5.45 \mathrm{E}-03$ & $1.39 \mathrm{E}-03$ \\
\hline 20090929234503 & $1.03 \mathrm{E}-03$ & 8.33E-04 & 7.57E-04 & $5.05 \mathrm{E}-03$ & $1.27 \mathrm{E}-03$ \\
\hline 20091019224938 & 4.17E-03 & $1.82 \mathrm{E}-03$ & $1.66 \mathrm{E}-03$ & $8.21 \mathrm{E}-03$ & $2.46 \mathrm{E}-03$ \\
\hline 20091128092117 & $1.15 \mathrm{E}-02$ & $7.18 \mathrm{E}-03$ & $6.52 \mathrm{E}-03$ & $1.95 \mathrm{E}-02$ & 7.89E-03 \\
\hline 20100209010344 & $8.22 \mathrm{E}-04$ & $8.78 \mathrm{E}-04$ & 7.99E-04 & $5.23 \mathrm{E}-03$ & $1.32 \mathrm{E}-03$ \\
\hline 20100804044620 & 4.65E-03 & 5.57E-04 & 5.07E-04 & $3.89 \mathrm{E}-03$ & $9.99 \mathrm{E}-04$ \\
\hline 19980914231646 & $6.20 \mathrm{E}-04$ & $9.14 \mathrm{E}-04$ & 8.31E-04 & $5.20 \mathrm{E}-03$ & $1.61 \mathrm{E}-03$ \\
\hline 20020128135028 & $7.16 \mathrm{E}-04$ & $1.33 \mathrm{E}-04$ & $1.21 \mathrm{E}-04$ & $1.76 \mathrm{E}-03$ & $3.94 \mathrm{E}-04$ \\
\hline 20021126004815 & $1.73 \mathrm{E}-03$ & $1.17 \mathrm{E}-03$ & $1.06 \mathrm{E}-03$ & $6.20 \mathrm{E}-03$ & $1.75 \mathrm{E}-03$ \\
\hline 20050117105032 & $1.30 \mathrm{E}-04$ & $6.78 \mathrm{E}-05$ & $6.16 \mathrm{E}-05$ & $1.30 \mathrm{E}-03$ & $2.08 \mathrm{E}-04$ \\
\hline 20050604145046 & $8.18 \mathrm{E}-04$ & $3.28 \mathrm{E}-04$ & $2.98 \mathrm{E}-04$ & $2.88 \mathrm{E}-03$ & 7.12E-04 \\
\hline 20060401100219 & $4.46 \mathrm{E}-03$ & $9.77 \mathrm{E}-04$ & $8.88 \mathrm{E}-04$ & $5.66 \mathrm{E}-03$ & $1.40 \mathrm{E}-03$ \\
\hline 20070402104917 & $5.08 \mathrm{E}-04$ & $1.15 \mathrm{E}-04$ & $1.05 \mathrm{E}-04$ & $1.63 \mathrm{E}-03$ & $3.59 \mathrm{E}-04$ \\
\hline 20070826123731 & $1.03 \mathrm{E}-03$ & $1.31 \mathrm{E}-04$ & $1.19 \mathrm{E}-04$ & $1.52 \mathrm{E}-03$ & $8.08 \mathrm{E}-04$ \\
\hline 20071006123849 & 7.38E-04 & $3.93 \mathrm{E}-05$ & $3.58 \mathrm{E}-05$ & $1.00 \mathrm{E}-03$ & $1.53 \mathrm{E}-04$ \\
\hline 20080819163013 & $1.36 \mathrm{E}-03$ & $1.08 \mathrm{E}-03$ & $9.79 \mathrm{E}-04$ & $6.03 \mathrm{E}-03$ & $1.50 \mathrm{E}-03$ \\
\hline 20081102134842 & $1.55 \mathrm{E}-03$ & $2.51 \mathrm{E}-03$ & $2.28 \mathrm{E}-03$ & $9.77 \mathrm{E}-03$ & $3.56 \mathrm{E}-03$ \\
\hline 20081121070534 & $5.63 \mathrm{E}-03$ & $5.04 \mathrm{E}-03$ & $4.58 \mathrm{E}-03$ & $1.31 \mathrm{E}-02$ & $1.16 \mathrm{E}-02$ \\
\hline 20090817101056 & 4.54E-04 & $6.78 \mathrm{E}-04$ & $6.17 \mathrm{E}-04$ & $4.48 \mathrm{E}-03$ & 1.12E-03 \\
\hline 20091002010739 & $7.10 \mathrm{E}-04$ & $3.85 \mathrm{E}-04$ & $3.50 \mathrm{E}-04$ & $3.25 \mathrm{E}-03$ & $6.95 \mathrm{E}-04$ \\
\hline 20091003173606 & 4.91E-03 & $3.10 \mathrm{E}-03$ & $2.82 \mathrm{E}-03$ & $1.14 \mathrm{E}-02$ & $3.95 \mathrm{E}-03$ \\
\hline 20091128181020 & 2.32E-03 & $1.40 \mathrm{E}-03$ & $1.27 \mathrm{E}-03$ & $6.71 \mathrm{E}-03$ & $2.30 \mathrm{E}-03$ \\
\hline 20100213023428 & $2.00 \mathrm{E}-05$ & $7.66 \mathrm{E}-06$ & $6.96 \mathrm{E}-06$ & $5.26 \mathrm{E}-04$ & $4.75 \mathrm{E}-05$ \\
\hline 20100421172029 & 4.44E-03 & $1.26 \mathrm{E}-03$ & $1.14 \mathrm{E}-03$ & $6.32 \mathrm{E}-03$ & $2.08 \mathrm{E}-03$ \\
\hline 20100624053227 & $3.55 \mathrm{E}-04$ & 4.24E-05 & $3.85 \mathrm{E}-05$ & $1.01 \mathrm{E}-03$ & $1.88 \mathrm{E}-04$ \\
\hline 20101123090106 & 4.40E-04 & $1.74 \mathrm{E}-04$ & $1.58 \mathrm{E}-04$ & $1.91 \mathrm{E}-03$ & $6.29 \mathrm{E}-04$ \\
\hline 19961203125656 & $1.55 \mathrm{E}-03$ & $1.25 \mathrm{E}-04$ & $1.13 \mathrm{E}-04$ & $1.78 \mathrm{E}-03$ & $3.72 \mathrm{E}-04$ \\
\hline 20000421043517 & 4.34E-03 & $7.16 \mathrm{E}-03$ & $6.51 \mathrm{E}-03$ & 1.91E-02 & $7.82 \mathrm{E}-03$ \\
\hline
\end{tabular}


Table 3. 1-second spectral acceleration.-Continued

\begin{tabular}{|c|c|c|c|c|c|}
\hline Earthquake origin time & Observed & AB-Cascadia & AB-Global & Geomatrix & $\begin{array}{l}\text { Zhao and others } \\
(2006)\end{array}$ \\
\hline 20001219131147 & $2.45 \mathrm{E}-03$ & $1.89 \mathrm{E}-03$ & $1.72 \mathrm{E}-03$ & $8.25 \mathrm{E}-03$ & $2.75 \mathrm{E}-03$ \\
\hline 20011002004818 & $1.32 \mathrm{E}-03$ & $5.11 \mathrm{E}-04$ & $4.65 \mathrm{E}-04$ & $3.33 \mathrm{E}-03$ & $1.83 \mathrm{E}-03$ \\
\hline 20030317185547 & $8.09 \mathrm{E}-04$ & $3.30 \mathrm{E}-04$ & $3.00 \mathrm{E}-04$ & $2.95 \mathrm{E}-03$ & $7.49 \mathrm{E}-04$ \\
\hline 20030328173147 & 7.87E-03 & $1.17 \mathrm{E}-03$ & $1.07 \mathrm{E}-03$ & $6.05 \mathrm{E}-03$ & $2.04 \mathrm{E}-03$ \\
\hline 20030503050303 & 2.19E-03 & $1.05 \mathrm{E}-03$ & $9.53 \mathrm{E}-04$ & $5.74 \mathrm{E}-03$ & $1.76 \mathrm{E}-03$ \\
\hline 20031007045528 & $1.30 \mathrm{E}-03$ & $4.31 \mathrm{E}-04$ & $3.91 \mathrm{E}-04$ & $3.55 \mathrm{E}-03$ & $7.59 \mathrm{E}-04$ \\
\hline 20040519070411 & $1.77 \mathrm{E}-03$ & $9.84 \mathrm{E}-04$ & 8.94E-04 & $5.65 \mathrm{E}-03$ & $1.51 \mathrm{E}-03$ \\
\hline 20040903190447 & $1.41 \mathrm{E}-03$ & $1.38 \mathrm{E}-03$ & $1.25 \mathrm{E}-03$ & 7.07E-03 & $1.81 \mathrm{E}-03$ \\
\hline 20050518102706 & $1.10 \mathrm{E}-03$ & $1.42 \mathrm{E}-03$ & $1.29 \mathrm{E}-03$ & $7.21 \mathrm{E}-03$ & $1.85 \mathrm{E}-03$ \\
\hline 20070402120223 & 4.33E-03 & 8.66E-04 & $7.87 \mathrm{E}-04$ & $5.29 \mathrm{E}-03$ & $1.31 \mathrm{E}-03$ \\
\hline 20070402232023 & $2.36 \mathrm{E}-03$ & $6.63 \mathrm{E}-04$ & $6.03 \mathrm{E}-04$ & 4.49E-03 & $1.11 \mathrm{E}-03$ \\
\hline 20070906175126 & $8.51 \mathrm{E}-03$ & $7.71 \mathrm{E}-03$ & $7.01 \mathrm{E}-03$ & $1.93 \mathrm{E}-02$ & $9.68 \mathrm{E}-03$ \\
\hline 20080603162050 & $6.98 \mathrm{E}-03$ & $2.19 \mathrm{E}-03$ & $1.99 \mathrm{E}-03$ & $8.22 \mathrm{E}-03$ & $4.57 \mathrm{E}-03$ \\
\hline 20100109055130 & $1.86 \mathrm{E}-03$ & $9.72 \mathrm{E}-04$ & $8.83 \mathrm{E}-04$ & $5.69 \mathrm{E}-03$ & $1.41 \mathrm{E}-03$ \\
\hline 19950116181449 & $1.43 \mathrm{E}-03$ & $8.68 \mathrm{E}-04$ & 7.89E-04 & $5.22 \mathrm{E}-03$ & $1.51 \mathrm{E}-03$ \\
\hline 20000126132650 & $6.75 \mathrm{E}-04$ & $2.37 \mathrm{E}-04$ & $2.16 \mathrm{E}-04$ & $2.57 \mathrm{E}-03$ & $5.88 \mathrm{E}-04$ \\
\hline 20010802234106 & $2.47 \mathrm{E}-04$ & $1.59 \mathrm{E}-04$ & $1.45 \mathrm{E}-04$ & $2.16 \mathrm{E}-03$ & $3.82 \mathrm{E}-04$ \\
\hline 20031022114530 & $6.13 \mathrm{E}-04$ & $4.15 \mathrm{E}-04$ & $3.77 \mathrm{E}-04$ & $3.34 \mathrm{E}-03$ & $1.03 \mathrm{E}-03$ \\
\hline 20040109223531 & $2.25 \mathrm{E}-04$ & $2.44 \mathrm{E}-04$ & $2.21 \mathrm{E}-04$ & $2.51 \mathrm{E}-03$ & $7.25 \mathrm{E}-04$ \\
\hline 20050202023025 & $1.56 \mathrm{E}-02$ & $5.47 \mathrm{E}-03$ & 4.97E-03 & $1.27 \mathrm{E}-02$ & $1.16 \mathrm{E}-02$ \\
\hline 20060214152723 & $9.80 \mathrm{E}-05$ & $1.90 \mathrm{E}-05$ & $1.73 \mathrm{E}-05$ & $8.35 \mathrm{E}-04$ & $1.10 \mathrm{E}-04$ \\
\hline 20100207061000 & $1.26 \mathrm{E}-03$ & $1.05 \mathrm{E}-03$ & $9.52 \mathrm{E}-04$ & $5.95 \mathrm{E}-03$ & $1.58 \mathrm{E}-03$ \\
\hline 20100304001851 & $6.58 \mathrm{E}-03$ & $1.52 \mathrm{E}-03$ & $1.38 \mathrm{E}-03$ & $7.43 \mathrm{E}-03$ & $2.09 \mathrm{E}-03$ \\
\hline 20100710114332 & $1.39 \mathrm{E}-03$ & 7.95E-04 & $7.23 \mathrm{E}-04$ & $5.13 \mathrm{E}-03$ & $1.21 \mathrm{E}-03$ \\
\hline 20101004132838 & $3.52 \mathrm{E}-04$ & $3.92 \mathrm{E}-04$ & $3.57 \mathrm{E}-04$ & $3.35 \mathrm{E}-03$ & $8.37 \mathrm{E}-04$ \\
\hline 19991207212949 & $6.52 \mathrm{E}-03$ & $8.74 \mathrm{E}-04$ & 7.94E-04 & 4.49E-03 & $3.01 \mathrm{E}-03$ \\
\hline 20030314125412 & $8.54 \mathrm{E}-04$ & $1.95 \mathrm{E}-04$ & $1.77 \mathrm{E}-04$ & $1.74 \mathrm{E}-03$ & 7.79E-04 \\
\hline 20030902182800 & 4.78E-03 & $2.49 \mathrm{E}-03$ & $2.27 \mathrm{E}-03$ & $1.03 \mathrm{E}-02$ & $2.76 \mathrm{E}-03$ \\
\hline 20050122203017 & $2.71 \mathrm{E}-03$ & $3.16 \mathrm{E}-03$ & $2.87 \mathrm{E}-03$ & $1.15 \mathrm{E}-02$ & $3.84 \mathrm{E}-03$ \\
\hline 20051015155108 & $1.20 \mathrm{E}-03$ & $2.22 \mathrm{E}-03$ & $2.02 \mathrm{E}-03$ & $6.96 \mathrm{E}-03$ & $5.32 \mathrm{E}-03$ \\
\hline 20070404063435 & $3.33 \mathrm{E}-03$ & $3.37 \mathrm{E}-04$ & $3.06 \mathrm{E}-04$ & $3.27 \mathrm{E}-03$ & $6.63 \mathrm{E}-04$ \\
\hline 20090118141148 & $3.00 \mathrm{E}-02$ & $1.29 \mathrm{E}-02$ & $1.18 \mathrm{E}-02$ & $2.72 \mathrm{E}-02$ & $1.21 \mathrm{E}-02$ \\
\hline 20091219130217 & $1.58 \mathrm{E}-02$ & 7.77E-03 & $7.06 \mathrm{E}-03$ & $1.91 \mathrm{E}-02$ & $9.64 \mathrm{E}-03$ \\
\hline 19960608231915 & $1.58 \mathrm{E}-02$ & $1.56 \mathrm{E}-02$ & $1.41 \mathrm{E}-02$ & $3.02 \mathrm{E}-02$ & $1.38 \mathrm{E}-02$ \\
\hline 20010703131042 & $2.41 \mathrm{E}-04$ & $2.71 \mathrm{E}-05$ & $2.46 \mathrm{E}-05$ & $8.47 \mathrm{E}-04$ & $2.03 \mathrm{E}-04$ \\
\hline 20020814135752 & $9.44 \mathrm{E}-03$ & $6.84 \mathrm{E}-03$ & $6.22 \mathrm{E}-03$ & $1.85 \mathrm{E}-02$ & $6.96 \mathrm{E}-03$ \\
\hline 20070816083928 & $1.50 \mathrm{E}-01$ & $3.66 \mathrm{E}-02$ & $3.33 \mathrm{E}-02$ & $5.07 \mathrm{E}-02$ & $2.44 \mathrm{E}-02$ \\
\hline 20090516005351 & 4.67E-03 & $1.80 \mathrm{E}-03$ & $1.63 \mathrm{E}-03$ & 8.09E-03 & $2.75 \mathrm{E}-03$ \\
\hline 20100426025951 & $3.94 \mathrm{E}-03$ & $5.97 \mathrm{E}-04$ & $5.43 \mathrm{E}-04$ & $4.59 \mathrm{E}-03$ & $9.72 \mathrm{E}-04$ \\
\hline
\end{tabular}


Table 3. 1-second spectral acceleration.-Continued

\begin{tabular}{|c|c|c|c|c|c|}
\hline Earthquake origin time & Observed & AB-Cascadia & AB-Global & Geomatrix & $\begin{array}{l}\text { Zhao and others } \\
(2006)\end{array}$ \\
\hline 19971217043851 & $2.29 \mathrm{E}-03$ & $1.38 \mathrm{E}-03$ & $1.25 \mathrm{E}-03$ & $7.34 \mathrm{E}-03$ & $1.87 \mathrm{E}-03$ \\
\hline 19990128081005 & $1.14 \mathrm{E}-03$ & 2.79E-04 & $2.53 \mathrm{E}-04$ & $3.00 \mathrm{E}-03$ & $8.58 \mathrm{E}-04$ \\
\hline 20021107151406 & $2.55 \mathrm{E}-03$ & $1.91 \mathrm{E}-03$ & $1.74 \mathrm{E}-03$ & $8.65 \mathrm{E}-03$ & $2.64 \mathrm{E}-03$ \\
\hline 20031125201946 & $5.12 \mathrm{E}-04$ & $1.61 \mathrm{E}-04$ & $1.47 \mathrm{E}-04$ & $2.45 \mathrm{E}-03$ & $4.55 \mathrm{E}-04$ \\
\hline 20050116201752 & 4.10E-04 & $2.40 \mathrm{E}-04$ & $2.18 \mathrm{E}-04$ & $2.98 \mathrm{E}-03$ & $5.50 \mathrm{E}-04$ \\
\hline 20050205033425 & $6.15 \mathrm{E}-03$ & $1.86 \mathrm{E}-03$ & $1.69 \mathrm{E}-03$ & 7.09E-03 & $5.12 \mathrm{E}-03$ \\
\hline 20070130213744 & $2.38 \mathrm{E}-04$ & $3.51 \mathrm{E}-05$ & $3.19 \mathrm{E}-05$ & $1.34 \mathrm{E}-03$ & $1.44 \mathrm{E}-04$ \\
\hline 20071127114958 & $4.56 \mathrm{E}-03$ & $1.71 \mathrm{E}-03$ & $1.55 \mathrm{E}-03$ & $8.34 \mathrm{E}-03$ & $2.12 \mathrm{E}-03$ \\
\hline 20080719092701 & $7.20 \mathrm{E}-04$ & $2.38 \mathrm{E}-04$ & $2.16 \mathrm{E}-04$ & $3.02 \mathrm{E}-03$ & 4.92E-04 \\
\hline 20090830145132 & 7.42E-03 & $7.31 \mathrm{E}-03$ & $6.64 \mathrm{E}-03$ & $1.99 \mathrm{E}-02$ & $6.23 \mathrm{E}-03$ \\
\hline 20100103214805 & $2.42 \mathrm{E}-03$ & $1.96 \mathrm{E}-03$ & $1.78 \mathrm{E}-03$ & 8.89E-03 & $2.55 \mathrm{E}-03$ \\
\hline 20040125114311 & 4.63E-03 & $8.60 \mathrm{E}-04$ & $7.82 \mathrm{E}-04$ & 4.94E-03 & $2.99 \mathrm{E}-03$ \\
\hline 20050208144821 & 4.77E-04 & $3.01 \mathrm{E}-05$ & $2.73 \mathrm{E}-05$ & $1.12 \mathrm{E}-03$ & 2.61E-04 \\
\hline 20100626053019 & $3.86 \mathrm{E}-02$ & $5.51 \mathrm{E}-03$ & $5.01 \mathrm{E}-03$ & $1.61 \mathrm{E}-02$ & $5.93 \mathrm{E}-03$ \\
\hline 19960322032420 & $3.27 \mathrm{E}-03$ & $2.01 \mathrm{E}-03$ & $1.82 \mathrm{E}-03$ & $9.38 \mathrm{E}-03$ & $2.43 \mathrm{E}-03$ \\
\hline 20031210043811 & $3.45 \mathrm{E}-03$ & $6.36 \mathrm{E}-03$ & $5.79 \mathrm{E}-03$ & $1.83 \mathrm{E}-02$ & $5.39 \mathrm{E}-03$ \\
\hline 20041008082753 & $1.50 \mathrm{E}-02$ & $2.84 \mathrm{E}-03$ & $2.58 \mathrm{E}-03$ & $1.11 \mathrm{E}-02$ & $3.57 \mathrm{E}-03$ \\
\hline 20080509215129 & $9.61 \mathrm{E}-03$ & $6.10 \mathrm{E}-03$ & $5.54 \mathrm{E}-03$ & $1.60 \mathrm{E}-02$ & $8.70 \mathrm{E}-03$ \\
\hline 20081209062359 & $7.57 \mathrm{E}-03$ & $4.71 \mathrm{E}-03$ & $4.28 \mathrm{E}-03$ & $1.52 \mathrm{E}-02$ & $4.55 \mathrm{E}-03$ \\
\hline 20091124124715 & 7.92E-04 & $6.69 \mathrm{E}-05$ & $6.09 \mathrm{E}-05$ & $1.96 \mathrm{E}-03$ & $2.21 \mathrm{E}-04$ \\
\hline 20091124124716 & 7.92E-04 & $6.69 \mathrm{E}-05$ & $6.09 \mathrm{E}-05$ & $1.96 \mathrm{E}-03$ & $2.21 \mathrm{E}-04$ \\
\hline 20100105121532 & $1.20 \mathrm{E}-02$ & $3.58 \mathrm{E}-03$ & $3.25 \mathrm{E}-03$ & $1.31 \mathrm{E}-02$ & $3.61 \mathrm{E}-03$ \\
\hline 20100411094025 & $8.55 \mathrm{E}-03$ & $7.35 \mathrm{E}-03$ & $6.68 \mathrm{E}-03$ & $1.96 \mathrm{E}-02$ & $6.56 \mathrm{E}-03$ \\
\hline 20060928062209 & $3.08 \mathrm{E}-03$ & $3.40 \mathrm{E}-03$ & $3.09 \mathrm{E}-03$ & $1.26 \mathrm{E}-02$ & $3.81 \mathrm{E}-03$ \\
\hline 20061226123413 & $3.56 \mathrm{E}-03$ & 2.04E-03 & $1.85 \mathrm{E}-03$ & $9.78 \mathrm{E}-03$ & $2.26 \mathrm{E}-03$ \\
\hline 20070930020830 & 4.24E-03 & $1.85 \mathrm{E}-03$ & $1.68 \mathrm{E}-03$ & $9.23 \mathrm{E}-03$ & $2.17 \mathrm{E}-03$ \\
\hline 20080908185206 & $2.09 \mathrm{E}-03$ & 5.94E-05 & $5.40 \mathrm{E}-05$ & $1.82 \mathrm{E}-03$ & $4.31 \mathrm{E}-04$ \\
\hline 20100718130409 & $2.21 \mathrm{E}-03$ & $5.14 \mathrm{E}-04$ & 4.67E-04 & $4.80 \mathrm{E}-03$ & $9.68 \mathrm{E}-04$ \\
\hline 20011012150216 & $1.55 \mathrm{E}-01$ & $3.86 \mathrm{E}-02$ & $3.56 \mathrm{E}-02$ & $4.30 \mathrm{E}-02$ & $2.68 \mathrm{E}-02$ \\
\hline 20090218215345 & $1.42 \mathrm{E}-02$ & $6.63 \mathrm{E}-03$ & $6.03 \mathrm{E}-03$ & $1.85 \mathrm{E}-02$ & $6.12 \mathrm{E}-03$ \\
\hline 20020426160607 & $7.81 \mathrm{E}-02$ & 7.97E-02 & $7.24 \mathrm{E}-02$ & $6.68 \mathrm{E}-02$ & $7.08 \mathrm{E}-02$ \\
\hline 20030317163617 & $1.25 \mathrm{E}-03$ & $7.66 \mathrm{E}-03$ & $7.06 \mathrm{E}-03$ & 7.99E-03 & $4.63 \mathrm{E}-03$ \\
\hline 20100103223627 & $9.45 \mathrm{E}-03$ & $1.05 \mathrm{E}-02$ & $9.70 \mathrm{E}-03$ & $1.19 \mathrm{E}-02$ & $7.10 \mathrm{E}-03$ \\
\hline 20000108164720 & $1.41 \mathrm{E}-02$ & $2.67 \mathrm{E}-03$ & $2.42 \mathrm{E}-03$ & $9.29 \mathrm{E}-03$ & $5.95 \mathrm{E}-03$ \\
\hline 20071031033015 & $1.81 \mathrm{E}-03$ & 8.98E-04 & $8.17 \mathrm{E}-04$ & $5.52 \mathrm{E}-03$ & $2.64 \mathrm{E}-03$ \\
\hline 20071219093027 & $2.72 \mathrm{E}-02$ & $2.53 \mathrm{E}-02$ & $2.33 \mathrm{E}-02$ & $2.38 \mathrm{E}-02$ & $1.47 \mathrm{E}-02$ \\
\hline 19960610152456 & $8.74 \mathrm{E}-02$ & $9.19 \mathrm{E}-02$ & $8.46 \mathrm{E}-02$ & $9.62 \mathrm{E}-02$ & $7.74 \mathrm{E}-02$ \\
\hline 20100718133459 & $1.10 \mathrm{E}-03$ & $6.15 \mathrm{E}-03$ & $5.67 \mathrm{E}-03$ & $5.70 \mathrm{E}-03$ & $2.93 \mathrm{E}-03$ \\
\hline 20070928133857 & $1.01 \mathrm{E}-03$ & $2.29 \mathrm{E}-04$ & $2.08 \mathrm{E}-04$ & $3.74 \mathrm{E}-03$ & $9.75 \mathrm{E}-04$ \\
\hline
\end{tabular}


Table 3. 1-second spectral acceleration.-Continued

\begin{tabular}{cccccc}
\hline Earthquake origin time & Observed & AB-Cascadia & AB-Global & Geomatrix & $\begin{array}{c}\text { Zhao and others } \\
(\mathbf{2 0 0 6})\end{array}$ \\
\hline 20090319181740 & $1.71 \mathrm{E}-02$ & $6.17 \mathrm{E}-04$ & $5.61 \mathrm{E}-04$ & $7.14 \mathrm{E}-03$ & $1.18 \mathrm{E}-03$ \\
20091007220314 & $1.69 \mathrm{E}-03$ & $6.36 \mathrm{E}-03$ & $5.86 \mathrm{E}-03$ & $4.88 \mathrm{E}-03$ & $1.81 \mathrm{E}-03$ \\
20031117064306 & $5.41 \mathrm{E}-03$ & $2.68 \mathrm{E}-02$ & $2.44 \mathrm{E}-02$ & $4.03 \mathrm{E}-02$ & $1.83 \mathrm{E}-02$ \\
19960610040335 & $9.09 \mathrm{E}-02$ & $1.89 \mathrm{E}-01$ & $1.74 \mathrm{E}-01$ & $1.60 \mathrm{E}-01$ & $1.75 \mathrm{E}-01$ \\
20060503152640 & $8.89 \mathrm{E}-03$ & $2.35 \mathrm{E}-03$ & $2.14 \mathrm{E}-03$ & $1.40 \mathrm{E}-02$ & $3.74 \mathrm{E}-03$ \\
20070401203958 & $1.49 \mathrm{E}-02$ & $7.53 \mathrm{E}-02$ & $6.93 \mathrm{E}-02$ & $4.46 \mathrm{E}-02$ & $2.93 \mathrm{E}-02$ \\
20090929174810 & $8.63 \mathrm{E}-02$ & $2.74 \mathrm{E}-01$ & $2.49 \mathrm{E}-01$ & $1.44 \mathrm{E}-01$ & $1.36 \mathrm{E}-01$ \\
\hline
\end{tabular}


Table 4. 5-Hz spectral acceleration

\begin{tabular}{|c|c|c|c|c|c|}
\hline Earthquake origin time & Observed & AB-Cascadia & AB-Global & Geomatrix & $\begin{array}{c}\text { Zhao anc } \\
\text { others }\end{array}$ \\
\hline 19960819041916 & $3.59 \mathrm{E}-02$ & $9.68 \mathrm{E}-03$ & $1.26 \mathrm{E}-02$ & $4.10 \mathrm{E}-02$ & $2.24 \mathrm{E}-02$ \\
\hline 19990918212833 & 7.35E-03 & $3.52 \mathrm{E}-03$ & $4.59 \mathrm{E}-03$ & $1.41 \mathrm{E}-02$ & $8.58 \mathrm{E}-03$ \\
\hline 19991219004836 & $6.32 \mathrm{E}-02$ & $2.20 \mathrm{E}-02$ & $2.87 \mathrm{E}-02$ & $6.53 \mathrm{E}-02$ & 4.99E-02 \\
\hline 20010201181930 & $4.79 \mathrm{E}-02$ & $1.87 \mathrm{E}-02$ & $2.44 \mathrm{E}-02$ & $6.85 \mathrm{E}-02$ & 4.12E-02 \\
\hline 20021016141312 & $6.15 \mathrm{E}-03$ & $1.97 \mathrm{E}-03$ & $2.57 \mathrm{E}-03$ & $1.20 \mathrm{E}-02$ & $4.58 \mathrm{E}-03$ \\
\hline 20030610084030 & $1.54 \mathrm{E}-02$ & $6.00 \mathrm{E}-03$ & $7.83 \mathrm{E}-03$ & $2.51 \mathrm{E}-02$ & $1.44 \mathrm{E}-02$ \\
\hline 20040414013305 & $3.42 \mathrm{E}-03$ & $5.15 \mathrm{E}-04$ & $6.72 \mathrm{E}-04$ & $1.95 \mathrm{E}-03$ & 7.62E-04 \\
\hline 20060430193318 & $8.43 \mathrm{E}-04$ & $1.70 \mathrm{E}-03$ & $2.22 \mathrm{E}-03$ & $1.34 \mathrm{E}-02$ & $3.85 \mathrm{E}-03$ \\
\hline 20060707072612 & $1.56 \mathrm{E}-02$ & $1.85 \mathrm{E}-03$ & $2.42 \mathrm{E}-03$ & $1.12 \mathrm{E}-02$ & $4.31 \mathrm{E}-03$ \\
\hline 20080728214047 & $6.65 \mathrm{E}-04$ & 4.01E-04 & $5.23 \mathrm{E}-04$ & $4.84 \mathrm{E}-03$ & $8.08 \mathrm{E}-04$ \\
\hline 20090929175605 & $3.88 \mathrm{E}-03$ & $1.92 \mathrm{E}-03$ & $2.51 \mathrm{E}-03$ & $1.47 \mathrm{E}-02$ & $4.37 \mathrm{E}-03$ \\
\hline 20090929234503 & $2.37 \mathrm{E}-03$ & $1.70 \mathrm{E}-03$ & $2.21 \mathrm{E}-03$ & $1.34 \mathrm{E}-02$ & $3.84 \mathrm{E}-03$ \\
\hline 20091019224938 & $1.45 \mathrm{E}-02$ & $4.13 \mathrm{E}-03$ & $5.39 \mathrm{E}-03$ & $2.45 \mathrm{E}-02$ & $9.55 \mathrm{E}-03$ \\
\hline 20091128092117 & $7.65 \mathrm{E}-02$ & $1.86 \mathrm{E}-02$ & $2.43 \mathrm{E}-02$ & 7.18E-02 & 4.04E-02 \\
\hline 20100209010344 & $2.16 \mathrm{E}-03$ & $1.79 \mathrm{E}-03$ & $2.34 \mathrm{E}-03$ & $1.40 \mathrm{E}-02$ & $4.07 \mathrm{E}-03$ \\
\hline 20100804044620 & $2.02 \mathrm{E}-02$ & $1.21 \mathrm{E}-03$ & $1.58 \mathrm{E}-03$ & $9.67 \mathrm{E}-03$ & $2.71 \mathrm{E}-03$ \\
\hline 19980914231646 & $1.33 \mathrm{E}-03$ & $2.24 \mathrm{E}-03$ & $2.92 \mathrm{E}-03$ & $1.31 \mathrm{E}-02$ & $4.85 \mathrm{E}-03$ \\
\hline 20020128135028 & $7.75 \mathrm{E}-04$ & 2.97E-04 & $3.87 \mathrm{E}-04$ & $3.39 \mathrm{E}-03$ & $5.15 \mathrm{E}-04$ \\
\hline 20021126004815 & $6.06 \mathrm{E}-03$ & $2.53 \mathrm{E}-03$ & $3.30 \mathrm{E}-03$ & $1.62 \mathrm{E}-02$ & $5.44 \mathrm{E}-03$ \\
\hline 20050117105032 & $3.74 \mathrm{E}-04$ & $1.18 \mathrm{E}-04$ & $1.54 \mathrm{E}-04$ & $2.33 \mathrm{E}-03$ & $1.77 \mathrm{E}-04$ \\
\hline 20050604145046 & $5.40 \mathrm{E}-04$ & $7.15 \mathrm{E}-04$ & $9.33 \mathrm{E}-04$ & $6.26 \mathrm{E}-03$ & $1.41 \mathrm{E}-03$ \\
\hline 20060401100219 & $2.44 \mathrm{E}-03$ & $1.88 \mathrm{E}-03$ & $2.46 \mathrm{E}-03$ & $1.45 \mathrm{E}-02$ & $3.96 \mathrm{E}-03$ \\
\hline 20070402104917 & $4.25 \mathrm{E}-04$ & $2.58 \mathrm{E}-04$ & $3.37 \mathrm{E}-04$ & $3.09 \mathrm{E}-03$ & $4.38 \mathrm{E}-04$ \\
\hline 20070826123731 & $2.28 \mathrm{E}-03$ & $7.50 \mathrm{E}-04$ & $9.79 \mathrm{E}-04$ & $2.82 \mathrm{E}-03$ & $1.38 \mathrm{E}-03$ \\
\hline 20071006123849 & $1.64 \mathrm{E}-03$ & $7.16 \mathrm{E}-05$ & $9.35 \mathrm{E}-05$ & $1.69 \mathrm{E}-03$ & 9.62E-05 \\
\hline 20080819163013 & $1.53 \mathrm{E}-03$ & $2.06 \mathrm{E}-03$ & $2.69 \mathrm{E}-03$ & $1.57 \mathrm{E}-02$ & $4.35 \mathrm{E}-03$ \\
\hline 20081102134842 & $1.38 \mathrm{E}-02$ & $6.55 \mathrm{E}-03$ & $8.55 \mathrm{E}-03$ & $2.86 \mathrm{E}-02$ & $1.45 \mathrm{E}-02$ \\
\hline 20081121070534 & $2.93 \mathrm{E}-02$ & 3.07E-02 & 4.01E-02 & $4.10 \mathrm{E}-02$ & $7.56 \mathrm{E}-02$ \\
\hline 20090817101056 & $9.19 \mathrm{E}-04$ & $1.37 \mathrm{E}-03$ & $1.79 \mathrm{E}-03$ & $1.09 \mathrm{E}-02$ & $2.84 \mathrm{E}-03$ \\
\hline 20091002010739 & $1.03 \mathrm{E}-03$ & 7.07E-04 & $9.23 \mathrm{E}-04$ & 7.29E-03 & $1.39 \mathrm{E}-03$ \\
\hline 20091003173606 & $7.79 \mathrm{E}-03$ & $7.51 \mathrm{E}-03$ & $9.80 \mathrm{E}-03$ & $3.45 \mathrm{E}-02$ & $1.64 \mathrm{E}-02$ \\
\hline 20091128181020 & $2.26 \mathrm{E}-03$ & $3.65 \mathrm{E}-03$ & 4.77E-03 & $1.79 \mathrm{E}-02$ & $8.10 \mathrm{E}-03$ \\
\hline 20100213023428 & $2.00 \mathrm{E}-05$ & $1.14 \mathrm{E}-05$ & $1.49 \mathrm{E}-05$ & $7.58 \mathrm{E}-04$ & $9.89 \mathrm{E}-06$ \\
\hline 20100421172029 & $1.25 \mathrm{E}-02$ & $3.18 \mathrm{E}-03$ & $4.15 \mathrm{E}-03$ & $1.66 \mathrm{E}-02$ & $7.00 \mathrm{E}-03$ \\
\hline 20100624053227 & $3.36 \mathrm{E}-04$ & $9.46 \mathrm{E}-05$ & $1.24 \mathrm{E}-04$ & $1.70 \mathrm{E}-03$ & $1.31 \mathrm{E}-04$ \\
\hline 20101123090106 & 8.61E-04 & $5.59 \mathrm{E}-04$ & 7.30E-04 & $3.76 \mathrm{E}-03$ & $1.05 \mathrm{E}-03$ \\
\hline 19961203125656 & $3.90 \mathrm{E}-03$ & $2.59 \mathrm{E}-04$ & $3.38 \mathrm{E}-04$ & $3.25 \mathrm{E}-03$ & $3.99 \mathrm{E}-04$ \\
\hline 20000421043517 & $4.35 \mathrm{E}-02$ & $1.78 \mathrm{E}-02$ & $2.32 \mathrm{E}-02$ & $6.20 \mathrm{E}-02$ & $3.54 \mathrm{E}-02$ \\
\hline 20001219131147 & $1.06 \mathrm{E}-02$ & $4.51 \mathrm{E}-03$ & $5.89 \mathrm{E}-03$ & $2.18 \mathrm{E}-02$ & $9.33 \mathrm{E}-03$ \\
\hline
\end{tabular}


Table 4. 5-Hz spectral acceleration.-Continued

\begin{tabular}{|c|c|c|c|c|c|}
\hline Earthquake origin time & Observed & AB-Cascadia & AB-Global & Geomatrix & $\begin{array}{c}\text { Zhao anc } \\
\text { others }\end{array}$ \\
\hline 20011002004818 & $3.65 \mathrm{E}-03$ & $2.41 \mathrm{E}-03$ & $3.14 \mathrm{E}-03$ & $7.05 \mathrm{E}-03$ & $4.96 \mathrm{E}-03$ \\
\hline 20030317185547 & $1.31 \mathrm{E}-03$ & $7.30 \mathrm{E}-04$ & $9.53 \mathrm{E}-04$ & $6.07 \mathrm{E}-03$ & $1.32 \mathrm{E}-03$ \\
\hline 20030328173147 & $2.01 \mathrm{E}-02$ & $2.98 \mathrm{E}-03$ & $3.89 \mathrm{E}-03$ & $1.48 \mathrm{E}-02$ & $6.12 \mathrm{E}-03$ \\
\hline 20030503050303 & $1.07 \mathrm{E}-02$ & $2.45 \mathrm{E}-03$ & $3.20 \mathrm{E}-03$ & $1.39 \mathrm{E}-02$ & $4.94 \mathrm{E}-03$ \\
\hline 20031007045528 & 7.03E-03 & 7.67E-04 & $1.00 \mathrm{E}-03$ & $7.65 \mathrm{E}-03$ & $1.40 \mathrm{E}-03$ \\
\hline 20040519070411 & $2.25 \mathrm{E}-03$ & $2.01 \mathrm{E}-03$ & $2.63 \mathrm{E}-03$ & $1.36 \mathrm{E}-02$ & $3.98 \mathrm{E}-03$ \\
\hline 20040903190447 & $2.48 \mathrm{E}-03$ & $2.58 \mathrm{E}-03$ & $3.37 \mathrm{E}-03$ & $1.80 \mathrm{E}-02$ & $5.12 \mathrm{E}-03$ \\
\hline 20050518102706 & $2.98 \mathrm{E}-03$ & $2.66 \mathrm{E}-03$ & $3.48 \mathrm{E}-03$ & $1.84 \mathrm{E}-02$ & $5.30 \mathrm{E}-03$ \\
\hline 20070402120223 & $7.21 \mathrm{E}-03$ & $1.66 \mathrm{E}-03$ & $2.16 \mathrm{E}-03$ & $1.26 \mathrm{E}-02$ & $3.23 \mathrm{E}-03$ \\
\hline 20070402232023 & $3.32 \mathrm{E}-03$ & $1.31 \mathrm{E}-03$ & $1.71 \mathrm{E}-03$ & $1.02 \mathrm{E}-02$ & $2.50 \mathrm{E}-03$ \\
\hline 20070906175126 & $2.39 \mathrm{E}-02$ & $2.35 \mathrm{E}-02$ & $3.06 \mathrm{E}-02$ & $6.27 \mathrm{E}-02$ & $4.82 \mathrm{E}-02$ \\
\hline 20080603162050 & $2.15 \mathrm{E}-02$ & $8.78 \mathrm{E}-03$ & $1.15 \mathrm{E}-02$ & $2.17 \mathrm{E}-02$ & $1.95 \mathrm{E}-02$ \\
\hline 20100109055130 & $4.57 \mathrm{E}-03$ & $1.83 \mathrm{E}-03$ & $2.39 \mathrm{E}-03$ & $1.38 \mathrm{E}-02$ & $3.59 \mathrm{E}-03$ \\
\hline 19950116181449 & $1.88 \mathrm{E}-03$ & $1.91 \mathrm{E}-03$ & $2.49 \mathrm{E}-03$ & $1.16 \mathrm{E}-02$ & $3.51 \mathrm{E}-03$ \\
\hline 20000126132650 & $1.69 \mathrm{E}-03$ & 4.88E-04 & $6.38 \mathrm{E}-04$ & $4.82 \mathrm{E}-03$ & 7.61E-04 \\
\hline 20010802234106 & $2.38 \mathrm{E}-04$ & $2.65 \mathrm{E}-04$ & $3.46 \mathrm{E}-04$ & $3.90 \mathrm{E}-03$ & $3.78 \mathrm{E}-04$ \\
\hline 20031022114530 & $5.20 \mathrm{E}-04$ & $1.08 \mathrm{E}-03$ & $1.41 \mathrm{E}-03$ & $6.68 \mathrm{E}-03$ & $1.86 \mathrm{E}-03$ \\
\hline 20040109223531 & $3.49 \mathrm{E}-04$ & $6.39 \mathrm{E}-04$ & $8.34 \mathrm{E}-04$ & 4.69E-03 & $1.02 \mathrm{E}-03$ \\
\hline 20050202023025 & 7.37E-02 & 4.53E-02 & $5.92 \mathrm{E}-02$ & $3.53 \mathrm{E}-02$ & $6.53 \mathrm{E}-02$ \\
\hline 20060214152723 & $7.81 \mathrm{E}-04$ & $3.57 \mathrm{E}-05$ & $4.67 \mathrm{E}-05$ & $1.20 \mathrm{E}-03$ & $3.15 \mathrm{E}-05$ \\
\hline 20100207061000 & $5.48 \mathrm{E}-03$ & $2.06 \mathrm{E}-03$ & $2.69 \mathrm{E}-03$ & $1.37 \mathrm{E}-02$ & $3.79 \mathrm{E}-03$ \\
\hline 20100304001851 & $3.19 \mathrm{E}-03$ & $3.02 \mathrm{E}-03$ & $3.95 \mathrm{E}-03$ & $1.80 \mathrm{E}-02$ & $5.70 \mathrm{E}-03$ \\
\hline 20100710114332 & $1.02 \mathrm{E}-02$ & $1.42 \mathrm{E}-03$ & $1.86 \mathrm{E}-03$ & $1.14 \mathrm{E}-02$ & $2.54 \mathrm{E}-03$ \\
\hline 20101004132838 & 7.49E-04 & $8.22 \mathrm{E}-04$ & $1.07 \mathrm{E}-03$ & $6.71 \mathrm{E}-03$ & $1.38 \mathrm{E}-03$ \\
\hline 19991207212949 & $8.85 \mathrm{E}-03$ & $5.17 \mathrm{E}-03$ & $6.75 \mathrm{E}-03$ & $9.12 \mathrm{E}-03$ & $8.28 \mathrm{E}-03$ \\
\hline 20030314125412 & $2.62 \mathrm{E}-03$ & 4.17E-03 & $5.44 \mathrm{E}-03$ & $2.80 \mathrm{E}-03$ & $7.83 \mathrm{E}-04$ \\
\hline 20030902182800 & $1.69 \mathrm{E}-02$ & $4.31 \mathrm{E}-03$ & $5.63 \mathrm{E}-03$ & $2.57 \mathrm{E}-02$ & $7.63 \mathrm{E}-03$ \\
\hline 20050122203017 & $2.17 \mathrm{E}-02$ & $6.66 \mathrm{E}-03$ & $8.69 \mathrm{E}-03$ & $2.94 \mathrm{E}-02$ & $1.22 \mathrm{E}-02$ \\
\hline 20051015155108 & $3.64 \mathrm{E}-03$ & $2.38 \mathrm{E}-02$ & $3.11 \mathrm{E}-02$ & $1.57 \mathrm{E}-02$ & $2.00 \mathrm{E}-02$ \\
\hline 20070404063435 & $1.22 \mathrm{E}-03$ & $5.70 \mathrm{E}-04$ & $7.45 \mathrm{E}-04$ & $6.16 \mathrm{E}-03$ & $8.42 \mathrm{E}-04$ \\
\hline 20090118141148 & $2.02 \mathrm{E}-01$ & $2.95 \mathrm{E}-02$ & $3.85 \mathrm{E}-02$ & $8.55 \mathrm{E}-02$ & 5.19E-02 \\
\hline 20091219130217 & 4.07E-02 & $2.23 \mathrm{E}-02$ & $2.92 \mathrm{E}-02$ & $5.50 \mathrm{E}-02$ & $4.21 \mathrm{E}-02$ \\
\hline 19960608231915 & 7.19E-02 & $3.40 \mathrm{E}-02$ & 4.44E-02 & $9.21 \mathrm{E}-02$ & $5.69 \mathrm{E}-02$ \\
\hline 20010703131042 & $2.77 \mathrm{E}-04$ & $5.59 \mathrm{E}-04$ & 7.30E-04 & $1.09 \mathrm{E}-03$ & $4.36 \mathrm{E}-05$ \\
\hline 20020814135752 & $3.63 \mathrm{E}-02$ & $1.42 \mathrm{E}-02$ & $1.86 \mathrm{E}-02$ & $5.01 \mathrm{E}-02$ & $2.46 \mathrm{E}-02$ \\
\hline 20070816083928 & $4.51 \mathrm{E}-01$ & $6.77 \mathrm{E}-02$ & $8.84 \mathrm{E}-02$ & $1.75 \mathrm{E}-01$ & $1.01 \mathrm{E}-01$ \\
\hline 20090516005351 & $2.25 \mathrm{E}-02$ & $4.05 \mathrm{E}-03$ & $5.29 \mathrm{E}-03$ & $1.79 \mathrm{E}-02$ & $6.90 \mathrm{E}-03$ \\
\hline 20100426025951 & $5.03 \mathrm{E}-03$ & $9.56 \mathrm{E}-04$ & $1.25 \mathrm{E}-03$ & $8.85 \mathrm{E}-03$ & $1.40 \mathrm{E}-03$ \\
\hline
\end{tabular}


Table 4. 5-Hz spectral acceleration.-Continued

\begin{tabular}{|c|c|c|c|c|c|}
\hline Earthquake origin time & Observed & AB-Cascadia & AB-Global & Geomatrix & $\begin{array}{c}\text { Zhao and } \\
\text { others }\end{array}$ \\
\hline 19971217043851 & $3.25 \mathrm{E}-03$ & $2.31 \mathrm{E}-03$ & $3.02 \mathrm{E}-03$ & $1.50 \mathrm{E}-02$ & $3.48 \mathrm{E}-03$ \\
\hline 19990128081005 & $3.90 \mathrm{E}-03$ & $6.88 \mathrm{E}-04$ & $8.98 \mathrm{E}-04$ & $4.95 \mathrm{E}-03$ & $8.49 \mathrm{E}-04$ \\
\hline 20021107151406 & $3.72 \mathrm{E}-03$ & $3.71 \mathrm{E}-03$ & $4.85 \mathrm{E}-03$ & $1.84 \mathrm{E}-02$ & $5.86 \mathrm{E}-03$ \\
\hline 20031125201946 & $5.62 \mathrm{E}-04$ & $2.80 \mathrm{E}-04$ & $3.66 \mathrm{E}-04$ & $3.84 \mathrm{E}-03$ & $2.99 \mathrm{E}-04$ \\
\hline 20050116201752 & $1.14 \mathrm{E}-03$ & $3.82 \mathrm{E}-04$ & 4.99E-04 & $4.89 \mathrm{E}-03$ & $4.42 \mathrm{E}-04$ \\
\hline 20050205033425 & $3.47 \mathrm{E}-02$ & $1.08 \mathrm{E}-02$ & $1.41 \mathrm{E}-02$ & $1.44 \mathrm{E}-02$ & $1.51 \mathrm{E}-02$ \\
\hline 20070130213744 & $2.79 \mathrm{E}-04$ & 4.73E-05 & $6.17 \mathrm{E}-05$ & $1.81 \mathrm{E}-03$ & 3.39E-05 \\
\hline 20071127114958 & $3.88 \mathrm{E}-03$ & $2.78 \mathrm{E}-03$ & $3.62 \mathrm{E}-03$ & $1.76 \mathrm{E}-02$ & $4.25 \mathrm{E}-03$ \\
\hline 20080719092701 & $1.02 \mathrm{E}-03$ & $3.32 \mathrm{E}-04$ & 4.34E-04 & $4.98 \mathrm{E}-03$ & $3.79 \mathrm{E}-04$ \\
\hline 20090830145132 & $1.57 \mathrm{E}-02$ & $1.19 \mathrm{E}-02$ & $1.56 \mathrm{E}-02$ & $5.18 \mathrm{E}-02$ & $1.92 \mathrm{E}-02$ \\
\hline 20100103214805 & $2.26 \mathrm{E}-03$ & $3.55 \mathrm{E}-03$ & 4.64E-03 & $1.90 \mathrm{E}-02$ & $5.58 \mathrm{E}-03$ \\
\hline 20040125114311 & $1.16 \mathrm{E}-02$ & $3.98 \mathrm{E}-03$ & $5.20 \mathrm{E}-03$ & $8.69 \mathrm{E}-03$ & $5.51 \mathrm{E}-03$ \\
\hline 20050208144821 & $8.75 \mathrm{E}-04$ & $2.40 \mathrm{E}-04$ & $3.14 \mathrm{E}-04$ & $1.38 \mathrm{E}-03$ & 4.94E-05 \\
\hline 20100626053019 & $7.26 \mathrm{E}-02$ & $1.08 \mathrm{E}-02$ & $1.41 \mathrm{E}-02$ & 3.77E-02 & $1.71 \mathrm{E}-02$ \\
\hline 19960322032420 & $2.35 \mathrm{E}-03$ & $3.08 \mathrm{E}-03$ & $4.02 \mathrm{E}-03$ & $1.83 \mathrm{E}-02$ & $4.21 \mathrm{E}-03$ \\
\hline 20031210043811 & $6.47 \mathrm{E}-03$ & $9.27 \mathrm{E}-03$ & $1.21 \mathrm{E}-02$ & $4.21 \mathrm{E}-02$ & $1.36 \mathrm{E}-02$ \\
\hline 20041008082753 & $1.40 \mathrm{E}-02$ & $5.20 \mathrm{E}-03$ & $6.79 \mathrm{E}-03$ & $2.25 \mathrm{E}-02$ & 7.49E-03 \\
\hline 20080509215129 & $2.03 \mathrm{E}-02$ & $1.72 \mathrm{E}-02$ & $2.25 \mathrm{E}-02$ & $3.54 \mathrm{E}-02$ & $2.75 \mathrm{E}-02$ \\
\hline 20081209062359 & $8.06 \mathrm{E}-02$ & $7.35 \mathrm{E}-03$ & $9.59 \mathrm{E}-03$ & $3.33 \mathrm{E}-02$ & $1.07 \mathrm{E}-02$ \\
\hline 20091124124715 & $9.41 \mathrm{E}-04$ & $8.21 \mathrm{E}-05$ & $1.07 \mathrm{E}-04$ & $2.61 \mathrm{E}-03$ & $5.63 \mathrm{E}-05$ \\
\hline 20091124124716 & $9.41 \mathrm{E}-04$ & $8.21 \mathrm{E}-05$ & $1.07 \mathrm{E}-04$ & $2.61 \mathrm{E}-03$ & 5.63E-05 \\
\hline 20100105121532 & $1.38 \mathrm{E}-02$ & $5.36 \mathrm{E}-03$ & $6.99 \mathrm{E}-03$ & $2.76 \mathrm{E}-02$ & $7.66 \mathrm{E}-03$ \\
\hline 20100411094025 & $5.17 \mathrm{E}-02$ & $1.20 \mathrm{E}-02$ & $1.57 \mathrm{E}-02$ & $4.56 \mathrm{E}-02$ & $1.79 \mathrm{E}-02$ \\
\hline 20060928062209 & $1.46 \mathrm{E}-02$ & $5.50 \mathrm{E}-03$ & $7.18 \mathrm{E}-03$ & $2.50 \mathrm{E}-02$ & $7.51 \mathrm{E}-03$ \\
\hline 20061226123413 & 4.77E-03 & $2.68 \mathrm{E}-03$ & $3.50 \mathrm{E}-03$ & $1.83 \mathrm{E}-02$ & $3.40 \mathrm{E}-03$ \\
\hline 20070930020830 & $1.40 \mathrm{E}-02$ & $2.52 \mathrm{E}-03$ & $3.29 \mathrm{E}-03$ & $1.70 \mathrm{E}-02$ & $3.17 \mathrm{E}-03$ \\
\hline 20080908185206 & $2.22 \mathrm{E}-03$ & $1.70 \mathrm{E}-04$ & $2.22 \mathrm{E}-04$ & $2.26 \mathrm{E}-03$ & $1.07 \mathrm{E}-04$ \\
\hline 20100718130409 & $2.52 \mathrm{E}-03$ & $7.51 \mathrm{E}-04$ & $9.81 \mathrm{E}-04$ & $7.55 \mathrm{E}-03$ & $7.73 \mathrm{E}-04$ \\
\hline 20011012150216 & 4.01E-01 & $7.80 \mathrm{E}-02$ & $1.03 \mathrm{E}-01$ & $1.20 \mathrm{E}-01$ & $9.22 \mathrm{E}-02$ \\
\hline 20090218215345 & $1.00 \mathrm{E}-01$ & $1.02 \mathrm{E}-02$ & $1.33 \mathrm{E}-02$ & $3.83 \mathrm{E}-02$ & $1.38 \mathrm{E}-02$ \\
\hline 20020426160607 & $2.66 \mathrm{E}-01$ & $2.29 \mathrm{E}-01$ & $2.83 \mathrm{E}-01$ & $1.80 \mathrm{E}-01$ & $3.29 \mathrm{E}-01$ \\
\hline 20030317163617 & $1.46 \mathrm{E}-03$ & $5.33 \mathrm{E}-03$ & $8.54 \mathrm{E}-03$ & $1.41 \mathrm{E}-02$ & $5.17 \mathrm{E}-03$ \\
\hline 20100103223627 & $3.31 \mathrm{E}-03$ & $9.40 \mathrm{E}-03$ & $1.45 \mathrm{E}-02$ & $2.31 \mathrm{E}-02$ & $1.12 \mathrm{E}-02$ \\
\hline 20000108164720 & $2.09 \mathrm{E}-02$ & $1.71 \mathrm{E}-02$ & $2.23 \mathrm{E}-02$ & $1.48 \mathrm{E}-02$ & $9.38 \mathrm{E}-03$ \\
\hline 20071031033015 & $9.53 \mathrm{E}-03$ & $6.85 \mathrm{E}-03$ & $8.95 \mathrm{E}-03$ & $7.76 \mathrm{E}-03$ & $2.15 \mathrm{E}-03$ \\
\hline 20071219093027 & 4.91E-02 & $3.46 \mathrm{E}-02$ & $4.93 \mathrm{E}-02$ & $5.21 \mathrm{E}-02$ & $3.32 \mathrm{E}-02$ \\
\hline 19960610152456 & 7.76E-01 & $1.93 \mathrm{E}-01$ & $2.58 \mathrm{E}-01$ & $2.82 \mathrm{E}-01$ & $2.68 \mathrm{E}-01$ \\
\hline 20100718133459 & $1.27 \mathrm{E}-03$ & $2.30 \mathrm{E}-03$ & $4.13 \mathrm{E}-03$ & $8.42 \mathrm{E}-03$ & $1.54 \mathrm{E}-03$ \\
\hline 20070928133857 & $6.80 \mathrm{E}-04$ & $2.25 \mathrm{E}-03$ & $2.94 \mathrm{E}-03$ & $4.15 \mathrm{E}-03$ & $1.76 \mathrm{E}-04$ \\
\hline
\end{tabular}


Table 4. 5-Hz spectral acceleration.-Continued

\begin{tabular}{cccccc}
\hline Earthquake origin time & Observed & AB-Cascadia & AB-Global & Geomatrix & $\begin{array}{c}\text { Zhao and } \\
\text { others }\end{array}$ \\
\hline 20090319181740 & $4.61 \mathrm{E}-02$ & $6.28 \mathrm{E}-04$ & $8.21 \mathrm{E}-04$ & $8.87 \mathrm{E}-03$ & $3.84 \mathrm{E}-04$ \\
20091007220314 & $2.23 \mathrm{E}-03$ & $8.99 \mathrm{E}-04$ & $1.92 \mathrm{E}-03$ & $5.79 \mathrm{E}-03$ & $2.73 \mathrm{E}-04$ \\
20031117064306 & $6.28 \mathrm{E}-03$ & $3.10 \mathrm{E}-02$ & $4.05 \mathrm{E}-02$ & $6.98 \mathrm{E}-02$ & $3.65 \mathrm{E}-02$ \\
\hline 19960610040335 & $3.80 \mathrm{E}-01$ & $3.80 \mathrm{E}-01$ & $4.95 \mathrm{E}-01$ & $4.05 \mathrm{E}-01$ & $4.88 \mathrm{E}-01$ \\
20060503152640 & $1.11 \mathrm{E}-02$ & $2.63 \mathrm{E}-03$ & $3.44 \mathrm{E}-03$ & $1.72 \mathrm{E}-02$ & $1.81 \mathrm{E}-03$ \\
\hline 20070401203958 & $8.70 \mathrm{E}-03$ & $6.91 \mathrm{E}-02$ & $1.10 \mathrm{E}-01$ & $7.64 \mathrm{E}-02$ & $4.14 \mathrm{E}-02$ \\
\hline 20090929174810 & $1.02 \mathrm{E}-01$ & $2.67 \mathrm{E}-01$ & $3.49 \mathrm{E}-01$ & $3.12 \mathrm{E}-01$ & $4.35 \mathrm{E}-01$ \\
\hline
\end{tabular}


Table 5. Peak horizontal ground acceleration.

\begin{tabular}{|c|c|c|c|c|c|}
\hline Earthquake origin time & Observed & AB-Cascadia & AB-Global & Geomatrix & $\begin{array}{l}\text { Zhao and } \\
\text { others (2006) }\end{array}$ \\
\hline 19960819041916 & $1.17 \mathrm{E}-02$ & $3.48 \mathrm{E}-03$ & $5.55 \mathrm{E}-03$ & $2.01 \mathrm{E}-02$ & $1.06 \mathrm{E}-02$ \\
\hline 19990918212833 & $2.54 \mathrm{E}-03$ & $1.75 \mathrm{E}-03$ & $2.79 \mathrm{E}-03$ & 7.10E-03 & $4.00 \mathrm{E}-03$ \\
\hline 19991219004836 & $2.40 \mathrm{E}-02$ & $9.90 \mathrm{E}-03$ & $1.58 \mathrm{E}-02$ & $3.17 \mathrm{E}-02$ & $2.38 \mathrm{E}-02$ \\
\hline 20010201181930 & $1.52 \mathrm{E}-02$ & $6.77 \mathrm{E}-03$ & $1.08 \mathrm{E}-02$ & $3.33 \mathrm{E}-02$ & $1.99 \mathrm{E}-02$ \\
\hline 20021016141312 & 4.49E-03 & $6.90 \mathrm{E}-04$ & $1.10 \mathrm{E}-03$ & $6.02 \mathrm{E}-03$ & $2.18 \mathrm{E}-03$ \\
\hline 20030610084030 & $5.97 \mathrm{E}-03$ & $2.46 \mathrm{E}-03$ & $3.93 \mathrm{E}-03$ & $1.24 \mathrm{E}-02$ & $6.73 \mathrm{E}-03$ \\
\hline 20040414013305 & $1.58 \mathrm{E}-03$ & $6.90 \mathrm{E}-04$ & $1.10 \mathrm{E}-03$ & $1.02 \mathrm{E}-03$ & $4.04 \mathrm{E}-04$ \\
\hline 20060430193318 & $5.34 \mathrm{E}-04$ & 4.44E-04 & 7.09E-04 & $6.75 \mathrm{E}-03$ & $1.84 \mathrm{E}-03$ \\
\hline 20060707072612 & $1.08 \mathrm{E}-02$ & $6.65 \mathrm{E}-04$ & $1.06 \mathrm{E}-03$ & $5.66 \mathrm{E}-03$ & $2.05 \mathrm{E}-03$ \\
\hline 20080728214047 & $2.50 \mathrm{E}-04$ & $1.01 \mathrm{E}-04$ & $1.62 \mathrm{E}-04$ & $2.49 \mathrm{E}-03$ & 4.08E-04 \\
\hline 20090929175605 & $3.15 \mathrm{E}-03$ & $5.03 \mathrm{E}-04$ & $8.03 \mathrm{E}-04$ & $7.38 \mathrm{E}-03$ & 2.09E-03 \\
\hline 20090929234503 & $1.69 \mathrm{E}-03$ & 4.43E-04 & 7.07E-04 & $6.74 \mathrm{E}-03$ & $1.84 \mathrm{E}-03$ \\
\hline 20091019224938 & $6.40 \mathrm{E}-03$ & $1.21 \mathrm{E}-03$ & $1.94 \mathrm{E}-03$ & $1.22 \mathrm{E}-02$ & $4.53 \mathrm{E}-03$ \\
\hline 20091128092117 & $2.98 \mathrm{E}-02$ & $6.33 \mathrm{E}-03$ & $1.01 \mathrm{E}-02$ & $3.48 \mathrm{E}-02$ & $1.96 \mathrm{E}-02$ \\
\hline 20100209010344 & $1.58 \mathrm{E}-03$ & 4.69E-04 & 7.49E-04 & $7.02 \mathrm{E}-03$ & $1.95 \mathrm{E}-03$ \\
\hline 20100804044620 & $6.29 \mathrm{E}-03$ & $3.48 \mathrm{E}-04$ & $5.55 \mathrm{E}-04$ & 4.89E-03 & $1.31 \mathrm{E}-03$ \\
\hline 19980914231646 & 4.41E-04 & $7.83 \mathrm{E}-04$ & $1.25 \mathrm{E}-03$ & $6.52 \mathrm{E}-03$ & $2.29 \mathrm{E}-03$ \\
\hline 20020128135028 & $3.58 \mathrm{E}-04$ & $9.88 \mathrm{E}-05$ & $1.58 \mathrm{E}-04$ & $1.74 \mathrm{E}-03$ & $2.70 \mathrm{E}-04$ \\
\hline 20021126004815 & $1.51 \mathrm{E}-03$ & $7.53 \mathrm{E}-04$ & $1.20 \mathrm{E}-03$ & 8.07E-03 & $2.58 \mathrm{E}-03$ \\
\hline 20050117105032 & $1.53 \mathrm{E}-04$ & $2.94 \mathrm{E}-05$ & 4.69E-05 & $1.21 \mathrm{E}-03$ & $9.84 \mathrm{E}-05$ \\
\hline 20050604145046 & $3.50 \mathrm{E}-04$ & $2.23 \mathrm{E}-04$ & $3.56 \mathrm{E}-04$ & $3.18 \mathrm{E}-03$ & $6.95 \mathrm{E}-04$ \\
\hline 20060401100219 & $2.14 \mathrm{E}-03$ & $4.85 \mathrm{E}-04$ & $7.74 \mathrm{E}-04$ & $7.23 \mathrm{E}-03$ & $1.89 \mathrm{E}-03$ \\
\hline 20070402104917 & $1.71 \mathrm{E}-04$ & $8.67 \mathrm{E}-05$ & $1.38 \mathrm{E}-04$ & $1.59 \mathrm{E}-03$ & $2.31 \mathrm{E}-04$ \\
\hline 20070826123731 & $1.42 \mathrm{E}-03$ & $8.28 \mathrm{E}-04$ & $1.32 \mathrm{E}-03$ & $1.46 \mathrm{E}-03$ & 7.03E-04 \\
\hline 20071006123849 & $6.50 \mathrm{E}-04$ & $1.94 \mathrm{E}-05$ & $3.10 \mathrm{E}-05$ & 8.82E-04 & $5.63 \mathrm{E}-05$ \\
\hline 20080819163013 & 8.89E-04 & $5.26 \mathrm{E}-04$ & 8.39E-04 & $7.80 \mathrm{E}-03$ & $2.08 \mathrm{E}-03$ \\
\hline 20081102134842 & $3.48 \mathrm{E}-03$ & $2.43 \mathrm{E}-03$ & $3.87 \mathrm{E}-03$ & $1.40 \mathrm{E}-02$ & $6.79 \mathrm{E}-03$ \\
\hline 20081121070534 & $9.89 \mathrm{E}-03$ & $3.28 \mathrm{E}-02$ & $5.24 \mathrm{E}-02$ & $2.00 \mathrm{E}-02$ & $3.41 \mathrm{E}-02$ \\
\hline 20090817101056 & $3.58 \mathrm{E}-04$ & $3.78 \mathrm{E}-04$ & $6.03 \mathrm{E}-04$ & $5.44 \mathrm{E}-03$ & $1.37 \mathrm{E}-03$ \\
\hline 20091002010739 & $5.51 \mathrm{E}-04$ & $1.76 \mathrm{E}-04$ & $2.81 \mathrm{E}-04$ & $3.69 \mathrm{E}-03$ & $6.84 \mathrm{E}-04$ \\
\hline 20091003173606 & $3.34 \mathrm{E}-03$ & $2.52 \mathrm{E}-03$ & 4.02E-03 & $1.69 \mathrm{E}-02$ & $7.70 \mathrm{E}-03$ \\
\hline 20091128181020 & $9.29 \mathrm{E}-04$ & $1.37 \mathrm{E}-03$ & 2.19E-03 & 8.89E-03 & $3.80 \mathrm{E}-03$ \\
\hline 20100213023428 & $1.30 \mathrm{E}-05$ & $2.60 \mathrm{E}-06$ & 4.14E-06 & $4.02 \mathrm{E}-04$ & $7.00 \mathrm{E}-06$ \\
\hline 20100421172029 & $9.68 \mathrm{E}-03$ & $1.15 \mathrm{E}-03$ & $1.83 \mathrm{E}-03$ & $8.26 \mathrm{E}-03$ & $3.29 \mathrm{E}-03$ \\
\hline 20100624053227 & $1.65 \mathrm{E}-04$ & $3.32 \mathrm{E}-05$ & $5.30 \mathrm{E}-05$ & 8.89E-04 & $7.60 \mathrm{E}-05$ \\
\hline 20101123090106 & $3.01 \mathrm{E}-04$ & $2.94 \mathrm{E}-04$ & $4.68 \mathrm{E}-04$ & $1.93 \mathrm{E}-03$ & $5.33 \mathrm{E}-04$ \\
\hline 19961203125656 & 2.79E-03 & $8.45 \mathrm{E}-05$ & $1.35 \mathrm{E}-04$ & $1.66 \mathrm{E}-03$ & $2.13 \mathrm{E}-04$ \\
\hline 20000421043517 & $1.11 \mathrm{E}-02$ & $6.40 \mathrm{E}-03$ & $1.02 \mathrm{E}-02$ & $2.97 \mathrm{E}-02$ & $1.68 \mathrm{E}-02$ \\
\hline 20001219131147 & $3.83 \mathrm{E}-03$ & $1.59 \mathrm{E}-03$ & $2.54 \mathrm{E}-03$ & $1.07 \mathrm{E}-02$ & $4.36 \mathrm{E}-03$ \\
\hline
\end{tabular}


Table 5. Peak horizontal ground acceleration.-Continued

\begin{tabular}{|c|c|c|c|c|c|}
\hline Earthquake origin time & Observed & AB-Cascadia & AB-Global & Geomatrix & $\begin{array}{c}\text { Zhao and } \\
\text { others (2006) }\end{array}$ \\
\hline 20011002004818 & $3.85 \mathrm{E}-03$ & $2.10 \mathrm{E}-03$ & $3.35 \mathrm{E}-03$ & $3.54 \mathrm{E}-03$ & $2.35 \mathrm{E}-03$ \\
\hline 20030317185547 & $5.90 \mathrm{E}-04$ & $2.48 \mathrm{E}-04$ & $3.96 \mathrm{E}-04$ & $3.06 \mathrm{E}-03$ & $6.55 \mathrm{E}-04$ \\
\hline 20030328173147 & $1.29 \mathrm{E}-02$ & $1.16 \mathrm{E}-03$ & $1.84 \mathrm{E}-03$ & 7.34E-03 & $2.87 \mathrm{E}-03$ \\
\hline 20030503050303 & $7.85 \mathrm{E}-03$ & $8.55 \mathrm{E}-04$ & $1.36 \mathrm{E}-03$ & $6.88 \mathrm{E}-03$ & $2.34 \mathrm{E}-03$ \\
\hline 20031007045528 & $4.52 \mathrm{E}-03$ & $1.96 \mathrm{E}-04$ & $3.12 \mathrm{E}-04$ & $3.83 \mathrm{E}-03$ & $6.89 \mathrm{E}-04$ \\
\hline 20040519070411 & $8.65 \mathrm{E}-04$ & $5.94 \mathrm{E}-04$ & $9.47 \mathrm{E}-04$ & $6.75 \mathrm{E}-03$ & $1.89 \mathrm{E}-03$ \\
\hline 20040903190447 & $1.59 \mathrm{E}-03$ & $6.74 \mathrm{E}-04$ & $1.08 \mathrm{E}-03$ & $8.86 \mathrm{E}-03$ & $2.43 \mathrm{E}-03$ \\
\hline 20050518102706 & $1.59 \mathrm{E}-03$ & $6.97 \mathrm{E}-04$ & $1.11 \mathrm{E}-03$ & $9.08 \mathrm{E}-03$ & $2.51 \mathrm{E}-03$ \\
\hline 20070402120223 & $2.23 \mathrm{E}-03$ & 4.52E-04 & $7.21 \mathrm{E}-04$ & $6.23 \mathrm{E}-03$ & $1.55 \mathrm{E}-03$ \\
\hline 20070402232023 & $1.28 \mathrm{E}-03$ & $3.73 \mathrm{E}-04$ & $5.95 \mathrm{E}-04$ & $5.10 \mathrm{E}-03$ & $1.21 \mathrm{E}-03$ \\
\hline 20070906175126 & $1.04 \mathrm{E}-02$ & 1.09E-02 & $1.74 \mathrm{E}-02$ & $3.01 \mathrm{E}-02$ & $2.26 \mathrm{E}-02$ \\
\hline 20080603162050 & $7.32 \mathrm{E}-03$ & $5.97 \mathrm{E}-03$ & $9.52 \mathrm{E}-03$ & $1.06 \mathrm{E}-02$ & $8.90 \mathrm{E}-03$ \\
\hline 20100109055130 & $1.37 \mathrm{E}-03$ & 4.88E-04 & 7.79E-04 & $6.81 \mathrm{E}-03$ & $1.71 \mathrm{E}-03$ \\
\hline 19950116181449 & $6.42 \mathrm{E}-04$ & $6.60 \mathrm{E}-04$ & $1.05 \mathrm{E}-03$ & $5.75 \mathrm{E}-03$ & $1.67 \mathrm{E}-03$ \\
\hline 20000126132650 & $1.15 \mathrm{E}-03$ & $1.63 \mathrm{E}-04$ & $2.60 \mathrm{E}-04$ & $2.43 \mathrm{E}-03$ & $3.90 \mathrm{E}-04$ \\
\hline 20010802234106 & $1.38 \mathrm{E}-04$ & $6.87 \mathrm{E}-05$ & $1.10 \mathrm{E}-04$ & $1.97 \mathrm{E}-03$ & $2.01 \mathrm{E}-04$ \\
\hline 20031022114530 & $2.45 \mathrm{E}-04$ & 4.72E-04 & 7.53E-04 & $3.34 \mathrm{E}-03$ & $9.15 \mathrm{E}-04$ \\
\hline 20040109223531 & $1.54 \mathrm{E}-04$ & $2.90 \mathrm{E}-04$ & $4.63 \mathrm{E}-04$ & $2.36 \mathrm{E}-03$ & $5.20 \mathrm{E}-04$ \\
\hline 20050202023025 & $2.81 \mathrm{E}-02$ & 8.04E-02 & $1.28 \mathrm{E}-01$ & $1.70 \mathrm{E}-02$ & $2.90 \mathrm{E}-02$ \\
\hline 20060214152723 & $2.47 \mathrm{E}-04$ & $1.20 \mathrm{E}-05$ & $1.91 \mathrm{E}-05$ & $6.19 \mathrm{E}-04$ & $2.08 \mathrm{E}-05$ \\
\hline 20100207061000 & $2.16 \mathrm{E}-03$ & $6.13 \mathrm{E}-04$ & $9.78 \mathrm{E}-04$ & $6.74 \mathrm{E}-03$ & $1.80 \mathrm{E}-03$ \\
\hline 20100304001851 & $2.06 \mathrm{E}-03$ & $9.08 \mathrm{E}-04$ & $1.45 \mathrm{E}-03$ & $8.83 \mathrm{E}-03$ & $2.68 \mathrm{E}-03$ \\
\hline 20100710114332 & $2.81 \mathrm{E}-03$ & $3.80 \mathrm{E}-04$ & $6.07 \mathrm{E}-04$ & $5.63 \mathrm{E}-03$ & $1.22 \mathrm{E}-03$ \\
\hline 20101004132838 & $3.85 \mathrm{E}-04$ & $2.75 \mathrm{E}-04$ & 4.39E-04 & $3.35 \mathrm{E}-03$ & $6.85 \mathrm{E}-04$ \\
\hline 19991207212949 & $4.66 \mathrm{E}-03$ & $6.71 \mathrm{E}-03$ & $1.07 \mathrm{E}-02$ & $4.50 \mathrm{E}-03$ & $3.84 \mathrm{E}-03$ \\
\hline 20030314125412 & $1.71 \mathrm{E}-03$ & 2.97E-02 & 4.74E-02 & $1.42 \mathrm{E}-03$ & $4.21 \mathrm{E}-04$ \\
\hline 20030902182800 & $1.36 \mathrm{E}-02$ & $1.13 \mathrm{E}-03$ & $1.80 \mathrm{E}-03$ & $1.24 \mathrm{E}-02$ & 3.57E-03 \\
\hline 20050122203017 & $8.04 \mathrm{E}-03$ & $2.24 \mathrm{E}-03$ & $3.57 \mathrm{E}-03$ & $1.42 \mathrm{E}-02$ & $5.63 \mathrm{E}-03$ \\
\hline 20051015155108 & $1.69 \mathrm{E}-03$ & $6.39 \mathrm{E}-02$ & $1.02 \mathrm{E}-01$ & $7.66 \mathrm{E}-03$ & $8.95 \mathrm{E}-03$ \\
\hline 20070404063435 & $8.73 \mathrm{E}-04$ & $1.56 \mathrm{E}-04$ & $2.49 \mathrm{E}-04$ & $3.06 \mathrm{E}-03$ & 4.27E-04 \\
\hline 20090118141148 & $7.66 \mathrm{E}-02$ & 1.07E-02 & $1.70 \mathrm{E}-02$ & 4.02E-02 & $2.45 \mathrm{E}-02$ \\
\hline 20091219130217 & $1.91 \mathrm{E}-02$ & 1.09E-02 & $1.74 \mathrm{E}-02$ & 2.61E-02 & $1.93 \mathrm{E}-02$ \\
\hline 19960608231915 & $1.93 \mathrm{E}-02$ & $1.23 \mathrm{E}-02$ & $1.96 \mathrm{E}-02$ & 4.30E-02 & 2.67E-02 \\
\hline 20010703131042 & $2.07 \mathrm{E}-04$ & $4.50 \mathrm{E}-03$ & $7.19 \mathrm{E}-03$ & $5.58 \mathrm{E}-04$ & $3.04 \mathrm{E}-05$ \\
\hline 20020814135752 & $1.12 \mathrm{E}-02$ & $4.88 \mathrm{E}-03$ & 7.78E-03 & 2.37E-02 & $1.13 \mathrm{E}-02$ \\
\hline 20070816083928 & $1.18 \mathrm{E}-01$ & $1.95 \mathrm{E}-02$ & $3.12 \mathrm{E}-02$ & $8.06 \mathrm{E}-02$ & 4.98E-02 \\
\hline 20090516005351 & $9.45 \mathrm{E}-03$ & $1.60 \mathrm{E}-03$ & $2.55 \mathrm{E}-03$ & $8.65 \mathrm{E}-03$ & $3.20 \mathrm{E}-03$ \\
\hline 20100426025951 & $2.11 \mathrm{E}-03$ & $2.54 \mathrm{E}-04$ & $4.05 \mathrm{E}-04$ & $4.35 \mathrm{E}-03$ & $6.92 \mathrm{E}-04$ \\
\hline
\end{tabular}


Table 5. Peak horizontal ground acceleration.-Continued

\begin{tabular}{|c|c|c|c|c|c|}
\hline Earthquake origin time & Observed & AB-Cascadia & AB-Global & Geomatrix & $\begin{array}{l}\text { Zhao and } \\
\text { others (2006) }\end{array}$ \\
\hline 19971217043851 & $1.25 \mathrm{E}-03$ & $6.72 \mathrm{E}-04$ & $1.07 \mathrm{E}-03$ & $7.25 \mathrm{E}-03$ & $1.65 \mathrm{E}-03$ \\
\hline 19990128081005 & $1.19 \mathrm{E}-03$ & $3.49 \mathrm{E}-04$ & $5.57 \mathrm{E}-04$ & $2.45 \mathrm{E}-03$ & 4.42E-04 \\
\hline 20021107151406 & $1.43 \mathrm{E}-03$ & $1.29 \mathrm{E}-03$ & $2.05 \mathrm{E}-03$ & $8.86 \mathrm{E}-03$ & $2.73 \mathrm{E}-03$ \\
\hline 20031125201946 & $2.45 \mathrm{E}-04$ & $9.28 \mathrm{E}-05$ & $1.48 \mathrm{E}-04$ & $1.91 \mathrm{E}-03$ & $1.65 \mathrm{E}-04$ \\
\hline 20050116201752 & $3.99 \mathrm{E}-04$ & $1.12 \mathrm{E}-04$ & $1.78 \mathrm{E}-04$ & $2.42 \mathrm{E}-03$ & $2.35 \mathrm{E}-04$ \\
\hline 20050205033425 & $8.96 \mathrm{E}-03$ & $1.51 \mathrm{E}-02$ & $2.40 \mathrm{E}-02$ & $6.96 \mathrm{E}-03$ & $6.79 \mathrm{E}-03$ \\
\hline 20070130213744 & $1.41 \mathrm{E}-04$ & $1.23 \mathrm{E}-05$ & $1.96 \mathrm{E}-05$ & $9.16 \mathrm{E}-04$ & $2.22 \mathrm{E}-05$ \\
\hline 20071127114958 & $1.89 \mathrm{E}-03$ & 7.72E-04 & $1.23 \mathrm{E}-03$ & $8.47 \mathrm{E}-03$ & $2.00 \mathrm{E}-03$ \\
\hline 20080719092701 & $3.61 \mathrm{E}-04$ & $8.21 \mathrm{E}-05$ & $1.31 \mathrm{E}-04$ & $2.46 \mathrm{E}-03$ & 2.02E-04 \\
\hline 20090830145132 & $1.20 \mathrm{E}-02$ & $3.20 \mathrm{E}-03$ & $5.11 \mathrm{E}-03$ & $2.44 \mathrm{E}-02$ & $8.86 \mathrm{E}-03$ \\
\hline 20100103214805 & $9.54 \mathrm{E}-04$ & $1.13 \mathrm{E}-03$ & $1.80 \mathrm{E}-03$ & $9.15 \mathrm{E}-03$ & $2.60 \mathrm{E}-03$ \\
\hline 20040125114311 & $5.74 \mathrm{E}-03$ & $4.58 \mathrm{E}-03$ & $7.31 \mathrm{E}-03$ & $4.23 \mathrm{E}-03$ & $2.61 \mathrm{E}-03$ \\
\hline 20050208144821 & $1.48 \mathrm{E}-04$ & $6.55 \mathrm{E}-04$ & $1.04 \mathrm{E}-03$ & $6.97 \mathrm{E}-04$ & $3.45 \mathrm{E}-05$ \\
\hline 20100626053019 & $2.18 \mathrm{E}-02$ & $3.91 \mathrm{E}-03$ & $6.23 \mathrm{E}-03$ & $1.78 \mathrm{E}-02$ & $7.76 \mathrm{E}-03$ \\
\hline 19960322032420 & $1.30 \mathrm{E}-03$ & $8.95 \mathrm{E}-04$ & $1.43 \mathrm{E}-03$ & 8.72E-03 & $1.97 \mathrm{E}-03$ \\
\hline 20031210043811 & $2.58 \mathrm{E}-03$ & $2.43 \mathrm{E}-03$ & $3.88 \mathrm{E}-03$ & $1.97 \mathrm{E}-02$ & $6.18 \mathrm{E}-03$ \\
\hline 20041008082753 & 7.71E-03 & $1.87 \mathrm{E}-03$ & $2.98 \mathrm{E}-03$ & $1.07 \mathrm{E}-02$ & $3.44 \mathrm{E}-03$ \\
\hline 20080509215129 & $1.04 \mathrm{E}-02$ & $1.05 \mathrm{E}-02$ & $1.68 \mathrm{E}-02$ & $1.67 \mathrm{E}-02$ & $1.22 \mathrm{E}-02$ \\
\hline 20081209062359 & $2.62 \mathrm{E}-02$ & $2.12 \mathrm{E}-03$ & $3.38 \mathrm{E}-03$ & $1.57 \mathrm{E}-02$ & 4.90E-03 \\
\hline 20091124124715 & $6.06 \mathrm{E}-04$ & 2.09E-05 & $3.33 \mathrm{E}-05$ & $1.30 \mathrm{E}-03$ & $3.55 \mathrm{E}-05$ \\
\hline 20091124124716 & $6.06 \mathrm{E}-04$ & $2.09 \mathrm{E}-05$ & $3.33 \mathrm{E}-05$ & $1.30 \mathrm{E}-03$ & $3.55 \mathrm{E}-05$ \\
\hline 20100105121532 & $8.39 \mathrm{E}-03$ & $1.48 \mathrm{E}-03$ & $2.36 \mathrm{E}-03$ & $1.30 \mathrm{E}-02$ & $3.52 \mathrm{E}-03$ \\
\hline 20100411094025 & $1.94 \mathrm{E}-02$ & $3.64 \mathrm{E}-03$ & $5.80 \mathrm{E}-03$ & $2.13 \mathrm{E}-02$ & $8.11 \mathrm{E}-03$ \\
\hline 20060928062209 & $6.67 \mathrm{E}-03$ & $1.78 \mathrm{E}-03$ & $2.84 \mathrm{E}-03$ & $1.18 \mathrm{E}-02$ & $3.44 \mathrm{E}-03$ \\
\hline 20061226123413 & $1.84 \mathrm{E}-03$ & $6.82 \mathrm{E}-04$ & $1.09 \mathrm{E}-03$ & $8.70 \mathrm{E}-03$ & $1.60 \mathrm{E}-03$ \\
\hline 20070930020830 & $5.06 \mathrm{E}-03$ & $6.73 \mathrm{E}-04$ & $1.07 \mathrm{E}-03$ & $8.11 \mathrm{E}-03$ & $1.50 \mathrm{E}-03$ \\
\hline 20080908185206 & $8.76 \mathrm{E}-04$ & $1.38 \mathrm{E}-04$ & $2.20 \mathrm{E}-04$ & $1.12 \mathrm{E}-03$ & $6.88 \mathrm{E}-05$ \\
\hline 20100718130409 & $1.18 \mathrm{E}-03$ & $2.31 \mathrm{E}-04$ & $3.69 \mathrm{E}-04$ & $3.66 \mathrm{E}-03$ & 3.99E-04 \\
\hline 20011012150216 & $1.70 \mathrm{E}-01$ & $3.87 \mathrm{E}-02$ & $6.14 \mathrm{E}-02$ & $5.42 \mathrm{E}-02$ & 4.21E-02 \\
\hline 20090218215345 & $3.60 \mathrm{E}-02$ & $3.20 \mathrm{E}-03$ & $5.10 \mathrm{E}-03$ & $1.78 \mathrm{E}-02$ & $6.19 \mathrm{E}-03$ \\
\hline 20020426160607 & $9.08 \mathrm{E}-02$ & $1.61 \mathrm{E}-01$ & $2.40 \mathrm{E}-01$ & $8.10 \mathrm{E}-02$ & $1.46 \mathrm{E}-01$ \\
\hline 20030317163617 & $6.00 \mathrm{E}-04$ & $4.10 \mathrm{E}-03$ & $6.51 \mathrm{E}-03$ & $6.65 \mathrm{E}-03$ & $2.95 \mathrm{E}-03$ \\
\hline 20100103223627 & $2.24 \mathrm{E}-03$ & $6.45 \mathrm{E}-03$ & $1.02 \mathrm{E}-02$ & $1.08 \mathrm{E}-02$ & $5.95 \mathrm{E}-03$ \\
\hline 20000108164720 & $1.06 \mathrm{E}-02$ & $3.91 \mathrm{E}-02$ & $6.24 \mathrm{E}-02$ & $7.01 \mathrm{E}-03$ & $4.31 \mathrm{E}-03$ \\
\hline 20071031033015 & $3.09 \mathrm{E}-03$ & $2.06 \mathrm{E}-02$ & $3.28 \mathrm{E}-02$ & $3.72 \mathrm{E}-03$ & $1.09 \mathrm{E}-03$ \\
\hline 20071219093027 & $1.85 \mathrm{E}-02$ & $1.94 \mathrm{E}-02$ & $3.08 \mathrm{E}-02$ & $2.38 \mathrm{E}-02$ & 1.63E-02 \\
\hline 19960610152456 & $1.88 \mathrm{E}-01$ & $8.74 \mathrm{E}-02$ & 1.39E-01 & $1.24 \mathrm{E}-01$ & $1.22 \mathrm{E}-01$ \\
\hline 20100718133459 & $6.56 \mathrm{E}-04$ & $2.22 \mathrm{E}-03$ & $3.53 \mathrm{E}-03$ & $3.99 \mathrm{E}-03$ & $1.02 \mathrm{E}-03$ \\
\hline 20070928133857 & 4.02E-04 & $1.23 \mathrm{E}-02$ & $1.96 \mathrm{E}-02$ & $2.01 \mathrm{E}-03$ & $1.13 \mathrm{E}-04$ \\
\hline
\end{tabular}


Table 5. Peak horizontal ground acceleration.-Continued

\begin{tabular}{cccccc}
\hline Earthquake origin time & Observed & AB-Cascadia & AB-Global & Geomatrix & $\begin{array}{c}\text { Zhao and } \\
\text { others (2006) }\end{array}$ \\
\hline 20090319181740 & $2.19 \mathrm{E}-02$ & $1.91 \mathrm{E}-04$ & $3.05 \mathrm{E}-04$ & $4.22 \mathrm{E}-03$ & $2.12 \mathrm{E}-04$ \\
\hline 20091007220314 & $8.07 \mathrm{E}-04$ & $1.23 \mathrm{E}-03$ & $1.95 \mathrm{E}-03$ & $2.75 \mathrm{E}-03$ & $2.34 \mathrm{E}-04$ \\
\hline 20031117064306 & $2.57 \mathrm{E}-03$ & $1.07 \mathrm{E}-02$ & $1.71 \mathrm{E}-02$ & $3.17 \mathrm{E}-02$ & $1.52 \mathrm{E}-02$ \\
\hline 19960610040335 & $1.39 \mathrm{E}-01$ & $1.55 \mathrm{E}-01$ & $2.32 \mathrm{E}-01$ & $1.76 \mathrm{E}-01$ & $2.29 \mathrm{E}-01$ \\
\hline 20060503152640 & $6.31 \mathrm{E}-03$ & $1.10 \mathrm{E}-03$ & $1.76 \mathrm{E}-03$ & $8.06 \mathrm{E}-03$ & $8.98 \mathrm{E}-04$ \\
\hline 20070401203958 & $5.94 \mathrm{E}-03$ & $3.78 \mathrm{E}-02$ & $6.00 \mathrm{E}-02$ & $3.44 \mathrm{E}-02$ & $2.19 \mathrm{E}-02$ \\
\hline 20090929174810 & $9.13 \mathrm{E}-02$ & $7.88 \mathrm{E}-02$ & $1.26 \mathrm{E}-01$ & $1.37 \mathrm{E}-01$ & $1.82 \mathrm{E}-01$ \\
\hline
\end{tabular}


Table 6. Systematic Offset of the Zhao and others (2006) equation for Pacific region data. (PGA, peak horizontal ground acceleration, $5 \mathrm{~Hz}$ and $1 \mathrm{~Hz}$ represent 5 and $1 \mathrm{Hertz}$ or 0.2 seconds and 1.0 second periods. $\mathrm{km}$, kilometers )

\begin{tabular}{|c|c|c|c|}
\hline & PGA & 5HZ & 1HZ \\
\hline ZHAO & -0.0542 & 0.0777 & 0.2018 \\
\hline
\end{tabular}

Table 7. Single Station Sigma, distance $\leq 300 \mathrm{~km}, \mathrm{M} \geq 6.0$. (PGA, peak horizontal ground acceleration, $5 \mathrm{~Hz}$ and $1 \mathrm{~Hz}$ represent 5 and $1 \mathrm{Hertz}$ or 0.2 seconds and 1.0 second periods; km, kilometers)

\begin{tabular}{|c|c|c|c|}
\hline & Zhao and others (2006) & Geomatrix & Atkinson and Boore (2003) \\
\hline PGA & 0.7356 & 0.8199 & 0.9952 \\
\hline 5HZ & .792 & .852 & .8874 \\
\hline $1 \mathrm{HZ}$ & .6538 & .6928 & .7234 \\
\hline
\end{tabular}

Table 8. Station Sigma, distance $\leq 300 \mathrm{~km}, \mathrm{M} \geq 6.0$. (PGA, peak horizontal ground acceleration, $5 \mathrm{~Hz}$ and $1 \mathrm{~Hz}$ represent 5 and 1 Hertz or 0.2 seconds and 1.0 second periods; km, kilometers)

\begin{tabular}{|c|c|c|c|}
\hline & Zhao and others (2006) & Geomatrix & Atkinson and Boore (2003) \\
\hline PGA & 0.5685 & 0.5156 & 0.5934 \\
\hline 5HZ & .5616 & .5863 & .5017 \\
\hline 1HZ & .2568 & .2695 & .2176 \\
\hline
\end{tabular}

Table 9. Total Sigma, distance $\leq 300 \mathrm{~km}, \mathrm{M} \geq 6.0$. (PGA, peak horizontal ground acceleration, $5 \mathrm{~Hz}$ and $1 \mathrm{~Hz}$ represent 5 and 1 Hertz or 0.2 seconds and 1.0 second periods; $\mathrm{km}$, kilometers)

\begin{tabular}{|c|c|c|c|}
\hline & Zhao and others (2006) & Geomatrix & Atkinson and Boore (2003) \\
\hline PGA & 0.9297 & 0.9685 & 1.1587 \\
\hline 5HZ & .9709 & 1.0342 & 1.0194 \\
\hline 1HZ & .7024 & .7434 & .7554 \\
\hline
\end{tabular}




\title{
Appendix 1. Lessons of the M8.3 Tokachi-Oki and the M9 Tohoku Earthquakes
}

\author{
By Stephen Harmsen
}

The ideal data set for predicting future ground motions in American Samoa from TongaKermadec subduction events would be composed of extensive strong-motion recordings of past TongaKermadec subduction events for a range of distances and event magnitudes that span the expected events. However, such data are extremely sparse. We examined Global Digital Seismic Network (GDSN) records from several Pacific Ocean trench regions, including Tonga and Kermadec, and found several strong ground motion records that either are or are suspected to be from oceanic-platesubduction events. The criteria for considering the event subduction are that they are relatively shallow (hypocenters in the 0 to 50 kilometer $(\mathrm{km})$ range), with epicenters in the subducting slab region and Harvard moment tensor solutions with strongly reverse-slip motion. We recognize that these criteria are necessary but not sufficient to make such a determination. One source of potential ambiguity is that outer rise earthquakes can nucleate very close to the top of the subducting slab and tend to have reverseslip (compressional) mechanisms prior to large nearby subduction events, whereas they tend to have normal (tensional) mechanisms after large subduction events (Lay and others, 1989).

The 1.0-second (sec) spectral acceleration data from interface events, as we define them, are shown in Figure 1-1, and are compared with Zhao and others (2006) subduction event predictions for sources having magnitude in the range 6 less than $M$ less than 8 . The curves in fig. 1-1 are based on an assumed site average shear-wave velocity (Vs30) in the top $30 \mathrm{~m}$ of 600 meters per second $(\mathrm{m} / \mathrm{s})$. The GDSN data are from stations that are generally located on volcanic rock outcrops, which may have Vs30 more or less than this value. Figure 1-1 shows that there are too few GDSN data in our study to provide strong constraints on which model or models to use for predicting ground motions. As is commonly done in probabilistic seismic hazard analysis (PSHA) studies, we study information from similar, but distant, tectonic environments to try to guide our choice of models for predicting American Samoa ground motions. 


\section{Zhao et al. Interface \& GDSN Data}

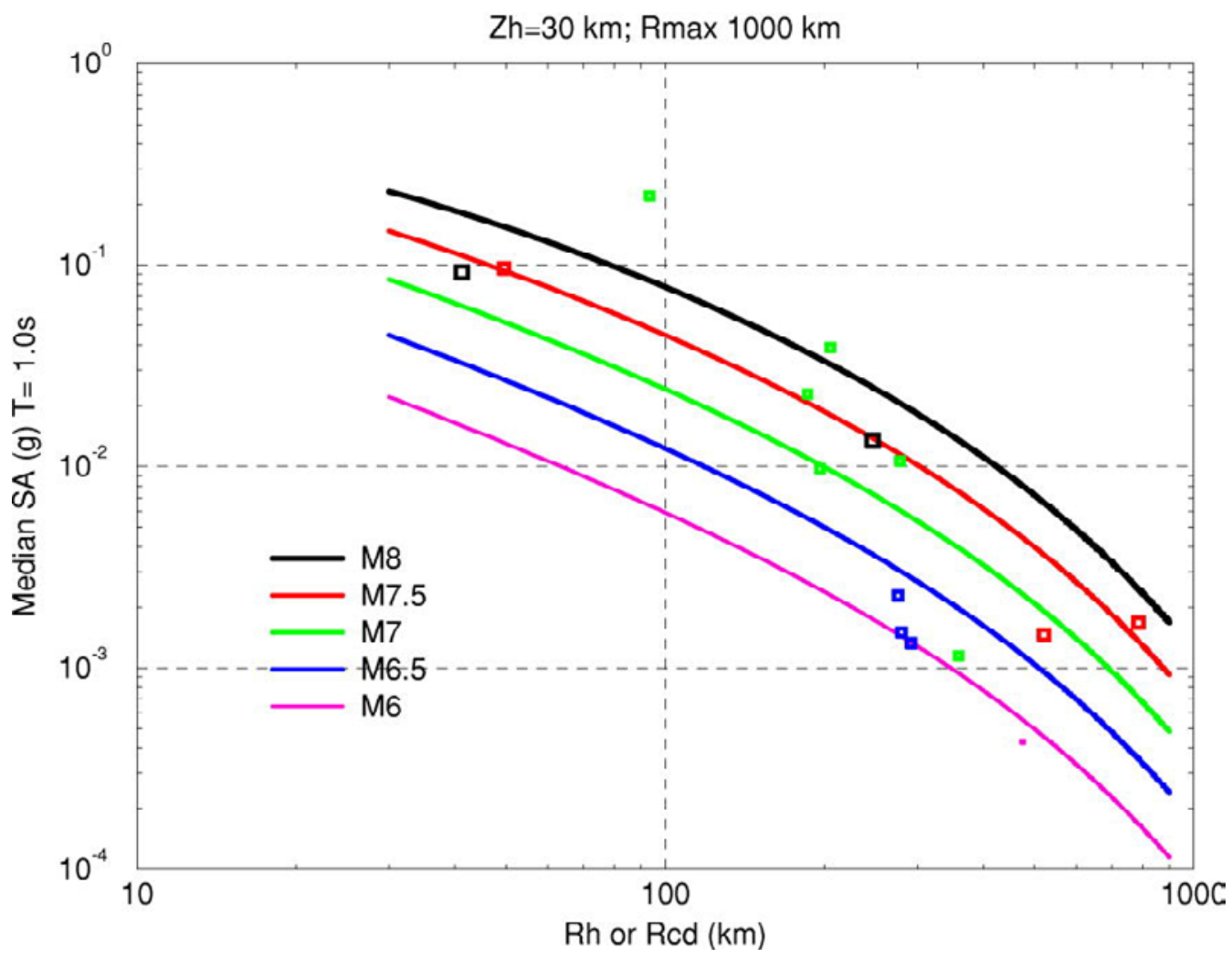

Figure 1-1. 1-second spectral acceleration data from Global Digital Seismic Network for known or suspected interface earthquakes and predictions of SA from the Zhao and others (2006) model. Data and model correspond to the geometric mean of the peak motions on the two horizontal-component response functions. (km, kilometers; g, acceleration of gravity)

\section{Tokachi-Oki Earthquake of September 26, 2003}

The Tokachi-Oki mainshock was well recorded by Japan's KiKNet and KNet seismograph networks, with at least 360 stations providing usable seismograms. Japan's dense KiKNet and K-Net seismograph networks were installed beginning in 1996 following the 1995 Hyogoken-nanbu (Kobe) earthquake. Tokachi-Oki seismograms were processed to supply spectral response and peak ground velocity, with results available at the USGS Shake Map site: http://earthquake.usgs.gov/earthquakes/shakemap/atlas/shake/200309251950/, last accessed May 4, 2011. To compare the motions with available ground-motion prediction equations (GMPEs), we need a geometry model of the part of the plate interface that ruptured during that earthquake. Figure 1-2 shows the projection of the Tokachi-Oki rupture plane to the Earth's surface. In Figure 1-2 and later we use the rupture model of Kamae and Kawabe (2004) to infer closest distance, $r_{c d}$. In their model, the rupture surface has length $128 \mathrm{~km}$ and width $80 \mathrm{~km}$. Its dip is $26^{\circ}$. For comparison, the Geomatrix Consultants (1995) expected length of an M8.3 subduction source is $261 \mathrm{~km}$. The compactness of the source may in part be due to its relatively great width, with an aspect ratio of 1.6. Many subduction sources may be expected to have aspect ratios of 2.5 or greater. We use the Geomatrix expected length to predict rupture length of M7 to M9 subduction events on the Tonga-Kermadec and New Hebrides interfaces. 


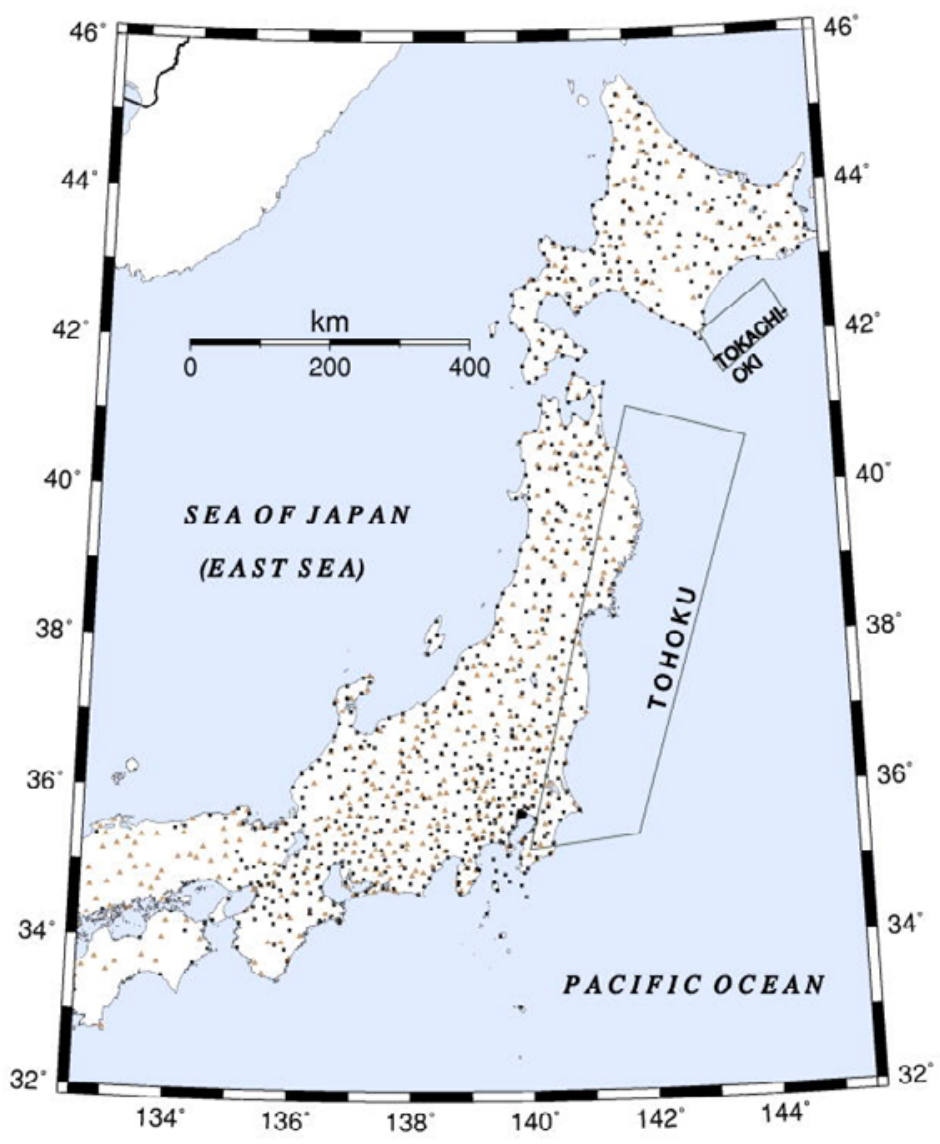

Figure 1-2. Map of a portion of Japan showing locations of KiKNet stations (brown symbols) and KNet stations (black symbols) as well as rupture zones for two important subduction events, Tokachi-Oki and Tohoku. All pictured stations provided records from the Tohoku main shock, whereas only about $1 / 3$ of them provided data from Tokachi-Oki. (km, kilometers)

Figure 1-3 shows the Tokachi-Oki peak horizontal ground accelerations ( PGA) data (geometric mean of the two horizontal components) and three GMPEs for subduction events with M8.3, assuming a uniform $600 \mathrm{~m} / \mathrm{s}$ site condition, that is, National Earthquake Hazard Reduction Program (NEHRP) Class $\mathrm{C}$ soil classification. In the 200 to $300 \mathrm{~km}$ range, where predictions are important to the American Samoa seismic hazard, these models tend to over-predict the motion, with the Zhao and others (2006) model exhibiting the least bias. Site condition for most of these data is NEHRP Class C, D, or E soil, reported at $h t t p: / / w w w . k$-net.bosai.go.jp/. Given these site conditions, a factor of two (plus or minus) soil amplification compared to rock at the same location is to be expected. The curves, which correspond to a very stiff soil or firm rock, are clearly biased high compared to Tokachi-Oki data, especially if those data had been scaled to a common site condition of $600 \mathrm{~m} / \mathrm{s} \mathrm{Vs} 30$, at distances in the $200-500 \mathrm{~km}$ range. 


\section{Tokachi-Oki Main Shock Sept 26, 2003}

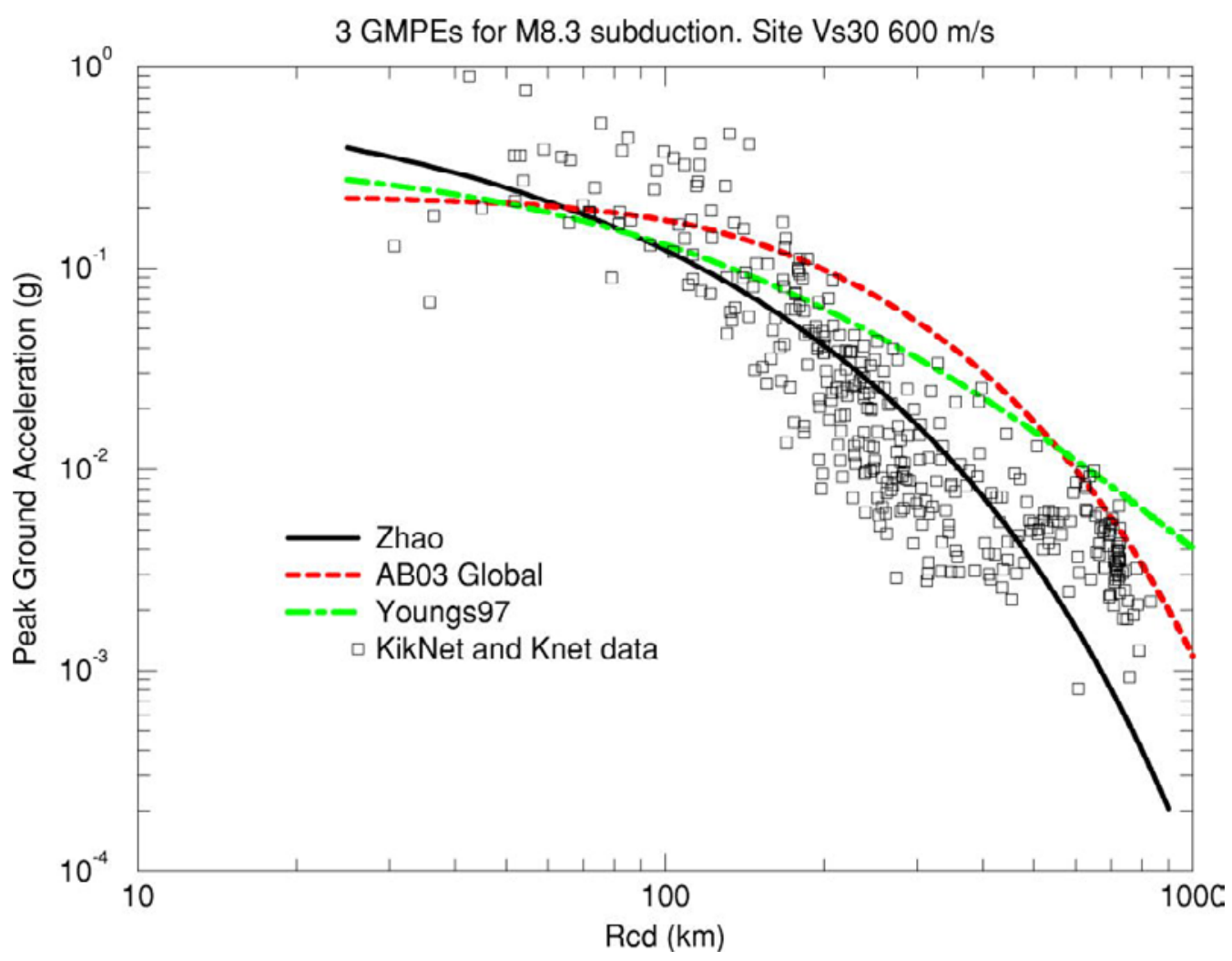

Figure 1-3. Tokachi-Oki main shock data and three ground-motion models for peak ground acceleration from subduction source with M8.3 and depth $25 \mathrm{~km}$. The data are mostly from sites located on soil with NEHRP site class C, D, and E. The curves, however, correspond to an upper-C site class. (GMPEs, ground-motion prediction equations, $\mathrm{m} / \mathrm{s}$, meters per second; $\mathrm{g}$, acceleration of gravity; km, kilometers; NEHRP, National Earthquake Hazard Reduction Program)

Figure 1-4 shows the 0.3 -s spectral acceleration data and three GMPE models, again computed for a $600 \mathrm{~m} / \mathrm{s}$ site condition. The 0.3 -s data are here used as a proxy for 0.2 -s data, because 0.2 -s data are not available at the Shake Map web site, but seismic hazard at 0.2-s period is discussed in this report. Stations in the Tokyo subnet of K-Net are highlighted in red. These Tokyo stations are on thin to thick soil, often NEHRP class D or even E, as are most other K-Net stations. In the 200 to $300 \mathrm{~km}$ range, these GMPEs tend to over predict the data, especially when a factor of two (plus or minus) is divided out to remove expected soil amplification. The Zhao and others (2006) GMPE clearly exhibits the least high bias in that distance range. 


\section{Tokachi-Oki Main Shock Sept 26, 2003}

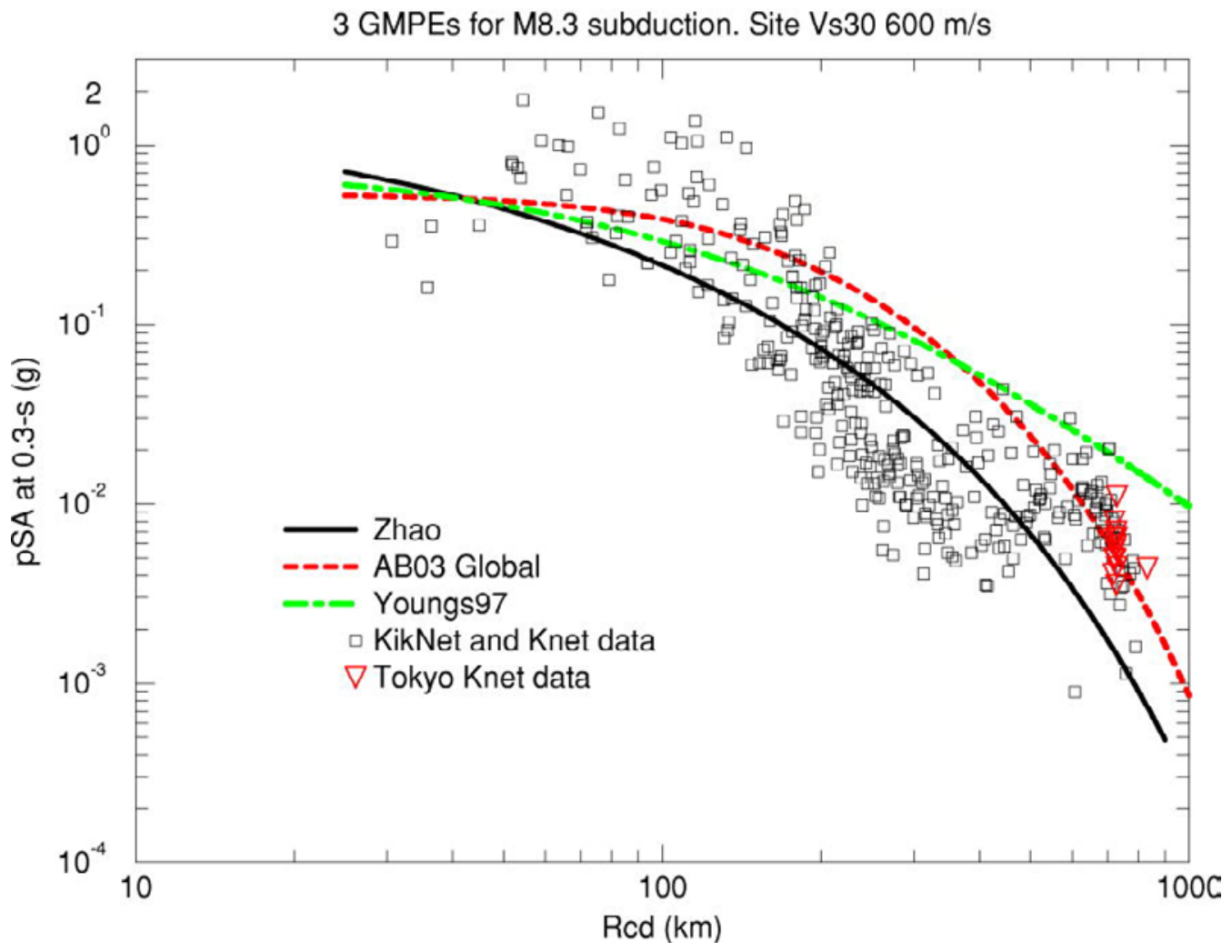

Figure 1-4. Tokachi-Oki main shock data and three ground-motion models for pseudo spectral acceleration (pSA) at 0.3 -s period (5 percent damping) from subduction source with $\mathrm{M} 8.3$ and depth $25 \mathrm{~km}$. The data are mostly from sites located on soil with NEHRP site class C, D, and E. The curves, however, correspond to an upper-C site class. ( $\mathrm{km}$, kilometers; GMPEs, ground-motion prediction equations, $\mathrm{m} / \mathrm{s}$, meters per second; $\mathrm{s}$, seconds; $\mathrm{g}$, acceleration of gravity; km, kilometers; NEHRP, National Earthquake Hazard Reduction Program)

Figure 1-5 below shows the Tokachi-Oki ground motion data and three GMPEs for 1-s spectral acceleration. The data correspond to soil sites, and if they are reduced by a factor of two (plus or minus) to remove soil amplification, they tend to fall below the curves in the important distance range of 200 to $500 \mathrm{~km}$. Again, the Zhao and others (2006) model tends to have the smallest bias in this distance range. The models have comparable amplitudes in the near source distance range $\left(\mathrm{R}_{\mathrm{cd}}\right.$ less than $\left.100 \mathrm{~km}\right)$. 


\section{Tokachi-Oki Main Shock Sept 26, 2003}

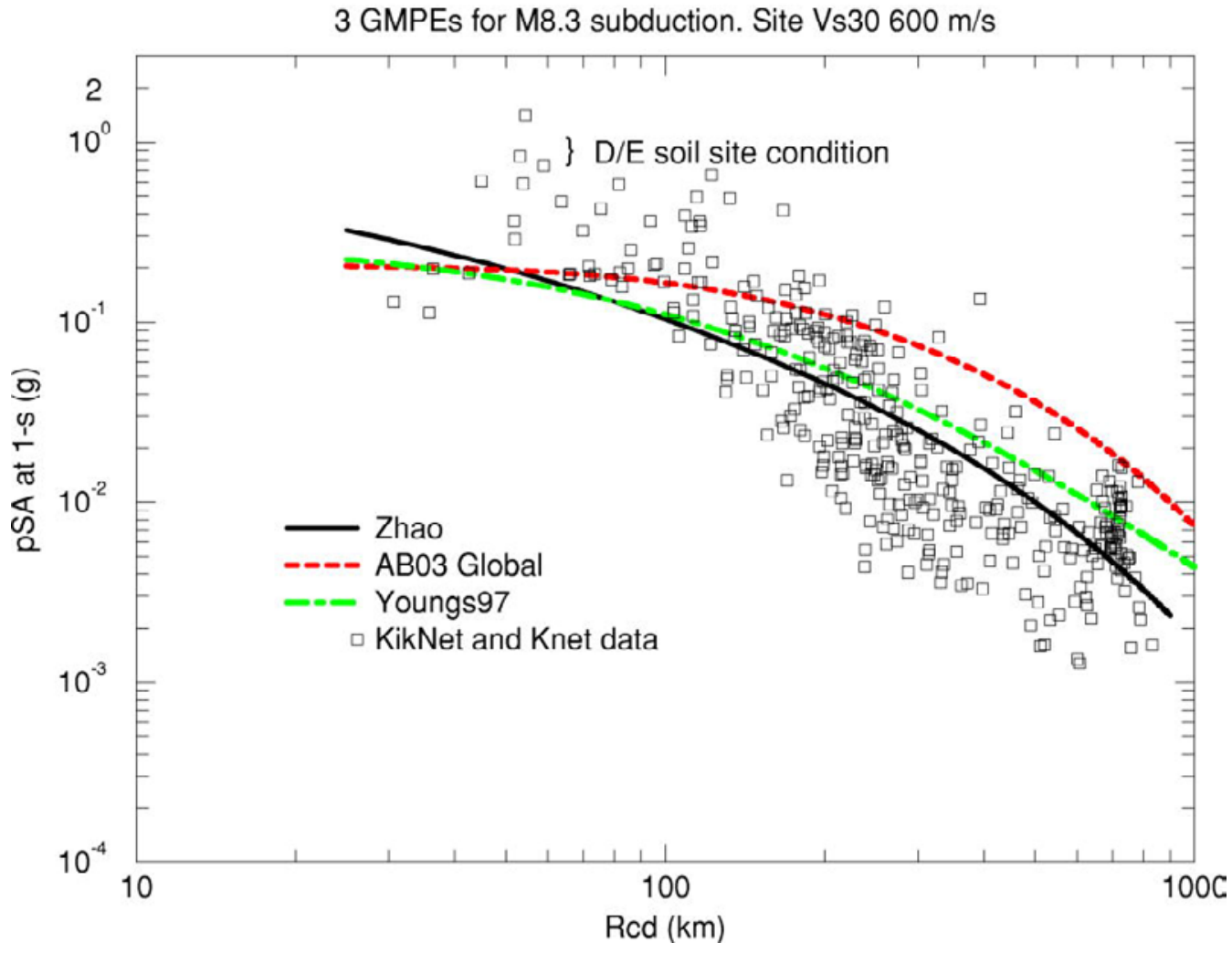

Figure 1-5. Tokachi-Oki main shock data and three ground-motion models for pseudo spectral acceleration (SA) at 1.0-s period (5 percent damping) from subduction source with M8.3 and depth $25 \mathrm{~km}$. (GMPEs, ground-motion prediction equations, $\mathrm{m} / \mathrm{s}$, meters per second; s, seconds; $\mathrm{g}$, acceleration of gravity; km, kilometers; NEHRP, National Earthquake Hazard Reduction Program)

\section{Tohoku Earthquake of March 11, 2011}

Besides the obvious lesson that M9 subduction events produce large, destructive tsunamis (often with columns of water having 10-m depth rushing inland and destroying everything and everyone in their path) the Tohoku earthquake provides valuable information about ground acceleration at a broad range of distances as recorded on a variety of soil and rock sites. Approximately 1,200 K-Net and KiKNet instruments provided useful seismograms from the Tohoku earthquake. These seismograms were processed to supply spectral response and peak ground velocity, with results available at the USGS Shake Map site: http://earthquake.usgs.gov/earthquakes/eqinthenews/2011/usc0001xgp/, last accessed May 4, 2011. To compare the motions with available GMPEs, we need a geometry model of the part of the plate interface that ruptured during that earthquake. In figure 1-2 above, and in the below figures, we use the rupture model of Gavin Hayes, USGS, which has length $621 \mathrm{~km}$ and width $254 \mathrm{~km}$. The Hayes model is more fully described at http://earthquake.usgs.gov/earthquakes/eqinthenews/2011/usc0001xgp/finite_fault.php. For comparison, the Geomatrix expected length of an M9 megathrust event is $833 \mathrm{~km}$. According to the Hayes model, the shorter length of the Tohoku rupture is more than compensated by the greater than usual width, 
which corresponds to a very gentle interface dip of about $10^{\circ}$. The Tonga trench interface has a much steeper dip, and is expected to produce relatively long ruptures for a given magnitude.

Most of the stations in Japan's KiKNet network are located on sedimentary rock or on thin soil over sedimentary rock, and correspond, more often than not, to the NEHRP Class C geotechnical site class, 350 less than Vs30 less than $600 \mathrm{~m} / \mathrm{s}$. Most of the stations in the K-Net network are located on thin to thick sediment over sedimentary rock, and mostly correspond to NEHRP Class E (120 to 180 $\mathrm{m} / \mathrm{s}$ ) and Class D (180 to $350 \mathrm{~m} / \mathrm{s}$ ) site classes. Detailed geotechnical logs are available for many of these KNet stations at http://www.k-net.bosai.go.jp/. This report, however, primarily focuses on seismic hazard corresponding to rock at the NEHRP B/C interface, with Vs30 $=760 \mathrm{~m} / \mathrm{s}$. When comparing prediction curves with data, we choose a uniform $600 \mathrm{~m} / \mathrm{s}$ rock site condition, which is a compromise between the data and the American Samoa modeling work.

Figure 1-6 below shows the PGA data (geometric mean of the two horizontal components) and three GMPE models. The data generally plot below the models except at near-source distances, where several data plot two to three times above the prediction. If we could remove site response from the data, they would tend to plot even further below the predictions, except at relatively near-source distances, where they would be close to the predictions. For sites in American Samoa, the distance to the Tonga-interface source is about 200-250 km. Samoa does not lie in the direction of slip. Pago Pago and the rest of American Samoa are northeast of the trench, just as Tokyo is southwest of the Tohoku rupture, although only $60 \mathrm{~km}$ or so distant. Tokyo KNet data are plotted as red triangles in figure 1-6. Figure 1-6 clearly shows that of the three GMPEs we have been considering, only the Zhao 2006 model does a reasonably good job of fitting the data in the inner $300 \mathrm{~km}$. Although the Zhao ground-motion model was not designed to fit data beyond $300 \mathrm{~km}$, we continue to employ it to predict ground motions to a maximum distance of $1,000 \mathrm{~km}$. 


\section{Tohoku Main Shock Mar 112011}

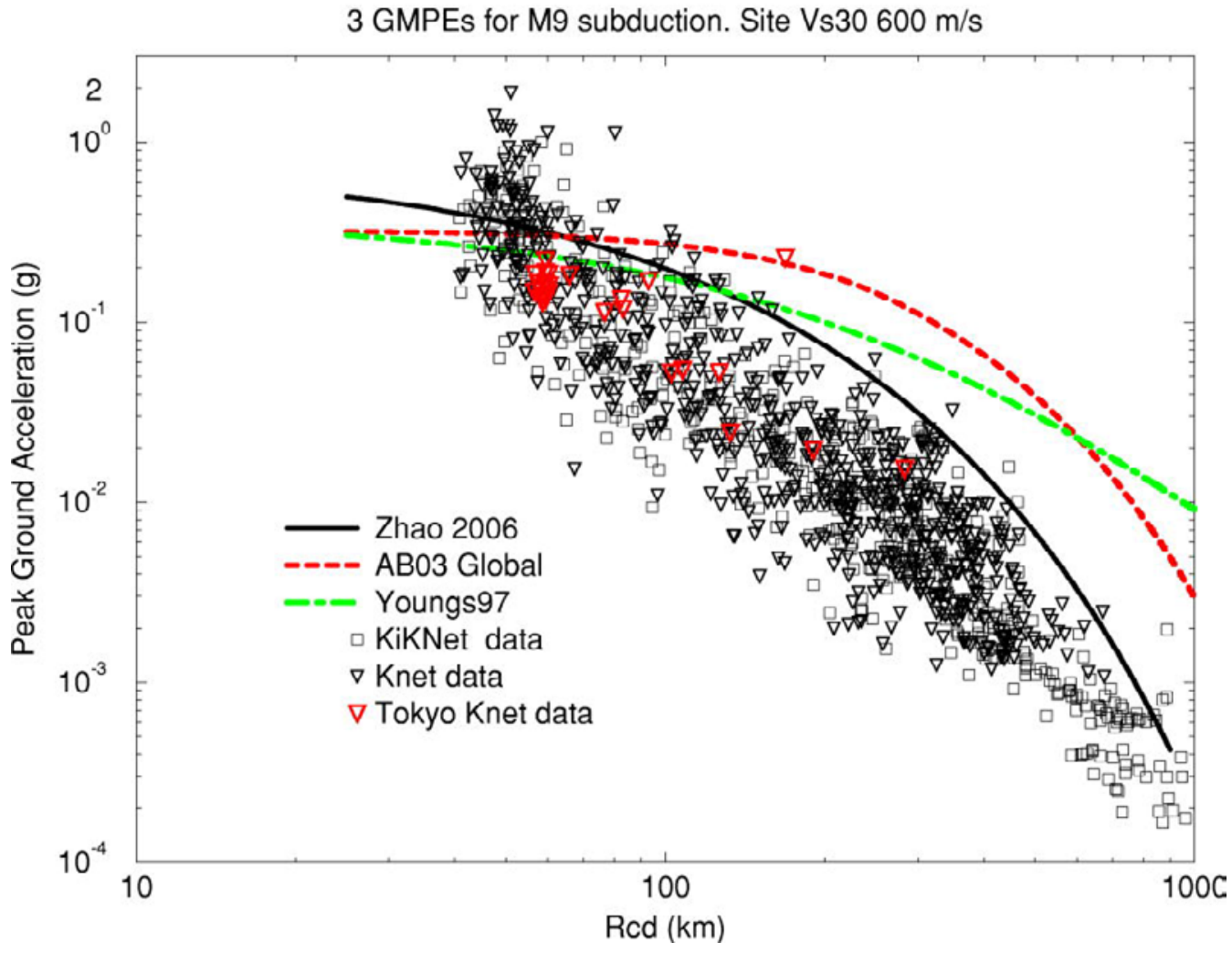

Figure 1-6. Peak ground acceleration models and data for an M9 megathrust earthquake. (GMPEs, groundmotion prediction equations, $\mathrm{m} / \mathrm{s}$, meters per second; $\mathrm{g}$, acceleration of gravity; $\mathrm{km}$, kilometers)

Figure 1-7 below shows the 0.3 -s Tohoku data (geometric mean of the two horizontal components) and three subduction GMPEs. As in figure 1-6, the Zhao 2006 model outperforms the others in goodness-of-fit. These data tend to justify the exclusive use of the Zhao 2006 model, given these three GMPEs to choose among. Data corresponding to 0.2 -s spectral period were not available from the Shake Map web site, so we are using these 0.3-s spectral period data to guide our thinking about the expected behavior of 0.2 -s data. 


\section{Tohoku Main Shock Mar 112011}

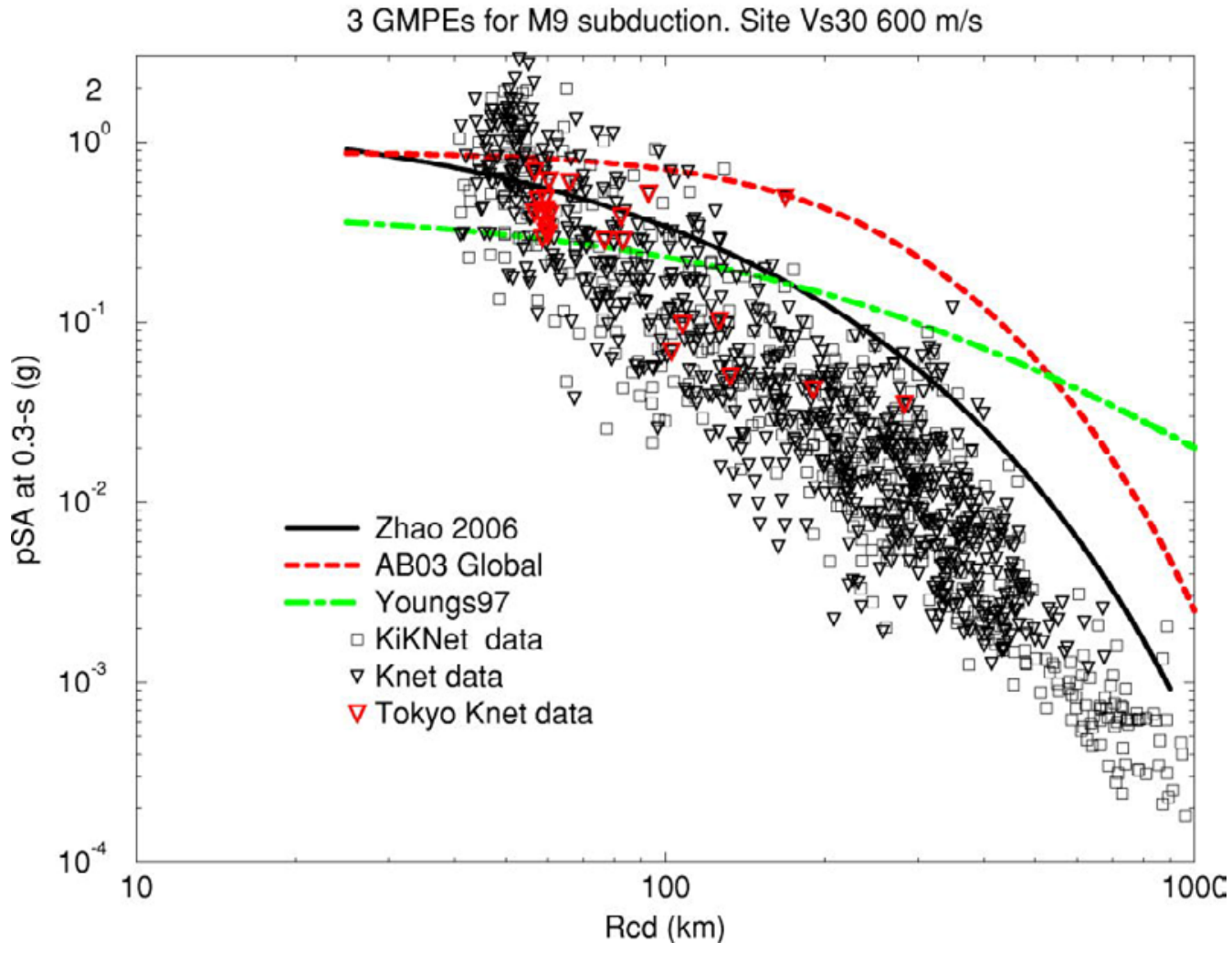

Figure 1-7. Data and GMPEs for 0.3-s pseudo spectral acceleration (pSA). Rcd is the closest distance from the site to the rupture surface. (GMPEs, ground-motion prediction equations, $\mathrm{m} / \mathrm{s}$, meters per second; s, seconds; $\mathrm{g}$, acceleration of gravity; km, kilometers; NEHRP, define here)

Figure 1-8 below shows the 1.0-s Tohoku data (geometric mean of the two horizontal components) and three GMPEs for an M9 interface earthquake. As usual, the Zhao 2006 model clearly outperforms the others at most distances and this plot tends to justify the exclusive use of the Zhao 2006 model with subduction-source branches of the logic tree. 


\section{Tohoku Main Shock Mar 112011}

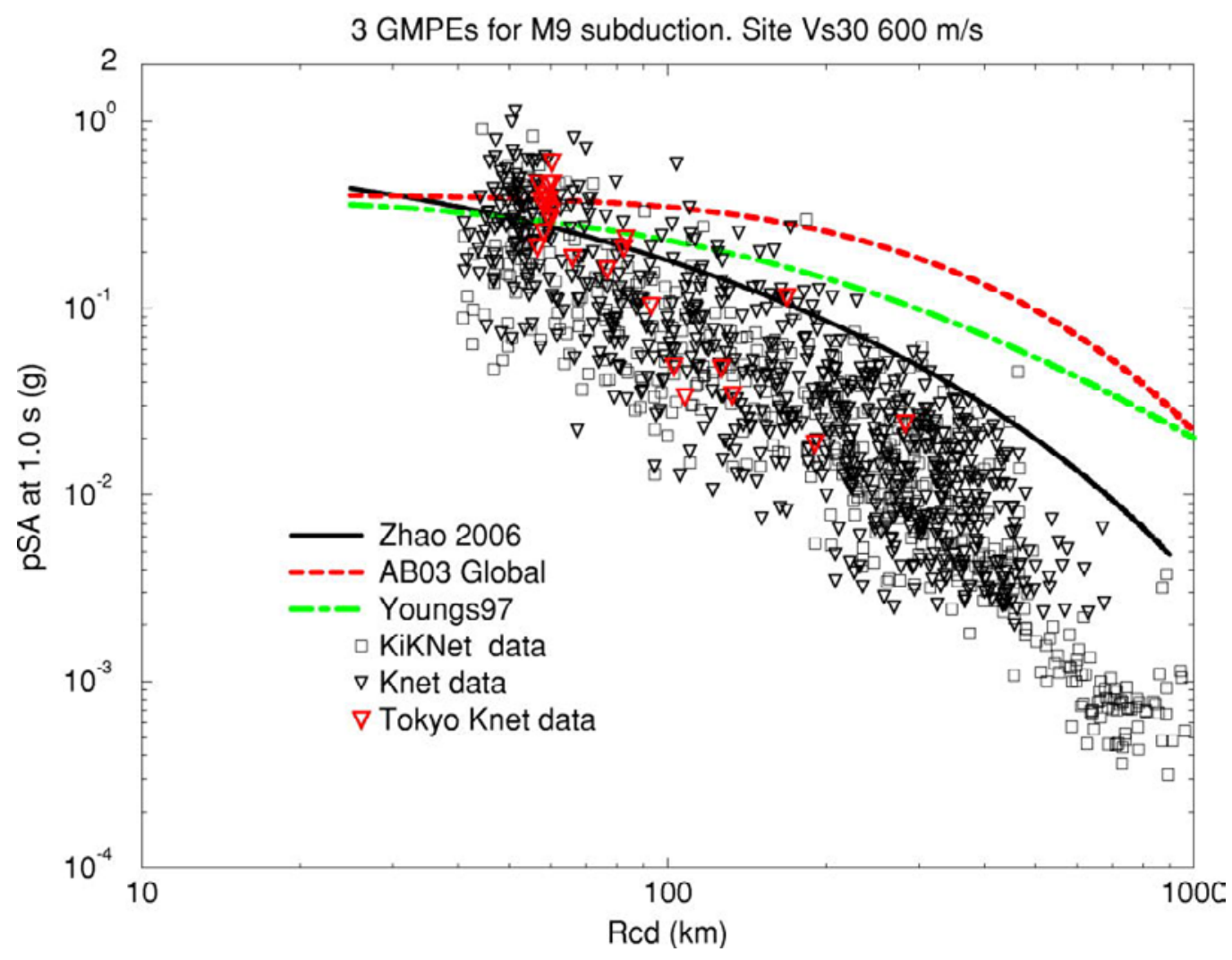

Figure 1-8. Data and GMPEs for 1.0-s pseudo spectral acceleration (pSA). Rcd is the closest distance from the site to the rupture surface. ( $\mathrm{s}$, seconds; $\mathrm{km}$, kilometers; GMPEs, ground-motion prediction equations, $\mathrm{m} / \mathrm{s}$, meters per second; $g$, acceleration of gravity; km, kilometers; NEHRP, define here)

The extensive KiKNet and K-Net data from the M9 Tohoku earthquake begin to fill in a big gap in strong-motion data from megathrust events. Questions remain about the applicability of these data to other tectonic plates with their unique rock properties, slab dips, and convergence rates. Still, we believe that data from similar events and tectonic environments are preferable to no data as aids when making decisions about models to use in the American Samoa PSHA.

\section{Conclusion}

Figures $1-3$ to $1-8$ strongly suggest that there is no basis for raising the Zhao curve from the predicted value the way we have done for 1.0 -s and for 0.2 -s SA associated with intraplate sources, and no reason to give other GMPEs a positive weight, at least at for source-to-station distances greater than about $80 \mathrm{~km}$. For interface source ground-motion prediction, we use the Zhao and others (2006) model as published, with 25 percent uncertainty branches on the median when $M$ less than 8.5 , and 50 percent uncertainty branches on the median when $\mathrm{M}$ greater than or equal to 8.5. This additional epistemic uncertainty is used as a substitute for alternate published GMPEs, which we found less appropriate for modeling the data sets we studied. 


\section{References Cited}

Geomatrix Consultants, 1995, Seismic design mapping state of Oregon: Oakland, Calif., Geomatrix Consultants, prepared for Oregon Dept. of Transportation, Transportation Building, Salem, Oreg., Section 3, 17 p.

Kamae, K., and Kawabe, H., 2004, Source model composed of asperities for the 2003 Tokachi-Oki, Japan, earthquake $\left(\mathrm{M}_{\mathrm{JMA}}=8.0\right)$ estimated by the empirical Green's function method: Earth Planets Space, v 56, p. 323-327.

Lay, Thorne, Astiz, Luciana, Kanamori, Hiroo, and Christensen, D.H., 1989, Temporal variation of large intraplate earthquakes in coupled subduction zones: Physics of the Earth and Planetary Interiors, v. 54, p. 258-312

\section{Appendix 2. Analysis of Ground Motion Prediction Equations}

\section{By Melanie Walling}

The performance of the three ground motion prediction equations (GMPEs) was evaluated as a step toward setting the epistemic weights on the GMPE branches of the logic tree in the probabilistic seismic-hazard assessment of the Samoa Island region. The ground-motion data available for this performance evaluation is sparse in event recording, meaning that no event was recorded more than once. A description of the ground-motion records is given in Analysis of Ground Motion Prediction Equations and this appendix is intended to clarify how the ground motion residuals were calculated. The criteria for selecting usable data was ground-motion records recorded within the approximate cutoff distance of the three GMPEs considered, which was rupture distances less than approximately $300 \mathrm{~km}$. This reduced the data set to 72 horizontal-component response spectra recorded by 8 stations. Six stations (ADK, AFI, GUMO, RAO, HNR, and TATO) had six or more recordings; two stations (DAV and PET) had only one record. Of the eight stations, AFI recorded the greatest number of events: 17.

The performance measures that were assessed to evaluate the GMPEs' performances were the accurate prediction of ground-motion amplitude fall off in both magnitude and distance. An analysis of residuals was performed to evaluate each measure. The procedure followed in this Open-File Report to analyze the residuals was similar to other procedures commonly performed in ground motion residual analysis that first eliminate correlations within the residuals before performing the evaluation on the residual terms. These correlations are the correlations created from having unevenly sampled data in source and in station, in both space and time. This appendix describes the approach that was taken to eliminate the correlations within the residuals that was performed prior to evaluating the performance of each GMPE.

\section{Approach}

In most applications of ground motion residual analyses, the correlations of the ground motion caused by unevenly sampled data are addressed by either performing a random effects regression analysis (Abrahamson \& Youngs, 1992) or its equivalent: a two-staged regression analysis (Brillinger and Preisler, 1985; Joyner and Boore, 1993). In both cases, the residuals are separated into the explainable, or fixed effects, and the unexplainable, or random effects. These effects are estimated by fitting the residuals to the following linear model:

$$
\operatorname{Resid}=y-\bar{y}=\eta_{i}+\xi_{i j}
$$


where,

Resid is the total residual,

$y$ is the data,

$y b a r$, is the ground motion prediction model,

$\eta_{i}$ is inter-event term, which is the explained effect estimated in the regression, and

$i$ is the source index;

$\xi_{i j}$, is the intra-event residual, or unexplained, or random effect, and

$j$ is the station index.

When the ground motion data set has many recording per earthquake, $\eta_{i}$ approximates the average source-effects for a given event.

In comparison to the approach just described, the correlation within the residuals from the Pacific Island Arch sparse ground motion data set were addressed differently by performing a randomeffects regression on the total residuals using the following linear model:

$$
\text { Resid }=C_{1}+\eta_{i}+\xi_{i j}
$$

where,

$C_{l}$ is a constant term estimated in the regression,

$i$ is now the site index, and

$j$ is the source index.

Equation (2-2) is different than (2-1) because it includes a constant term, $\mathrm{C}_{1}$, to account for any systematic difference between the overall mean of the selected data and the data set used by the GMPE. The equations also differ because, in (2-2), $i$ is the site index instead of the source index. This means that $\eta_{i}$ now approximates the average station effect and is described as a station term, where before it approximated the average source effect. This makes the intra-event term, $\xi_{i j}$, uncorrelated-in-stationeffects or single station residuals.

Figure 2-1 illustrates the importance of estimating $\mathrm{C}_{1}$ prior to performing the residual analysis by plotting the total residuals at $1 \mathrm{~Hz}$ for Zhao and others (2006) versus magnitude $(1 A)$ and closest distance to fault (1B). In frames $A$ and $B$, the positive offset of the residuals is approximately equal to 0.2 ln units; this means that the Zhao and others (2006) GMPE is systematically under-predicting the ground motion of the selected data set by $0.2 \mathrm{ln}$ units. We interpret this systematic difference as a regional bias term, which can be addressed as an additional source of epistemic uncertainty that gets handled by the logic tree. Describing this offset as a regional bias seems appropriate given that Zhao and others' (2006) data set was primarily composed of recordings from Japanese events, not of ground motions recorded throughout the Pacific Arc Island region.

Figure 2-1 illustrates the importance of estimating the station terms prior to performing the residual analysis by plotting the residuals at ADK station versus magnitude $(2 A)$ and distance $(2 B)$. The residuals shown here are the residuals after $\mathrm{C}_{1}$ was subtracted. In frames $A$ and $B$, the residuals are negatively offset. The station term for $\mathrm{ADK}$ is equal to -0.4 and is approximately equal to the average residual at ADK. This suggests that the site response at station ADK is either less than the site response effect predicted by the Zhao and others (2006) rock equation or that ADK station is not on the same rock type. Once the average station effects were removed from the data by subtracting off the station terms, the single-station residuals were next evaluated for any residual effects. Figure 3 is a plot of the single-station residuals versus magnitude $(3 A)$ and distance $(3 B)$. In both these two frames, the residuals are now centered around zero.

An alternative method to estimate the station terms using the random-effects regression is to directly remove the correlations using a known site-response function for each station and then subtract 
it from each record. The advantage to this approach is that it uses empirical site-response data, which addresses the problem more directly. However, we do not have this information; therefore, the randomeffects approach was applied to estimate the station terms.

\section{References Cited}

Abrahamson, N.A., and Youngs, R.R., 1992, A stable algorithm for regression analyses using the random effects model: Bulletin of the Seismological Society of America, v. 82, p. 505-510.

Brillinger, D.R., and Preisler, H.K., 1985, Further analysis of the Joyner-Boore attenuation data:

Bulletin of the Seismological Society of America, v. 75, p. 611-614.

Joyner, W.B., and Boore, D.M., 1993, Methods for regression analysis of strong-motion data: Bulletin of the Seismological Society of America, v. 83, p. 469-487.

Zhao, J.X., Zhang, J., Asano, A., Ohno, Y., Oouchi, T., Takahashi, T., Ogawa, H., Iridura, K., Thio, H. K., Somerville, P.G., Fukushima, Y., and Fukushima, Y., 2006, Attenuation relations of strong ground motion in Japan using site classification based on predominant period: Bulletin of the Seismological Society of America, v. 96, p. 898-913.

$A$

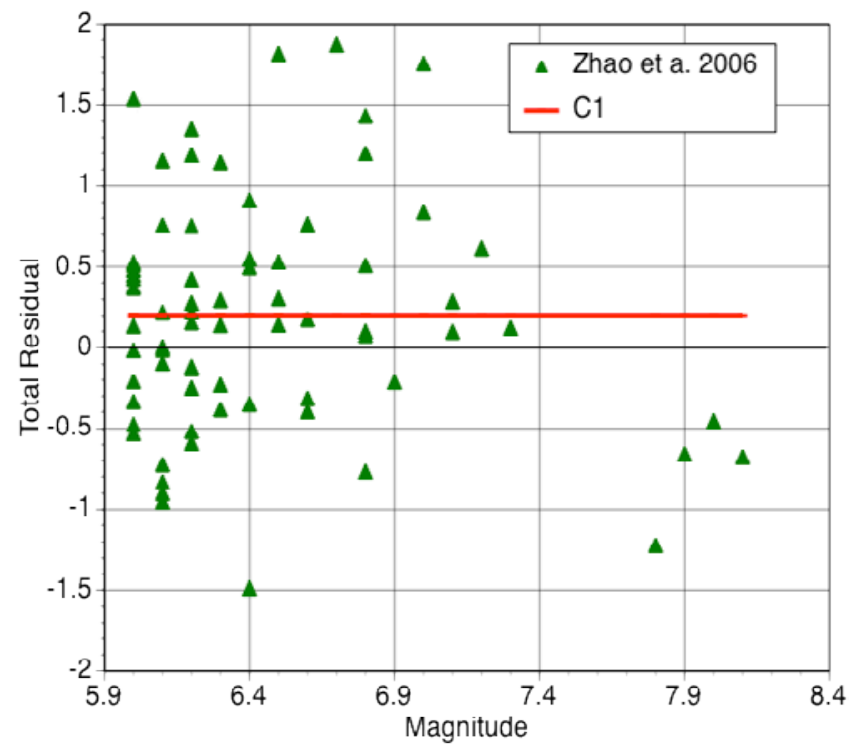

$B$

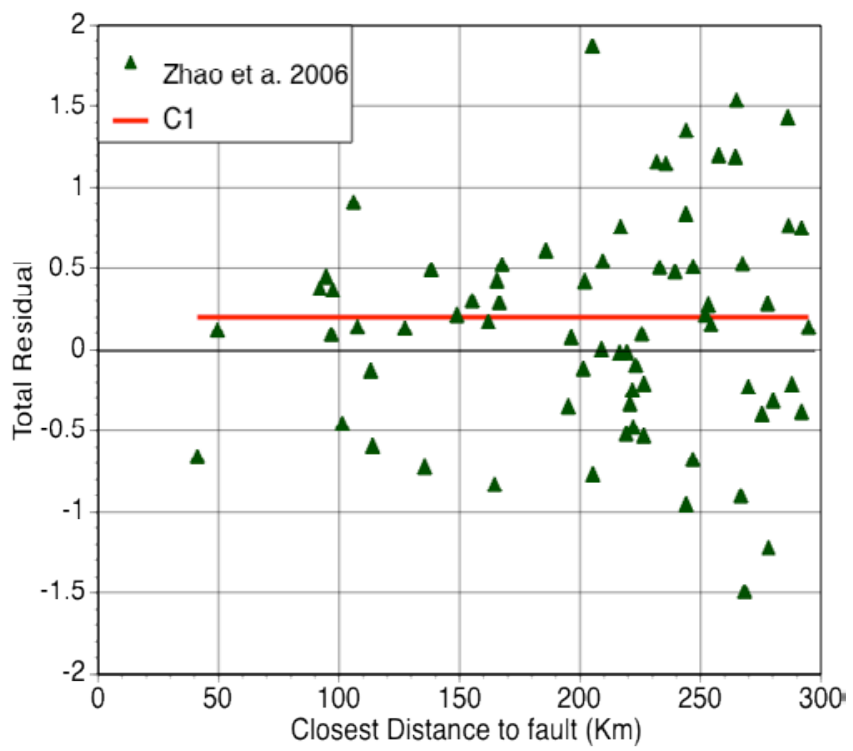

Figure 2-1. The total residuals computed using the selected data set vs. $A$ magnitude and $B$ distance. The red line is the average offset of the total residuals. The positive offset trend means that, on average, the Zhao and others (2006) ground motion prediction equation (GMPE) is under-predicting the ground motions within the Pacific Arc Island sparse data set. This offset is treated as a regional bias effect between the selected data set and the data set used in the Zhao and others' (2006) GMPE and is later removed from the total residuals. (km, kilometers) 
$A$

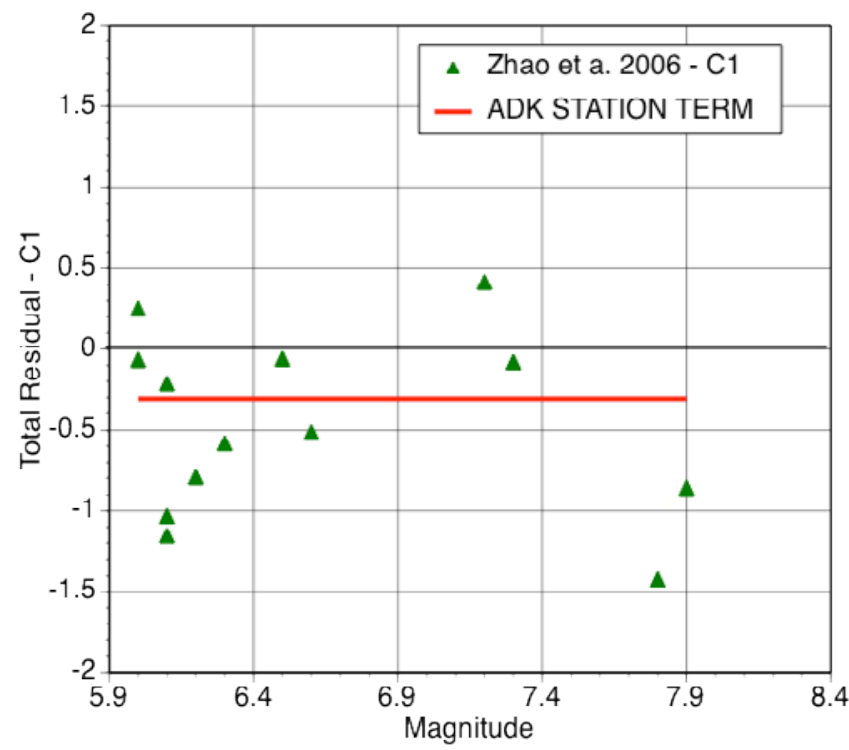

B

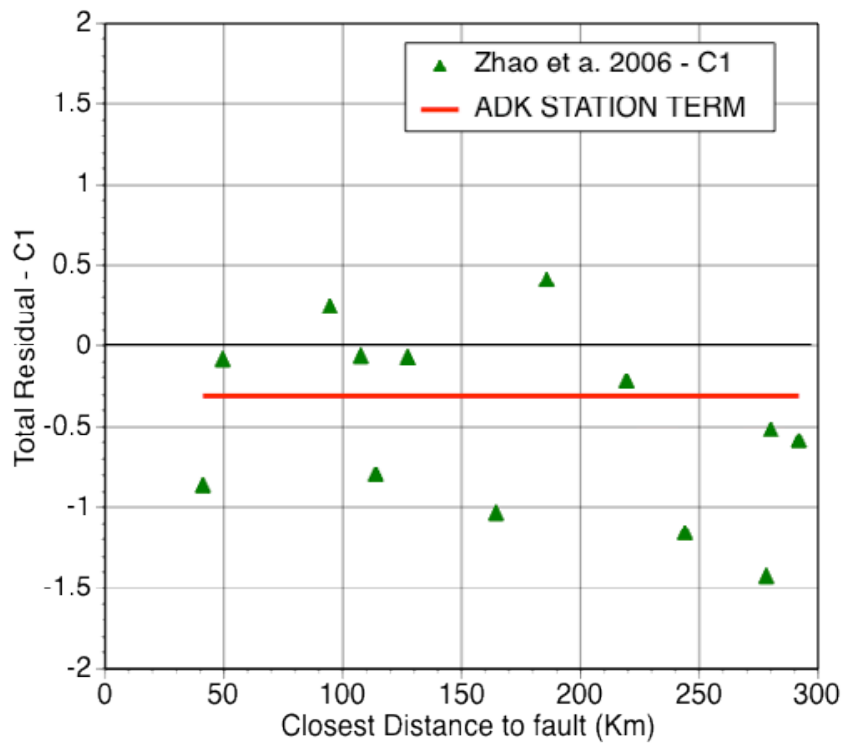

Figure 2-2. The $A D K$ station residual terms calculated by subtracting $C_{1}$ term from the total residual vs. $A$ magnitude and $B$ distance. The red line is the ADK station term estimated by performing the random effects regression using Eqn 2. The station terms approximate the average station effect. The station term is later subtracted from the residuals shown as triangles to calculate the single station residuals. (km, kilometers)

$A$

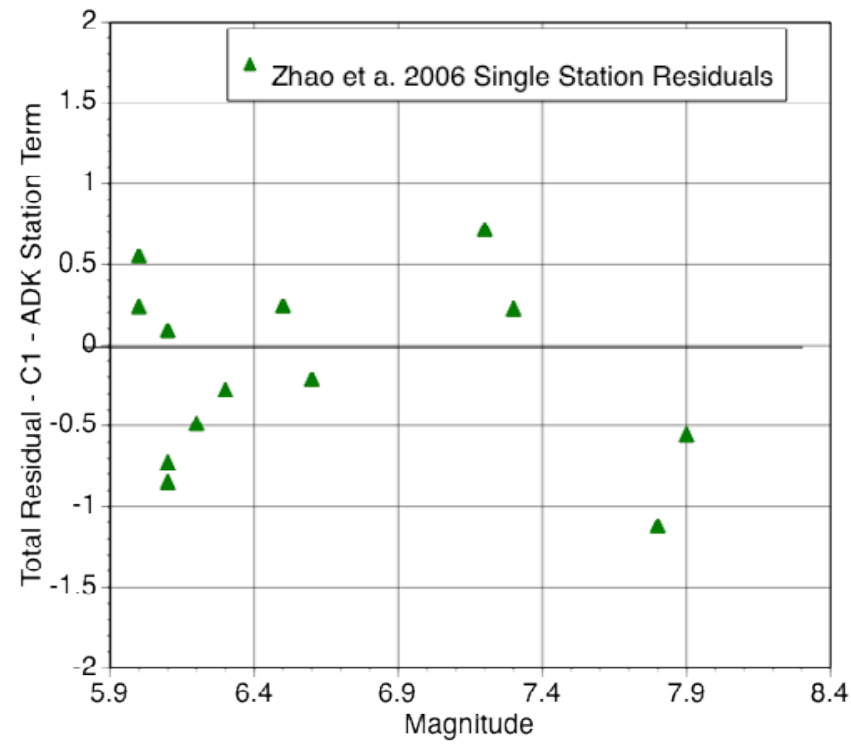

$B$

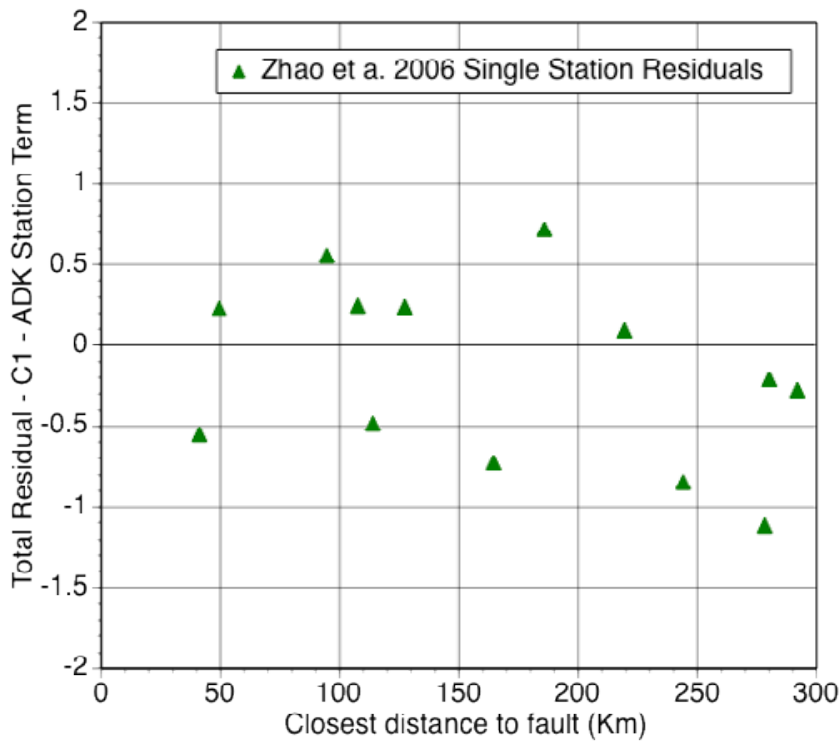

Figure 2-3. The $A D K$ single-station residuals equal to the total residual - $C_{1}-A D K$ station term vs. $A$, magnitude and $B$, distance. The single-station residuals are uncorrelated in station effects and are centered near zero. The residual analysis for evaluating the performance of each GMPE is done using the single-station residuals. 